Slavistische Beiträge · Band 432

(eBook - Digi20-Retro)

\title{
Olga Mladenova
}

\section{Russian Second-Language Textbooks and ldentity in the Universe of Discourse} A Contribution to Macropragmatics

Verlag Otto Sagner München · Berlin · Washington D.C.

Digitalisiert im Rahmen der Kooperation mit dem DFG-Projekt „Digi20“

der Bayerischen Staatsbibliothek, München. OCR-Bearbeitung und Erstellung des eBooks durch den Verlag Otto Sagner:

http://verlag.kubon-sagner.de

( $)$ bei Verlag Otto Sagner. Eine Verwertung oder Weitergabe der Texte und Abbildungen, insbesondere durch Vervielfältigung, ist ohne vorherige schriftliche Genehmigung des Verlages unzulässig. 


\title{
SLAVISTISCHE BEITRÄGE
}

\author{
Herausgegeben von \\ Peter Rehder
}

\author{
Beirat: \\ Tilman Berger • Walter Breu • Johanna Renate Döring-Smirnov \\ Walter Koschmal • Ulrich Schweier • Miloš Sedmidubský • Klaus Steinke
}

BAND 432

\section{VERLAG OTTO SAGNER MÜNCHEN 2004}


Olga Mladenova

Russian Second-Language Textbooks and Identity in the Universe of Discourse

A Contribution to Macropragmatics

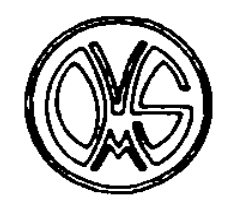

VERLAG OTTO SAGNER MÜNCHEN 2004 


\section{PVA \\ 2004. \\ 1143}

ISBN 3-87690-881-7

(1) Verlag Otto Sagner, München 2004 Abteilung der Firma Kubon \& Sagner D-80328 München

Gedrucks auf alterungsbeständigem Papier

\section{Bayerische \\ Staatsbibliothek \\ München}




\section{Table of Contents}

Foreword

I. Preliminary Considerations: Language and Identity

II. Typology of Second-Language Textbooks

III. Second-Language Textbooks as a Discursive Formation

IV. Authors between Anonymity and Authority

V. Identity and Second-Language Textbooks

VI. In the Field of Concomitance: Valuable Wholes and Their Symbolic Components

VII. 'I' and 'We': Private vs. Public

VIII. A Bird's-Eye View

Index

Illustrations 







\section{Foreword}

In the examination of language. one must suspend, not only the point of view of the 'signified' (we are used to this by now). but also that of the 'signifier', and so reveal the fact that. here and there, in relation to possible domains of objects and subjects. in relation to other possible formulations and re-uses. there is language. (Foucault 1972a, 111)

This study is the outcome of my fascination with Russian second-language textbooks as artefacts of culture, a fascination prompted by the beginning of my teaching career in 1996. Its first version, quite modest in scope, was written in 1997. Being an exploration of the research potential on the macro level of the language-culture interface, it was later incorporated in my SSHRCC-sponsored project, entitled Shared Mental Representations and Language Patterns: Research Strategies and Empirical Studies.

I would like to express my gratitude to the Social Sciences and Humanities Research Council of Canada for its generous support of my research. All work on this study was done under the aegis of the Language Research Centre at the Faculty of Humanities at the University of Calgary. I am indebted to my colleagues at the University of Calgary for their goodwill and constant interest in my research in the area of Russian second-language textbooks.

So, what is this book about? It is an overview of the modifications and interaction of two discursive formations (the Second Language Learning and the Identity discursive formations) over four centuries of Russian history. The theory I lean on comes from various sources, the most important of which are Michel Foucault's discourse analysis, Roman Jakobson's framework of the communicative act, semiotics and semantic analysis. The blend is my own. It allows me to compose a three-dimensional explanatory model in which smallscale linguistic detail is combined harmoniously with larger-scale language units 
viii

to illuminate matters of cultural importance in their linguistic guise. It makes it possible to analyse images and narratives in a homogeneous manner. Compositionally, interdisciplinarity pours into a non-linear narrative, which follows a spiral that redefines on a higher level and in a different setting distinctions first discovered on a lower level with the theoretical devices of other disciplines. The lower coil of the helix accommodates the complementary argumentations of anthropology and lexical semantics, while the higher one brings the conclusions to the plane of discourse analysis and semiotics.

Chapter I discusses the views of Russian speakers on the Self/Other opposition in terms of ethnicity, citizenship and language, and places Russian second-language textbooks in the framework of verbal communication. It then explores the relevance of the alternative perspectives on Self for second-language textbooks as acts of communication.

Chapter 2 offers a typology of second-language textbooks according to anthropological criteria: for instance, the author's vantage point, desire to provide authentic cultural information and awareness of the legitimacy of cultural diversity; the availability of cross-cultural comparison; and the imagined relationship between Self and Other. An extra discursive dimension is added to this typology in the course of the book.

Chapter 3 argues that the network of Russian second-language textbooks in their broad functional definition reflects in writing the existence of a discursive formation, the Second Language Learning (SLL) discursive formation. Since its inception at the end of the seventeenth century, the SLL discursive formation has passed through two stages characterized by numerous distinctions on different levels: a premodem one (up until the 1870s) and a modern one (ever since).

Chapter 4 looks at the sources from which textbook authors derive their authority, such as (native) fluency in the target language, the institutional sites with which authors associate and their method for teaching language. In view of the twin objects of the SLL discursive formation (a language and its speaking subject), authors can also lean on standard grammars of the target language and 
samples produced by different categories of speaking subjects of that language. The existence of partial overlap (a field of concomitance) is established between the SLL discursive formation and two adjacent discursive formations: the Linguistic discursive formation (through the intermediary of the standard grammars of the target language) and the Identity discursive formation (through the intermediary of the speaking subject).

Chapter 5 views the second-language textbook as a message and identifies the area in which the overlap between the SLL and the Identity discursive formation manifests. It also characterizes discursively the types of textbooks in which there is no such overlap. Then it surveys the coherent subdivisions of the Identity discursive formation (identity discourses) available in second-language textbooks in their relationship to the range of identity discourses produced in Russian society. This chapter looks at the three stages through which the Identity discursive formation passes: premodem, modem and postmodern, defined discursively as the stages of silence, monologue and dialogue, respectively.

Chapter 6 postulates that identity discourses place value on the wholes that form their basis because identity is affiliation of Self with Self's "own" whole defined in terms of time and space, an affiliation shared with other people. It then proceeds to explore the discourse-specific syntagmatic chains of concepts referring to the events in which the relevant group of people has participated over time in its territory, as well as the paradigms of symbols that coordinate discourses inside the Identity discursive formation. Valuable wholes are presented in textbooks either directly or through their metonymic and metaphorical summarizing symbols. The choice of presentation serves as a discursive marker that distinguishes between textbook types.

And finally, chapter 7 introduces the interrelated oppositions of group vs. individual, on one hand, and public vs. private, on the other, in the format peculiar to the SLL discursive formation. These oppositions also serve to delimit a last remaining type of textbook and add an extra criterion for the contrast among identity discourses. 
I have made every effort to preserve the authenticity of Russian culture in my English-language presentation. This is the reason for the extensive quotations that give a taste of the kind of data that have served as the basis for my analysis. All citations are preserved in the language of the original. If that language was not English, the quotations are supplied with an English translation. English translations are mine unless stated otherwise in the text.

Russian and occasional Greek language data have been transliterated according to the system in general use among linguists. The spelling of pre-1918 texts in modem Russian (defined as the Russian language since A. S. Puškin) has been modernized in conformity with the standard practice in Slavic studies. Earlier Russian texts were transcribed according to the following conventions. Accents and other diacritics were omitted. The letters of the Cyrillic alphabet were rendered in the same way as for the modern period with the following exceptions: $b$ was transliterated as [ü], $b$ as [ī], $\omega$ and $o$ as [o], $\mathbf{a}$ as [ja], $b$ as [é], oy and $\boldsymbol{\gamma}$ as $[u]$, и and $\bar{i}$ as [i]. For the sake of consistency, Russian personal names (with the exception of several names of monarchs) have been rendered in the text in transliteration. 


\section{Preliminary Considerations: Language and Identity}

A society can have two alternative perceptions of its own culture and language: it can either see them as 'the natural culture and language of a human being' or as equal members of the interconnected sets 'human languages' and 'human cultures'. The former self-centred perspective prevailed in previous ages: it is also characteristic of the so-called great nations or of nations living in cultural isolation. To give only a couple of examples, the ancient Greeks perceived all non-Greeks, Romans included, as bárbaroi 'barbarians'.' Instead of reacting against this label, the Romans remained under the strong impression of the Greek cultural superiority even after they had conquered Hellas politically in 146 B.C.E. ${ }^{2}$ Mainstream ethnicity in North America is perceived as zero ethnicity or as the absence of ethnicity (Greenhill 1994). Muscovy, especially during the heyday of the doctrine "Moscow as the third Rome", was certainly another instance of a society of this type (Fedotov 1967, 260-262); note Vasilij Fedorov Burcev's afterword to the first Russian primer published in 1634:

nevěrnii jazyci $\ldots$ otū pravago puti otstupiša $i$ sv. kreščenija $i$ apostol'skago učenija ne prijaša, no vǔ slědũ čjuždixŭ bogovŭ poidoša, $i$ sami sebě zakony, i obyčaja i gramoty izložiša; inii že otŭ eretikǔ naǔ̌eni byša. i božestvennoc pisanie razvratiša, togo radi i do dnesī, jako vo tmě nevěděnija xodjatũ. Našŭ že xristijanskij rodũ pomilova Gospodĩ svoeju

\footnotetext{
'See for instance Plato. The Statesmam. 262 D and Strabo. Geography 14.2.28 for confirmation of the existence of this view (considered erroneous by both authors) as well as for Strabo's attempt to explain it as a consequence of the negative evaluation of foreign accent by native speakers of Greek.

2 The Roman playwright Plautus. who died around 184 B.C.E., alludes in his comedy Miles Gloriosus. 211 to the Roman poet Naevius as barbarus. As this word comes out of the mouth of his character Periplectomenus. an old gentleman of Ephesus, it means perhaps no more than awareness of the Greek point of view. Later Roman authors of the first century B.C.E. and the first century C.E. (such as Cicero. Seneca. Pliny and Quintilianus) grouped Greeks and Romans together and opposed them to barbari. The Greek loanword and its narrowed reference demonstrate that Romans had assimilated the Greek point of view and adapted it to their situation.
} 
milostiju i počte nasū slavoju i čestiju, pače vsěxū jazykū, ašče prežde i jazyci běxomũ, no ego, tvorca našego i vladyki vsěxū, paki pomilovani byxomŭ $i$ spodobixomsja otŭ nego istinnomu bogorazumiju i prijaxomŭ sěmja blagočestija. (Pekarskij 1862, I, 168-9)

'The faithless heathen nations stepped away from the right road and did not adopt the holy baptism and the apostolic doctrine but followed foreign gods and invented for themselves laws and customs and literacy; others were taught by heretics and comupted the divine scriptures and that is why they remain until this day in the dark of ignorance. But God showed to our Christian folk his mercy and granted us glory and honour more than to any heathen nation. Although we too used to be heathen, we were graced by him, our creator and the ruler of everything, and received from him true understanding of God and the seed of piety.'

This quotation pinpoints religion as the most important criterion for the fleshing out of the opposition between Self and Other. Responsibility for the negative perception of foreign Christian customs in this period lies with the dogmatic disagreement between the Orthodox Church and other Christian denominations. It was not. however, the only period of this kind in Russian history. Linguistic evidence points to the possibility of earlier, pre-Christian roots of the self-centred perspective. The ethnonym russkij 'Russian', a derivative of the feminine collective Rus (Vasmer 1986-1987, 3:521), which could denote both Russians as a group and the territory inhabited by them, testifies that at the time when it originated. speakers of Russian saw themselves as different from other ethnic groups: all other ethnonyms in Russian are nouns, the only substantivized adjective being russkij, which stands for russkij celovek 'Russian person ${ }^{3}$ The conclusion one can draw is that for a long time Russians needed no label for Self because celovek with no further attributes referred automatically to a Russian person. On the rare occasions when one needed to refer to the ethnic identity of Self explicitly, one would use russkij celovek. Other people, however. were seen as a deviation from the description of a normal person, and they

\footnotetext{
${ }^{3}$ Potebnja mentions a similar use of other adjectives such as pol 'skij 'Polish' for 'Pole'. aglea ${ }^{\circ} k o j$ 'English' for 'Englishman" in the ulder period of Russian or the Russian dialects (Potebnja 1968. 42).
} 
received deservedly various terms to denote them. ${ }^{4}$ Such a self-centred identity lies behind ethnonyms for Self with motivation 'people; real people' attested in societies around the globe. Among examples are labels for Self like Dene 'people', Inuit 'people', Mari 'man', Nenets 'man, person', Deutsch 'folk, people' and many others (Kljukov 1984). Conferring a terminological status to a regular noun that meant initially 'person(s)', such labels make it possible for the ethnic group to move from a self-centred to an egalitarian model of Self. By the same token, they constitute evidence of a previous state of affairs marked with the absence of self-denomination, which is typologically identical to that described here for Russian.

One can assume that the self-centred model, justified first in ethnic and later in religious terms, prevailed in the early period of Russian history delimited at the upper end by the establishment of close and regular cultural contacts between Russia and the outside world in the seventeenth century. Its relics are traceable in folklore until a much later time (Belova 1999). In its mythological stage, the characteristics of the ethnic and religious Other are simultaneously markers of non-human nature, or at the very least, abnormality. Foreign speech is, for instance, alternatively equated to muteness, animal communication or swearing. Perhaps this view is easiest to understand in the religious domain, where adherence to other confessions is still perceived by many religious people across the globe as impure, as it was in the framework of the self-centred model of Self and Other.

Another and much later Russian label subscribing to a poeticized version of this perspective is connected with the word family of vsećelovek 'universal human being', vsećelovečeskij adj. 'referring to universal humanity; belonging to the entire human race' and vsečelovečnost 'universal humanity; representation of the entire humankind' < vse 'all' + celovek 'human being', defined by Berdjaev thus:

\footnotetext{
The appearance of an ethnic self-denomination can lag behind the consolidation of the ethnic
} 
(1) Vsečelovečnost' ne imeet ničego obščego s internacionalizmom, vsečelovečnost' est' vysšaja polnota vsego nacional'nogo. (BKSO: Berdjaev, N. A. [1918])

'Universal humanity has nothing in common with internationalism; it is the utmost plenitude of everything national.'

Not coincidentally, vsečelovečnost' is seen as a characteristic of the perfect

Russian. In other words, the ideal Russian person can stand for the entire human race:

(2) My uže možem ukazat' na Puškina, na vsemimost' i vsečelovečnost' ego genija. Ved' mog že on vmestit' čužie genii $v$ duše svoej, kak rodnye. (BKSO: Dostoevskij, F. M. [1880])

'We can already point at Puškin, at the global and universally human quality of his genius. After all, he succeeded to find room in his soul for other national geniuses as if they were congenial.'

(3) On [sc. Puškin] ukazal nam put' k tomu, čtoby russkij jazyk stal jazykom mira, jazykom vsečelovečeskim, tak že, kak tvorimye našim narodom formy stali primerom i dostojaniem vsego celovečestva. (BKSO: Tolstoj, A. N. [1953])

'He [Puškin] showed us how Russian can become a global language, a language of universal humanity, in the same way in which the forms created by our nation became an example and a cherished possession for the entire humankind.'

Vsecelovek and kosmopolit "cosmopolitan; a person free from national attachments', two labels promoting altemative scripts of behaviour, are opposed to the human being with a salient national identity of the egalitarian typc, called in the following quotation prosto celovek 'simply a human bcing':

(4) Xorošo ob ètom skazal kogda-to D. N. Mamin-Sibirjak [...]: "Vremja ljudejkosmopolitov i vsečelovekov minovalo. nužno byt' prosto čelovekom, kotoryj ne zabyvaet svoej sem'i, ljubit svoju rodinu i rabotaet dlja svoego otečestva." (BKSO: Bogoljubov, K. [1954])

group. as etymologists can prove (Trubacev 1985. 3-4). 
'D. N. Mamin-Sibirjak expressed this well a long time ago [...]: "The time of cosmopolitans and universal human beings is up. Now one ought to be simply a human being who does not forget one's family, loves one's homeland and toils for one's fatherland."'

As opposed to the self-centred perspective of Self that claims a universal status, the alternative egalitarian perspective is much more common but not unproblematic either. Since cultural and linguistic areals seldom coincide with state borders, languages and societies (and Russian in particular) are divided from other languages and societies not by a clear-cut boundary but by a cluster of boundaries. Table 1 displays the egalitarian perspective on language, society and culture in Russia in their nineteenth-and twentieth-century linguistic guise.

\begin{tabular}{|l|l|l|l|l|l|l|}
\hline \multicolumn{2}{|l|}{} & $\begin{array}{l}\text { Native } \\
\text { speakers } \\
\text { of } \\
\text { Russian }\end{array}$ & $\begin{array}{l}\text { Natives of } \\
\text { Russia } \\
\text { (First-hand } \\
\text { experience } \\
\text { with } \\
\text { Russian } \\
\text { social } \\
\text { reality) }\end{array}$ & $\begin{array}{l}\text { Russian terms } \\
\text { citizenship }\end{array}$ & $\begin{array}{l}\text { Mixed } \\
\text { classification }\end{array}$ & $\begin{array}{l}\text { By } \\
\text { ethnic } \\
\text { identity }\end{array}$ \\
\hline 1 & $\begin{array}{l}\text { Russian } \\
\text { citizens of } \\
\text { Russia }\end{array}$ & + & + & rossijanin & russkij & russkij \\
\hline 2 & $\begin{array}{l}\text { Non- } \\
\text { Russian } \\
\text { citizens of } \\
\text { Russia }\end{array}$ & - & + & & $\begin{array}{l}\text { inorodec / } \\
\text { nacmen }\end{array}$ & nerusskij \\
\hline 3 & $\begin{array}{l}\text { Non- } \\
\text { Russians } \\
\text { abroad }\end{array}$ & - & - & inostranec & inostranec & \\
\hline 4 & $\begin{array}{l}\text { (Second- } \\
\text { generation) } \\
\text { Russian } \\
\text { emigrés }\end{array}$ & + & - & & $\begin{array}{l}\text { russkij (?)/ } \\
\text { inostranec } \\
\text { (?) }\end{array}$ & russkij \\
\hline
\end{tabular}

Table 1. Self and Other

During the Soviet period of Russian history rossijanin, a derivative from the relatively recent Rossija 'Russia' and attested since 1516 (Vasmer 19861987. 3:505), officially counted as an obsolete synonym of russkij (Ožegov 1984. 
609). The following example shows that russkaja ženščina 'Russian woman' and rossijanka could indeed be used as synonyms:

(5) Jasno, cto k sozdaniju takogo muzeja nado privlekat' ne tol'ko mestnuju intelligenciju, a vsex rossijan, kol' zadumali rasskazat' o slave russkoj żenšiny. Ja gotov poklonit'sja tomu čeloveku, kotoromu prišla mysl' vosslavit' rossijanku! (BKSO: Vasil'ev, I. [1986])

'It is clear that not only the local intelligentsia but all people of Russia [rossijane] should be involved in the creation of such a museum, if the objective is to depict the glory of the Russian woman [russkaja żensičina]. I am ready to bow to the person whose idea it was to glorify the women of Russia [rossijanka].'

On the other hand, during the same period the explicit contrast of russkij and rossijanin was also current:

(6) Narodnyj poèt Baškirii Mustaj Karim v odnom iz svoix stixotvorenij govorit: “Ne russkij ja. no - rossijanin!" (BKSO: Sobolev, L. S. [1965])

'The national poet of Bashkiria Mustaj Karim says in one of his poems: "I am not Russian [russkij], but I am a citizen of Russia [rossijanin]!"'

People who perceive rossijanin as a synonym of russkij root their perspective in the Imperial period, during which it supposedly was a fancy word for the East Slavic population of the empire (that is, Russians, Ukrainians and Belorussians), and disagree with its contemporary usage as a designation of any citizen of Russia regardless of ethnic background because for them such a usage has an artificial inkling (Duličcnko 1999, 250: Russkij vestnik, 1992, No. 49-52, p. 2). The contemporary Russian opposition of russkij and rossijanin parallels that of Englishman and British. Perhaps rossijanin and the other derivatives from Rossija always presented speakers with the possibility of a double interpretation, a situation fitting with the alleged Polish inspiration of rossijskij and rossijanin (Dal' 1880-1882, 4:114). Polish rosyjski continues to be the only equivalent of both Russian russskij and rossijskij. Its derivative rosyjskosic 'Russianness' can be used along with dcrivatives from other ethnonyms: for example, niemieckośc 
Goethego, rosyjskość Tolstoja, polskość Mickiewicza 'the Germanness of Goethe, the Russianness of Tolstoj, the Polishness of Mickiewicz' (Doroszewski 1965, 1051-1052). The Russian adjective rossijskij was systematically used in the meaning of russkij in collocations with grammatika 'grammar', dialect 'dialect', razgovory 'dialogues' and 'jazyk 'language', as one can see in GMRF 1724, RG 1750, NRG 1788, NDRG 1792, UR 1795, ORTPG 1825, RRG 1827, PGRL 1827, GTJa 1835, SRPJa 1838. It entered into competition with russkij in these collocations only in the 1830s (see OPUK 1835, NORJa 1839, PKRJa 1847, RX 1848 , etc.) and was eventually ousted altogether by it.

In its broader meaning 'citizen of Russia', rossijanin was replaced during the Soviet period with sovetskij celovek, which was to be downgraded to the pejorative sovok in the late Soviet and post-Soviet periods (Mokienko \& Nikitina 1998, 564). The shift from rossijanin to sovetskij čelovek and back to rossijanin involves more than a simple change of label; it also marks a transformation in the corresponding identity, as we can see if we compare the occurrences of nastojaščij rossijanin with nastojašcij sovetskij čelovek, collocations containing the hedge nasıojaščij 'true, authentic, real'. Hedges, in George Lakoff's terminology, are words "whose meaning implicitly involves fuzziness" and "whose job is to make things fuzzier or less fuzzy" (Lakoff 1973, 471). The function of nastojaščij is to delimit a hard core of typical members of the category. It becomes obvious that this hard core is different in every case and that different actions and features are compatible with membership in that core. I shall give only one example in which the replacement of nastojaścij sovetskij čelovek with nastojašcij rossijanin would make the whole conversation meaningless. A police officer is talking to a schoolboy:

(7) Voprosy majora menja glavnym obrazom smešili, naprimer, takoj: "Vy sčitaete G. nastojašcim sovetskim čelovekom?" - "Da, sčitaju." - "A vy znaete, čto $v$ prošlom godu on izrezal kryšku party? Možet tak postupat' nastojaščij sovetskij celovek?" Poskol'ku i kryšku, i siden'e, i spinku sobstvennoj party slučalos' rezat' i mne, ja zasmejalsja. (Nikolaj Rabotnov, Sorokovka. Znamja 2000, Nr. 7. Electronic version: 
<magazines.nuss.ru/znamia/2000/7/>)

'The Major's questions mostly made me laugh, for instance such a question: "Do you consider G. a real Soviet person?" - "Yes, I do." - "And do you know that last year he whittled the panel of his desk down? May a real Soviet person do such a thing?" I started laughing, as I had occasionally also cut up the panel, the seat and the back of my own desk.'

Ethnic Russians have always been designated by the term russkij. The subset nastojaščij russkij čelovek differs from both the subsets nastojašc̆ij rossijanin and nastojašcij sovetskij čelovek. Some typical features are listed in the following example:

(8) Tarkovskij - nastojaščij russkij celovek, umnyj, sil'nyj, tonko organizovannyj, krasivyj, a samoe glavnoe - dobryj! (Igor' Jarkevič, Cernoe znamja izmeny, <guelman.ru/yark.h(m>)

'[A. A.] Tarkovskij is an authentic Russian person: smant, strong, subtle, comely, and. most importantly, kind!'

The antonym of russkij is nerusskij. The following sentences illustrate the use of nerusskij as an adjective and a noun. Examples (9) and (10) show the use of nerusskij to refer to people. All the other sentences associate nerusskij with language, either directly, as in (11), (12) and (13), or indirectly, as in (14). Even these few examples can convey the significance of the language criterion for the russkij/nerusskij opposition:

(9) O tom, kak neravnomerno raspredelen po selenijam nerusskij èlement, mne uže prixodilos' upominat'. (BKSO: C'exov, A. P. Ostrov Saxalin, XV)

'I have already had the chance to mention how uneven the distribution of the non-Russian element in the localities is.'

(10) - A èto - žena tvoja? Cyganočka, čto li? Nerusskaja? (BKSO: Bondarev, Ju. V. [1967])

'And this... Is this your wife? Is she perhaps Gipsy? Non-Russian?'

(11) - Ty kto, slušaj, budeš'? - vyzyvajušče sprosil on Suxova zvučnym, nerusskogo tona golosom, $v$ kotorom slyšalsja legkij južnyj akcent. Tak 
govorjat russkie, mnogo let proživšie na Kavkaze i perenjavšie i tamošnij lad reči i tamošnie uxvatki. (BKSO: Pavlenko, P. A. [1953])

"'Listen, who might you be?" he asked Suxov provocatively in a resounding voice of a non-Russian tone, in which one could discem a slight southem accent. That is how Russians talk who have lived in the Caucasus for a long time and borrowed the local manner of speaking and behaviour.'

(12) - Il’ja Konstantinovitššs! - ot staratel'nosti u nee daže vygovor stal kakoj-to nenusskij, pribaltijskij, čto li. (BKSO: Baklanov, G. Ja. [1982])

“"Il'ja Konstantinovitššs!" Out of diligence her pronunciation became kind of non-Russian, who knows, perhaps Baltic.'

(13) Vdrug menja oklikaet Abramovic-Blek. Russkij dvorjanin s nerusskoj, da ešče dvojnoj familiej, iz oficerov carskogo flota, vypivoxa, fantazer, zabubennaja golova. (BKSO: Štejn, A. [1981])

'All of a sudden I was hailed by Abramovic-Blek. A Russian nobleman with a non-Russian and moreover double sumame, an officer of the Imperial navy who liked his drop, a dreamer and an unruly fellow.'

(14) Kišinev - gorod sovsem nerusskij. Na ulicax sovsem ne slyšno russkogo jazyka - vse židovskij i moldavanskij govor. (BKSO: Garšin, V. M. [1877])

'Kišinev is a completely non-Russian city. One cannot hear Russian in its streets; Jewish and Moldavian speech prevail.'

Foreigners are designated in Russian by the term inostranec, a compound of ino- 'other' and strana 'country'. In other words, inostranec is a person from a country other than Russia. Here are some older dictionary definitions of inostranec: "Ein Ausländer, un étranger" (BKSO: Slovar' Nordsteta 1780); "čužezemec; iz čužoj storony, iz drugogo gosudarstva prišedšij" ‘an alien; [a person] who has come from a foreign land, from another state' (BKSO: Slovar' Akademii 1794); "poddannyj drugogo gosudarstva; čužezemec" "subject of another state; alien' (BKSO: Slovar' Akademii 1847). At the beginning of the tentieth century, a Russian encyclopedia noted the juridical character of the term that in modern societies has more to do with citizenship than with anything else: 
(15) V primitivnyx દeloveč[eskix] ob[క̌cest]vax, gde priznak gosudarstva sovpadaet s plemenn[ymi] i religiozn[ymi] priznakami, ponjatie I[nostranca] opredeljaetsja otsutstviem plem[ennoj] i religiozn[oj] svjazi s ostal'n[ymi] cl[enami] ob[క̌čest]va; $v$ gosudarstvax razvityx, zaključajuščix $v$ sebe različn[ye] narodnosti, ponjatie I[nostranca] stanovitsja otvlečennojuridižeskim i opredeljaetsja priznakom neprinadležnosti k čislu poddannyx. (BKSO: Russkaja énciklopedija 1911)

'In primitive human societies where the state coincides with tribal and religious boundaries, the notion of foreigner is determined by this person's lack of tribal and religious connections with the other members of society; in developed states comprising various ethnic groups, the notion of foreigner becomes a juridical abstraction and denotes exclusion from the group of subjects.'

In consonance with its juridical character, the term is used broadly in laws and decrees: Zapreščenie brakov graždan SSSR $s$ inostrancami 'Prohibition of marriage between citizens of the USSR and foreigners' (BKSO: Sbornik Zakonov SSSR i Ukazov za 1947 g.). Typical usage, as in (16), takes it for granted that ethnic otherness accompanies non-Russian citizenship. Usually ethnic and cultural otherness is obvious, but as (17), shows this need not be the case. Visible or not, otherness is the marker of inostranec:

(16) Vzošedši v gostinuju, ja uvidel neznakomogo そeloveka, kotorogo totčas pocel za inostranca, ibo neskol'ko molodyx ljudej besprestanno vykazyvali emu sebja, besprestanno tormošili ego. $U$ nas svoj maner prinimat' inostrancev, nečto $v$ tom rode, kak slepni prinimajut lošad' $v$ letnij den'. (BKSO: Gercen, A. I. [1954])

'When I entered the drawing room. I saw a stranger, whom I assumed right away to be a foreigner because several young men were constantly showing themselves off to him, constantly pestering him. We have our own way of entertaining foreigners, very similar to the way gadflies entertain a horse on a summer day.'

(17) Každaja stolica voobšče xarakterizuetsja svoim narodom, nabrasyvajuščim na nee pečat' nacional'nosti; na Peterburge že net nikakogo xaraktera: inostrancy, kotorye poselilis' sjuda, obžilis' i vovse ne poxoži na 
inostrancev; a russkie, $v$ svoju očered' ob"inostranilis' i sdelalis' ni tem, ni drugim. (BKSO: Gogol', N. V. [1829])

'Every capital city is characterized with its own population that gives it the imprint of nationality. Only Petersburg has no character: the foreigners who reside here feel at home and are very unlike foreigners, whereas the Russians have acquired some foreign features and look neither like Russians nor like foreigners.'

Of course, this is not always the case, as (18) and (19) demonstrate. These examples show that inostranec is a conventional label that can fit any insider, given free choice of citizenship.

(18) Kto $v$ službu ne popal, primykali $k$ toj, kolyxavšejsja na obe storony rubeža, massy, kotoraja služila moskovskomu pravitel'stvu poka naxodila èto dlja sebja vygodnym, i momental'no prevrašcalas' v "inostrancev" kak tol'ko èta vygoda isčezla. (BKSO: Pokrovskij, M. N. [1922])

'Those who were not taken into service joined the mass swaying on both sides of the border that served the Moscow government while this was profitable for them and turned into "foreigners" the moment advantage vanished.'

(19) Moj svekor-pokojnik, znaete li, britanec po pasportu, xotja rossijanin. Tak ved' čut' ne iz pušek palili. kogda $v$ Piter priezžal. Ljubim my čužezemca, počtitel'ny k inostrancu... (BKSO: Semenov, Ju. S. [1974])

'My late father-in-law was, you know, British by passport although from Russia. Well, they almost fired the cannons when he arrived in Petersburg. We love the alien, we are deferential to the foreigner...'

Ethnic otherness alone is certainly not a sufficient ground to be granted the status of inostranec:

(20) Proeż̌aja Estoniju, uvidel sego molodogo čeloveka, i po blagorodnomu vidu zaključil, čto ne Estlandec, no inostrannoj. (BKSO: Lomonosov, M. V. [1766])

'During my joumey through Estonia I saw this young man and concluded by his noble appearance that he was not Estonian but a foreigner.' 
In the nineteenth century the non-Russian subjects of the Russian empire had the name inorodcy, a compound of ino- 'other' and rod 'extended family, kin group, clan', which by the end of the century had acquired pejorative overtones. The range of meanings of the word and its derivatives as well as their connotations can be seen in the following quotations. (21) shows that by the end of the Imperial period both the narrow and the broad definition were current. The broad meaning in its reference to the entire group is illustrated in (22) and (23). (24) shows the use of the term in its broad meaning to refer to a specific person. (25) displays the term in its early competition with others such as inoverec and jasačnyj. Finally, (26) gives an idea how ethnocentric Russians may have perceived the contrast between russkij and the "boring" inorodec.

(21) Inorodcy, $v$ obšimom smysle nazv[anije] vsex russkix poddannyx, neslavjansk[ogo] proisxoždenija; $v$ bolee tesnom texnič[eskom] smysle nek[otorye] plemena, gl[avnym] obrazom mongol'sk[ie], tjurksk[ie] i fmskie. (BKSO: Russkaja Énciklopedija 1911)

'Inorodcy in the broad meaning is a name for all Russian subjects of nonSlavic descent; in a more technical sense [the term refers to] some groups. mainly Mongolian, Turkic and Finnish.'

(22) Rossija, krome russkago plemeni, naselena cšče mnogimi inorodnymi plemenami. (BKSO: Katkov, M. N. [1864])

'Russia is inhabited by many groups of other ethnic descent besides the Russian group.'

(23) Velikorussov (cdinstvennyx ne "inorodcev") $v$ Rossii ne bolee 43 procentov naselenija. Znacit "inorodcy" $\vee$ bol'šinstve! (BKSO: Lenin. V. I. [1914])

'The Great Russians (the only ones who are not inorodcy) in Russia run to no more than 43 per cent of the population. This means that inorodcy form the majority!' 
(24) Éto byl celovek, čisto govorjaš̌ij po-russki, no v kotorom čuvstvovavlos' čto-to inorodzeskoe: nemec ili latyš. (BKSO: Korolenko, V. G. [1909])

'This was a man speaking Russian without an accent but in whom one could feel something of an inorodec: a German or a Latvian.'

(25) Speranskij sostavil tak nazyvaemyj "Inorodčeskij ustav", kotoryj namečal novuju sistemu upravlenija pokorennymi narodami Sibiri. Sibirskie plemena, ran'Še nazyvavక̌iesja inovercami i jasačnymi, stali nazyvat'sja "inorodcami". Oni byli razdeleny na osedlyx, kočujuščix i brodjačix. "Inorodčeskij ustav" zakrepljal gospodstvujušcee položenie verxuški feodalov i samye otstalye formy byta. (BKSO: Istorija SSSR pod red. Pankratovoj [1953])

'[M. M.] Speranskij [(1772-1839)] compiled the so-called Minority Charter, which was proposing a new system of government over the conquered peoples of Siberia. The Siberian tribes, previously called inovercy "persons of other denomination" and jasačnye "people taxed with the jasak tax", were now renamed inorodcy. They were classified into settled, nomadic and wandering. The Minority Charter consolidated the position of the ruling feudal clique and the most backward forms of daily life.'

(26) Takie pisateli, kak vy, Sergej Vasil'evic, kak Leskov, ne mogut imet' u našej kritiki uspexa, tak kak naši kritiki počti vse čuždy nusskoj korennoj žizni, ee duxa, ee form, ee jumora, soveršenno neponjatnogo dlja nix, i vidjat $v$ russkom celoveke ni bol'še ni men'క̌e kak skučnogo inorodca. (BKSO: Plexanov, S. [1987])

'Such writers like you, Sergej Vasil'evic, or like Leskov, cannot have a good name with our critics because almost all of them are strangers to the authentic Russian life, to its spirit, form and humour, which remain totally incomprehensible for them, so that they see in the Russian person no more and no less than a dull inorodec.'

Early dictionary definitions include the following: inorodec "inoplemennik, cužezemec" "someone from another tribe, someone from an alien country' (BKSO: Slovar' Akademii 1794); "Celovek inogo roda, inoplemennik" 'a person of another descent, of another tribe' (BKSO: Slovar' Akademii 1847). 
It has become obvious that it was not always clear who deserved the name inorodec. More importantly, the ascription appears to be a matter of opinion and differs from person to person:

(27) Šiškov, prezident nikolaevskoj akademii, [...] byl tože russkij, sam arximandrit Fotij, objazannyj Puškinu svoej posmertnoj slavoj, ne prinjal by ego za "inorodca". (BKSO: Leonov, L. M. [1945])

'[A. S.] Šiškov, the president of the Academy [of Sciences] under Nicholas [I] [...] also was Russian, even Archimandrite Fotij himself, who owes to Puškin his posthumous glory, would not have considered him inorodec.'

Do inorodcy reside only in Russia or can the term be used to denote minority populations in other countries? Apparently, the answer to the latter question is positive. According to (28) and (29). France and the British Empire had their inorodcy. Example (29) specifies that British inorodcy were the peoples colonized by the British Empire:

(28) Inorodec zdes' (vo Francii) ne xocet byt' inorodcem (a Francuzom). (BKSO: Katkov, M. N. [1864])

'An inorodec here (in France) does not want to be inorodec (but Frenchman).'

(29) Vozmuščalsja, slušaja, kak moi sputniki - rossijane branjat angličan za èkspluataciju inorodcev [t.e. kitajcev, indusov i t.d.]. (BKSO: Cexov, A. P. [1890])

'I was filled with indignation to hear how my Russian fellow travellers abuse the English for their exploitation of inorodcy [i.e., Chinese, East Indians, etc.]."

The difference between inorodec, inorodnnyj, on one hand, and inostranec, inostrannyj, on the other, is not always clear. The collective inorod' includes here both inorodcy and inostrancy:

(30) Ko dnju oficial'nogo otkrytija jarmarki Irbit' predstavljaet zrelišce, edinstvennoe $v$ svoem rode... Vse tut, kak kroševo $v$ čaške: $i$ moskviči, $i$ 
nižegorodcy, i kazancy, i xar'kovcy, da ešce na pridaču inorod' raznaja buxarcy, kitajcy, armjane, tatary, nemcy, francuzy, angličane [...] (BKSO: Mamin-Sibirjak, D. N. [1917])

'By the time of the official inauguration of the fair, Irbit' represents a unique spectacle... Everything here is like a medley in a cup: Muscovites, residents of Nižnij Novgorod, Kazan' and Xar'kov, in addition to all kinds of aliens [inorod']: people from Buxara, Chinese, Armenians, Tatars, Germans, Frenchmen, Englishmen.'

In the early Soviet period the term inorodec was replaced with the abbreviation nacmen '(male) member of a national minority' < nacional'noe men'šinstvo 'national minority', which soon also acquired depreciative connotations (Mokienko \& Nikitina 1998, 361). Metodika prepodavanija russkoj grammatiki $v$ skolax nacmen 'Methods of Teaching Russian Grammar in National Minority Schools' is the title of a 1929 book by the famous prerevolutionary pedagogue I. S. Mixeev, author of many times reissued textbooks of Russian for inorodcy. The title attests to the use of the abbreviation nacmen as an indeclinable noun to denote not a member of a minority group but the minorities as a group. Regarding its terminus ad quem, here is a telling quotation from chapter 4 of the first edition of the memoirs Ser'eznoe i smesnoe: Polveka $v$ teatre i na estrade 'Serious and Funny: Half a Century in the Theatre and Variety Entertainment' by Aleksej Grigor'evic Alekseev (1887-1985):

(31) Kupletisty pojavljalis' pod samymi raznoobraznymi licinami: bosjakov, barabanščikov, džentl'menov, čistil'ščikov sapog i tex, kogo my nedavno nazyvali "naciona'nymi men'šnstvami", a togda ix zvali inorodcami. (BKSO: Alekseev, A. G. [1967])

'Singers of satiric songs would appear under the most varied guises: as vagabonds, drummers. gentlemen, bootblacks as well as those whom we used until recently to call national minorities whereas at the time they were called inorodcy.'

The quotation equates the referent of inorodcy and nacional'nye men'sinstva and testifies that the latter term had been in active use "until recently". Thus we can sec the move from inorodec to nacmen after the 1917 
Revolution and the demise of the latter soon after World War II. The stages nacional'noe men'Yinstvo > nacmen'Yinstvo > nacmen (indecl.) > nacmen (declined) through which nacmen was introduced can be documented quite precisely on the basis of a collection of Communist party documents from the Smolensk Province. Nacmen'Šinstvo must have been in place by July 19, 1919, as on that day there was a meeting of the Kollegia Podotdela prosvešcenija nacmen'sinstv 'Board of the Subsection for the Education of the National Minorities' (Korsak, Levitin \& Mozgunova 1994, 19). By October 1922 nacmen'Šinsto had already been shortened to nacmen (Korsak, Levitin \& Mozgunova 1994, 47). On July 26, 1925, declined nacmeny is used in the collection of documents for the first time to denote individual members of the Jewish national minority (Korsak. Levitin \& Mozgunova 1994, 78). The last stage by which the designation for the group is transferred onto its members parallels the Canadian English colloquial use of First Nations to denote individual First Nation persons.

The survey of the most important Russian terms for Self and Other in the interconnected domains of identity demonstrates that there is only one way to be Self but many shades of otherness, among them 'not quite Self', 'nearly Other' and 'Other'. Central to the lexical constellation are the terms for Self (russkij. sovetskij cielovek, rossijanin), surrounded by a variety of terms for Other, each of which has its own angle. They are all, however, derivatives either directly of the term for Self (nerusskij 'non-Russian') or, taking Self as its zero point, from the designation for the grid of specification: with ino- or cuže- 'other' from rod 'extended family', plemja 'tribe', vera 'faith', strana 'country', zemlja 'land'. These terms feature in different historical periods in different combinations. Today some of them are more vital than others. Among the grids of specification, ethnicity and citizenship are keeping their importance up, whereas religion seems to be losing ground. 
Figure 1 provides a schematic overview of the alternative relationships among the Russian terms introduced in Table 1. It shows the two approaches to ascribing a quantitative value to the qualitative differences between Self and Other (is inorodec 'not quite Self or 'nearly Other'?). Depending on the relative importance attached to citizenship and ethnicity, one or the other model is obtained. These models compete in Russian society and this competition explains the varying scope and hierarchy of the terms involved in different discourses. There are periods for which priority of one model over the other can be postulated. For instance, the citizenship-based model was the norm among Soviet Russians.

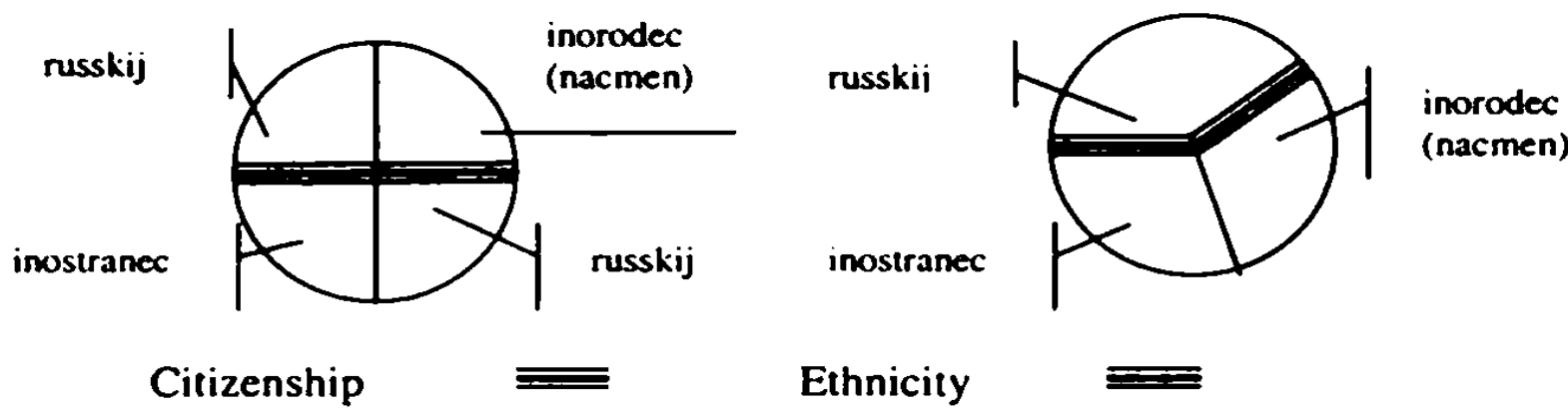

Figure 1. Russian classifications of humankind according to citizenship and ethnicity

Tuming to the object of this study, the second-language textbooks of Russian, we can see that each of the four audiences displayed in Table 1 ideally requires a targeted set of textbooks. As far as I know, the quickly expanding fourth group is only starting to receive attention, ${ }^{5}$ whereas the other three have

5 A special panel was devoted to Russian heritage speakers in the language classroom at AATSEEL 2000. Abstracts of the papers by Neil Bermel. Joan Chevalier and Nellie Belin with further bibliography are available online at clover.slavic.pitt.edw/djb/aatscel/2000. The first textbook I know of that specifically addresses this audience is RR 2002. 
had their share of specialized textbooks. The realization that each group of students has specific needs did not come overnight. Here are some early testimonies:

Russkie učebniki gramatiki napisany bol'šeju častiju Russkimi i dlja Russkix; po ètomu v nix za osnovanie obyknovenno beretsja vnutrennee značenie form, soobrazno kotoromu gruppirujutsja i opredeljajutsja samye formy. Dlja Tatar že, kotorym russkij jazyk čužd, nužno, naoborot, postavit' na pervom plane vnešnee ustrojstvo russkix form i otsjuda uže perejti $k$ ix vnutrennemu značeniju. Russkomu bylo by trudno sdelat' takoe sil'noe otvlečenie, čtoby stat' v psixologičeskoe položenie tatarina, i svoj rodnoj, vnutrenno, tak skazat' srosšijsja s russkoju prirodoju jazyk predstavit' ob"ektivno, to est' vnešne. G. Radlov ètogo neudobstva izbegnul; blagodarja lingvističeskomu svoemu obrazovaniju, on udačno ispolnil svoe delo. (Il'minskij 1873, 373)

'The Russian textbooks of grammar are written in their majority by Russians and for Russians; that is why their basis usually is the inherent meaning of the forms, which then are classified and defined according to this meaning. For the Tatars, however, to whom the Russian language is alien, one should bring to the fore the external organization of the Russian forms and from there proceed to their internal meaning. A Russian would find it difficult to disengage so much in order to assume the psychological stance of a Tatar and represent his native [Russian] language, which has, so to speak, coalesced with Russian nature in an objective manner, that is. as it is seen from the outside. Mr. [V. V.] Radlov could avoid this inconvenience and thanks to his linguistic training succeeded in his task.

Mnogoe, zatrudnitel'noe $\mathbf{v}$ orfografičeskom otnošenii dlja russkogo mal'čika, legko daetsja zdešnemu urožcncu; naoborot, pod vlijaniem pol'skago jazyka i mestnago proiznošenija russkix slov, zdešnie učeniki neredko pogrešajut protiv takix pravil, o kotoryx casto net nadobnosti i upominat' $v$ zavedenijax $s$ russkim sostavom učašixixsja. Malo togo: viijanic pol'skago jazyka sozdaet osobyj rod orfografičeskix zatrudnenij $i$ pogrešnostej, ne podxodjaščix pod naličnyja pravila grammatiki, tak čto prepodavatelju nužno byvact samomu delat' obobš̌enija i sostavljat' novyja pravila. (MD 1880,3)

-A lot of the orthographic features that are difficult for a Russian boy come easily to the local resident and, vice versa, under the influence of the Polish language and the local pronunciation of Russian words. students here break such rules that one need not even mention in an 
establishment where the students are Russian. More importantly, the influence of the Polish language causes specific orthographic difficulties and errors that have not been accounted for by the existing grammatical rules, so that sometimes the teacher has to make his own generalizations and formulate new rules.'

Moreover, the acceptance of the legitimacy of cultural differences lags behind that of linguistic ones. In the eighteenth and a great part of the nineteenth century one encounters attempts to address with the same textbook an audience of varying scale and membership. I shall illustrate this one-book-for-all approach with a couple of textbooks, although many more display features characteristic of this trend. UR 1795 aspires to teach Russian youth speak Greek and simultaneously to serve a Greek audience that wishes to learn Russian. Another example is provided by SRPJa 1838, which offers parallel texts in Russian and Polish with transcription of the Russian part according to Polish spelling and of the Polish part according to Russian spelling; in one move it promises to teach Russians to speak Polish and Poles to speak Russian.

GTJa 1835 is a comparative reference grammar of Russian, German and French, and it presents the similarities and differences of these languages. Since all three languages are treated alike, the goal appears to be to speed up the simultaneous acquisition of French, German and Russian. Theoretically, any of these languages could be the first language of students. In the preface, the author advertises the advantages of his scheme thus:

Vse sie uð̌ašcij možet obnjat' odnim vzorom, a učašcijsja, zatverdiv obščija pravila, izbegnet truda otjagotitel'nago i povtoritel'nago $v$ izučenii tex pravil, koi opisany $v$ osobennyx Grammatikax, dlja každago iz six jazykov izdannyx. (GTJa 1835, v)

'The teacher can embrace all this with a glimpse, whereas the student, having internalized the general rules, will avoid the painstaking and repetitive effor of leaming the rules described in the special grammars issued for each of these languages.' 
NERD 1822 is yet another instance. Its publisher notes in the preface the availability of a Russian-German and a Russian-French version of this textbook (NERD 1822, i). It is decmed useful to have parallel texts in different languages for the benefit of an audience that wishes to learn all of them. In spite of the title. the targeted audience appears to be cosmopolitan Russian youth.

The temptation to answer in one move everybody's needs is persistent. OPUK 1835 acknowledges that native Russians and foreigners have different needs but tries to embrace them all:

Chto kasaetsja do ego [sc. moego Grammatičeskago Opyta] otlicitel'nago xaraktera, to glavnaja certa ego ta, cto on soderžit dvojakij ili daže trojakij Grammaticeskij kurs. Ibo naperedi pomestil ja kratkij obzor zakonov vsej Ruskoj Grammatiki, otstraniv podrobnosti, isključenija, i daže nekotoryja zakony Vseobక̌cej Grammatiki, nužnye tol'ko dlja ob"jasnenija, a ne dlja zaučenija napamjat', otličl melkim sriftom. Pozadi že pod zaglavijem Dopoluenij postavil ja vse podrobnosti, nužnyja bolee dlja inostrancev, ili dlja ucitelej Ruskago jazyka, neželi dlja junyx sootezestvennikov. [...] Tret'ja knižka budet soderžat' Dopolnenija k Ėtimologii i Sintaksisu, a takže i Prosodiju, - predmety vovse nenužnye dlja učenika Ruskago i neobxodimye dlja inostrannago. Na pr. pravila o poznanii rodov Ruskimi vpolne ponimajutsja i črez priloženie $k$ imenam slov sej. sija, sie. a inostranec tol'ko togda onyja soveršenno postignet. kogda uvidit polnoe razdelenie okončanij imen po trem rodam i perečen' končašcixsja na i mužskix i żenskix. Proizvodsıvo vidov $v$ našix glagolax dlja Ruskago takže ne nużno. [...] O Prosodii i govorit' nečego; ona daže smešna dlja Ruskix, umejušcix i bez nee chitat' i govorit' ponuski. (OPUK 1835, viviii)

'Insofar as the distinctive character [of my Grammatical Attempt] is concerned, its major feature is that it contains a double and even triple course of grammar. At the beginning I provided a short overview of the laws of the entire Russian grammar, having removed all details and exceptions and even printed in a smaller font some laws of general grammar that are only necessary for explanation but need not be learned by heart. Afterwards under the title "Supplement" I placed the details necessary more for foreigners or teachers of Russian and not for our young compatriots. [...] The third book will consist of additions to the etymology [morphology] and syntax, as well as prosody - disciplines completely superfluous for the Russian student but necessary for the foreigner. For instance, the rules for determining gender can be 
understood by Russians by attaching the words sej masc., sija fem. or sie neut. 'this' to the noun, whereas a foreigner will only be able to grasp them completely when shown the endings for the three genders and the list of masculines and feminines ending in soft sign. The formation of verbal aspect is also useless to our student. [...] One need not mention prosody: it is even funny to the Russians who can speak and read Russian without it.'

As late as the end of the nineteenth century, RAPP 1898, addressing explicitly inorodcy and particularly the residents of the Caucasus, sees its effort as beneficial to inostrancy as well as native speakers of Russian:

Konstatiruja slučai, $v$ kotoryx tuzemcy Kavkaza grešat protiv pravil'nosti russkago proiznošenija, Azbuka èta tem samym možet pobuždat' ix vnimatel'nee prislušivat'sja $k$ ustnoj reči korennyx russkix i, takim putem, ispravit' svoi oxibki. Inostrancy po nej mogut usvoit' pravila proiznošenija, propustiv, konežno, vse to, čto special'no kasaetsja tuzemcev Kavkaza. Prisutstvie $v$ Azbuke zamexanij otnositel'no nepravil'nago proiznoł̌enija tuzemcev, ešče lučše vyjasnit im èti pravila. Nakonec, russkie učeniki, znaja pravila, po koim proiznoక̌enie izustnoj reči otličatsja ot pisannoj, legče mogut usvoit' pravopisanie, kotoroe udaetsja im s takim trudom. (RAPP 1898, First preface)

'Stating the incidences of mispronunciation by the residents of the Caucasus. this Alphabet will induce them to listen more carefully to the speech of native Russians and thus correct their mistakes. Foreigners can use it to Icam the rules of pronunciation, omitting of course everything that concerns the residents of the Caucasus specifically. The remarks on mispronunciation by the locals will clarify the rules for them even better. And finally, if Russian students learn the rules that distinguish between oral and written speech, they will find it easier to master the spelling that presents them with so many difficulties.'

Nowadays second-language textbooks and school grammars are based on the theoretically oriented reference grammars prepared for and by native speakers. In the early period the distinction between these three categories of books is not as clear-cut. Moreover, the first Russian grammar ever was written in Latin and German by H. W. Ludolf for the benefit of a forelgn audience (GR 
1696). This grammar, together with some later publications, was the outcome of a religiously motivated interest in promoting the study of Russian, an interest which was rooted in the aspiration of the seventeenth-century Pietist movement to build bridges with other Christian denominations (Cyževśkyj 1939, 17-18). ${ }^{6}$

Other early reference grammars were also written by foreigners and addressing second-language leamers (e.g., GRS 1704; GMRF 1724; RG 1750; MLR 1811). ${ }^{7}$ The Russian situation is no different from the situation elsewhere. Interest in the grammar of their own language among the native speakers of German. French or English also lags behind that of foreigners (Unbegaun 1969, v). Besides, the approach to teaching different audiences is frequently the same. Regardless of target, the collections of reading materials are based on readings written for native speakers with other goals in mind. My earliest collection of readings that specifically addresses a foreign audience is RX 1848. Its author, St. Baranovskij, gives in the preface the following reasons for his decision: (1) since language learning precedes literature learning, it is better that students first be exposed to few but exemplary texts; (2) stress needs to be marked on Russian words: (3) the texts should present to students Russian life and important historical personalities. The specific needs of the audience are also addressed by offering Russian glosses to some difficult and rare expressions (RX 1848, i-xi).

Specialized textbooks were devoted in Imperial Russia to various groups of inorodcy: Germans (PRGN 1853: KČU 1878-9), Latvians (RRJa 1877; KC 1888), Jews (NSRJa 1875), Poles (NORJa 1839; PZRJa 1868: SRJa 1870; MD 1880). Tatars (GRJa 1873), Bashkirs (PPU 1899), Georgians (RS 1899), Armenians (RPURU 1869), Romanians (RRG 1827) and so on. Neither the list of ethnic groups nor that of textbooks is exhaustive. These efforts were the outcome of a new attitude towards the non-Russian subjects of the Russian empire as fullfledged citizens with their own history, culture and way of life, an attitude

- Regarding the role of German Pietusts for pupularizing Russian among Western audiences. sce also Benz 1954 with further biblingraphy. 
budding in the second half of the nineteenth century. It was characteristic, for instance, of the nineteenth-century Russian pedagogue and missionary in the Volga region N. I. Il'minskij, who created a whole educational system and formed a network of schools (Gračev 1995; see for instance SRJaK 1861).

In the Soviet period textbooks were produced for dozens of ethnic groups, sometimes with a differentiation by age or profession (e.g., URJa 1927 for the Red army, URJa 1938 for young Cukča schoolchildren or URJa 1945 for adult Latvians). A special analytical unit (The Division of Russian as a Language of Inter-Ethnic Communication) was organized in the Institute of the Russian Language of the Soviet Academy of Sciences in order to promote both the production of textbooks of Russian for non-Russian citizens of the USSR and theoretical reflection on this activity. All such textbooks were culturally and ideologically in line with the dominant official views of the time and will be considered here only partially. No specific cultural information about Russians was offered in them in consonance with one of the most important Soviet tenets ("internationalism"), but that is also true of the early Soviet textbooks that target foreign audiences.

It is clear by now that my own interest focuses on textbooks addressing nerusskie 'non-Russians' (i.e., inostrancy and inorodcy (nacmeny]), the only ones that can be labeled Russian second-language textbooks proper.

Viewed in the framework of verbal communication as developed by Roman Jakobson (1985), second-language textbooks represent a message that refers to a context (the Russian language. society and culture) and is conveyed by an addresser (the author of the textbook) to an addressee (the intended audience) in a code (the Russian language used as object language and metalanguage as well as any other languages that may have been employed as metalanguage). The cultural identity of both author and audience has an impact on the characteristics

The earliest reference grammars by native speakers in my collection that target foreign 
of the message and its relationship to its context. For instance, the significance of textbook authors of the fourth category (Russians abroad) was especially great during the Soviet period, but it is authors of the first and third categories (native Russians and foreigners, respectively) who have always dominated the field. Nowadays we are starting to hear the voices of the previously silent second group (e.g., REW 2000). We already saw that audiences can be divided into the same four categories, three of which are of potential interest in terms of secondlanguage textbooks.

Textbook authors are necessarily holders of the alternative models of humanity represented in Figure 1. In conformity with their choice, they may display preferences for one over the other approach to presenting the Russian Self to their audience. The expectation is that holders of the citizenship-based model of humanity would tend to treat audience groups two and three differently and, perhaps, cluster the latter with group four, whereas holders of the ethnicity-based model would prefer to treat them alike but exclude group four from the mix. Unfortunately, there is little evidence that this expectation is fulfilled because authors tend to specialize and target in their work the same audience over and over again, no matter how it is defined. I shall give two examples of the kind of conclusions that one can draw on the basis of my collection of second-language textbooks. The author of many textbooks for inorodcy I. S. Mixeev, whom I have already mentioned. published in 1913 in Kazan' and in 1915 in Tokyo a textbook with the same title (PKORJa 1913 and PKORJa 1915). The conclusion that suggests itself is that the author was able to convince his Japanese publisher that what was a good textbook for inorodcy should satisfy a Japanese audience as well.

The German audience of Russian second-language textbooks defies classification in terms of the opposition between inorodcy and inostrancy. The number of Germans inside the Russian empire started growing during the

audiences specifically are MG 1706. AG 1731 and NRG 1788. 
reventeenth century, as many settled in Russia and others, especially those in the Baltic states, were incorporated together with the territory they inhabited. More than thirty textbooks in my collection address German speakers. ${ }^{8}$ The most Inportant clue as to whether the intended audience was situated inside or outside the empire is the place of publication: one can assume that both textbooks published in Reval, Mitau and Riga, on one hand, and those published in Leipzig, Vienna and Berlin, on the other, were for local consumption, which presumes a German-inorodcy audience in the former case and a German-inostrancy audience In the latter. The identity of the authors appears to have played no role: authors with German names such as Johann Philipp Wegelin. August Wilhelm Tappe, Karl Šliter and I. Pihlemann could publish textbooks in Russia, and Russian suthors were welcome to publish textbooks in the German-speaking countries 'for instance, Nicolai Bubnoff, Fedor Golotuzov and Alexis Markow). But it ums out that the same textbooks could have editions issued by publishers inside and outside Russia (cf. RSL 1773 and RSL 1789; RX 1880 and RX 1889). This is 2n indication that German speakers inside and outside the Russian empire were reated as one group: that is, in accordance with the ethnicity-based model in Figure 1. It is more difficult to pinpoint, however, whose classification this is - of the Germans or of the Russians involved in Russian second-language teaching is it is not clear whose decision it was (the author's or the publisher's) to define sudiences in this way.

We shall see later which characteristics of the textbooks themselves may relp us distinguish between inorodcy (nacmeny) and inostrancy as the intended sudience of Russian second-language textbooks. If we count the first language of 1 person as a marker of ethnicity rather than citizenship, the necessary focus of extbooks on language seems to push their authors towards the ethnicity-based nodel of humanity. Apparently, this is what happened in the case of the Russian second-language textbooks for Germans. Language and ethnicity, however, need

\footnotetext{
'For a historical survey of the study of Russian in the German-speaking lands see Basler 1987.
} 
not go hand in hand, as the situation in multicultural states proves over and over again. Realization of this possibility is encapsulated in some notorious usages of the Russian adjective russkojazycinyj lit. 'Russian-language' employed as the attribute of a head noun denoting a person: for instance, russkojazyčnyj pisatel' 'an author writing in Russian'. The adjective was attested for the first time in writing in the mid-1980s (Levašov 1997, 719). In the post-Soviet world characterized by increased salience of ethnic identities, 'Russian-language persons' may be seen with suspicion by Russians and non-Russians alike: by the former because russkojazyčnye are deemed to have acquired only the language component of all the aspects of a Russian identity and by the latter because, regardless of their more intimate characteristics, they are the embodiment of the Other. In the former, narrower meaning, russkojazyčnye are those inorodcy. nacmeny or nerusskie who have successfully learned Russian, the graduates of the schooling process that in our time and age requires second-language textbooks. In the latter, broader meaning, Russians and Russian-speaking nonRussians are lumped together and opposed to a non-Russian Self.

The divisions of humanity by the two grids of specification - ethnicity and citizenship - are also relevant for the Russian second-language textbooks as a message. The speaking subject of Russian is necessarily a character of honour in Russian second-language textbooks. Traditionally, speakers of the second group (be it they Dagestan mountaineers [RX 1872, 458-462; DKNJR 1938, 179-181]; Armenians [RMLR 1947, 327-329]; Tatars, Estonians and Armenians [RJaV 1976. 206]; Georgians and Abkhaz [RREG 1992, 69-73, 156-160]; Belorussians [DKN]R 1938, 89-91]; or Gipsies [DGR 2000, 149-152]) have accompanied speakers of the first group, and this can be considered one of the great cultural constants in Russian textbooks. Speakers of the third group are represented more frequently in textbooks written by foreign authors, but their presence increases in textbooks by Russian authors as time goes by. Only recently the permanent residence of Russians abroad has gained legitimacy among insiders, and this 
opened the door for characters of the fourth group, like Anton, who is nemnogo russkij 'a little Russian' because his grandmother was Russian and used to own a large house and land near Moscow (RJaV 1995, 21); the Russian parents of a friend of John's sister (RB 1999, 191); or the following cosmopolitan Russian woman:

(32) - Vy tože predstavitel' firmy?

- Net-net. Ja Castnoe lico.

- Vy russkaja?

- Da.

- A-a, ponimaju. Iz Londona - domoj?

- Ne sovsem. Iz Londona v Moskvu domoj, potom iz Moskvy v London tože domoj.

- Izvinite...?

- V Moskve živet moja mama, a v Londone - muž. Ja živu i v Moskve, i $\checkmark$ Londone.

"Are you also the firm's representative?"

"Oh, no. I'm a private visitor."

"Are you Russian?"

"Yes."

"Oh, I see. You must have come home from London?"

"Not quite. Home from London and then home to London."

"I don't quite follow you..."

"My mother lives in Moscow, but my husband lives in London. So I live in both Moscow and London." (KK 2000, 65; English translation as in the original) 


\section{Typology of Second-Language Textbooks}

Aside from their direct and declared goal of teaching people how to speak and understand a foreign language, second-language textbooks provide at the very least an image of the target language speaking subject, which may evolve into an account of native speakers' society as seen by the author. Secondlanguage textbooks are therefore one of the checkpoints through which national and ethnic social boundaries can be crossed by outsiders willing to gain access to the inner space of a nation or an ethnic group. Their authors play the role of mediators or cultural brokers between readers and the society where the studied language is being spoken. Their choice of strategy makes them either bonafide guides or gatekeepers.

Should intent be part of the definitions of bonafide guides and gatekeepers? The answer to this question is positive. As cultural differences came only gradually to the attention of textbook authors. the distinction between bonafide guides and gatekeepers should apply only to the period of time since the legitimacy of cultural differences has been accepted as a norm.

Depending on the author's identity, one can distinguish between accounts that are based on an insider's or an outsider's view on society. Within each category there is a range of possible stances as far as cross-cultural comparison is concerned. Obviously, the presence or absence of cross-cultural companson is relative. When cross-cultural comparison is present, outsider and insider bonafide perspectives differ in vantage point. If authors target a particular foreign audience, insider authors may provide that audience with an account of elements of their own society side by side with that of the society in question. This is not frequently the case because insider authors based in Russia target as a rule the ethnically and nationally undifferentiated average inostranec or inorodec, as one 
can see in GTJa 1835, PKRJa 1847, RX 1848, RS I 1896, RS II 1898, RS III 1898, RM 1901, DD 1902, RU 1909, RR I 1914, URJa 1973, RJaIS 1974, RJaV 1976, UGR 1977, TNM 1994, DDE 1994, DDP 1995, PFK 1995, RJaV 1995, P 2 1996, CRR 1997, MPMR 1998 and NIR 2000. Such a choice of target also has a considerable impact on the presentation of the grammatical material, as we are all aware.

The outsider perspective will have cross-cultural comparison embedded in its vantage point, as demonstrated for instance in REB 1938, DKNJR 1938, RSC 1940, AR 1992, LTL 1996, N 1996-1997, G 1998-1999, R 2000 and RT 2000. Gatekeeper authors with an outsider or insider perspective will use a variety of devices to keep cross-cultural encounter to a minimum. A necessary prerequisite for the success of both types of gatekeeping enterprise is the ignorance of their audiences as far as the society in question is concerned. In both cases whole spheres of social life will intentionally be glossed over.

An ethnocentrically oriented outsider will produce a garbled gatekeeper account. Practically, this is achieved by a systematic substitution of the social realities of their own society for those of the respective society or their manipulation allegedly in the interest of their readers. CRAM 1961 is an explicit example of this approach dealing with "familiar aspects of American college life - classes, campus activities, entertainment, etc. - rather than their Russian analogues" (Neiswender 1962, 15-16). As Neiswender goes on to say "the usefulness of this approach in acquiring a mastery of current Soviet usage may be questioned but the book will probably appeal to a college audience." This stance was common for the large Soviet second-language textbook industry addressed to Soviet audiences headed by publishing houses like Russkij jazyk. Vysšaja škola. Progress, and so on. As an example, one can point at E 1938. In a Soviet textbook of Modern Greek, which I used in the early 1980s, the action was taking place in the Soviet Union and all the characters were Soviet students who lived in student dormitories; danced in the evening at the léskhē 'club, clubhouse. casino'. 
which was a full equivalent of a Soviet klub or dom kul'tury; and called each other sýntrophos m. / syntróphissa f. 'comrade', something Greeks never do.

It is, however, important to emphasize that the boundary between bonafide guides and gatekeepers is not clear-cut. It depends on intent rather than the precision of the projected image as outsider bonafide guide authors need not be fully aware of the cultural differences between the society they describe and their own because knowledge of a foreign language does not automatically imply cultural knowledge. One of the first Russian words that I leamed as a junior highschool student was brynza 'feta cheese', a staple food in Bulgaria. As the Bulgarian authors of my fifth-grade textbook must have been guided in their selection of vocabulary for a beginners' course by considerations of frequency, this curious choice probably reflects their conviction that feta was important to everybody alike - and Russians could not be any different from Bulgarians in this regard - and therefore Russian brynza should be as much part of Russian core vocabulary as Bulgarian sirene undoubtedly is."

In a similar vein, RSC 1940, 84-85 introduces for active use the following kinship terms: mu: 'husband'. ̇ena 'wife', defi 'children', syn 'son', doč' 'daughter', otec 'father', mat' 'mother', rodireli 'parents', babuška 'grandmother', deduška 'grandfather', vmučata 'grandchildren', sestra 'sister'. brat 'brother'. svodnyj brat 'stepbrother'. macexa 'stepmother', pasynok 'stepson', padčerica 'stepdaughter'. svojak 'brother-in-law [husband of wife's sister]', żenix 'fiancé', nevesta 'fiancée', sużenyj 'fiancé (in folklore)', svekor 'father-in-law [husband's father]', svekror' 'mother-in-law [husband's mother]', test "father-in-law [wife's father]'. tešca 'mother-in-law [wife's mother]'. zjar' 'son-in-law'. nevestka 'daughter-in-law: sister-in-law'. snoxa 'daughter-in-law in relation to her father-in-law'. surin 'brother-in-law [wife's brother]', svojačenica 'sister-in-law [wife's sister]'. dever' 'brother-in-law [husband's brother]', zolovka 'sister-in-law [husband's sister]", dvojurodnyj brat '[male] cousin once 
removed', dvojurodnaja sestra '[female] cousin once removed', plemjannik 'nephew', plemjannica 'niece' (RSC 1940, 84-85). This thirty-six item list is at least twice the length of the standard one. Besides, some of these terms are only vaguely familiar to urban Russians. ${ }^{10}$ Obviously, the author was prompted to include so many kinship terms at this early stage of learning the Russian language by usage in his native Serbian.

Insider gatekeepers too produce garbled accounts intentionally. In this case it is not ethnocentrism that causes the distortion: there isn't anything in insiders' ethnocentrism that could prevent them from being bonafide guides, of course within their own perspective of society. I would suggest that the main reason for the production of garbled insider accounts is the desire to keep the national or ethnic social boundary impermeable, not to let outsiders come too close to insiders because the existence of a well-protected border is seen as a necessary precondition for the existence of the group. In the case of the Soviet Union this stance was tacit, hidden behind the customary talk about internationalism, solidarity of the world proletariat and friendship among nations. The mechanism through which insider gatekeepers achieve their goals will be dealt with in chapter 7.

On the other hand, insider authors of both sub-varieties may have misconceptions about the cultural characteristics of the audience they address. This becomes particularly clear when they introduce in their textbook a character that represents that audience. A good example is the American Steve Ford in NIR 2000, whose views and behaviour are hardly typical.

\footnotetext{
'In fact, Russians eat feta only if they are left no other choice. Feta was the last kind of cheese to disappear from the shelves of Moscow stores in the early 1990s.

${ }^{10}$ Surin 'wife's brother' is a relative that only married men can have. The precise meaning of the kinship term is. however, blurry for speakers of Russian. In his famous song Dialog u televizora 'Dialogue by the TV set', the Russian bard Vladimir Vysockij makes his female character Zina. who is watching clowns on TV. say to her husband Vanja: a tot poxoz. net pravda lan: na surina, takaja $₹ p$ 'jan' 'and that one looks like the surin, doesn't he. Vanja, the same wino". Obviously. Vysockij did not know who surin was. Moreover, I have had the chance to listen to the song repeatedly with native speakers of Russian. None ever commented on the incongruity. If
} 
Authors of the bonafide guide type describe the speakers' society as they see it, whereas authors of the gatekeeper type construct a distorted image that corresponds to their interests. In other words, only authors of the former type strive towards cross-cultural communication. Despite this significant difference, all textbooks continue to be acts of communication, albeit functionally diverse. Specifying the communicative strategies of insider bonefide authors, we can distinguish between two varieties: the Proselytizing and the Common-Ground Model. The former textbook model makes no noticeable distinction between inorodcy and inostrancy audiences for the purposes of indoctrination, whereas the latter makes such a distinction, providing a separate account of Russian society na eksport 'for external use'. The idea that there should be a double standard of performance (one for internal and another for external use) is inherent to many aspects of social life, starting with hospitality. The double-standard gulf demarcates inner space (no matter how it is defined for current purposes) and opposes it to outer spaces.

The textbooks subscribing to the Proselytizing Model try to convince and convert their readers. The directness with which authors set out to perform their task is shown in (33). Talking about the opinions of Westerners about Russia and Russians, A. S. Xomjakov evaluates them in no uncertain terms:

(33) I skol'ko vo vsem ètom vzdora, skol'ko nevežestva! Kakaja putanica v ponjatijax i daže v slovax, kakaja besstydnaja lož', kakaja naglaja zloba! (RX $1872,64)$

'And how much nonsense there is in all this, how much ignorance! What a mess of notions and even words, what a shameless lie, what brazen spite!'

Proselytizing textbooks typically take a prescriptive stance and hand down value judgements. Among the expected discursive markers of this model are modality (as in [34], [35] and [36]) and the high frequency of axiological vocabulary such as xorošo 'well' (37); prijatno 'pleasant', kul'turno 'in a

I made the point. my Russian friends would only shrug their shoulders noncommittally and dismiss the issue as insignificant. 
civilized manner' (38); velikij 'great', lučšij 'best' (39); and vyšsee dobro 'the supreme good' (40).

(34) Tovarišči, na zaščitu SSSR! Comrades, for the defence of the U.S.S.R.! (RESW 1933, 19; English translation as in the original)

(35) Texniku $v$ massy! Technique to the masses! (RESW 1933, 21; English translation as in the original)

(36) $V$ boj za pobedu socializma vo vsem mire! (RESW 1933,90 )

'Let us fight for the victory of socialism in the whole world!'

(37) Teper' my vse živem xorošo. Naša partija i pravitel'stvo delajut vse, ctoby vse trudjašciesja žili xorošo. (MPLR 1952, 100)

'We all live well now. Our party and government are doing everything to ensure that the toiling people live well.'

(38) Kak prijatno i kul'turno možno provesti zdes' svobodnyj den'! Partija i pravitel'stvo zabotjatsja ob otdyxe trudjaščixsja. (MPLR 1952,124)

'In what a pleasant and civilized manner can one spend one's day off here! The pany and the govemment are taking care of the toiling people's entertainment.

(39) Vot požemu rumynskij narod bezgraniěno blagodaren sovetskomu narodu i velikomu voždju vsex trudjaščixsja, lučšemu drugu našego naroda, znamenoscu mira - tovarišcu Stalinu. (MPLR 1952, 174)

'This is why the Romanian nation is infinitely grateful to the Soviet nation and to the great leader of all toiling people, the best friend of our nation, the standard-bearer of peace, comrade Stalin.'

(40) Služit' vragam - vysšee dobro. Platja dobrom za zlo, čelovek podražaet Bogu. (RS III 1898, 83)

'Serving one's enemies is the supreme good. By repaying evil with good, one imitates God.'

The possibility to choose between the Proselytizing and the CommonGround Model in addressing foreign audiences highlights the perceived heterogeneity of this foreign audience, or as the Russian proverb has it. Kurica ne 
ptica. Bolgarija ne zagranica 'A hen is not a bird and Bulgaria is no foreign country'. We already saw in chapter 1 that the distinction between Self and Other is gradual and fluid. My collection of Russian second-language textbooks contains few textbooks of the Proselytizing Model and most of these (with the exception of URJa 1973 and RREG 1992) address an audience that is perceived to be closer to Self than the "real" Other. Thus, Proselytizing Imperial textbooks RX 1848, RX 1872, KC 1888, RS III 1898 and RM 1904 target inorodcy, whereas Proselytizing Soviet textbooks may also target the proletariat worldwide (RESW 1933, LRSDA 1933 and RT 1935) or the population of the East European buffer zone (MPLR 1952 and RJa 1952). I specifically included textbooks addressing Romanian and Bulgarian audiences to check whether their different traditional attitudes towards Russia (negative in Romania and positive in Bulgaria) played a role in the realization of the Proselytizing Model, but I could detect no sensitivity to such matters, as one can see from these typical reading selections:

(41) Ėto naš zavod. My rabotaem zdes'. Teper' utro. My idem na zavod. Vot tovarišč Popesku; on tokar'-staxanovec. On primenjaet sovetskie metody raboty. Ėto tovariš̌ Nikolau, on mexanik-udarnik. Vot naš direktor i naš inžener. Vot i naš zavod. Ėto dvor. Zdes' ugol', tam železo i čugun. Ėto bol'šoe okno - naš cex. Ėto dizel'-motor, a èto dinamo-mašina. Éto sovetskie mašiny. My idem v cex. Vot prizyvy: Da zdravstvuet rumyno-sovetskaja družba! Da zdravstvuet velikij Stalin! Da zdravstvuet tovarišč George Georgiu-Dež! Vot naša stengazeta. Vot plan i grafik.

- Gde ivoj stanok?

- Moj stanok zdes', nalevo.

Teper' sem' casov. My slyšim gudok. My rabotaem vosem' casov. Naš zavod perevypolnjaet plan. (MPLR 1952, 46-47)

'This is our plant. We work here. It is morning now. We are going to the plant. Here is comrade Popescu. He is a lathe operator working according to the method introduced by Staxanov. He applies Soviet methods of work. This is comrade Nicolau. He is a mechanical engineer, a participant in the shockworker movement. Here are our director and our engineer. Here is our plant. This is the courtyard. Here is the coal, over there the iron and the cast iron. This big window is our shop's window. This is the diesel engine and that the dynamo. Thesc are Soviet machines. We arc going to the shop. Here are the 
slogans: Long live the Romanian-Soviet friendship! Long live the great Stalin! Long live comrade Gheorghe Gheorghiu-Dej! Here is our wall newspaper. Here are the plan and the timetable.

"Where is your lathe?"

"It is here, to the left."

It is seven o'clock now. We hear the whistle. We work eight hours a day. Our plant exceeds the plan.'

(42) Do Oktjabr'skoj revoljucii $v$ Rossii na uzkix poloskax ženščny žali serpami, sognuvšis’ do zemli. Rabota šla tjaželo i medlenno. Zerno osypalos' i propadalo naprasno. Posle žatvy nado bylo svjazyvat' snopy, perevozit' ix, obmolacivat', proveivat'. Posle revoljucii v Sovetskom sojuze pojavilis' kolxozy $i$ sovxozy. Tam rabotajut mašinami. Osobenno složnaja $i$ ineteresnaja mašina kombajn. Kombajn i žnet, i molotit, i provevaet zemo. Gotovoe, Cistoe zerno ssypaetsja $v$ osobyj bak naverxu mašiny. K kombajnu pod"ezžaet avtomobil' ili traktor s teležkami i razgnužaet kombajn. O takoj mašine ran'క̌e krest'janin ne mog i mečtat'. Posle devjatogo sentjabrja 1944 goda kombajny pojavilis' i v Bolgarii - $v$ trudovyx kooperativnyx zemledel'českix xozjajstvax. Prislal ix sjuda Sovetskij Sojuz. (RJa 1952, 50-51)

'Before the October Revolution women in Russia used to reap with sickles, stooping to the ground on narrow lots. Work was proceeding slowly and with difficulty. The grain was falling off and was wasted. After reaping, one had to bind sheaves, cart, thresh and winnow. After the revolution collective and state farms appeared in the Soviet Union. People there work with machines. An especially complex and interesting machine is the combine. The combine harvests and threshes and winnows the grain. The finished clean grain is stored in a special tank on top of the machine. A car or a tractor with trailers approaches the combine and unloads it. A peasant could not even dream of such a machine before. After September 9, 1944 combines appeared in Bulgaria as well - on the cooperative farms. They were sent here by the Soviet Union.'

The Soviet experience is forcefully and repeatedly depicted in these two Proselytizing textbooks as the only valid way of life (another eloquent quote is [230]). The expected reaction to the benefactions of the Soviet Union is East Europe's eternal gratitude, as stated over and over again in the textbooks.

The Common-Ground Model follows a universal trend in interethnic communication that "implies a recognition of limitations on shared understandings, differences in criteria for judgment of value and performance, 
and restriction of interaction to sectors of assumed common understanding and mutual interest" (Barth 1969, 15). In the Common-Ground Model one can distinguish between two subtypes, depending on the size of the common ground. The narrow definition takes what is universally human as the common denominator between Self and the Others, who form the intended audience of the textbook. The broad definition of common ground assumes that cultural distinctiveness is the norm and presents Self to Others, each of which contributes in their unique ways to the spectrum of human diversity. Thus the textbooks written by insider bonafide guides form a continuum with textbooks that place Self over Other and aim at indoctrination at one extreme; the Broad CommonGround Model that attributes equal weight to the cultural specifics of Self and Other in the middle range; and the Narrow Common-Ground Model, which brackets cultural peculiarities, out at the other extreme.

For reasons that will become clear later, the three remaining models - the Holy-Rus, the Civilized-World and the Global-Village Mosaic Models - can be discussed in detail only in chapter 5 . Chapter 2 must be limited to an exploration of the modem second-language textbooks. Table 2 summarizes the typology of second-language textbooks according to awareness of the legitimacy of cultural diversity, vantage point, desire to provide authentic cultural information, availability of cross-cultural comparison, imagined relationship between Self and Other and communicative strategies. For the sake of completeness, I add to the five modem second-language textbook models the three non-modem types, which I will outline later. As my narrative unfolds in the following chaptcrs, the types of Russian second-language textbooks introduced here will be redefined in discursive terms. 


\begin{tabular}{|c|c|c|c|c|}
\hline \multirow{2}{*}{\multicolumn{4}{|c|}{ I. Premodern second-language textbooks }} & $\begin{array}{l}\text { <Holy-Rus Model> } \\
\text { (Self same as Other inside } \\
\text { framework A) }\end{array}$ \\
\hline & & & & $\begin{array}{l}\text { Civilized-World Model } \\
\text { (Self same as Other inside } \\
\text { framework B) }\end{array}$ \\
\hline \multirow{6}{*}{$\begin{array}{l}\text { II. } \\
\text { Modern } \\
\text { second- } \\
\text { language } \\
\text { textbooks }\end{array}$} & \multirow{2}{*}{\multicolumn{3}{|c|}{ Gatekeepers }} & $\begin{array}{l}\text { Ethnocentric Outsider } \\
\text { Model } \\
\text { (Outsider Self ousts insider } \\
\text { Other) }\end{array}$ \\
\hline & & & & $\begin{array}{l}\text { Cooped-Up Insider Model } \\
\text { (Insider Self hides from } \\
\text { outsider Other) }\end{array}$ \\
\hline & \multirow[t]{4}{*}{$\begin{array}{l}\text { Bonafide } \\
\text { guides }\end{array}$} & \multirow[t]{3}{*}{$\begin{array}{l}\text { Insider } \\
\text { perspective }\end{array}$} & $\begin{array}{l}\text { Predominance } \\
\text { of Self }\end{array}$ & $\begin{array}{l}\text { Proselytizing Model } \\
\text { (Insider Self prevails over } \\
\text { outsider Other) }\end{array}$ \\
\hline & & & $\begin{array}{l}\text { Equality of } \\
\text { Self and } \\
\text { Other }\end{array}$ & $\begin{array}{l}\text { Broad Common-Ground } \\
\text { Model } \\
\text { (Insider Self shares cultural } \\
\text { treasures with outsider } \\
\text { Other) }\end{array}$ \\
\hline & & & & $\begin{array}{l}\text { Narrow Common-Ground } \\
\text { Model } \\
\text { (Insider Self affirms its } \\
\text { humanity to outsider Other) }\end{array}$ \\
\hline & & \multicolumn{2}{|c|}{ Outsider perspective } & $\begin{array}{l}\text { Cross-Cultural Comparative } \\
\text { Model } \\
\text { (Outsider Self weighs } \\
\text { insider Other) }\end{array}$ \\
\hline \multicolumn{4}{|c|}{ III. Postmodem second-language textbooks } & $\begin{array}{l}\text { Global-Village Mosaic } \\
\text { Model } \\
\text { (Self as varied as Other) }\end{array}$ \\
\hline
\end{tabular}

Table 2. Models of Russian Second-Language Textbooks 


\section{Second-Language Textbooks as a Discursive}

\section{Formation}

Russian second-language textbooks are so many nodes that form a network "caught up in a system of references to other books, other texts, other sentences" (Foucault 1972a, 23). In this chapter, I would like to look more closely at the network itself and its nodes.

My study is based on about one hundred and fifty textbooks from the Imperial, Soviet and post-Soviet periods of Russian history written mostly but not exclusively by insiders. Those that have been cited in the study are included in the list of sources. Most textbooks were found by searching the catalogues of the two largest academic libraries in Russia (the Russian State Library in Moscow and the National Library of Russia in St. Petersburg) and the electronic database WorldCat, as well as published bibliographies (such as Vinogrador 1957, Neiswender 1962, IhI-Behrend \& Tretjakow $\mid 981$ and Ihl-Behrend \& Schwalbe 1982). Contrary to expectations, the frequency with which Russian secondlanguage textbooks have been published is not constant. Slack periods altemate with periods of proliferation: slack period until the 1870s; prolific period 1870s1917; slack period 1917-1945; prolific period 1945-present time." The second slack period came as a surprise to me, especially since the pace in the production of Russian second-language textbooks was increasing very slowly up until the 1960s.

The textbooks cover the time span from the middle of the sixteenth century to 2000, which means that the earliest textbooks belong in fact to the Muscovite period. The first is Thomas Schroue's ERB 1546 (Syrku 1897, 1063 -

\footnotetext{
"Franz Basler cites H. Baumann's statıstics of Russian texthx)ks for Germans (Basler 1987. 42 46. 100), which follows a similar curb attributed by him to shifts in the political climate.
} 
1067; Alekseev 1951; Bolek, Chodurska, Fałowski \& Kunińska 1997). ${ }^{12}$ The manuscript was copied after an earlier source in the year before Ivan the Terrible was crowned as tsar in 1547. It contains Russian dialogues on business topics and thematic vocabulary lists with a German parallel translation. Another undated manuscript from the middle of the sixteenth century, ERB s.a., written probably in Pskov (Falowski 1996, 161-167), starts with the words Ein Rusch Boeck in Low German and includes short Russian texts with German translation (on topics such as Christ's crucifixion. Noah in the deluge and business relations) and thematic vocabulary lists (Syrku 1897, 1059-1063). The third is Tönnies Fenne's LGMSR 1607 written in Pskov during the so-called "Time of Troubles", although the tumult of the period was not reflected in the textbook (Gernentz, Korol \& Rösler 1988, 29-31). It contains a thematic vocabulary, a grammatical description of Russian, domestic, social and commercial conversations, samples of diplomatic correspondence, proverbs, riddles, sayings, religious texts and finally samples of all Russian letters and their names. Next comes Heinrich Newenburgk's DRS 1629, a manuscript containing thematic vocabulary lists, a Russian alphabet, a dialogue "between two good friends" and seventeen psalms in Russian. It is contemporary with the rule of the first Romanov, Mixail Fedorovic (1613-1645). The next manuscript, the anonymous RHG 1635-1648, contains three dialogues in Russian and was translated from an original going back to the Colloquia et dictionariolum septem linguarum by Noël de Berlaimont (Keipert 1993). It has been dated between 1635 and 1648, which coincides with the last part of the rule of Mixail Fedorovic and the beginning of his son Aleksej's rule (1645-1676). Judging by the paleographical and linguistic evidence, the sixth item. TW 1680s, was produced by one or two professional scribes in the Russian Northwest or the Swedish Baltic possessions (the Novgorod-Narva region) before or during the first years of Peter's rule (16821725). It contains thematic vocabulary lists, sample conversations on everyday

12 The author Thomas Schroue presumably lived in Dorpat (Tartu) in Estonia in the fifteenth 
and business matters, an excerpt from the New Testament and grammatical material. Only the seventh textbook on my list, the famous Russian grammar by Heinrich Wilhelm Ludolf, GR 1696, can be attributed to the Imperial period by right.

Russian second-language textbooks appeared in response to the needs of West European merchants, especially those of the Hanseatic League, conducting business in Russia (Basler 1987, 9-11), as well as Baltic officials dealing with Russian merchants (Johansen 1955). The five earliest manuscripts mentioned above, as well as later textbooks (such as VRG 1707), were shaped by the West European experience, dating back to antiquity, of leaming foreign languages. There are reasons to believe that few of the manuscripts that circulated at that time were actually preserved (TW 1680s, 219-220). Being an integral part of this intellectual tradition. the first Russian second-language textbooks owe much in terms of both form and content to the study of Latin in the German, French and Dutch cultural space and to the study of Italian in the context of Italian-German business relations since the $15^{\text {th }}$ century (Gementz, Korol \& Rösler 1988, 13-35).

Even a cursory look at the earliest items on my list of sources proves that the question of what should count as a Russian second-language textbook for the purposes of this study is not an idle one. Finding the correct answer in the gray area between a broad and narrow definition of my objcct of study is a matter of balance. The broad definition is functional. It includes any book compiled for the purposeful acquisition of Russian as a second language. The narrow definition based, on the intuition of the average sccond-language learner, is structural. It would rate as second-language textbooks only books organized in a specific way. Their minimum content is limited to texts of growing difficulty in the target language, explanation of its grammatical structure and exercises. They are also frequently illustrated and have a glossary and sometimes a key to the exerciscs. The prototypical representatives of Russian second-language textbooks are those

century (Alekseev 1951). For counterarguments see Gernentz. Korol \& Rösler 1988, 20-27. 
narrowly defined. These textbooks, the proper ones, share functions with a variety of teaching materials such as bilingual dictionaries, reference grammars of the target language, (adapted) reading selections and handbooks that elaborate on specific areas of the target language (verbs of movement, intonation, phraseology, etc.). The earlier a textbook was compiled, the greater the chances that its author's idea of a second-language textbook differs from our own. I have strived as much as possible to limit myself to second-language textbooks proper, but that was not always possible or wise. In the interest of a more comprehensive coverage, teaching materials adjacent to second-language textbooks proper were also consulted and sporadically included as sources.

Terminological clarity, precision and stability are taken to be a sign that a certain concept has crystallized. The most frequent Russian term for the narrowly defined second-language textbook today is ucebnik 'textbook', followed by posobie 'aid', which may be accompanied by adjectives: učebnoe / praktičeskoe posobie 'leaming / practical aid'. It is noteworthy that ućebnik starts to be used actively in the domain of second-language textbooks in the 1870s, as indicated by this title: Élementarnyj učebnik nemeckago jazyka dlja russkago junośestva 'Elementary Textbook of German for the Russian Youth' (Moscow, 1875). Closest in time in the realm of Russian second-language textbooks is NDU 1885. Other possible designations are praktičeskij kurs russkogo jazyka 'practical course in Russian', used for university-level textbooks, or (praktičeskoel ućebnoe) rukovodstvo '(practical / learning) guide'. The umbilical cord between reference grammars and second-language textbooks is visible in terms like praktičeskaja / ućebnaja grammatika 'practical / educational grammar', today never used without the adjective to denote a narrowly defined second-language textbook. Textbooks intended for independent use outside the classroom are called samoucitel' 'self-instructor'. Reading selections may be presented as kniga dlja ćtenija 'book for reading' or xrestomatija 'reader'. The previously frequent term razgovory 'dialogues' is now obsolete together with the genre it represented, 
although dialogues on everyday topics continue to be a staple component of the narrowly defined second-language textbook.

The network of Russian second-language textbooks in their broad functional definition can be considered to be a discursive formation, as it satisfies Foucault's requirements for certain regularity in terms of object, manner of statement, the appearance and dispersion of concepts or the strategic possibilities for thematic choice (Foucault 1972a, 38). The network will be referred from now on as the Second-Language Leaming (SLL) discursive formation. Relevant for our purposes at this stage are the regularities regarding object and manner of statement. We have already determined that the objects of second-language textbooks are a language and its speaking subject and the objects themselves are fairly constant despite variation in their conceptualization, to which we shall return.

In terms of the speaking subject, the realization that national culture should be a major factor for the authors of second-language textbooks predates its reflection in the practice of textbook writing. It becomes noticeable around the middle of the nineteenth century, for instance in the writings of one of the prolific pedagogues of that time, 1. M. Nikolič. RX 1848 is the earliest instance of a textbook that presents a speaking subject with national flavour and therefore automatically subscribes to a model other than the Civilized-World Model, which dominated the stage at this time. Perhaps not accidentally, it is a reading selection and not a narrowly defined Russian second-language textbook.

From the perspective of language, when we move back in time in the familiar ground of second-language textbooks as known to us today we stumble over a threshold that divides the network of textbooks in two groups according to the manner of statement in the metalinguistic part of Russian second-language textbooks. This threshold coincides with the early 1870s and in fact affects statement both in terms of language and speaking subject. Until this time textbooks show no awareness of the cultural specificity of Self and at the same 
time approach second-language teaching in an archaic manner. This is the period for which I had to be extra flexible in my definition of second-language textbook. Textbooks that correspond to modern ideas of second-language teaching appear only afterwards. My earliest example is PRIRJa 1878.

Let us now consider the sources of continuity in the area of the code and more specifically in what we agreed to call Russian as the object language of second-language textbooks. Here one can distinguish between simple repetition and routine. Authors borrow from one another and from third parties larger and smaller sequences of text. Some early examples go back to the seventeenth century and link TW 1680s and GR 1696, among others, to Janua Linguarum by J. A. Comenius (TW 1696, 22-33). The Hanseatic language textbooks in general share many features (LGMSR 1607 I, 19-25). Another example of such borrowings in my collection, which less kindly may have been called plagiarism, was spotted by contemporaries of the author. It was made by Jacob Rodde, who included as a reading selection in RSL 1773 the dialogues on everyday topics in DR 1749, published by Georg Philipp Platz (Bemhagen 1968, 115). Borrowing of this kind is what I shall here call repetition. Repetition lies on the surface and is easy to spot. Here are several examples. Dmitrij Donskoj is reported to have declined the offer to choose the least dangerous place during the 1380 Kulikovo battle with almost the same words by authors separated by more than a century and a half:

(43) Gde vy, tam i ja. Skryvajas' nazadi, mogu li skazat' vam: brat'ja! umrem za otežestvo? Slovo moe da budet delom! Ja vožd' i načal'nik: stanu vperedi i xoč položit' svoju golovu $v$ primer drugim. (RX 1848, 1-4)

'Where you are, there I shall be too.Hidden behind could I say to you "Brothers! Let us die for the
Gde vy, tam i ja! Skryvajas' pozadi, mogu li ja skazat' vam: brat'ja! Umrem za otečestvo? Ja vožd' i načal'nik: stanu vperedi i xoču položit' svoju golovu v primer drugim. (ČRR 1997, 51)

'Where you are, there I shall be too. Hidden behind could I say to you "Brothers! Let us die for 
fatherland"? Let my word become deed. I am the leader and the head. I shall stand up in front and sacrifice myself as an example for others.' the fatherland"? I am the leader and the head. I shall stand up in front and sacrifice myself as an example for others.'

A well-known Imperial-time anecdote is repeated in textbooks of the following period published in the USSR and abroad:

(44) Mužik vezet voz solomy, a drugoj idet emu navstreču. "Zdravstvuj, Ivan!" "Zdravstvuj, Petr! a čto vezeš?" "Seno vezu, xorošee seno." "Kakoe seno? Ved' èto soloma!" "A esli vidiš", čto soloma, tak počemu i sprašivaes'?" (REB 1923, 10)

'Don't ask about what you know A peasant carting a load of straw runs into another. "Hello Ivan!" "Hello Petr! What are you carting?" "Hay, I am carting good hay." "What hay? This is straw." "Well if you see that it is straw, why are you asking?"”
Shutka

Petr vezet voz sena.

Pavel idet emu navstreču.

- Zdravstvuj, Petr.

- Dobroe utro, Pavel.

- A chto vezeš'?

- Drova.

- Kakie drova, ved' èto seno!

- A esli vidiš, cto seno, tak začem sprašivaeš? (Žs 1926, $29)^{13}$

'Joke

Petr is carting a load of hay.

Pavel comes from the opposite direction. "Hello Petr!" "Good moming Pavel!" "What are you carting?" "Wood." "What wood? This is hay." "Well if you see that it is hay, why are you asking?"'

Another example close to our time is the story about Anton's fateful forgetfulness, entitled Ničego ne zabyl '[He] did not forget anything' (RJaV 1976, 116) or alternatively $M y$ ničego ne zabyli 'We did not forget anything' (DDE 1994, 6:58-60). Sometimes the authorship of such texts is noted: for example Mitchel Wilson's short story is given in adaptation in RST 1985, 67-68 as Kak ja obxodilsja bez perevodcika 'How I managed without an interpreter' and in RB 1999, 197-198 as Ja hez perevodčika 'Me without an interpreter'. Some language samples belong to the large group of travelling folklore motifs, which

\footnotetext{
${ }^{13}$ For other versions see RX 1894. 2: RU 1902. 147: RS I 1908. 83; PRG 1938. 177. A verbose variation about a grandmother who is knitting rather than eatting a pie is offered in PKORJa 1913. 85.
} 
wander from one textbook to another and contribute to the field of coexistence of statements in our discursive formation as defined by Foucault (1972a, 57). Examples follow:

(45) Nadobno est' čtoby žit', - a ne žit' ctoby est'. (GTJa 1835, 287)

'It is necessary to eat in order to live and not to live in order to eat.'
My edim, čtoby žit', a ne živem, čtoby est'. (P 2 1996, 50)

'We eat in order to live and do not live in order to eat.'

(46) Slovo ne vorobej, vyletit - ne pojmaes’’! (KC 1888, 21; RB 1999, 199)

'A word is not like a sparrow. Once it has flown out you cannot catch it!'

(47) Pospešiš’, ljudej nasmešiš’ (RR 1 1914, 27; P 2 1996, 15)

'Act rashly and you'll make people laugh.'

(48) Staryj drug lučše novyx dvux. (NSRJa 1875, 51; RB 1999, 354)

'An old friend is better than two new ones.'

(49) Videl tatarin kisel' vo sne, da ložki ne bylo; leg spat' s ložkoj kiselja ne vidal. (PRIRJa 1878, 155)

-A Tatar saw jelly in his dream but there was no spoon. He went to bed with a spoon but saw no jelly.'
Videl Vanja vo sne kisel', da ložki ne bylo. Leg spat's ložkoj - kiselja ne bylo. (ŽS 1926 37; Žs 1929, 77)

'Vanja saw jelly in his dream but there was no spoon. He went to bed with a spoon but there was no jelly.'

Especially interesting is repetition that can be characterized as a slip of tongue made possible by the field of memory that encompasses statements (Foucault 1972a, 58). NIR 2000, 129 cites as part of an exercise on syntax various sentences, among them Molodym vezde u nas doroga 'Young people in our country are given all opportunities', a line from I. O. Dunaevskij's Maršo Rodine 'March about the Native Land' (lyrics by V. I. Lebedev-Kumac), made a hit by the Soviet movie star Ljubov' Orlova in the famous Stalinist propaganda 
movie Cirk 'Circus' (1936, Film Director: G. V. Aleksandrov). This is the same song that proclaims:

Ja drugoj takoj strany ne znaju,/ Gde tak vol'no dyšit čelovek.

'I don't know of another country where a person can breathe as freely.'

A couple of sentences further this memorable quotation is followed by another: Učit'sja, ucit'sja, učit'sja '[The important thing is] to study, study [and] study'. This line comes from the unforgettable speech of V. I. Lenin at the opening of the Third Congress of the Young Communist League, pronounced on October 2, 1920. Lenin goes on to explain why education is so important:

Kommunistom stat' možno liš’ togda, kogda obogatiš svoju pamjat' znaniem vsex tex bogatstv, kotorye vyrabotalo celovecestvo.

'One can become a communist only having enriched one's memory with knowledge of all the treasures that humankind has accumulated.'

M. N. Anikina, the author of this textbook, by no means espouses communist views. Her textbook subscribes to one of the most popular subvarieties of the post-Soviet Common Grounds Model. She simply makes use of bits and pieces stacked industriously at the back of her mind.

In a similar vein. an Imperial textbook involuntarily shows familiarity with the medieval apocryphs, a body of literature frowned upon by the Orthodox Church, in the following slip of the tongue:

(50) Kto ne rodilsja, a umer? (Adam) (PRIRJa 1878, 121)

'Who was not bom but died? Adam.'

This adage coming from Beseda trex syjatitelej 'Conversation among Three Holy Men ${ }^{14}$ was popular enough to have become proverbial (Dal'1880$1882,4: 9)$.

"Two versions of Beseda trex sijatifelej from the fifteenth and the seventeenth centuries respectively, containing this particular exhange on p. 432 and p. 435 . can be found in Tixomirov 1893. 429-438. About the worldview manifested in aperyphal literature in general and in this literary work in particular ef. Mil'kov \& Smol'nikova 1989. 
Even more substantial for the formation of the field of coexistence of statements than the voluntary or involuntary reduplication of shorter or longer fragments is the routine of professional teachers of language, from whose midst the authors of second-language textbooks usually arise. This routine has not always been the same but its goal has been. When one teaches language, one should take care to cover its basic grammar and vocabulary. Some kind of mechanism should be in place to ensure this coverage. It is not a coincidence that systematic grammars predate the narrowly defined second-language textbooks and that they first appeared precisely for this purpose: to teach people to speak a second language. A logical supplement to such a systematic grammar would be a thematic list of words. Indeed, such lists are par of some of the early items in my collection (e.g., DRS 1629, GR 1696, RG 1750, RRG 1827). Leaming lists of words by heart is not an easy task, however. Besides, even if one learns them, it takes considerable extra effort to employ these words if the learner never encounters them in context.

It was discovered early on that the target language should be presented in sentences or larger fragments of text. In the practice of second-language teaching, this approach certainly predates the appearance of systematic grammars, as it imitates the process of first-language acquisition. Many textbooks illustrate this approach. In their pure form they consist of texts, frequently dialogues called razgovory, usually accompanied by a juxtaposed translation (e.g., DR 1749 , NDRG 1792. NREL 1811, NERD 1822). The placement of the Russian text in a column on the left side of the sheet in RHG 1635-1648 clearly indicates that what came to us as a collection of Russian dialogues was meant to be supplemented with a translation and, therefore, belonged to the same genre.

The difficulty was and continues to be how to combine two good but mutually exclusive things: complete coverage of the target language as a system and demonstration of its functioning in context. The attempts to reconcile the paradigmatic and syntagmatic aspects of language determine the essence of 
second-language textbooks as a discursive formation. The first were mechanical: they simply combined under one cover a systematic grammar with a collection of texts (e.g., GR 1696, RG 1750, RSL 1773, ORTPG 1825, RRG 1827). In the last third of the nineteenth century we encounter the first balanced textbooks, prepared after a formula that was to shape the future of the SLL discursive formation. Systematicity follows the patterns discovered in razgovory: it is moved one level up from vocabulary, morphology and syntax and now determines the circle of topics included in second-language textbooks. This is how one can predict that somewhere in any textbook today we'll have a discussion of health, a description of one day in the life of the characters, food, entertainment, travel and so on. Moreover, additional emphasis may be placed on collocability, and vocabulary will frequently be introduced in thematic groups. For example, here is a selection from two textbooks:

(51) Zamkom zamykajut. (DD 1902. 21) 'One locks with a lock.'

(52) Ušami slyšat. (DD 1902, 21) 'One hears with one's ears.'

(53) Doktor lečit. (DD 1902, 27) 'A doctor heals.'

(54) Pastux paset stado. (DD 1902, 27) 'A shepherd tends a herd.'

(55) Svjaščennik soveršaet bogosluženie i poučaet narod. (DD 1902. 27)

'A priest offers liturgy and preaches to the people'

(56) Vodu nosjat vedrami. (DD 1902. 35) 'One carries water with buckets'

(57) Sor podmctajut metloju. (DD 1902. 35) 'Litter is swept with a broom'

(58) Nosom my obonjaem i različaem zapax predmetov (DD 1902. 37)

'We smell with our noses and detect the odour of objects.'

(59) Korova myčit, a lošad' ržct. (DD 1902, 36)

'A cow moos and a horse neighs.'

(60) Korova myčit. (MLR 1938, 1:3) 'A cow moos.' 
(61) Sobaka laet. (MLR 1938, 1:3) 'A dog barks.'

(62) Sčuka plavaet. (MLR 1938, 1:4) 'A pike swims.'

(63) Igloj క’jut. (MLR 1938, 1:4) 'One sews with a needle.'

(64) Gde čto xranjat. Saxar v saxamice. (MLR 1938, 1:59)

'What is kept where. Sugar in the sugar-bowl.'

(65) Iz čego lepjat gorški? (MLR 1938, 1:60) 'What are pots modeled from?'

(66) U kogo kakaja zašcita. U volka - zuby i kogti. (MLR 1938, 1:60)

'Who has what kind of defence? The wolf has teeth and claws'

Such sentences are mnemotechnic devices that package together vocabulary describing the same fragment of reality in the form of truisms. This is the kind of sentence, in conjunction with the basic conversations on a generic theme, that attracted the attention of Eugene Ionesco, inspired him and made him a successful playwright. Here is how he describes his experience:

Nine or ten years ago, in order to leam English, I bought an EnglishFrench conversation manual for beginners. I set to work. I conscientiously copied out phrases from my manual in order to learn them by heart. Then I found, reading them over attentively, that I was learning not English but some very surprising truths: that there are seven days in the week, for example, which I happened to know before; or that the floor is below us. the ceiling above us, another thing that I may well have known before but had never seriously thought about or had forgotten, and suddenly it seemed to me as stupefying as it was indisputably true. [...] For all that, I had not yet reached the point of giving English up. And a good thing too. for after these universal truths the author of my manual passed on from the general to the particular; and in order to do so, he expressed himself, doubtless inspired by the Platonic method, in the form of dialogue. In the third lesson two characters were brought together and I still cannot tell whether they were real or invented: Mr. and Mrs. Smith, an English couple. To my great surprise Mrs. Smith informed her husband that they had several children, that they lived in the outskirts of London, that their name was Smith, that Mr. Smith worked in an office, that they had a maid called Mary, who was English too, that for twenty years they had known 
some friends called Martin, and that their home was a castle because 'An Englishman's home is his castle'. (Ionesco 1964, 181-182)

The ability of a second-language textbook to prompt - when read with a fresh eye - such a striking piece of literature as Ionesco's play La Cantatrice Chauve is the final proof that second-language textbooks are indeed part of a discursive formation with its own specific statements. Communication continues to be the major function of speech in this discursive formation as elsewhere, but the utmost communicative value of the message is not in its connection to such elements of the communicative situation as addresser, addressee or context but in itself. It communicates know-how to be applied in the future to similar communicative situations.

In our sophisticated age textbook authors may go to great lengths to cover up the nuts and bolts of their discursive routine. BR 1981, for instance, introduces an extraterrestrial character Zyuzya, who of course is fully justified to ask lots of silly questions and initiate the right kinds of exchanges.

This routine did not crystallize ovemight. as demonstrated by the groping attempts of individual authors to find altermative solutions for the secondlanguage textbook dilemma, solutions doomed to remain outside the mainstream. Such attempts were made, for instance, in GTJa 1835, PZRJa 1868, NSRJa 1875. KRS s.a. [1890-1899?] and NPEM 1900. I shall illustrate the entire category with RKG 1898, which provides an exotic treatment of the syntagmatic-paradigmatic balance, especially poignant if viewed from the perspective of its later edition RKG 1931, which is emphatically mainstream-oriented. In RKG 1898 the grammatical material is presented in a systematical fashion: in the first part after an introduction to the sounds and their orthography come the nouns with their declensions, then the numerals. the pronouns, the adjectives, the verbs with their conjugations, the adverbs, the prepositions and the interjections. The second part opens with a more in-dcpth overview of the inventory and the combinatorial potential of sounds and then moves on to discuss the word formation and syntax 
of the parts of speech in the same order as in the first part. At the end there are three appendices: Russian proverbs and expressions with German translation; sample letters and readings, some presented anonymously and others with the names of their authors; and finally a German-Russian glossary. This structure identifies the dependence of RKG 1898 on reference grammars for systematicity. Inside every lecture there are, however, exercises that pay tribute to the need for contextualization. Here the reader finds thematic lists of vocabulary, for example parts of the body (RKG 1898, 59), geographic terms (RKG 1898, 69), sentences for translation from and into Russian and dialogic exchanges. Here is a sample of the latter:

(67) Videli li Vy prusskago korolja? Ja videl ego s ego ministrom, knjazem Bismarkom. (RKG 1898, 67)

'Did you see the Prussian king? I saw him with his minister Prince Bismarck'

(68) Mnogo li ubili kabanov $v$ zverince grafa? My ne byli $v$ zverince grafa, my oxotilis' za melkoj dix'ju. (RKG 1898, 79)

'Did you kill many wild boars in the count's menagerie? We were not in the menagerie; we were out hunting for small game.'

(69) Daete li Vy bol'nym koz'e moloko? Ja sam ne oxotnik do koz'jago moloka, no daju ego čaxotočnym. Polezno li ono čaxotočnym? Caxotǒ̌nym ono očen' polezno, oni casto vyzdaravlivajut ot koz'jago moloka. (RKG $1898,79)$

'Do you give goat's milk to the sick? I don't like goat's milk myself but I give it to consumptives. Is it beneficial to consumptives? It is very beneficial to consumptives, they often recover thanks to goat's milk.'

(70) Kotoraja iz ètix devic samaja veselaja? Samaja veselaja iz ètix devic mladšaja doč xromogo kapitana. Otžego on xromaet? On xromaet vsledstvie opasnoj rany $v$ noge, kotoruju on polučil v poslednjuju vojnu. (RKG 1898. 92)

'Which of these maidens is most joyful? The most joyful of these maidens is the youngest daughter of the lame captain. Why is he limping? He is limping because of a serious wound in the leg that he received during the last war.' 
(71) Vidite li Vy ètogo bednogo rebenka? Cto s nim? On byl ukušen bešenoju sobakoju, i verojatno umret ot vodobojazni. (RKG 1898, 145)

'Do you see this poor child? What is the matter with him? He was bitten by a rabid dog and he will probably die of hydrophobia.'

(72) Kak on udostoilsja takix počestej? Vy znaete, čto často durakam sčast'e ulybaetsja, kotoroe bežit ot umnyx. (RKG 1898, 162)

'Why was he conferred such honours? You know that good fortune that shuns away from sman people frequently smiles at fools.'

What distinguishes these dialogues in RKG 1898 is fragmentarity. There seldom is more than one turn of the same conversation before the author moves to a new topic. He is apparently guided only by his imagination in the choice of topics. His sentences describe specific events, many of which are quite extraordinary. In the second part of the textbook, where dialogues become somewhat longer, they continue to have little relevance for the everyday interests of the average person. For instance, one dialogue discusses Hungarian prison conditions and the prison experiences of a nameless Croatian (RKG 1898, 193). Some texts are in fact poems posing as prose: for example, a fable about a spider (RKG 1898, 146) and Dub $i$ trost 'Oak and Reed' (RKG 1898, 156-7). Some sentences for translation appear to have been copied out of Russian fiction. and taken in isolation, they make a strange impression both in terms of overt syntax and of word order. Some examples are the following:

(73) Pritom prepjatstvovala nam nepogoda prodolžat' naše putešestvie. (RKG $1898,160)$

'At that had weather was preventing us from continuing our journey.'

(74) Posemu vixr' slomal vcličestvennyj dub, a trostnik, odnako, on tol'ko prignul k zemle. (RKG 1898, 160)

'Therefore the whirlwind broke the majestic oak whereas the reed, however, only bent to the ground.'

(75) Vdrug zazvenelo u dverej: din', din', din'! i naš čudak vošel, kak budto ni $v$ čem ne byvalo. (RKGi 1898, 164-165) 
'All of a sudden the bell rang at the door: clink, clink, clink! and our weirdo came in as if nothing had happened.'

RKG 1898 clearly demonstrates by contrast the conditions under which contextualization functions in mainstream second-language textbooks: (a) contextualization is oriented to larger chunks of text than the sentence or the turn of utterances and (b) both narrations and dialogues are firmly rooted in the everyday life of the average person.

Illustrations are an imporant feature of the SLL discursive formation. ${ }^{\text {Is }}$ They alone could prove beyond doubt the existence of a specific manner of statement that characterizes the SLL discursive formation. Of course, there are textbooks without illustrations. But second-language textbook illustrations, taken in their entirety, differ from the illustrations in any other kind of book. Illustrations contribute to the achievement of all four goals of second-language teaching: reading, writing, speaking and understanding. Typical illustrations in a Russian second-language textbook include first of all a list of the Russian handwritten letters (see Illustration 1), sometimes even of larger passages, and from time to time samples of different handwritings (as in RKG 1931). This type of visual information has a long tradition in Russian second-language textbooks as LGMSR 1607, I, 561-566: DRS 1629, 16, 173-185; TW 1680s. 2-3 and GR 1696 testify. Some books also provide visual instructions on the sequence in which Russian letters are written (as in NRG 1956,7) and on their links with adjacent letters (see Illustration 2). Since printing is considered unacceptable in Russian culture, an important task of Russian second-language textbooks is to ensure that students can both decipher other people's handwriting and produce their own legible writing. A chart of the Russian handwritten letters on its own as the only graphic in a textbook corresponds to a minimum commitment to employ images as an extra tool towards the achievement of SLL goals. 
Second, many textbooks borrow from phonetics cutaway images of the vocal tract to show graphically the correct articulation of difficult sounds (see Illustration 3). This is the only point of contact between linguistics and the SLL discursive formation in the area of illustrations.

Third, illustrations may provide a parallel channel for explanation of grammar and vocabulary. Two synonymous signs of reality - a visual and a verbal one - are juxtaposed in this case to facilitate the understanding of the verbal sign. Not everything is equally susceptible to such double treatment in which narrative and image mutually clarify each other. Some areas, however, have been dealt with extensively: objective entities denoted by nouns (Illustrations 4 and 5), paronyms (Illustration 6), idiomatic speech (Illustration 7), proverbs (REW 2000, 293) and spatial relations, in particular the spatial meanings of adverbs and prepositions (Illustrations 8 to 10), as well as the verbs of motion (Illustration 11) and the grammaticalized semantic opposition of direction and location (Illustration 12). Vocabulary, phraseology and clichés have been the object of illustrated glossaries and dictionaries for beginners (Illustration 13). In narrowly defined second-language textbooks one can encounter thematic series of pictures entitled, for example. Iz sel'skoj žizni 'From rural life' (RM $1901,42)$ or $I z$ gorodskoj żizni 'From urban life' (RM 1901, 45) or others that illustrate trades and their typical activities such as pormoj 'tailor', prjaxa 'spinner', kuznec 'blacksmith', kak strojat doma 'how houses are built', v kuxne 'in the kitchen' and so on. Pictures may be accompanied by sentences that describe in words the action the person in the picture is performing (Illustrations 14 and 15). An apotheosis of this function of illustrations is GRJaI 2000, which assumes the ambitious task of presenting the Russian grammar in pictures.

Finally, illustrations can be complementary to narrative. Comic strips provide a typical example of this relationship (Illustration 16). Utterances, however, need not be attributed to the speaker in the traditional comic-strip

\footnotetext{
is They have already altracted the attention of scholars, if one is to judge from a PhD dissertation.
} 
fashion (Illustration 17). There also are more subtle forms of complementarity, as one can see in Illustrations 18 and 19.

Illustrations can also be used in exercises on their own as a setting, prompting students to use certain synonymous (Illustrations 20 and 21 ) or complementary (Illustrations 22 to 24 ) verbal signs.

In their relation to the addressee, illustrations can be either overtly prescriptive or descriptive. Descriptive illustrations can be further subdivided into seemingly descriptive and truly descriptive. Examples of prescriptive illustrations are those monitoring handwriting and pronunciation. The message there is clear: do what you see in the picture and you will resemble the natives. The seemingly descriptive messages aim to achieve the same effect by example. As they are dealing with a diversified reality, they can only show instances of correct relation between reality (signified by the picture) and speech, and hope that the readers will follow their lead in the varied situations they will encounter in the future. The SLL discursive formation is characterized with illustrations in which some form of prescriptiveness (be it direct or indirect) is inevitably present. The SLL discursive formation needs no truly descriptive illustrations in order to achieve its goals. Many textbooks however feature truly descriptive illustrations. What is their function? In chapters 5,6 and 7 we shall have occasion to explore the contribution of truly descriptive illustrations to the image of Self that textbook authors wish to project.

To summarize, the overview of sources shows that the greatest divide in terms of Russian second-language textbooks is situated in the 1870s. The transition was gradual, prepared by decades of teaching experience and reflection. When it took place, it was accompanied by the consolidation of the term učebnik as a designation for the narrowly defined second-language textbook. The textbooks that characterize best the time span before the 1870 s

which. however. I have not had the chance to consult (Vorob'eva 1986). 
threshold belong to the Civilized-World Model. In the modern period, the speaking subject acquires national features. This change is in agreement with the public opinion in Russian society at the time, which in 1859, for instance, expected painters to be graždanami svoej strany, a ne kakimi-to ideal'nymi kosmopolitami. bez rodu $i$ plemeni "citizens of their own country rather than some kind of ideal cosmopolites without [attachment to] kith and kin' (Lebedev 1952, 42 quoting Sovremennik, 1859, 7-8, 114). Ionesco-style statements and prescriptive illustrations characterize the balanced modern second-language textbooks. The closest equivalent to the modern narrowly defined secondlanguage textbook in the premodem period is the mechanical combination of its three sources: reference grammars, glossaries and reading selections, comprising dialogues and monologic passages, poetry and prose. 


\section{Authors between Anonymity and Authority}

We can group the authors of second-language textbooks by cultural identity, gender and, most importantly, sources from which they derive their authority. The corollaries of the authors' cultural identities were discussed in detail in chapters 1 and 2. From a gender perspective, it is noticeable that the appearance and the increasingly massive presence of women among the authors of second-language textbooks is a feature of the twentieth century. This tendency probably directly reflects the feminization of the humanities. The first active women I found in the field are Nina Seifertová-Šrutová and Ludmila Šrutová in Czechoslovakia (URJ 1929), Anna Herring Semeonoff in the English-speaking world (BUYR 1933 and FRR 1933) and Vera Nikolaevna Kljueva and S. M. Frumkina in the Soviet Union (LRSDA 1933). Women were involved in secondlanguage production before this time, but their interest in Russian seems to have lagged behind that in other languages: for instance Marija Mixajlovna Bobriščeva-Puškina published Cours théorique et pratique de langue française à l'usage de la jeunesse in St. Petersburg as early as 1894 . If my collection is any indication of the overall picture, it shows that from the total number of 172 authors whose names or initials are known, 62 (or 36.05\%) are identifiable as women and 95 (or $55.23 \%$ ) as men. Figure 2 displays the gender statistics by period of time. 


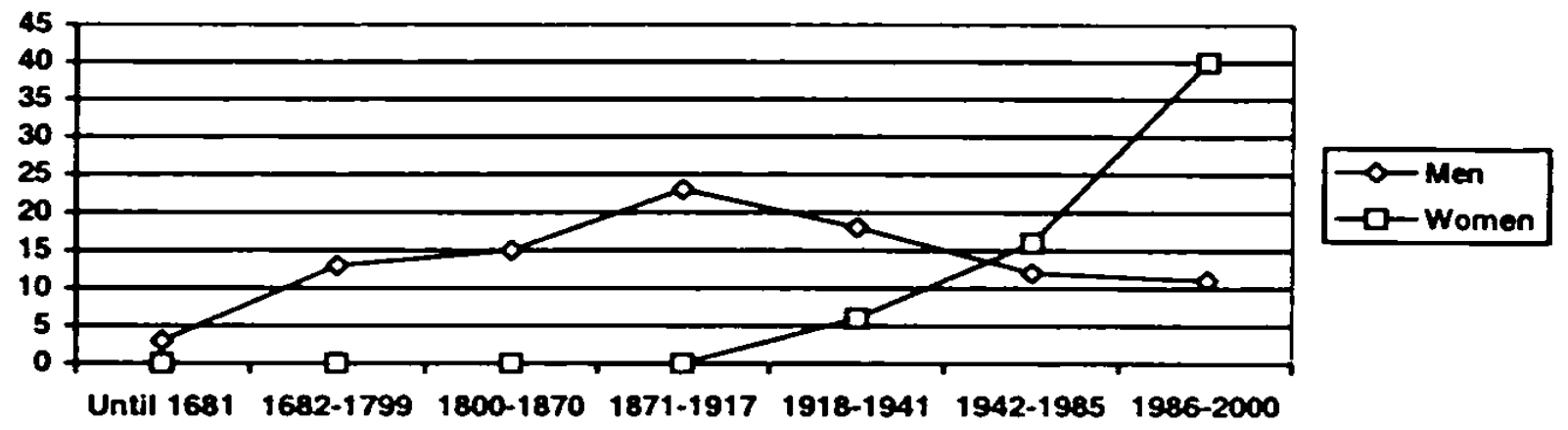

Figure 2. Gender of the Russian second-language textbook authors by period

Thus the first of the prolific periods identified above was the achievement of male authors alone, whereas the second one was due to the concerted effort of both male and female authors with the increasing participation of women as time went by. Interestingly enough, I have not been able to detect any connection between a textbook as a message, its relation to context or code, on one hand, and the gender identity of its author, on the other. The contributions of authors are indistinguishable by gender.

In regard to the sources of authority from which authors can draw, we should turn to the status of author itself, the institutional sites with which an author can associate and the author's relationship to the two objects (Foucault 1972a, 50-53). The necessary but not sufficient condition to teach a language is to know it. Being a native speaker of a language helps convince one's audience that this necessary condition has been fulfilled. The overview of my collection of textbooks identifies the lowest point in the scale of authority required by society from authors. That is the state characterized by the opportunity to prove that one can be an author of a second-language textbook by just being one. This state of affairs would ideally coincide with the anonymity of the author. My collection of textbooks, however, does not provide many examples of pure anonymity.

ERB s.a., RHG 1635-1648 and TW 1680s are unsigned manuscripts, which is nothing exotic in the domain of handwritten culture. MPLR 1952 also has no author and I can offer the following tentative explanation for this 
interesting fact. After World War II, new ideological pressures mounted in Romania to start teaching Russian on a massive scale. Romanian society, however, did not have trained professionals to take on the task. Anybody who knew Russian was welcome to try his or her hand. In the eyes of the intellectually sophisticated Romanian society with its orientation to West European values, those authors' lack of professionalism could not enhance the status of their oeuvre, so their names were omitted.

Alternatively, the author may have used only initials to sign (as in the case of OPUK 1835, PKRJa 1847 and RRJa 1877). The other examples of seemingly anonymous textbooks, such as NERD 1822, RGEM 1876 and HRGS s. a. [1937?] derive their authority from elsewhere: NERD 1822 from its adherence to the teaching method of eighteenth-century author Johann Philipp Wegelin; RGEM 1876 from its compliance with the curriculum of the Ministry of People's Education; and HRGS s. a. [1937?] from the teaching methods developed in the Hugo's Institute for Teaching Foreign Languages in London. These are therefore instances of textbooks that have a single source of authority lying outside the author as a physical person.

It is more common for authors to accumulate authority from several different sources. The most popular among these is the claim that the author possesses a method for teaching the language that would bring results in a short time. This claim exploits the unspoken desires of the audience in the same way in which miraculous cures for incurable diseases and diets find their way to the hearts of those who wish to listen. Among the gurus, whose authority sanctifies not only their own enterprises but also those of numerous imitators against which they take measures of precaution in recent times, are Johann Amos Comenius (1562-1670), Johann Philipp Wegelin, Heinrich Gottfried Ollendorff (1803-1865) and Maximilian Delphinus Berlitz, listed in chronological order. Between the 1890s and the 1970s the publishing house Julius Groos in Heidelberg published dozens of textbooks for different languages (including Russian) compiled 
according to the method of [Thomas] Gaspey - [Emil] Otto - [Karl Marquard] Sauer; this method was diligently announced on every book as being the property of the publisher, who would be grateful if unlawful use of these names for advertisement were brought to his attention.

The benefits accrued from the possession of a reliable method could, however, be undermined by the imperfect knowledge of the target language, as demonstrated in N. A. Dobroljubov's review of PL 1857. I. Pihlemann, the author of PL 1857, applied to Russian the method introduced by Raphael Kühner (1802-1878) in his Elementar Grammatik der lateinischen Sprache mit eingereihten lateinischen und deutschen Übersetzungsaufgaben und einer Sammlung lateinischer Lesestïcke nebst den dazu gehörigen Wönerbüchern (1844), an aspect of his work found praiseworthy by Dobroljubov although the textbook itself was handicapped by lack of complete correspondence to actual Russian speech practice:

Nemcy, kotorye vyučatsja po ètoj grammatike, budut delat' mnogo ošibok protiv Cistoty i pravil'nosti russkoj reči. (Dobroljubov 1962 [1859], 421) ${ }^{16}$

'The Germans who will study by this grammar will commit many infractions of the purity and correctness of Russian speech.'

One obvious answer to the multiple-authority challenge is team authorship in which each team member is associated with one source of authority. As time went by, authors increasingly resorted to this solution: 43 out of 137 textbooks (31.39\%) are the outcome of teamwork, but the first team effort (RX 1872) belongs to the 1870s. Certainly, team authorship may be caused also by other considerations beyond the issue of authority, but its relevance is indubitable.

In view of the twin objects of second-language textbooks (a language and its speaking subject), authors can lean on two further categories of authority:

${ }^{16}$ One wonders how damaging in fact Dobroljubov's critique was if Pihlemann's textbook underwent at least ten editions and must have remained in use in the Baltic schools for more than thirty years. 
standard grammars of the target language and samples produced by exemplary speaking subjects of that language. Indeed, standard grammars are frequently used and also mentioned. Even Ludolf's GR 1696, the first Russian grammar ever, in the presentation of Church Slavonic language data relies on Meletij Smotrickij's 1619 grammar of Church Slavonic entitled Grammatiki Slavenskija pravilnoe Syntagma (Šepeleva 1980), although the fact is not acknowledged directly. Thus already Ludolf's practice splits second-language authors into two groups: (1) authors who work outside the domain of standard grammar; (2) authors who work inside it either tacitly or explicitly. Those of the latter group who realize that they can derive authority from their association with standard grammar make a point of making it public. Thus PKRJa 1847 leans explicitly on N. I. Grec's 1827 Prostrannaja russkaja grammatika and A. X. Vostokov's 1831 Russkaja grammatika: RKG 1898 on F. I. Buslaev's 1870 Učebnik russkoj grammatiki (RKG 1898, iv) and NRG 1935 on A. A. Śaxmatov's 1925 Očerk sovremennogo russkogo literaturnogo jazyka (NRG 1935, 2).

The choice of authority regarding language presentation both in terms of teaching method and linguistic theory can provide valuable insights in the trends of development of the SLL discursive formation, which will remain, however, outside our current sphere of interest. ${ }^{17}$ Much more important for our purposes is the choice of exemplary speakers, made by authors. In his review of Pihlemann's textbook. Dobroljubov explains the non-idiomatic quality of his Russian speech at least partly with his improper choice of exemplary speakers:

Ne iz Puškina, Gogolja, Turgeneva privodit on primery v poslednem svoem kurse, a iz Levandy, Fedora Glinki, Ustrjalova i t.p. Emu, verojatno, neizvestno, čto jazyk Levandy, Fedora Glinki i t.p. soxinitelej otstoit ot russkogo jazyka nastol'ko že, kak i nemeckij... (Dobroljubov 1962 [1859], 420)

'He cites in his latest course not examples from [A. S.] Puškin. [N. V.] Gogol' and [I. S.] Turgenev but from [I. V.] Levanda, Fedor [N.] Glinka. [N. G.] Ustrjalov and so on. He is probably not aware that the language of

17 A possible starting point of inquiry in these directions are the entries "Teaching Methuds" by Fiederike Klippel and "Linguistics" by Werner Hüllen (Byram 2000, 616-621 and 365-370). 
Levanda, Fedor Glinka and other similar compilers is at the same disance from the Russian language as German.'

The speaking subject of the target language can be represented sy a plethora of speakers, the major divide between them being that of generi: vs. specific speakers. Generic speakers are those who (re)produce folklore genres favoured by language teachers, regardless of the audience they target. Most second-language textbooks invariably include more or less ample selections of proverbs. Even the first known to me. Ein Russisch Buch (1546), contains at least one proverb:

(76) Sydye kryuo da Budy prawo. [= Sedi krivo, da sudi pravo.] (Alekseev 1951, 106)

'You may bend when you sit but you should be straight in your judgements.'

Native speakers too are traditionally taught grammar, spelling and punctuation on the basis of proverbs. As Alexej $\mathbf{N}$. Tolstoj writes in his autobiographical novel Detstro Nikity 'Nikita's Childhood' (1919-1920):

... [uzitel' Arkadij Ivanovič] bystro poter ruki, budto by na svete ne bylo bol'šego udovol'stvija, kak rešat' arifmetičeskie zadači i diktovat' poslovicy $i$ pogovorki, ot kotoryx glaza slipajutsja. (Tolstoj 1958, 3:153).

'[The teacher Arkadij Ivanovič] quickly rubbed his hands as if there was in the world no greater pleasure than to solve sums and dictate proverbs and sayings, which make one be hardly able to keep one's eyes open.'

Authors' and teachers' fatal attraction towards folklore, which has bored to death many generations of students, finds a convincing justification if viewed from the perspective of authority. Indeed. the generic speaker is the earliest kind of speaking authority that textbook authors have at their disposal.

The other category, specific speakers, can be further subdivided into ordinary and exemplary speakers of the target language. Most language samples and stories in second-language textbooks will as a rule be produced by their authors as the best-represented ordinary speakers of the target language and. perhaps, by informants whose services authors may have enlisted. Exemplary 
speakers in the narrow sense are those whose names alone add weight to the textbook. To be able to perform their function, exemplary speakers must be cited by name, and this is usually the case. An early instance of the conscious use of the authority of exemplary speakers is ORTPG 1825, which provides several fables by I. A. Krylov. Practitioners in the field were aware of the importance of exemplary speakers. I. M. Nikolič recommends that excerpts from A. S. Puškin, N. V. Gogol, N. A. Polevoj, Count V. A. Sollogub, F. V. Bulgarin and I. I. Panaev, preferably containing opisanija russkago byta 'descriptions of Russian life', be included in textbooks for Germans from the Baltic region (Nikolič 1848, 29-32). No matter how interesting the content, linguistically imperfect samples should not be included in Russian second-language textbooks, insists Nikolic:

Esli uzenik, ne ponimaja samago dela, tol'ko proctet èti periody, to, ja uveren, on edva uspeet perevesti dux, potomu čto oni šeroxovatodolgovjazy, ne govorja uže o tom, čto sploženy koe kak, na propaluju, ne $\checkmark$ duxe $\mathrm{i}$ ne po skladu nastojaščej russkoj reči. $V$ nix net zdravago russkago smysla, progljadyvajušcego obyknovenno $v$ tečenii reð̌i $i$ vyvodax russkago čeloveka. (Nikoliz 1848, 15)

'If a student without understanding the essence just reads these periods, I am sure he will hardly be able to take a breath because they are uneven and lank, let alone that they are joined haphazardly, recklessly, against the spirit and the constitution of authentic Russian speech. They lack the wholesome common sense that usually transpires in the speech and the arguments of a Russian person.'

Anna Semeonoff sprinkles her NRG 1935 with dozens of short excerpts (typically one sentence long) by a whole cohor of exemplary speakers, always named. Here are their names in alphabetical order: S. T. Aksakov, K. D. Bal'mont, A. A. Blok, I. A. Bunin, A. P. Čexov, F. M. Dostoevskij, N. V. Gogol', I. A. Gončarov, M. Gor'kij, A. S. Griboedov, D. V. Grigorovič, P. P. Eršov, A. V. Kol'cov, V. G. Korolenko, I. A. Krylov, M. Ju. Lermontov, A. N. Majkov, S. Ja. Nadson, N. A. Nekrasov, I. S. Nikitin, I. V. Omulevskij, A. Pečerskij, Ja. P. Polonskij, A. S. Puškin, F. I. Tjutčev, L. N. Tolstoj, I. S. Turgenev and V. A. Zukovskij. The list shows Semeonoff's bias in favour of 
poetry and nineteenth-century literature and can serve as a reliable indicator of what it means to be Russian in her opinion.

Among the textbook authors who do not feel a need to buttress their authority with that of exemplary speakers are these who completely ignore them (NERD 1822, RRG 1827, GTJa 1835, SRPJa 1838, SRJa 1869, NSRJa 1875, RS I 1896, RR I 1914) or who use them anonymously (NORJa 1839, PZRJa 1868, $K C$ 1888). It is difficult to decide whether in the latter case an exemplary specific speaking subject is treated as a generic or as an ordinary specific speaker. Alternatively, some authors, especially those who represent the premodern stage in the development of the SLL discursive formation, prefer to lean almost exclusively on exemplary speakers. For instance, KRS s.a. [1890-1899?] offers poems and large prosaic passages by A. S. Puškin, N. A. Nekrasov, I. A. Krylov, I. S. Turgenev and $M$. Ju. Lermontov, accompanied with interlinear German translation, proverbs, several historical anecdotes and very few non-attributed sentences, some of which were apparently compiled by the author and others copied from Russian fiction.

This chapter highlighted how the SLL discursive formation satisfies its declared need in authority in the realms of teaching method, linguistic representation and ideal speaker. In the process, it demonstrated the existence of a partial overlap between SLL and two adjacent discursive formations, the Linguistic discursive formation (through the intermediary of the standard grammars of the target language) and the Identity discursive formation (through the intermediary of the speaking subject). The overlap is due to the coincidence of objects: language is the object both of second-language learning and linguistic reflection, whereas individual human beings are at the same time speaking subjects of a first language and holders of assorted identities. 


\section{Identity and Second-Language Textbooks}

Let us now consider Russian second-language textbooks again as a series of messages conveyed in a code (object language and metalanguage), which, at least in its quality of object language, must necessarily be Russian. Each such message is divisible into two sections that can be labeled everyday talk and commentary, and defined as follows:

Discourse 'uttered' in the course of the day and in casual meetings, and which disappears with the very act which gave rise to it; and those forms of discourse that lie at the origins of a certain number of new verbal acts, which are reiterated, transformed or discussed; in short, discourse which is spoken and remains spoken indefinitely, beyond its formulation, and which remains to be spoken. (Foucault 1972b, 220)

In fact, this classification is valid only to some extent. As pointed out in chapter 3, the uncommented everyday talk has a place in the architectonics of a second-language textbook only as illustration of the kind of language produced by the natives under similar circumstances. Commentary is the sum of narratives provoked by utterances "said once, and conserved because people suspect some hidden secret or wealth lies buried within" (Foucault 1972b, 220). I shall reserve the term of discourse for each such narrative, whose aim is to "reiterate, expound and comment" (Foucault 1972b, 220). The metalinguistic part of a secondlanguage textbook belongs in its entirety to commentary. I shall be concerned here only with metalinguistic commentary that has cultural impon, ${ }^{18}$ like the following:

(77) Das $s$ darf nicht in der gebildeten Gesprächsform gebraucht werden, das Volk gebraucht es aber sehr häufig, um seine Achtung zu bezeugen, wie da-s ja: net-s nein: tak-s so; požalujtes, požalujstas ich bitte; dieses $s$ als Auslaut

\footnotetext{
18 The evidence that the metalinguistic part of second-language textbooks provides for the interaction between the SLL, and the Linguistic discursive formations will not be considered here in spite of its inherent interest.
} 
ist nichts anderes als das abgekürzte sudar' Herr; so heißt eigentlish da-s - da sudar' ja mein Herr; net-s - net sudar' nein, mein Hert u.s.w. (RKG 1898. 200)

'This $s$ should not be used in the sophisticated style but the simple folk use it very often in order to pay respect, as in da-s 'yes'; net-s 'no'; tak-s 'so'; pożalujtes, pożalujstas 'please'. This final $s$ is only the shortened sudar' 'Sir', so that da-s actually means da sudar' 'yes Sir', net-s - net sudar' 'no Sir', etc.'

For another example see (132) later in the text. Any commentary in the object language part of a second-language textbook, on the other hand, can serve as data for this study.

At this point we are theoretically equipped to demarcate discursively the Narrow Common-Ground Model from all other types defined in Table 2. This model ideally contains only uncommented everyday talk in the object language part, which may or may not be supplemented by relevant commentary in the metalinguistic part. One example should be enough to explain what I mean. In 1915 Hugo's Institute for Teaching Foreign Languages in London published a "simplified grammar" of Russian "with the pronunciation of every word exactly imitated". This grammar was subject to revisions and numerous reprints, many of which were issued with no year of publication in Philadelphia and London, sometimes with slight variations in the title. The latest edition known to me is from 1959 and is identical to HRGS s.a. [1937?] and HRGS s.a. [1916?]. None of the editions I saw has the name of the author; however HRGS s.a. [1937?] and HRGS s.a. [1916?] provide on the last and respectively the first page the following information: "The Russian is guaranteed correct, such as is used by the educated classes in Moscow and Petrograd. Every word has been written by an educated Russian University man, and carefully revised by other educated Russians." The blurb, with its significant choice of the 1914-1924 name Petrograd for St. Petersburg, prepares us for an asynchronous view of Russia. Indeed, the text itself in 1937 features the contemporary name of St. Petersburg. Leningrad (HRGS s.a. [1937?], 110) but never the contemporary name of the 
country, which is only referred to as Rossija (HRGS s.a. [1937?], 135) and never as SSSR. Other linguistic markers also depict the author as a Russian émigré with experience of life in Imperial Russia only. His equivalents for 'greet' (HRGS s.a. [1937?], 225), 'policeman' (HRGS s.a. [1937?], 149), 'pen' (HRGS s.a. [1937?], 37), 'eat' (HRGS s.a. [1937?], 71), 'aeroplane' (HRGS s.a. [1937?], 67) as klanjat'sja, gorodovoj, pero, kušat', aéroplan rather than privetstvovat', milicioner, ${ }^{19}$ rucka. ${ }^{20}$ est', ${ }^{21}$ samolet, ${ }^{22}$ respectively, identify him as a person who has lost touch with the current speech practices of his countrymen. After all, he did change the obsolete izvozčik 'cabman' (HRGS s.a. [1916?], 31) to šofer 'taxi driver' (HRGS s.a. [1937?], 31) and conformed to the requirements of the 1918 orthographic reform. What else do we know about the speaking subject of Russian as presented in HRGS s.a. [1937?]? He comes through as a polite, middle to upper-class male urban dweller who has family and friends and lives in a society of unequal distribution of wealth. The data that enable me to make these conclusions is everyday talk of unmistakable Imperial flavour scattered in the textbook, such as these sentences for translation, which are part of every lesson (the English translation follows the original):

(78) Ėta dama moja sestra. 'This lady is my sister.' (HRGS s.a. [1937?], 27)

\footnotetext{
19 Milicija is the law-enforcement agency created in 1917 (RES 1:949) to replace the abolished policija "police". whose constables were known as gorodovye from 1862 to 1917 (RES 1:382).

${ }^{20}$ Rucka lit. 'handle, holder' was initially reserved for a penholder, cf. A v jascike etom cto u tebja? V nem rucki, per'ja, karandaši, rezinka, a vot ešce nożik (REB 1923, 33) 'And what do you keep in this box? In it there are penholders, pens. pencils, an eraser, and here, there is a knife too'. What used to be 'pentolder' has meanwhile generalized its meaning and denotes pen and penholder together. Such a usage was already in place in 1927-1928 (Il'f \& Petrov 1995a. 285). The practice in the Imperial period was the opposite: it had generalized pero pointed quill; pen, split point".

${ }^{2}$ The systematic use of kušat to refer to oneself is in this book apparently a marker of class identity. Usually one only uses it to invite other people to eat. Testimony that many native speakers perceived this usage as inappropriate is available in textbooks dating at least from the end of the nineteenth century (RKG 1898.200). A later concurring testimony is provided in RSC 1940. 109.

22 The term with its obvious folklore associations first surfaced in 1891 in V. A. Tatarinov's project for an aircraft entitled by the inventor Kover-samolet lit. 'rug flying on its own' (Savrov 1994, 30). By the mid-1920s samolet had won the competition with aeroplun and was the preferred term used by those involved in Soviet aircraft construction and the party leadership (Savrov 1994. 320). Eventually, it spread from there to the Soviet population al large.
} 
(79) Znaet li on ètogo gospodina? Da' ètot gospodin ego drug. 'Does he know that gentleman? Yes, this gentleman is his friend.' (HRGS s.a. [1937?], 34)

(80) Čto vy delali u vašego djadi? Ničego; poètomu ja i dovolen. Cem že vy zanimalis'? Kušal xorošo, guljal po parku, spal, kuril sigary (konečno, ne moi, a djadi), igral $v$ futbol. Slovom, ne želal domoj exat'. 'What were you doing at your uncle's? Nothing; that's why I am satisfied. With what then did you occupy yourself? (I) ate well, walked through the park, slept, smoked cigars (of course, not mine but uncle's), played (at) football. In one word, I did not wish to go home.' (HRGS s.a. [1937?], 71)

(81) Dovol'ny li vy kvartiroj i stolom? Komnata u menja dovol'no xorošaja, no kusat' dajut očen' ploxo. 'Are you satisfied with (your) apartments and (with the) food (=table)? I have a fairly good room, but the food is rather poor (=They give very badly to eat).' (HRGS s.a. [1937?], 77)

(82) Pocemy vy xodite tak často $k$ dantistu? 'Why are you going so often to the dentist?' (HRGS s.a. [1937?], 95)

(83) Gospoda, požalujte $v$ stolovuju. 'Gentlemen, come kindly to the dining room' (HRGS s.a. [1937?], 127)

(84) Moj brat zanjat do semi $v$ kontore. 'My brother is busy till seven in the office.' (HRGS s.a. [1937?], 141)

(85) Ja polučil soveršenno neožidanno dolžnost' upravljajuščego saxamym zavodom $v$ provincii. 'I received quite unexpectedly a situation of a manager in a sugar refinery in the province(s).' (HRGS s.a. [1937?], 170)

The only utterance that belongs to commentary is a proverb specifically identified as such:

(86) Celovek seet, a veter veet. 'The man sows, and the wind blows.' (HRGS s.a. [1937?], 199)

Russian high culture is present in the fleeting mention of the names Cexov,

Dostoevskij, Turgenev, Puškin and Cajkovskij, as in this typical sentence:

(87) Kem napisana opera "Pikovaja dama"? Sjužet Puškinym, a muzyka Cajkovskiim. 'By whom is written the opera "Qucen of Spades"? The plot by Pushkin and the music by Tchaikovsky.' (HRGS s.a. [1937?], 205) 
Russian historical personalities are limited to Peter I, cf. pri care Petre. and Orthodoxy to Christmas, cf. pered Rożdestvom (HRGS s.a. [1937?], 133). Culturally relevant metalinguistic commentary is restricted to patronymics (HRGS s.a. [1937?], 210).

In terms of illustrations, the Narrow Common-Ground Model can choose between dispensing with them altogether and limiting them to those strictly necessary from the point of view of the SLL discursive formation. If available, such illustrations may present humans schematically, depriving them of cultural identity and any individual features (Illustration 25), and in extreme cases, even of gender and age identity. Close to this ideal is the collection of school posters devoted to the Russian case system (RP [1978?]).

This is how the avoidance of commentary, which may have been caused by pedagogical considerations, automatically pours out into the image of Self, characteristic of the Narrow Common-Ground Model. Other textbooks in my collection that subscribe to the same model are RS I 1896, RU 1909, FSR s.a. [1918?], DDE 1994, KK 2000 and REW 2000. What makes the Narrow Common-Ground Model attractive to teachers? In an attempt to simplify for their students the formidable task of dealing with an exotic speaking subject of a no less exotic target language, many teachers (at least in the English-speaking world) may entertain the thought that at the beginners' level a textbook is best advised to keep to essentials, that is to everyday talk. Commentary requires extra effort to be understood properly. As my first-hand experience with proverbs of a transparent and accessible linguistic form such as Golod ne terka 'Hunger is not [like] an aunt', Popytka ne pyrka 'Trying is not torture' and Serdce ne kamen' 'A hear is not [made of] stone' shows, their interpretation by students is associated with considerable difficulty. My literal translations of the proverbs can serve as a sufficient proof of the hiatus between expression and content, which would have been easier to bridge in context than outside of context. Such a context at the beginners' level, however, can hardly be verbal. 
The peculiarities of the Ethnocentric Outsider Model are also due to a specific relation of everyday talk to commentary. Whereas the everyday talk in this type of textbook is close to the original, the commentary comes in translation. It represents discourses circulating in the society of the author and not in the society of the speakers of the target language. Thus, readers are fed the image of a hybrid speaking subject: linguistically fluent and culturally exotic.

Unless a textbook written by an insider embraces the Narrow CommonGround Model, the commentary in the object language part necessarily draws on relevant discourses employed in society. Any attempt to go beyond the "purist" language-dominated presentation of the speaking subject makes the author dependent on the identity discourses of the target society both in the choice of narrative and image. When the goal is to present the speaking subject as a fullfledged human being, commentary inevitably showcases the concomitance of statements between different discursive formations (Foucault 1972a, 58). This goal also shapes authors' approaches to illustrations. Descriptive illustrations help carry across more of the human nature of the speaking subject than commentary alone could do. We already saw in chapter 3 that from the point of view of the SLL discursive formation there is no intrinsic reason to include descriptive illustrations in second-language textbooks. Their abundance alone should alert us that authors set themselves other goals beyond the teaching of a second language. Descriptive illustrations can be of two varieties: illustrations that depict life and illustrations that reproduce ar. The former category can be represented by photos or book graphics commissioned specifically for the textbook. The latter category, which in parallel to exemplary speakers can be dubbed exemplary images, is represented by reproductions of masterpieces of an. It is difficult to draw a clear-cut line between the two subcategories of descriptive illustrations. The contribution of the commissioned an sometimes goes beyond the matter-of-fact depiction of life. The memorable artistic individuality of such 
artists as A. Alekseev (RJaSI 1970), Andrej Štapauk (TNM 1994) and V. Karasyov (ŽMRR 1991; RB 1999), as one can see from their work reproduced here (see Illustrations $11,13,21,22,42,44,52$ ), adds to the image of Russia that the textbook creates for its readership, a dimension impossible to overlook.

Thus, in the area of illustrations we can detect the same three divisions: generic (those justified in the framework of the SLL discursive formation, Illustration 26), ordinary (images of the world, in which the target language is spoken, Illustration 27) and exemplary illustrations (images authorized by the prestige of the artist, Illustration 28). The genericity of the first group of illustrations is in fact a minimalist requirement: they do not have to be generic but they could serve their purpose even if they were. Statistically, the third group of illustrations is the least frequent. Textbooks that do have illustrations usually resort to some combination of generic and ordinary images.

It is time now to explore the concomitance of statements between the SLL and the Identity discursive formations. A discursive formation contains a constellation of competing, correlating and complementary themes or theories (Foucault 1972a, 64). We agreed above to call discourse each coherent subdivision of a discursive formation. Regarding the Identity discursive formation. discourse is the set of beliefs, ideas and principles expressed verbally or nonverbally by which people structure their identity. It also provides matching labels for relevant events, objects and persons, a (frequently implicit) theory for explaining actions and relationships, and a repertoire of justifications and explanations. $^{23}$

The dichotomy of commentary and discourse parallels that of the Saussurean parole and langue. Invariant discourses are realized within a range of variation in commentary. Moreover, a variety of competing discourses function

\footnotetext{
${ }^{23}$ Although it was tempting to adopt for what I call here 'discourse' Michel Foucault's term doctrine "a single ensemble of discourse". which can be religious, political or philosophical among other things. I decided against it because. targeting the mutual interdependence between speakers and the spoken. presented as "dual subjection". doctrine has a different emphasis
} 
simultaneously in society. The same events, objects and persons may get different labels and interpretations within different discourses. Labeling is not an innocent act, but an act of power because the label chosen leads to certain consequences: it exerts social constraint on individual behaviour. Needless to say, the corresponding theories for explaining actions and relationships and the repertoires of justifications and explanations may also be at variance.

At any time, discourses occupy structurally unequal positions in society, which deprives people of the possibility to make their own free choice of discourse. Discourses are rarely explicitly discussed although they are recognizable to members of society through the use of particular concepts, phrases and modes of explanation, and especially key symbols, in Sherry Ortner's understanding of the term (Orner 1973). A Russian literary example shows both the lack of freedom in the choice of discourse as well as the mechanism through which insiders attribute individual utterances to discourses. In chapter 9 of their novel The Golden Calf, Il'ja Il'f and Evgenij Petrov dcpict an old man who tries to make a living in Soviet Russia at the end of the 1920s and the beginning of the 1930 s by creating charades, puzzles and rebuses, which he offers to various newspapers and magazines. His ignorance of the new discursive practices makes his creations unacceptable. Rephrasing a tragicomic story in discursive terms, we could say that inadmissible at this junction of Soviet history are charades that touch upon religion and mystics (key phrases Bog 'God' and rok 'fate', respectively), ethnic identification (Katz may not be recognized as a typical Jewish last name) and the credo of the Bolsheviks' political rivals, such as the Socialist Revolutionaries, recognizable by their slogan $V$ bor'be obretes' 'ty pravo svoe 'You will achieve your rights in struggle'. Welcome is focus on industrializacija 'industrialization,' classification of people according to party membership into partijcy 'members of the Bolshevik party.' bespartijnye 'people with no Bolshevik affiliation' and komsomol'cy 'members of the Young 
Communist League'; and open or veiled praise of Soviet authority (Il'f \& Petrov 1995b, 87-92).

Discourses rarely appear in pure form: not only are different discourses alternatively applied to the same situation by different parties, but the same person may use elements that belong to various competing discourses depending on circumstances. Competing discourses are "the locus of 'a management of meaning' by which culture is generated and maintained, transmitted and received, applied, exhibited, remembered, scrutinized, and experimented with" (Holy 1996, 5).

There seems to be interdependence between discourse and social role. People will not, obviously, reach for different discourses at random but in accordance with their current role. I do not imply that each role has its own discourse, but rather that the range of available discourses is restricted by the current role of that individual. Textbook authors adopt the stance of an authority on a language and by the same token a mediator in cross-cultural contact, a stance that constrains them to follow the chosen discourse with consistency. This is what makes language textbooks an excellent source for the study of identity discourses in a "pure" form. Of course, roles are defined differently in different societies at different times: Russians do not see the role of textbook authors in the same way as Americans, and Soviet Russians see it rather differently from postSoviet Russians. But no matter how it is defined, the cultural mediator role will restrict its incumbents in their usage of discourses. Other discourses will as a rule appear as easily distinguishable quotations, if at all. Competition of discourses can be observed, therefore, mainly if one compares different textbooks. A rare example of a textbook that deliberately presents a range of perspectives, which the authors do not share, is REB 1938. Edgar Spinkler, one of the co-authors. explains in the preface that the argument of practical usefulness has dominated the selection of readings. He recommends that his readers consult books by the

(Wetherell \& Potter 1988). 
spouses Ivan and Tamara Solonevic ${ }^{24}$ if they want to get truthful information about Soviet social reality, and he even includes an excerpt from one of them in his textbook. But he also includes passages from pre-Soviet and Soviet sources that convey different messages:

Der Abschnitt aus Dostojewskijs "Tagebuch eines Scriftstellers" (§ 40) über das Russentum möge dem Russisch treibenden Deutschen ein kleiner Hinweis sein auf die uns so fremd anmutenden Wesenzüge des Russen und, aus dem Gegensatz heraus, den Deutschen seine eigene Wesensart klarer empfinden lassen. Die Zeit der Tolstoi- und Dostojewskij-Schwärmerei ist hoffentlich für immer vorbei. [...] In welchem Lichte Sowjetrußland die Zustände bei sich in den Augen der Leser erscheinen lassen will, zeigen die beiden Abschnitte $\S 14$ und 30. Der Vermerk neben der Überschrift: "Aus einem sowjetrussischen Lehrbuch" soll ein Hinweis sein, daß hier nicht objektive Wahrheit vermittelt wird. Die Aufnahme der beiden Stücke erfolgte aus sprachlichen Gründen. (REB 1938, 3-5)

'Let the excerpt from Dostoevsky's A Writer's Diary ( $\$ 40)$ about Russians be for the Germans learning Russian a small clue to the basic characteristics of the Russian that are so alien to us and by contrast make the Germans feel more clearly their own nature. The time of Tolstoy and Dostoevsky's fanaticism has hopefully definitively passed away. [...] Two passages, $\$ 14$ and 30, show in what light Soviet Russia wishes to present to the reader its situation. The remark From a Soviet Russian Textbook by the title of a reading should be a sign that it does not represent the objective truth. The two readings were included for linguistic reasons.'

So, which identity discourses are available to the readership of Russian second-language textbooks and what is their relationship to the range of discourses produced in Russian society? This question will receive different answers depending on the historical period envisaged, but all discursive models can be classified as either orthodox (if they defend the status quo) or heterodox (if they oppose the status quo) (Bourdieu 1995, 168-169). As we look at the

\footnotetext{
${ }^{24}$ The books were published around the same time in Russian and German. Here is the earliest German edition: Iwan Solonewitsch Die Verlorenen - eine Chronik namenosen Leidens in den Zwansarbeitslagern Sowjetrußlands (Essen: Essener Verlagsanstalt. 1937) and Tamara Solonewitsch Hinter den Kulissen der Sowjetpropaganda - Erlebnisse einer sowjerischen Dolmetscherin (Essen: Essener Verlagsanstalt, 1937).
} 
peculiarities of different identity discourses, we shall try to link them not only to the narratives but also to the images of Russian second-language textbroks.

The Imperial period boasts both orthodox and heterodox discourses. The orthodox discourse of the time revolves around the three cardinal ideological principles, "Orthodoxy, Autocracy and Nationality", explicitly formulated by S. S. Uvarov in 1832 and promoted by him while he was Minister of Education from 1833 to 1849 (Riasanovsky 1961, 73-183). This is the shortest explicit wording of the Autocratic discourse in second-language textbooks:

(88) Bez Boga svet ne stoit, bez Carja zemlja ne pravitsja. Bez Carja narod sirota. (RS II 1908, 101)

'Without God the world cannot exist. Without the Tsar the country cannot be governed. Without the Tsar the nation remains an orphan.'

Since Autocracy is the central principle of this discourse, its importance is projected back to the beginnings of Russian statehood. According to the legend, the Varangian princes were invited to rule over Russia with the following words:

(89) Zemlja naša velika i obil'na, a porjadka $v$ nej net, pridite knjažit' i vladet' nami. (RS III 1907, 137)

'Our land is large and abundant but there is no order in it. Come to govern us and be our masters.'

The heterodox discourses of the Slavophiles and the Westemizers emerged later, in the 1840s, in opposition to the orthodox discourse and to each other. Somewhat later Westernizers split into Liberals and Socialists (Malia 1961, 313-334). The Bolsheviks and their rivals sprang into existence from the latter.

It is remarkable that I did not discover any Imperial textbooks that espoused heterodox discourses. The only trace of Imperial heterodoxy that I found is either an Aesopian hint or the involuntary effect of the field of memory, similar to those discussed in chapter 3. In RU 1902, an otherwise convincing example of the Narrow Common-Ground Model (which by the way was 
published in Russia by M. O. Vol'f's Industrial and Commercial Society), we encounter the following exchange in one of the exercises:

(90) Gospodin Palkin, skažite mne Vaše imja! Moe imja Nikolaj. (RU 1902. 41)

'Mr. Palkin tell me your Christian name! My name is Nikolaj.'

As we know, Nikolaj Palkin was the nickname of Nicholas 1, from palka 'stick' motivated with the cruel corporal punishments in the army that were the norm under his rule. This nickname is a marker of heterodoxy that could fit in with any of the Imperial heterodox discourses. We can realize how offensive it was from the perspective of the orthodox Autocratic discourse if we consider that L. N. Tolstoj's 1886-1887 essay entitled "Nikolaj Palkin", with its passionate critique of the violent measures to which autocracy routinely resorted, was never printed in Russia before the 1917 Revolution (Tolstoj 1964, 595-604).

Traces of Imperial heterodoxy can, however, be detected in the Soviet period in textbooks published outside Russia: for instance, in RKG 1931. On one hand, this textbook does not side with the sympathetic treatment of mass revolt typical of the Communist discourse, which hails leaders of popular upheaval such as Stepan Razin and Emel'jan Pugačev as forenunners:

(91) Pugačeva kaznili posle mučitel'noj pytki. Poslovica govorit: sobake sobac'ja smert' (RKG 1931, 115)

'Pugačev was executed after severe torture. The proverb says: cur's death for a cur.'

On the other hand, its view of Russian history, expressed in a short sketch written by Nikolaj Mixajlovic Bubnov specifically for the textbook (RKG 1931 . iii, 182-183, 186-187, 190-191, 195-196), comes through as an instance of Westernizer discourse. Rephrasing Martin Malia, we can say that the syntagmatic relations between two symbols - Peter I and autocracy - are the diagnostic that distinguishes between the three Imperial discourses: the Autocratic, the Westemizer and the Slavophile. A positive evaluation of both Peter I and 
autocracy is a marker of the Autocratic discourse. The juxtaposition of a positive view of Peter I and a critique of monarchy gives the Westernizer discourse away, whereas the Slavophile discourse is characterized by a negative view of Peter I in conjunction with a critical stance towards monarchy (Malia 1961, 282-284). The only textbook that gives a clear idea of the controversy around Peter's personality is V 21991,28 , which is in tune with its pluralist outlook. Textbooks adhering to the Autocratic discourse omit to mention that not all Russians unanimously supported Peter (for instance, RS III 1907, 152-153). Bubnov positively evaluates Peter's activity and defines its major goal as sbliženie Rossii s obrazovannymi evropejskimi narodami 'rapprochement of Russia with the educated European nations'. Then he remarks:

(92) Reformy Petra I osobenno ego vmešatel'stvo v obščestvennuju i semejnuju žizn', ego popytki izmenit' narodnye nravy i obyčai na zapadnoevropejskij lad mnogimi vstrečalis' nesočuvstvenno. Priveržency stariny protivilis' vvedeniju novyx porjadkov i vozbuždali k Petru narodnuju nenavist'. Petr strogo presledoval oslušnikov svoej voli i žestoko nakazyval ix. (RKG 1931, 190)

'Peter I's reforms, especially his interference in social and family life, his attempt to change people's dispositions and customs according to West European fashion, were met by many without sympathy. The adherents of tradition opposed the introduction of the new usages and stirred people's hatred for Peter. Peter relentlessly persecuted those who disobeyed his will and punished them harshly.'

The activity of the next monarchs is appraised according to their attitude towards Peter's reforms. The ones that continued acting in Peter's vein are high up in the hierarchy. The lowest rung is occupied by Nicholas I, of whom we are told the following:

(93) Carstvovanie ego brata Nikolaja I, načavšeesja usmireniem mjateža 14-go dekabrja 1825 goda, bylo vremenem vnutrennej reakcii, neuklonnoj bor'by pravitel'stva so vsemi projavlenijami svobodnoj mysli i svobodnoj obščestvennoj dejatel'nosti. Ono končilos' neudačnoj dlja Rossii Krymskoj vojnoj (1853-1856). (RKG 1931, 195) 
'Having started with the suppression of the mutiny on December 14, 1825 . the rule of his brother Nicholas I was a time of internal reaction and unrelenting struggle of the government with any manifestations of free thought and free social activity. It ended with the Crimean war (1853-1856), which was unsuccessful for Russia.'

The end of the monarchy is described in a neutral tone and presented as the logical outcome of the events that took place under the reign of the last emperor, Nicholas II (RKG 1931, 196).

This textbook also demonstrates the possibility that there is a time lag between the current discourses in society and discourses reflected in textbooks. It is significant that heterodoxy was reflected in second-language textbooks only at a place and a time in which it had lost its relevance.

Back to orthodoxy in the Imperial period, we consider RX 1848, RX 1872, KC 1888, RS III 1898, RM 1904 and RR III 1914 typical Proselytizing representatives of the Autocratic discourse. An image that represents this discourse visually is the allegory of Autocracy included in RS 11908 (see Illustration 29). In textbooks of the Broad Common-Ground Model, the Autocratic discourse is present only to the extent to which it was reflected in everyday life. Typical are passages like (94), featuring the everyday practice of Orthodox Christianity, or (95), which is a verbal expression of the habitual outward sign of the veneration of autocracy, visually available in images like Illustration 30 .

(94) V devjat' časov Vanja prišel v školu. Razdalsja zvonok. Uと̌eniki voß̌li v klass. Každyj zanjal svoe mesto. Vošel ucitel'. Učeniki vstali i poklonilis' emu. Odin učenik gromko procital molitvu; drugie ee vyslušali. Potom načalos' učenie. Učeniki učilis' pisat', citat', sčitat', pet' i risovat'. Posle učenija opjat' pročitali molitvu, i učeniki pošli domoj. (RM 1901, 77)

'Vanja came to school at nine o'clock. The bell rang. The schoolboys entered the classroom. Everybody sat in his place. The teacher came in. The schoolboys stood up and bowed to him. One pupil recited out loud the prayer; the others listened. Then the classes began. The pupils were learning how to 
write, read, compute, sing and draw. After classes the prayer was read again and the pupils went home.'

(95) Naš klass pomešcaetsja $v$ bol'šoj, svetloj komnate. $V$ ėtoj komnate est' pol, potolok i čtyre steny. Potolok vybelen. Pol vykrašen želtoju kraskoju. Steny obity obojami. Na perednej stene visit portret Gosudarja Imperatora. V odnom uglu stoit pečka, $v$ drugom - skaf dlja učebnyx veščej, a v tret'em klassnaja doska. Posredi klassa stojat skamejki dlja ucenikov. Pered skamejkami stojat kafedra i stul dlja ucitelja. (RM 1901, 77-78)

'Our class is situated in a big room, full of light. In this room there is a floor, a ceiling and four walls. The ceiling is whitened. The floor is painted yellow. The walls are covered with wallpaper. The portrait of His Majesty the Emperor hangs on the front wall. In one comer there is a stove, in the other a closet for the class property and in the third - the blackboard. In the middle of the room there are benches for the pupils. In front of the benches there is a rostrum and a chair for the teacher.'

In other words, the difference between the Proselytizing and the Broad Common-Ground Models is in the kind of commentary they favour: direct in the former model and indirect in the latter. Examples of the Autocratic Broad Common-Ground Model are RX 1894, RAPP 1898, RS II 1898 and RM 1901.

The Soviet period displays an even greater unanimity. Its own orthodox Communist discourse (as presented in brief by Armstrong 1978, 27-51) was paramount in all spheres of social life. The hierarchically structured Communist pary, armed with the only correct social theory in the world, had seized power on behalf of the proletariat in the course of a socialist revolution and was guiding its flock to the imminent heaven on Earth. "Dictatorship of the proletariat" was the socialist stage of development, which was to lead eventually to the establishment of communism. Soviet people were to do whatever it took to facilitate the advance towards communism. Private life was completely subordinated to this task. People had no private concerns because the party had already taken care of everything. The personal propeny that continued existing as an atavism would be eliminated in the future, and the communist principle of distribution ("work according to your abilities and receive benefits according to your needs") would 
triumph. The Soviet way of life and the promotion of the rules of communist conduct were to lead to the appearance of a new type of personality worthy to live in communist society. Meanwhile, however, the Soviet people were surrounded by a swarm of internal and external enemies who could not reconcile with their inevitable defeat. No effor could be spared to fight them.

Outside the private sphere, heterodoxy challenging the orthodox discourse could be heard only from independent rostra abroad. It is represented in my collection by AR 1980 and BR 1981.Textbooks published in the USSR reflected by necessity the Communist discourse in its fluctuation over time. Typical proselytizing examples are RESW 1933, LRSDA 1933, RT 1935, MPLR 1952. RJa 1952 and URJa 1973. Officially, the existence itself of a variety of discourses within Soviet society was disclaimed. In Bourdieu's terms, Soviettime Communist discourse was striving to function in the doxic mode. There were groups of the population for which that indeed was the case, whereas others (a minority?) were aware of the existing critical opinions and were forced to take sides by adhering to an orthodox or heterodox Communist discourse. The pseudo-doxic mode was not adopted in textbooks written by Russian first-wave émigré authors and foreigners. The latter had of course a cross-cultural perspective. Only they were willing to place the Russian experience in a broader context and combine recognition of the current historical transformations of the country with a three-dimensional image of its history. Examples of this so-called Reconciliatory group of the Broad Common-Ground textbooks are RKG 1931, NRG 1935 and CR 1948. The Communist Broad Common-Ground Model is instantiated in ŻS 1926, ŽS 1929, MLR 1938, RTRL 1945, RMLR 1947, RJalS 1974 and RJaV 1976.

Gorbachev's glasnost' brought to the surface of social life a previously submerged variety of discourses and opened the door for the varied opinions of the post-Soviet era. Again, most influential is the orthodox discourse of the time. which I have decided to call the Bridging discourse because it tries to restore 
cultural continuity, which was deliberately disrupted during the previous period. One can hear in it echoes of the Imperial Westernizer and Slavophile discourses. The Bridging discourse is discemible in RREG 1992 and in the reader of RJaV 1995, representatives of the Proselytizing Model. It is also present in textbooks of the Bridging Broad Common-Ground Model such as RJaV 1995 (in the textbook itself), DGR 2000 and NIR 2000. The Communist and Patriotic heterodox discourses are as such poorly represented in textbooks, although the former has its fair share of representation in the form of residue. A good example of this approach is offered by RB 1999, an instance of the Reconciliatory BroadCommon Ground Model of the post-Soviet period.

Are identity discourses equally visible in all types of second-language textbooks? The expectation is that some types of textbooks would be a better platform for the presentation of identity discourses than others, although all of them except the Narrow Common-Ground Model and the Ethnocentric Outsider Model should be influenced to some extent by them. Most explicit should be the presence of identity discourses in the Proselytizing and the Broad CommonGround Models. Discourses can find limited exposure in textbooks of the Cooped-Up Insider Model, perhaps more through what they choose to omit than what they state, as we shall see in chapter 7 . Only one of the outsider models (the Cross-Cultural Comparative Model) can be trusted to show awareness of the Identity discourses functioning in Russian society.

The relationship between the Identity discursive formation and textbooks of the Civilized-World Model is of a different nature. These textbooks equate Self with the prototypical human being and thus promote blindness to cultural variation inside the civilized world. No textbooks subscribing to this model that $I$ have seen have illustrations. From the perspective of the identity discourses known to us in the modern period, these textbooks exist in a pre-discursive universe of the undisputed naturalized image of Self. In Bourdieu's terms, the 
premodem Civilized-World Model is in the doxic mode, as it adheres "to the world of tradition experienced as a 'natural world' and taken for granted" (Bourdieu 1995, 164). The Civilized-World Model is rooted in the West European doxa about civilization, whose essence and refinement over time were explored by Norbert Elias (1969). When, starting with Aleksej Mixajlovič's rule in the second half of the seventeenth century, it was introduced to Russia to be transplanted definitively onto Russian soil with the efforts of his son Peter I, it ousted from the upper social circles the Muscovite perception of Self, as illustrated in Archpriest Avvakum's writings, for instance, and especially in his Life Written by Himself (Brostom 1979). An appropriate label for this Muscovite pre-discursive world of Orthodox Christian tradition would be Svjataja Rus. 'Holy Rus', a self-designation preserved in folklore long after the Muscovite period (Potebnja 1968, 137-139; Solov'ev 1927, 91: Solovjev 1954). ${ }^{25}$ The detailed exploration of the Muscovite doxa would take a whole study. An outline of its development over time and its impact on the Slavophile discourse can be found in Solov'ev 1927. I shall mention here only one of its linguistic signs, the remarkable Russian word for peasant krest'janin, lit. 'Christian', known in its contemporary meaning since the end of the fourteenth century (Vasmer 19861987, 2:374-375). This term does not oppose Russian peasants to non-peasants as Christians to pagans. The direction of the semantic evolution of this Selfidentification from a broad supra-national label to a name for the lowest social class in medieval Russia defines for us the vantage point of the name-givers: it is them, peasants, who do not feel the need to create for themselves a separate social Self-identification label. They keep the universal zero-label 'Christian' at a time when the upper social classes and groups have received a designation each. The process follows the scenario mentioned above in connection with russkij: Self needs no special name, Others need such names. Only after all these new

\footnotetext{
${ }^{25}$ It is worth mentioning that the appearance of the term $S_{\text {vijatcia }}$ Rus $^{\circ}$ is, as A. A. Potebnja notes. the outcome of folk etymology: the initial self-centred svétü-Rus ' 'world-Russia' equating Russia with the universe was only later reinterpreted in the spirit of Orthodoxy as 'Holy Russia'.
} 
names have become customary does krest'janin by contrast also acquire a social rather than denominational meaning. Thus krest'janin places Orthodox Christianity at the epicentre of the process of social division and demonstrates linguistically that Christianity was the common denominator, the source of the general identity, encompassing all social strata in Medieval Russia.

The Holy-Rus doxa was the Russia-specific evolution of general Slavic tendencies. A snapshot of those is offered by Nikita I. Tolstoj on the basis of Nestor's twelfth-century chronicle. N. I. Tolstoj reconstructs for the Slavic world from the ninth to the twelfth centuries a hierarchy of identities based on religion, tribe union, tribe, sub-tribe and, finally, state. Overarching these was the religious identity. Apparently, being Slav (the level of the tribe union) and being Viatichian, Krivichian, Polianian and so on (the level of the sub-tribe) was more important than being Russian (the tribe level) (Tolstoj 1993).

It was the coexistence of two doxas in one society that created in Russia the alienation between its higher and better-educated layers and the broad masses, which has been described so many times (e.g., Fedotov 1967, 71-122). Bourdieu assumes that as soon as alternative opinions regarding an issue appear in a society it steps into the universe of discourse, and doxa is replaced by orthodoxy that shares the limelight with heterodoxy (Bourdieu 1995, 168-169). The case of Russia helps fine-tune his theory. Since the Civilized-World doxa was imposed on Russians from above with the absolute positive Self-assessment already attached to it, there was no dialogue between the supporters of the old and the new views that each claimed the same absolute quality. In Basil Bernstein's terms (1971), while operating predominantly within a restricted code of communication, Russian society was divided into two sections. It took several generations for society in its higher and better-educated strata to bring the new Civilized-World doxa into the universe of discourse, or, in other words, to acquire an elaborated code of communication. By that time the old Holy-Rus 
doxa had been virtually forgotten in the social strata, which were entering the universe of discourse.

My collection of Russian second-language textbooks includes only one belated item adhering to the pre-discursive Holy-Rus Model: NORJa 1839. If the Holy Rus was teaching anybody Russian (and we know it was because this was a time of expansion into vast areas populated by speakers of other languages), it was not using special textbooks to do it. ${ }^{26}$ Moreover, what is known about the medieval attitudes to second-language acquisition, grammar and the relationship between content and its linguistic form makes the production of Russian secondlanguage textbooks at the heyday of the Holy-Rus doxa in Muscovy improbable in spite of the positive evaluation of the effect that the knowledge of Russian (or Church Slavonic) can have on non-Russians (Pekarskij 1862, 1:186-197; Uspenskij 1992, 100-113), in the terminology of the day inostranec, inorodec or inozemec, lit. 'one who originates from another land'. Textbooks for most ethnic groups with which Russians come in contact inside the empire would appear later, and they would belong to the modern period with the consequence that it is its orthodox and heterodox discourses that we can expect to find in them.

In other words, in comparison with the textbook models of the modem period, the Civilized-World and the Holy-Rus Models feature different discursive characteristics. Both appear as pre-discursive when viewed from the perspective of the Identity discursive formation because they function in doxic mode outside the universe of discourse. Only the Holy-Rus Model is, however, pre-discursive in terms of the SLL discursive formation. With the Civilized-World Model, the SLL discursive formation stepped into the universe of discourse. where it has

\footnotetext{
${ }^{20}$ Russians and non-Russians in Muscovy must have been taught literacy alike, as described regarding Russians in the period from the sixteenth to the eighteenth century in Pekarskij 1862. 1:167-186. The testimony of educated contemporaries such as the author, translator and publisher Fedor P. Polikarpov (circa 1670-1731) helps one get an idea how this was done. In the preface to the 1721 edition of Meletij Smotrickij's grammar of Church Slavonic, Fedor Polikarpov deplores the fact that the study of grammar in Russia is neglected. being traditionally replaced by memorizing the alphabet followed by reading from various religious books such as casoslov 'Book of Hours', psaltir' 'Psalter' and apostol 'Book of the Apostles'.
} 
remained ever since, evolving as outlined in chapters 3 and 4. The only Holy-Rus textbook I know of, NORJa 1839, takes its cue from the trends in secondlanguage learning introduced by the Civilized-World doxa.

The textbooks of the postmodern Global-Village Mosaic Model exist in a non-discursive mode of a different nature than its premodern counterparts. The main characteristic of the postmodern universe of discourse is the fragmentation of its discursive practice, its lesser articulation in comparison with the discourses of the modern period. which brings to the fore the immanent Bakhtinian polyphony of human interaction. ${ }^{27}$ In this universe, the second-language textbook author is robbed of his/her role as cultural mediator and transformed into a mouthpiece. It is through the mouthpiece that we hear a number of voices, each preserving its individuality. The message does not add up to a single image but to a haphazard mosaic, which is different every time around (as a comparison between RT 2000 and R 2000 will prove). If the premodem period did not favour discourse about Self in its culturally specific social habitat because there was nothing to say - everything was clear without speaking, the postmodem adversity to discourse seems to be an act of despair, resulting from the realization that no amount of speaking will produce a true explanatory model of the extremely complex social reality in which we live. All an author can hope for is to mirror an arbitrary fragment of this complex reality.

Not surprisingly, the buds of modernity and postmodernity can be identified a posteriori in textbooks that by the majority of their features belong to the previous period, the premodern and the modern one, respectively. In other words, transition from period to period is not sudden but gradual.

PZRJa 1868 provides a typical illustration of the Civilized-World Model. It consists not of texts created specifically for the purpose of the textbook but mostly of citations. Noticeable among these is the output of the generic speaker,

${ }^{27}$ For an analysis of M. M. Bakhtin's usage of the term polyphony. see Magomedova 1497. 
folklore genres such as thematically grouped proverbs (PZRJa 1868, 2, 3, 4, 1518), riddles (PZRJa 1868, 2, 4, 18-20), pobasenki 'stories' (PZRJa 1868, 20-23), anecdotes (PZRJa 1868, 23-29), tales (PZRJa 1868, 29-54) and rhymes such as the following:

(96) Otčego kot gladok? Poel da i nabok. (PZRJa 1868, 4)

'Why is the tomcat sleek? Having eaten, he drops on his side [to sleep].'

(97) Ne penjaj na soseda. kogda spiš’ do obeda (PZRJa 1868,4)

'Do not blame the neighbour if you sleep until noon.'

In congruity with its demonstrated interest in folklore as the expression of traditional values and the generic speaking subject behind it, PZRJa 1868 follows folklore practice in its lack of concern with authorship. It never indicates the names of the exemplary speakers who authored the quoted texts, including poems (PZRJa 1868, 55-66). Moreover, it gives priority to the generally valid over the subjective, the personal and the ephemeral. General truths regarding unique referents, as in (98), take turns with generic referents, as in (96) where kot can be this specific tomcat in front of us as well as a generic tomcat or in (97) where the addressee can be anybody.

(98) V Rossii dve stolicy: Sanktpeterburg i Moskva. Kiev stoit pri Dnepre, a Odessa pri Černom more. (PZRJa 1868, 10)

'There are two capital cities in Russia: St. Peterburg and Moscow. Kiev is on the Dnepr River and Odessa on the Black Sea coast.'

PZRJa 1868 adopts a didactic tone when it refers to education and ethics:

(99) Učen'e - svet, a neučen'e - t'ma. (PZRJa 1868, 15)

'Leaming is light and ignorance is darkness.'

(100) Vek živi, vek učis.' (PZRJa 1868, 15)

'Even if you live to be a century old. you should constantly study.' 
(101) Pravda gruba, da Bogu ljuba. (PZRJa 1868, 16)

'Truth is rough but God loves it.'

(102) Lư̌še bednost' da čestnost', neželi pribyl' da styd. (PZRJa 1868, 16)

'Poverty and honesty are preferable to profit and shame.'

(103) Prazdnost' est' mat' porokov. (PZRJa 1868, 17)

'Idleness is the mother of all vice.'

Good manners as the quintessential characteristic of the civilized person are of constant interest for authors subscribing to the Civilized-World Model. In the second pan of MG 1706, Elias Kopijewitz offers eight dialogues, the last of which focuses on table manners. Two characters, Ivan and Pavel, converse while laying the table. At one moment the following exchange takes place:

(104) I[van] Teperū uêisja obyčaevũ.

P[avel] Kakixũ obyčaebŭ [!] učitisja.

I[van] Kotoryxŭ pristolě deržatisja.

P[avel] Prošu tebja na uči menja.

I[van] Dobroxotno sie sotvorju. Zdèlaju.

P[avel] Ja priležno poslušaju.

I[van] Ne měšai mně teperŭ.

P[avel] Ne reku i slova. (MG 1706, 72-73)

Ivan: Now leam the customs.

Pavel: What customs should I learn?

Ivan: The customs one should obserie at the table.

Pavel: Please teach me.

Ivan: I will gladly. I will do it.

Pavel: I shall listen diligently.

Ivan: Do not stand in my way now.

Pavel: I won't say a word.'

An impressive series of thiny imperative sentences follows, which cover table manners in chronological order starting with "cut your fingernails first" and ending with "thank God" at the end of the meal. The rules are familiar. One is urged to sit straight, not to put one's elbows on the table, not to pick one's nose, to reach for the food that is closer and so on. The ritual flavour of the exchange is 
emphasized by the fact that the two characters take turns in reciting the rules. The directness with which these commands are issued reminds readers of the Proselytizing Model. In fact. strictly speaking, this is the Proselytizing Model of its day, with the significant difference that it functions in a doxic mode.

Preoccupation with good manners is overwhelming, as the following quotation shows:

(105) Včerašnij gost' naskučil mne svoimi glupymi rasskazami. Ja udivljaus', kak èto u vas xvatalo terpenija dva bityx casa slušat' takuju boltovnju? Ja mogu sebe ob"jasnit' èto tol'ko tem, čto vy, kak xozjain, ne mogli ego obižat'; v drugom slučae vy by poprosili ego zamoľ̌at'. Neredko prixoditsja postupat' protiv svoej voli. (NSRJa 1875, 93-94)

'Yesterday the guest bored me with his silly stories. I am surprised that you had the patience to listen for two whole hours to such twaddle. I can only explain this to myself with your duty as a host not to offend him; otherwise you would have asked him to shut up. Not infrequently one has to act against one's will.'

Štefan Marcella dedicates a whole chapter (Conversation 35) to rudeness and politeness (RRG 1827, 203-214). It is unfortunately too long to cite entirely. The characters marked as A and B discuss a certain Mr. Bodoil, whom they had met socially and who appalled them with his rude manners:

(106) proxožu molčaniem ego nevežestvo, skupost' i zlobu; no ja vo vsju žizn' moju ne vidal čeloveka. kotoryj by sebja tak xudo vel. Vxodja $v$ komnatu. on edva li komu klanjalsja. On dumo pričesan byl; i pritom totčas načal $v$ golove česat'. Prosili ego sest', i on sel, no vse česalsja. Po rukam ego vidno bylo, cto on celuju nedelju ne umyvalsja. Vstavaja so stula, on oprokinul ego s velikim šumom. On čut' ne napleval odnoj dame na plat'e. A kak G. Bodoil zabyl svoj platok, to zaigryval casto nosom samuju neprijatnuju muzyku, $i$ naipače vo vremja stola. (RRG 1827,203 )

'I shall pass in silence his ignorance, stinginess and spite; but I never in my life saw a person who would behave so poorly. On entering the room he hardly bowed to anybody. His hair was poorly brushed; and besides he started right away to scratch his head. He was asked to sit down and he sat but he continued to scratch. One could see on his hands that he hadn't washed for a week. When he stood up from his chair, he tipped it over very noisily. He almost spat on the dress of a lady. And since Mr. Bodoil had forgotten to 
fetch his handkerchief, he was playing with his nose the most disagreeable tunes, especially during dinner.'

Then A and B reflect on why some people are so poorly bred and come to the conclusion that it is a class thing: those of low birth frequently have no access to good upbringing but some of them due to chance and to their inborn intelligence succeed in overcoming the drawbacks of their social class. Alas, that is not the case with their new acquaintance:

(107) Za stolom on tak prjamo sidel kak mešok. Kak podnesli emu bljudo, to on vybral, vse čto emu po vkusu bylo; i pritom očen' medlenno. Čto kasaetsja do salfetki, to s načala uronil ee pod stol; a čtob obteret' guby, on upotrebljal pal'cy i temi že pal'cami bral casto mjaso s tarelki. Tol'ko ego golos slyšen byl za stolom: "ja ne xocu sego, ja ne ljublju ètogo"; no kogda on naxodil cto nibud' po svoemu vkusu, to ne el, a żral; ot togo on i obžeg sebe rot, evši sup, kotoroj emu očen' nravilsja. Pritom na skatert' oprokinul stakan medu, i drugoj razbil; a baryne, kotoraja po neščastiju sidela podle ego, popala vsja gorčica na plat'je. (RRG 1827,204 )

'At the table he was sitting as straight as a sack. When he was served a dish, he would choose from it everything that suited his taste and he would do that very slowly. As far as the napkin is concerned, he dropped it under the table at the beginning and he used his fingers to wipe his lips and with the same fingers often picked meat from his plate. One could hear only his voice at the table: "I don't want this, I don't like that". When, however, he found something corresponding to his taste, he would not eat but gorge. That is how he burnt his mouth eating the soup that he liked very much. At that he tumed a glass of mead over on the table and broke another one. All the mustard ended up on the dress of the lady who was unfortunate enough to sit beside him.'

Afterwards the interlocutors contrast this fellow with a certain Arist, who is his opposite. and conclude:

(108) Vy vidite iz ego primera, čto učtivost' sostavljaet istinnuju prijatnost' obšcestva; i čto ona vernejłaja doroga dlja priobretenija družby čestnyx ljudej. (RRG 1827, 214)

'You see from his example that politeness constitutes the true agreeableness of society and that it is the easiest way to acquire the friendship of honorable people.' 
More than a century divides MG 1706 from RRG 1827. What changed in that time is not the values they share or the desire to discuss them at length but the form in which they are enforced: by direct reference to rules in MG 1706 and by the indirect social sanction of gossip in RRG 1827. What a difference between this ardent promotion of good manners and the matter-of-factness of a Ionescostyle later passage:

(109) Kogda my xotim obedat, my sadimsja za stol. Pered obedom stol pokryvajut beloj skatert'ju. Pered každoj personoj stoit tarelka. My kladem kušan'e na tarelku. Tarelki krugly. Ėtot stol četyreugolen. Kušan’ja na stol podajut na bljudax. My berem ix s bljud i kladem na naši tarelki. My edim sup ložkoju, mjaso - vilkoju. My p'em vodu iz stakana, a kofe - iz caški. [...] Iz cego my p'em vino? P'ete li Vy ego iz butylki? Net, ja nalivaju vino iz butylki v stakan. (RU 1902, 49)

'When we want to dine we sit at the table. Before dinner the table is covered with a white tablecloth. In front of every person there is a plate. We put the food on the plate. The plates are round. This table is quadrangular. The food is brought to the table in dishes. We take it from the dishes and place it on our plates. We eat soup with a spoon and meat with a fork. We drink water from a glass and coffee from a cup. [...] What do we drink wine from? Do you drink it from the bottle? No. I pour wine from the bottle into a glass.'

The contrast between (109), on one hand, and (104) to (107), on the other. parallels that between the Proselytizing and the Broad Common-Ground Models.

If good manners were so fervently promoted in the Civilized-World Model, religion often was not. One can encounter both open defiance of Orthodox Christian rituals like fasting, as in (110), and customary reliance on God's protection, as in (111).

(110) Vot èta govjadina kažetsja očen' xoroša. Stanctel' ee kušat'? Ili vy postnicaete? Ja vsegda em skoromnoe. (RRG 1827, 103)

'Here, this beef looks very nice. Will you have some? Or are you keeping Lent? I always eat meat and dairy products.'

(I11) Bez Boga - ni do poroga, a s Bogom - xot’ za more. (PZRJa 1868 16)

'Without God do not dare to go to the threshold: with God you can go even overseas.' 
What deviations from the typical Civilized-World Model can be seen as precursors of the coming modem age? I shall look into three textbooks for such deviations. NERD 1822 consists of one hundred and thirty lessons dealing with matters of everyday importance presumed to be of equal interest to anybody anywhere. Topics include greetings, polite small talk, the weather, food, school, second-language leaming, city life, shopping, writing letters, baptism, marriage and funerals, female virtue and vice, travel, games and disease. The only overt distinction made between Russians and foreigners is the former's recognized excellence in second-language acquisition leading to a perfect blending in European high society. The remark is made for practical reasons in order to explain why parallel texts in a number of European languages are a desideratum in second-language textbooks:

(112) Rossijskoe Junošestvo oboego pola po spravedlivosti slavitsja znaniem inostrannyx jazykov: nekotorye razumejut cetyre jazyka, mnogie dva i tri; a znat' odin i ne dikovinka. Počemu lučše imet' odni razgovory, a ne raznye, na raznyx jazykax. (NERD 1822, i)

'Russian youth of both sexes are rightly notorious for their knowledge of foreign languages: some speak four languages. many two and three, whereas to know one language is no wonder at all. This is why it is better to have the same dialogues rather than different ones in different languages.'

One such young Russian gentleman is described in lessons 94 and 95 . He is a 25-year old single Russian, "an accomplished Gentleman" who "dresses very well", "dances neatly, fences and rides very well". He also "plays on the German flute, the violin, et several other instruments".

(113) Although he is a Russian, yet he speaks French, Italian, German et English so well, that among the French themselves they think him a Frenchman. He speaks Italian, as the Italians themselves; they take him for a German among the Germans: et he passes for an Englishman among the Englishmen. How can he be master of so many different languages? He has a happy memory, et has travelled a great deal. He has been two years at Paris, six months at Rome, a year et a half in Germany, et a year in England. He has seen all the Courts of Europe. (NERD 1822, 138-142) 
GTJa 1835 gives parallel texts in three languages: Russian, French and German. A large number of stereotypical small-talk phrases are supplemented with generic sentences like these:

(114) Ne dolžno vverjat' sebja: nedrugu, zloj ženščine i lošadi. (GTJa 1835, 180)

'One shouldn't entrust oneself to the enemy, to a wicked woman and to a horse.'

(115) Ljudi (sut') vsegda nedovol'ny tem. čto oni imejut. (GTJa 1835, 205)

'People are always dissatisfied with what they have.'

(116) Ctoby byt' xvastunom, nadobno imet' xorošuju pamjat'. (GTJa 1835, 207)

'In order to be a braggart. one has to have a good memory.'

(117) Nevožmožno imet' vse, čego želajut. (GTJa 1835, 217)

'It is impossible to have everything one wishes.'

(118) Ot utra do večera možet vse izmenit'sja. (GTJa 1835, 225)

'Everything may change between the morning and the evening.'

(119) Ulybat'sja ili usmexat'sja vo vremja, est' delo čelovečeskoe; no gromko xoxotat' i vo ves' rot smejat'sja - nikomu ne pristojno, a pače molodym ljudjam. (GTJa 1835, 373)

'It is human to smile or to grin when appropriate, but to laugh boisterously and to roar with laughter does not become anybody and least of all the young people.'

(120) Obuzdyvaj tvoj jazyk, a bolec potomu, čto nekogda nadležit otvečat' za každoe slovo, ne tokıno za oskorbitel'noe, no daže za glupoe $i$ bez rassuždenija vygovarennoe. (GTJa 1835, 374) 
'Tame your tongue, most of all because there will come a time when you will answer for every word, not only for that which is abusive but also for the silly ones and those recklessly pronounced.'

(121) Ver'te, chto bol'še ljudej pogibaet ot vina, neželi ot vody. (GTJa 1835, 377)

'Trust me, more people perish because of wine than because of water.'

(122) Vse narody, živuščie $v$ bednosti, sut' durny soboju ili bezobrazny. (GTJa $1835,407)$

'All nations living in poverty are either ugly or deformed.'

History is represented only in the form of anecdotes, as in (123), or in statements eulogizing the achievements of Russian monarchs seen against the background of their European peers, as in (124).

(123) Ekaterina II, Velikaja, Imperatrica Vserossijskaja, vo vremja putešestvija svoego $v$ poludennyja gubemii Rossijskoj imperii, pribyla $v$ gorod Poltavu, $i$ otpravilas' videt' to mesto, gde Petr Velikij pobedil Švedskago Korolja Karl XII. Po pribytii na mesto, naxodivšijsja togda v svite Gosudaryni, Francuzskij Poslannik skazal: "Vaše Velicestvo! na sem meste Velikij Petr spas Rossiju." - "Pravda, otvečala Gosudarynja - eželib togo togda ne slučilos', to i nas by teper' zdes' ne bylo." (GTJa 1835, 396-397)

'Catherine II the Great, the Empress of Russia, while travelling in the southem provinces of the Russian Empire, arrived in Poltava and went to visit the place where Peter the Great had defeated the King of Sweden, Charles XII. When they came to the spot, the French Ambassador who had joined at that time Her Majesty's suite said: "Your Majesty! In this place Peter the Great saved Russia." "It is true," the Empress answered. "Had it not been for that event, we wouldn't have been here today."'

(124) Aleksandr 1, Imperator Vserossijskij, terpeniem, velikodušiem. priveržennost'ju svoix poddannyx $i$ xrabrostiju vojsk, pobedil vraga nepobedimago, vozveličil Rossiju, i vosstanovil mir vo vsej Evrope. (GTJa $1835,405)$

'Alexander I, the Emperor of Russia, with his patience, generosity, the devotion of his subjects and the valour of his army defeated an invincible foe, exalted Russia and restored peace all over Europe.' 
The only Russian cultural peculiarity explicitly mentioned in the textbook is patronymics, stated to be a specifically Russian phenomenon nonexistent in German and French. Furthermore, patronymics are said to be restricted to the nobility (GTJa 1835, 82-83).

SRPJa 1838 is definitely premodem both in its attitude to secondlanguage teaching and its perception of Self as unproblematic. Without discussing it overtly, it offers a realistic representation of Russian class structure seen from above. Characters comprise representatives of the nobility, among them a physician, a general and a lady. The main male character of the dialogues (SRPJa 1838, 94-134) belongs to the nobility, sleeps until noon and has a servant to whom he uses ty 'you (sg.)' but who responds using vy 'you (pl.)' and helps him to get dressed: the same address forms are used between the nobleman and his tailor (portnoj), whereas between him and his friend there is a mutual vy. In other words, the asymmetric $v y / t y$ realistically marks social distance, while the symmetric vy marks negative politeness, as defined by Brown \& Levinson (1987, 70, 245-246). Included is one conversation between an Orthodox Christian and a Catholic about religion and the rites of various confessions. Predictably, religious differences are perceived as more salient in comparison with other cultural differences. They must have been felt as even more relevant in Catholic Warsaw where the textbook was published, at the time part of the Orthodox Russian empire.

As it turns out, several dialogues in SRPJa 1838 follow closely those in RG 1750, 230-280. K. A. Tokarev, the author of SRPJa 1838, was the bilingual holder of an obviously Russian name, whereas the royal translator Michacl Groening, the author of RG 1750, was a Swede from Finland (Unbegaun 1969, xii). If one expects to find any divergences due to their different vantage points. one will remain disappointed.

To summarize, in NERD 1822. GTJa 1835 and SRPJa 1838 one can glcan an occasional cultural characteristic of Russian society: its Orthodox Christianity, 
the ability of its noble youth to blend in with European high society, the Russian system of naming. Two of these (patronymics and Orthodox Christianity) were to become in the modem period staple cultural content in second-language textbooks. Here, however, they are isolated and their presence is accidental against the neutralization of the insider and outsider perspective, which is the hallmark of the Civilized-World Model. The third characteristic highlights the European identity of Russians, which at this stage and among second-language textbook authors subscribing to the Civilized-World Model is undisputed. If there is a difference between Russians and West Europeans, it is the former's universality, their ability to be at home anywhere in Western Europe.

There also are early signs of the split of textbook authors into insiders and outsiders, which was to come later. James Heard, who claims that his is the first Russian grammar for English speakers (PGRL 1827, iii), situates his reference grammar against the background of classical Greco-Roman culture. He is keen to mention whenever possible the contacts of his countrymen with Russians, but cannot find more than the following three occasions to mention: Karamzin's delight over the beauties of England (PGRL 1827, 8-9): Chancellor's expedition to the shores of the White Sea, which established the first commercial intercourse with Russia (PGRL 1827, 40); and the experiences of the eighteenth-century 'friend of the suffering' Howard in Sympheropol after Mouravieff (PGRL 1827. 241). There are only three readings, which to some extent introduce Russian reality: a description of an evening on the Moscow river after Joukofsky (PGRL 1827, 95-100), a description of Russia's geography and climate in most general terms (PGRL 1827, 115-116) and "Our native country" after Shishkoff (PGRL 1827, 137-139). Noticeable is the absence of Puskin, who was at this time the recognized star in Russian high culture (Reitblat 2001, 51-69). Heard's own observations on Russian language, society and culture are limited to the obvious, as this complete list demonstrates. Most of them are hosted in miscellaneous sentences for translation: 
(125) Petersburg is one of the finest towns in Europe; in this City there are many magnificent houses. (PGRL 1827, 17-18)

(126) Among the Russian poets, Krillof, Dmitrieff and Chemnitzer are celebrated for their fables. (PGRL 1827, 32-33)

(127) The south of Russia produces in great abundance barley, buckwheat, oats and every kind of grain. (PGRL 1827, 39)

(128) Rurick was the founder of the Russian Empire. (PGRL 1827, 40)

(129) Russian peasants wear sandals, made of the bark of the birch, instead of shoes. (PGRL 1827, 41)

(130) Much iron is exported from Russia. (PGRL 1827, 44)

(131) The greater part of the inhabitants of Russia belong to the Slavonian race [plemia]. (PGRL 1827, 51)

(132) Patronymicks [sic] are "the usual manner of addressing persons of all classes". (PGRL 1827, 64)

(133) The French language is easier than the Russian; but the Russian is richer than the French. (PGRL 1827, 83)

(134) Russia is the most extensive Empire in the world. (PGRL 1827, 85)

(135) On the monument of Peter the Great there is the following inscription: Catherine the second to Peter the first. (PGRL 1827, 113)

(136) Peter the Great defeated Charles the twelfth at Poltava in the year one thousand seven hundred and nine. (PGRL 1827, 114)

(137) Roubles and copecks are coins used in Russia. (PGRL 1827, 147)

(138) In Kamtchatka dogs are harnessed instead of horses. (PGRL 1827, 193) 
(139) The Neva flows out of the Ladoga lake. (PGRL 1827, 205)

(140) Many Nomadian tribes inhabit (live in) Siberia, (PGRL 1827, 230)

(141) Peter the Great established the first Russian fleet. (PGRL 1827, 231)

(142) Of the rivers, which fall into the Caspian Sea, the Volga is the most considerable. (PGRL 1827, 249)

(143) The Ural Mountains divide Siberia from European Russia. (PGRL 1827, 266)

This textbook shows the humble beginnings of the Cross-Cultural Comparative Model in the bosom of the Civilized-World Model. The former model's further development is marked by orientation from superficial to indepth knowledge of the target culture and a move to centre stage of the concern with cultural divergences.

The transition from modemity to postmodemity is no less gradual. The Russian second-language textbooks split into a majority and a minority if classified according to their adherence to one of the two possible principles of discourse organization. The majority espouses the monologue; a minority, the dialogue. The dialogic discourse organization contains the seeds of postmodemity. Monologic treatment of the speaking subject predominates in the Proselytizing, the Common-Ground and the Cooped-Up Insider Models in all their variations and period embodiments. Dialogic treatment may be characteristic of the Cross-Cultural Comparative Model, as illustrated by REB 1938. In the last decades of the twentieth century, elements of dialogue start to penetrate the Broad Common-Ground Model and lend it a new flavour. A typical example is RST 1985, an instance of the Gorbačev-era Communist discourse: that is, the Communist discourse with a human face, in its Broad CommonGround modification. RB 1999. reflecting the post-Soviet Reconciliatory 
discourse in which Communist, pre-Communist and post-Communist heritage peacefully coexist, has as precursors Soviet-time reconciliatory textbooks like RKG 1931, NRG 1935 and CR 1948, written by émigré authors. Even more important is the dialogic treatment of identity in textbooks like V 2 1991, P 2 1996 and MPMR 1998, representatives of the pluralist variety of the post-Soviet Broad Common-Ground Model.

I shall base my discussion of the peculiarities of the monologic and the dialogic treatment of identity on the Russian gender definitions and relations. The speaking subject of Russian (if specific rather than generic) is necessarily linguistically gendered most of the time. In the past tense all three grammatical persons are compulsory gendered in the singular; in the present and the future tense, however, gender is always explicitly marked on the third person, whereas in the first and the second person gender marking is restricted to nominal predicates. The treatment of gender in the SLL discursive formation forms a continuum with the purely linguistic approach at one end and the concomitance of linguistic and cultural statements at the other. Most textbooks cannot avoid providing some kind of cultural information on gender.

RHG 1635-1648 devotes its first thirty-five pages to a conversation at the table between Petr, his wife Marja, their two teenage sons Anca and Franca, and their guests. Maria orders her two sons around and they comply without a sound. Among the adults, there appears to be equality between men and women both in terms of social status and in terms of their input to the conversation. At one point Petr refuses to serve meat to his wife and son with the following words:

(144) Rěži sama, polno tobě rostu. Pomogi sama sobč, jaz tobè ne xoěju služiti. Jaz nikomu ne služu opročě sobja. (RHG $1635-1648,24-25$ )

'Cut it yourself, you are tall (old?) enough. Do it yourself. I don't want to serve you. I serve nobody but myself.'

After a while, however, when Marja says that the dish is too far away and she cannot reach it. he serves her and so does Rixart, one of the guests (RHG $1635-1648,34-35$ ). This is the first glimpse that readers of Russian second- 
language textbooks get of men and women in interaction. As a translation from a Dutch source, this textbook, however, does not provide a reliable image of gender relations in Russia (Keipert 1993, 287). At a later date, Russian women are presented as comrades-in-arms to men ( $R X 1872,161$; RJaSI 1970, 352) or as mothers (RX 1894, 49, 111; RM 1901, 74; RR I 1914, 20; URJa 1973, 2:88; RB 1999, 364-367). They are the pivot on which the Russian world rests, as N. A. Nekrasov has it in the poem Moroz - krasnyj nos (1864): konja na skaku ostanovit / v gorjaščuju izbu vojdet '[the Russian woman] can stop a galloping horse, [she will not hesitate to] enter a buming hut' (cited in RMLR 1947, 231, among others). Generally, the description of gender relations does not leave the public sphere. Here is a typical polite exchange from the end of the Imperial period:

(145) Anna Vasil'evna (žena): Ja očen' rada znat' Vas lično, posle togo, kak muž moj mne tak mnogo o Vas govoril. - Kolja: Xorošee ili xudoe govoril on obo mne? - Anna Vasil'evna: Počemu Vy dumaete, čto pro Vas govorili xudoe, ved' Vy znaete, čto moj muž ne sposoben govorit' xudoe o svoix dnuz'jax. - Kolja: V ètom ja soveršenno uveren, ja znaju, čto Saša olicetvorenie dobroty $\mathrm{i}$ menja raduet, čto on izbral sebe takuju miluju suprugu, kotoraja ne pozvoljaet ego obižat'. - Anna Vasil'evna: Blagodarju za kompliment. (RU 1902, 125)

'Anna Vasil'evna (wife): "I am delighted to meet you in person after everything I have heard about you from my husband." Kolja: "What did he say about me, good or bad?" Anna Vasil'evna: "Why do you think you were badmouthed? You know too well that my husband is not capable of saying anything bad about his friends." Kolja: "I am absolutely convinced of it. I know that Sasa is the embodiment of kindness and I am glad that he chose such a lovely spouse who does not let anybody insult him." Anna Vasil'evna: "Thank you for the compliment."

Not unlike Imperial Russians, post-Soviet speakers also favour arch double talk. A bunch of students of Russian have just visited a Russian family, where they were treated with delicious Russian pies by the beautiful Svetlana. Everybody noticed that Viktor was attracted to Svetlana. We should not be misled by the fact that the following exchange is presented to us as happening among foreigners. What they say has a true Russian ring to it: 
(146) Viktor: Ne mogu zabyt' russkie pirogi. Alan, tebe nužno vzjat' recept. Alan: Ty prav. Kak ty dumaeš', možno pozvonit' Svete?

Viktor: Svete? Začem? Ona dala recept Sjuzanne. Vproð̌em, ja s udovol'stviem mogu peredat' tvoju pros'bu Svetlane.

Anna: Ty? A, ponimaju, Svetlana krasivaja devuška, i tebe s nej prijatno razgovarivat'.

Sjuzanna: Emu interesno razgovarivat' so Svetlanoj. I potom... Svetlana pomogaet Viktoru izučat' russskij jazyk.

Marta: Ona ob"jasnjaet tebe grammatiku?

Filipp: Bednyj Viktor! Razrešite i mne skazat'! Predlagaju vam druguju temu.

Vera Sergeevna: Da zdravstvuet mužskaja solidarnost'! Soglasna s vami. (TNM 1994, 70)

'Victor: I cannot forget the Russian pies. Alan, you must get the recipe.

Alan: You are right. What do you think, could we phone Sveta?

Victor: Sveta? What for? She already gave the recipe to Susan. Nevertheless, I'll be glad to pass your request to Sveta.

Anna: You? Oh, I see. Svetlana is a beautiful young woman and you like talking to her.

Susan: He enjoys talking with Svetlana. And besides... Svetlana helps Victor with his Russian.

Marta: Does she explain grammar to you?

Phillip: Poor Victor. I want the floor. I would like to change the topic of conversation.

Vera Sergeevna: Long live male solidarity! I agree with you.'

Women in the Soviet public sphere are presented as follows:

(147) Zhenščina i mužčina polučajut v SSSR odinakovoe vospitanie. Mal'čiki i devočki vmeste igrajut na detploščadke. Oni vmeste proxodjat odin i tot že kurs politexničeskoj క̌koly, u nix odna obšcaja detskaja organizacija organizacija junyx pionerov. Uže $v$ škole pionery, mal'čiki i devočki, izučajut proizvodstvo i prinimajut učastie $v$ obščestvennoj żizni. Molodye devuški i junoši vstupajut v komsomol - Kommunističeskij sojuz molodeži. Komsomol - učenik i posledovatel' leninskoj partii bol'ševikov. On vedet bol'šuju rabotu po vospitaniju molodeži: on aktivno učastvuet $v$ rabote sovetov, $v$ rabote predprijatij $\mathrm{i}$ učreždenij, $v$ professional'nyx $i$ drugix obščestvennyx organizacijax, a takže v žizni armii i tlota. (RESW 1933, 104-105)

'Woman and man in the USSR get the same upbringing. Boys and girls play together in the open air. They graduate from the same polytechnic high school, they participate in the same children's organization - the young pioneer organization. While still in school, boys and girls study technology and participate actively in the life of the community. As young adults they 
become members of the Young Communist League. The Young Communist League is the pupil and follower of Lenin's Bolshevik Party. It carries out a huge amount of work towards the education of youth. It takes an active part in the work of Soviets, enterprises and institutions, in the professional and other organizations, as well as in the life of the army and the navy.'

(148) V SSSR ženščiny imejut takie že prava, kak i mužčiny. Sovetskie ljudi uvažajut trud ženščin. Sredi ženščin v SSSR est' učenye, inženery, arxitektory, mnogo vračej, učitel'nic, agronomov. Sovetskij narod doverjaet ženščinam vysokie posty. Naselenie vybiraet ženščin $\mathbf{v}$ organy upravlenija. Sovetskie ženščiny, vmeste s ženక̌činami drugix stran, učastvujut $v$ bor'be za mir, v bor'be za žizn' i sčast'e detej. Oni verjat, čto mir pobedit vojnu. Est' prekrasnye knigi o ženščinax $v$ naši dni, ob ix dostiženijax $v$ trude, nauke $i$ iskusstve. Dostiženija èti očen' bol'šie. (LR 1960, 136)

'Women in the USSR have the same rights as men. The Soviet people respect women's labour. Among Soviet women there are scientists, engineers, architects and many physicians, teachers and agronomists. The Soviet nation entrusts high-ranking positions to women. The population elects women to the government bodies. Soviet women together with women from other countries participate in the struggle for peace, life and happiness for children. They trust that peace will overcome war. There are wonderful books about women today, about their achievements in work, science and ant. These achievements are great.'

In conformity with Russian traditions, overt expression of sexism is rare. I have only one textbook in my collection that is guilty of this sin, as the following typical sentences for translation into English conclusively prove:

(149) Ona vsegda plačet kogda ona nezdorova; vse ženščiny ljubjat plakat'; oni vsegda plačut. (PRG 1938, 121)

'She always cries when she is ill. All women love to cry. They always cry.'

(150) Prošlo to vremja, kogda ženščiny sideli doma. ničego ne delali i daže ne mogli vyxodit' iz doma bez mužčiny; drugie vremena, drugie privyčki; celovek ko vsemu privykaet. (PRG 1938, 159)

'The time when women were sitting at home not doing anything, not even being allowed to go out unaccompanied by men, has passed by. Now times are different and the usages are different. One can get accustomed to anything.' 
(151) U ètoj staruxi sliškom mnogo volos na podborodke; u nee boroda; ona dolžna byla ly pojti k parikmaxeru pobrit'sja. (PRG 1938, 168)

'This old woman has too many hairs on her chin. She has a beard. She should have gone to the barber to get shaved.'

(152) Kto iz vas umnee, ona ili vy? - Konečno, ja umnee ee, potomu čto ja mužčina. (PRG 1938, 174)

'Who is smarter: you or she? - Of course, I am smarter, because I am a man.'

These sentences are so much out of character that I find it hard to believe that a textbook of a similar orientation could have been printed in Russia. If gender relations outside the public sphere catch the attention of textbook authors, which does not happen very often, they are usually presented in a romantic light as in the adaptations of K. G. Paustovskij's Sneg 'Snow' (URJa 1969, 1:110-115) or A. S. Puškin's Metel' 'Blizzard' (RREG 1992, 17-19).

Against this brief overview of the monologic treatment of gender in its variation, the dialogic nature of V 21991 stands out. The textbook presents four basic models of marriage: traditional, romantic. children-oriented and marriage between equal partners (V 2 1991, 122-127). This serious discussion is accompanied by a series of irreverent stories on less-than-ideal encounters between men and women. They feature the ardent wish of a secretary for the attentions of her boss (V 2 1991, 44). Zoščenko's narrative about the complex relations between three adulterous couples ( $V 21991,150-156)$ and power and prestige in gender relations (V 2 1991, 170-174). Besides, the textbook finds a moment for the image of courtly love that leaves women to make the final decision as expected throughout the past two centuries in Russia. The long fight Stas has waged for Katja's favours ends in the absence of his rival Igor' thus:

(153) Stas: Slušaj, ja sil'nee, i bystree, i točnee, cem on. I gorazdo umnee! Katja: Konečno, ty samyj bystryj, samyj sil'nyj. samyj umnyj, no vse-taki ja pojdu v kino s Igorem. (V 2 1991, 102)

'Stas: Listen, I am stronger and faster and more precise than him. And I am much smarter! 
Katja: Of course, you are the fastest, the strongest, the smartest, but I will still go to the movies with Igor'.'

This distribution of power between the sexes is very typical of Russia and is demonstrated over and over again in my collection of textbooks. This is the constant theme, against which we should evaluate all deviations. ${ }^{28}$ I shall limit myself to one more example. Two male friends are planning to visit the girlfriend of one of them, Daša, who wants to cut her beautiful long hair off and celebrate the event:

(154) - Kakaja že ona glupaja - postrič' takie šikarnye volosy. Poð̌emu ty ee ne otgovoril?

- Bespolezno. Ja uže davno ponjal, esli ženščina čto-to xočet, to mužčine ne stoit vozražat'. Ona vse ravno sdelaet po-svoemu.

- Moj drug, ty mudr ne po godam. (NIR 2000, 118)

"'How silly she is - to cul such splendid hair. Why didn't you dissuade her?" "It's useless. I have understood long ago that if a woman wants something, a man should not try to object. She will do it her way anyway." "My friend, you are amazingly wise for your age."'

The dialogic MPMR 1998 provides the following mix: the typical day of an average Russian family (31-32); wedding rites today (32-34), traditionally (39-41) and according to A. P. Cexov (37); and what men value in their wives according to L. N. Tolstoj (36), I. Grekova (38) and contemporary statistics (4142).

Such dialogic treatment of gender relations is only one pace removed from the Global-Village Mosaic Model. In the two textbooks that adhere to the Global-Village Mosaic Model, we encounter a total of five readings on gender: about flowers as the symbol of love and how affordable they are for men of various nationalitics (RT 2000, 32); about the mercantile motivations behind the

\footnotetext{
38 Working-class women in nineteenth-century England and France were found to occupy a similar position in society. Especially reminiscent of the Russian situation (see [278] and [279] as well as Illustration 67) are the traditional managerial responsibilities of wives. who were the ones to decide how to spend the money earned by husbands. whereas husbands were receiving back from their wives only a small allowance for their daily expenses (McKay. Hill \& Buckler 1995, 816).
} 
choice of spouse (RT 2000, 38); about the views of Russian feminist Masa Arbatova (RT 2000, 43); about the kinds of households favoured by students (RT $2000,76-77)$; and a young people's opinion survey on marriage ( $R$ 2000, 83). What textbooks of the Pluralist Broad Common-Ground Model and the GlobalVillage Mosaic Model have in common is that they express more than one point of view on their pages. The difference between them lies in the essence of what gets presented. The Pluralist Broad Common-Ground Model chooses what is symbolically important to Russians and does not shy away from repetition. It tells the world what "everybody" in Russia knows. The Global-Village Mosaic Model strives for originality and considers something worth mentioning only if it is news; in other words, it adopts the perspective of the mass media. Chances are that what is new to Russians and therefore interesting to hear will be new to the textbook audience as well. From the vantage point of the addressee, the GlobalVillage Mosaic, the Holy-Rus. the Civilized-World and the Proselytizing Models of all designs oppose the other textbook models in not treating differentially the four groups into which audiences can be divided (Table 1). Furthermore, the Global-Village Mosaic Model can be considered to be a kind of a Broad Common-Ground Model, which, however, defines common ground in an essentially new way.

In regard to illustrations, I can say little because I have to base my observations on one textbook only ( $R$ 2000). It features descriptive illustrations of two kinds: cartoons by A. N. Novikova and photos. The relationship of both types of illustrations to the stories they accompany is similar. They are serious or ironic visual interpretations of a motive or event presented in the narrative.

To summarize, even if a certain area of social life turns out to be outside the universe of discourse at a given time, as it happened to second-language leaming or national identity, this does not mean that society as a whole is outside it. Commentary and discursive formation should therefore be treated as human 
universals. From a discursive perspective, the non-discursive textbook models are seen to be not distinct phenomena but manifestations of the models attested in the universe of discourse. The six discursively relevant models are Proselytizing, ${ }^{29}$ Broad Common-Ground, ${ }^{30}$ Narrow Common-Ground, CoopedUp Insider, Cross-Cultural Comparative and Ethnocentric Outsider Models. Moreover, the second-language textbook models can be reduced to two (with several subvarieties) according to the extent of authority authors claim over the speaking subject. They can either insist that the image they produce is complete or recognize that it covers only part of the ground. A classification of textbook models by alleged completeness would group the Proselytizing and the Ethnocentric Outsider Models together as "total" representations of the speaking subject and oppose them to the partial representations provided by the Broad Common-Ground, the Narrow Common-Ground, the Cooped-Up Insider, and the Cross-Cultural Comparative Models.

Table 3 surveys the Russian perception of Self in the discursive and nondiscursive mode by historical period.

\footnotetext{
29 Including period embondiments such as the Holy-Rus. the Civilized-World, the Autocratic, the Cummunist. the Dissident and the Bridging Models.

30 Including the Autocratic. the Soviet Reconciliatory, the Communist. the Bridging. the PostSoviet Recunciliatory, the Post-Soviet Pluralist and the Global-Village Mosaic varieties: for more details see chapter 6 .
} 


\begin{tabular}{|c|c|c|c|c|c|c|}
\hline Historical Period & \multicolumn{4}{|c|}{ Range of Represented Views } & \multicolumn{2}{|c|}{ Type of Discourse } \\
\hline Muscovite & & & & Joly Pus & \multirow{2}{*}{\multicolumn{2}{|c|}{ Non-discursive }} \\
\hline Early Imperial & & \multicolumn{2}{|c|}{ Civilizad World } & & & \\
\hline \multirow{2}{*}{ Late Imperial } & & & \multicolumn{2}{|c|}{ Autocratic } & Orthodox & סִ \\
\hline & Revolutionary & Westernizer & \multicolumn{2}{|c|}{ Slavophile } & Heterodux & 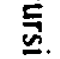 \\
\hline \multirow{2}{*}{ Soviet } & Communist & & & & Orthodox & \\
\hline & & \multicolumn{3}{|l|}{ Dissident } & Heterodux & \\
\hline \multirow{3}{*}{ Post-Perestrojka } & & Bridging & & & Orthodox & \\
\hline & Communist & & \multicolumn{2}{|c|}{ Patriotic } & Heterodox & \\
\hline & & $\begin{array}{l}\text { Glolial } \\
\text { Village }\end{array}$ & & & I inn-discursive & \\
\hline
\end{tabular}

Table 3. Identity in the Universe of Discourse 


\section{In the Field of Concomitance: Valuable Wholes and Their Symbolic Components}

Identity discourses provide answers to questions like the following: Who are we, ..............? What are we known for? What are we like? What makes me proud to be ...............? The dotted line stands for the appropriate label, which may be 'Russian', 'Orthodox Christian', 'Proletarian' and so on. In other words, the grid of specification may be citizenship, ethnicity, language, religion, class, gender and so on. The hierarchy of identities and their compatibility in regard to a single holder present special interest and are the cause of much diversity worldwide. The salience of a particular identity is situational. Because of their more direct connection to language, we have seen throughout this study more of ethnicity and citizenship than of class, religion and gender.

The answers to the identity questions are based on the events in which a group of people participated over time in a specific territory. The values attributed to these four variables (events, people, time and territory) will vary for different discourses even when they are rooted in the same set of reality. This happens because of the contrast between discrete and teleological discourse, on one hand, and the incessant and unstructured flow of human life, on the other. As Ladislav Holy says: "From the multiplicity of past events only those which are seen as significant are recorded (and hence remembered), and this significance is determined by their being perceived as having some consequence for the present: we are what we are because this or that happened in our past" (Holy 1996, 117). The sum total of events, people, time and territory is necessarily positively evaluated by the holders of the identity based on that sum total. The units in the four categories - events, people, moments in time, locations in the territory - are what Michel Foucault calls concepts (Foucault 1972a, 34). Concepts inside a 
discourse are linked in syntagmatic chains. A paradigm is the set of concepts that occupy analogical positions in competing discourses. Specific concepts will be called symbols if they acquire greater significance than others in the framework of a given discourse. In other words, symbols provide a bottom-line reading of the sum total. The most outstanding of those symbols correspond to Sherry Orner's summarizing symbols, as they are so powerful that they can evoke the whole of which they are part. In her own words: a summarizing symbol expresses and represents "for the participants in an emotionally powerful and relatively undifferentiated way, what the system means to them" (Ortner 1973, 1339). Symbols are never unequivocal: the same symbols can be used as bricks of diametrically opposed discourses. What one does with other people's symbols would depend on the compatibility of the discourses of which they are part. One can usurp symbols from compatible discourses and adapt them to one's own need. If the respective discourses are incompatible, one can only trash and ignore their symbols. An insight how this was done in the early Soviet period was provided in the fragment of The Golden Calf discussed in chapter 5.

The desire to perpetuate the memory of certain events or persons of symbolic value for the discourse manifests tangibly in the erection of monuments: note the Russian word for monument pamjatnik lit. 'memorial' from pamjat' 'memory'. The struggle between discourses has as one visible marker the destruction of monuments that glorify the wrong symbols, a phenomenon well documented throughout Russian history. Textbooks spend a lot of time presenting monuments in narrative and image (for instance, the renowned monument to Peter I built in St. Petersburg by Catherine II: PGRL 1827, 113; PRIRJa 1878, 100: V 2 1991, 113: RJaV 1995, 343-348) and describing events that take place in their vicinity (such as the annual poetic gatherings at Puškin's monument in Moscow, RST 1985, 256-257). Monuments bridge the temporal and the spatial dimensions of identity discourses. 
It is time now to explore how Russian identity discourses manifest in the SLL discursive formation in its evolution over time. The expectation is, as I argued in chapter 5 , that identity discourses would be best represented in textbooks of the Proselytizing and the Broad Common-Ground Models. We shall look into the valuable sum totals of concepts and their summarizing symbols as well as the paradigms of symbols that coordinate discourses inside the Identity discursive formation as we find them nested in the SLL discursive formation.

My collection of textbooks provides information about three separate sum totals of concepts. which may occur in distinct discourses but can also serve as a source for synthetic discourses. The synthetic discourses form their own sum totals of concepts by combining elements of various origins. We shall look first at the sum totals of the Holy-Rus and the Civilized-World doxas and the Communist discourse in their "pure" form and then at the synthetic discourses attested in second-language textbooks starting with the most influential ones the Autocratic and the Bridging discourses - and move from there to the Soviet and post-Soviet Reconciliatory discourses.

The earliest sum total is Christian and it characterizes in a pure form the Holy-Rus doxa, which elevates religion to the status of an overarching identity. Its territory coincides with the Orthodox Christian world. ${ }^{31}$ Christians are the relevant people and the time over which relevant events take place began with Jesus Christ but some of his precursors are also included in the story. The Christian sum total is featured in NORJa 1839. a textbook that underwent at least five editions. Its author, Vasilij Rklickij, provides readings on topics like Nekotoryja pravila iz Xristianskago učenija 'Some rules of the Christian doctrine' (NORJa 1839, 31-39), O Potope 'About the Deluge', O Voskresenii Iisusa Xrista 'About Jesus Christ's Resurrection', O Voznesenii Iisusa Xrista 'About Jesus Christ's Ascension', O sošestvii Svjatago Duxa na Apostolov. 'About the Holy Spirit's Descent on the Apostles' (NORJa 1839, 55-69), or 
among anonymous poems (NORJa 1839, 166-191): Molitva $k$ Angelu Xranitelju 'Prayer to the Guardian Angel' and $V$ den' svetlago Voskresenija Xristova 'On the Day of Jesus Christ's Luminous Resurrection'.

The second sum total of concepts is that of the Civilized-World doxa. Its stage is the world of Western civilization, which considers itself the descendant of classical antiquity. A typical example is offered by RG 1750, especially poignant if we take into account its reading selection of forty-six anecdotes (RG 1750, 281-296). Its geography includes Italy (with Rome, Naples, Florence. Mediolan and Venice), France (with Paris, Charanton, Saumour and Nancy), Germany (with Metz. Cologne, Nuremberg and the River Rhine), Great Britain, Spain. Austro-Hungary, the Ottoman Empire (with Constantinople and Alexandria), Persia and India. Chronologically it embraces the period from classical antiquity (represented by Philippe of Macedonia, Alexander the Great and Julius Caesar) on. The relevant group consists of the powerful and famous: monarchs (Bayezit. Charles V, Constantine the Great, François 1. Henri the Great, Henry VIII, Louis XIV, Tamerlane. William III), nobility, illustrious generals (George Kastrioti Skanderbeg. Duc de Créqui), popes, bishops and cardinals, thinkers (Thomas More and Sopater) and painters (Albrecht Dürer). Notable is the absence of Russia from this textbook's map, an omission corrected in later textbooks such as GTJa 1835. Two of its references to historical figures (cited above in [123] and [124]) give a fair idea of the kind of events and people that are part of this discourse.

The third and last distinct sum total of concepts is that associaled with the Communist discourse. According to my data, the Russian second-language textbooks came into contact with it around the time when its territory was shrinking to the size of the USSR. An idea about the initial global coverage of Cummunist discourse can only be obtained from reading RESW 1933 and to a lesser extent LRSDA 1933. Otherwise, traces of its previous, much broader scope

\footnotetext{
${ }^{31}$ For a glimpse at the changung definusun of Rus' in the pre-Muscovite period see Novickova
} 
are only found in the fact that until 1943 L'Internationale continued to be the anthem of the USSR and in the Soviet state emblem that features the globe. Both state symbols are frequently evoked in textbooks. For instance, textbook readers are told that the workers at the site of the Dneprogès power station in 1927-1932 sang $L$ 'Intemationale to mark their victory over nature:

(155) Na Dneprostroe 29 janvarja sostojalsja miting pobeditelej. Verojatno on imel mnogo obščego s tem, kotoryj ustroili krasnoarmejcy, kogda vzjali Perekop. Ljudi govorili nad Dneprom gordye slova, pominali imja Il'iča, pjatiletnij plan industrializacii, govorili o sorevnovanii, ob udarnikax, o budušcem sovxoze, kotoryj vozniknet $v$ zasušlivyx stepjax Pridneprov'ja... Sil'nyj veter naduval parusami znamena $i$ duxovoj orkestr gremel Internacional! A u tex stroitelej, cto neposredstvenno rabotali nad sooruženiem peremyčki, serdce bilos' vostorgom ot soznanija oderžannoj pobedy. (RKG 1931, 233-234)

'On October 29, at the Dneprogès site there was a rally of the winners. It was probably very similar to the rally organized by the Red Army men, when they seized Perekop. People were uttering over the Dnepr River proud words, they were mentioning [Vladimir] Il'ic [Lenin]'s name, the five-year plan of industrialization, they were talking about competition, shock-workers, the future state farm that will appear in the arid steppes by the Dnepr River... The strong wind was blowing the flags like sails and the brass band was playing L'Intemationale! And the hearts of those workers who were building the cofferdam itself were swelling with enthusiasm at the thought of the victory they had scored.'

While touring the Exhibition of the Achievements of Soviet Economy $V D N X$, a group of foreign students hear from their guide the following story, which is accompanied with a picture of the Soviet emblem:

(156) Šel 1918 god. V Sovetskoj strane vstrečali prazdnik Oktjabrja. God nazad rabočic i krest ‘jane Rossii provozglasili Sovetskuju vlast'. Teper’ nužno bylo sozdat' gosudarstvennyj gerb strany. Odnaždy Vladimir Il'ič Lenin rabotal v svoem kabinete. Tam że byli Ja. M. Sverdlov i F. E. Dzeržinskij. V èto vrcmja $v$ kabinet Lenina prinesli risunok gerba.

- Cto èto, gerb? Interesno posmotret'! - skazal V. I. Lenin, - i vzjal risunok. Gerb byl krasivyj: v centre zemnoj Sar, solnce, serp i molot, vokrug snopy pšenicy, a poseredine meč.

1094.59. 
- Interesno! - skazal V. I. Lenin. Ideja xorošaja, no začem meč? My boremsja, my dolžny osvobodit' svoju rodinu, no meč - èto ne naša emblema. On vzjal karandaš i začerknul meč.

7 nojabrja 1918 goda $v$ Moskve vstrečali prazdnik Oktjabrja. Utrom byla demonstracija. Na ulicax, na ploščadjax, na flagax - vsjudu ljudi uvideli gosudarstvennyj gerb strany - èmblemu mira i truda. (URJa 1969, 1:189)

'It was 1918. The Soviet people were preparing to celebrate the October Revolution. A year earlier the Russian workers and peasants had proilaimed Soviet rule. It was necessary now to create an emblem for the country. Once Vladimir Il'ič Lenin was working in his office. Ja. M. Sverdlov and F. É. Dzeržinskij were with him. At that time the drawing of the emblem was brought into Lenin's of fice.

"What is this? The emblem? Let us have a look!" V. I. Lenin said and took the drawing. The emblem was beautiful: in the centre the globe, the sun, sickle and hammer, surrounded by sheaves of wheat and in the middle a sword.

"Interesting!" V. I. Lenin said. "Good idea but what is this sword for? Indeed, we are fighting, we must liberate our homeland, but a sword - that is not our emblem." He took a pencil and cancelled the sword. On November 7, 1918 in Moscow people were celebrating the October Revolution. In the moming there was a rally. Pcople saw everywhere - in the streets, on the squares and on the flags - the state emblem, symbol of peace and labour.'

While the relevant group continued to be the toiling people worldwide, it was necessary to provide for them proper Russian second-language textbooks. The outcomes of this effort were RESW 1933 and LRSDA 1933. Once again. this time from the perspective of a particular identity discourse, we see that the scope of the group with which Self identifies has direct implications for secondlanguage leaming:

(157) Ty živěs’ v SSSR i rabotacš na zavode. Na zavode, gde ty rabotacš', est' i drugie inostrannye rabočie, angličane $i$ amerikancy. Vy vse xorošo znaetc tol'ko anglisjkij jazyk i ešče ploxo govorite po-russki. Ėto zatrudnjaet vaše aktivnoe učastie v obščestvennoj žizni. Drugie rabočie na zavode govorjat porusski. Nekotorye tovarišči xorošo znajut i russkij i anglisjkij jazyk. Vy govorite po-anglisjki, a oni ili special'nye perevodčiki, perevodjat na russkij jazyk. A kodga govorit russkij tovarišč, oni perevodjat na anglisjkij jazyk. No èto ne vpolne udovletvorjaet vas. Vy izučaete russkij jazyk. Teper' ty uže nemnogo čitaeš’ i govoriš’ po-russki, i drugie tovarišči takže. Vy vse ponimaete, kak važno znat' inostrannye jazyki. Ėto znanie ukrepljaet intemacional'nuju spločennost ' proletariata. Rabočie SSSR xorošo ponimajut 
èto. Očen' mnogie rabočie SSSR izučajut anglijskij i drugie inostrannye jazyki. V SSSR est' lozung: "Inostrannye jazyki v massy". (RESW 1933, 58)

'You live in the USSR and work at a plant. At the plant where you work there also are other foreign workers, Englishmen and Americans. As yet all of you know only English well and speak Russian poorly. This hampers your active participation in the life of the community. The other workers at the plant speak Russian. Some comrades know both Russian and English well. You speak in English and they or special interpreters translate into Russian. And when a Russian comrade talks they translate into English. But this is not completely satisfactory. You are leaming Russian. Now you and the other comrades already read and speak a little Russian. All of you understand how important knowledge of foreign languages is. This knowledge promotes the intemational solidarity of the proletariat. Workers in the USSR understand this well. Very many workers in the USSR learn English and other foreign languages. In the USSR there is a slogan: "[Bring] the foreign languages to the masses".'

This effort was short-lived. Although it was never overtly admitted that the relevant group of toilers had shrunk too, the apprehension that became the hallmark of the official position on contacts between Soviet citizens and foreigners is easy to spot in the Russian second-language textbooks produced during that period.

The relevant time span includes the period since the establishment of the Marxist doctrine by Karl Marx (1818-1883) with a handful of selected previous events, preferably revolutions and mass revolts. The perfect embodiment of the Communist sum total of concepts is contained in the History of the Communist Party of the Soviet Union (Bolsheviks). Short Course (English translation 1939) (Glowinski 1996). LRSDA 1933 offers the following selection of readings that show a clear preference for the present over the past: Tovarišč Vorošilov - vożd' Krasnoj Armii 'Comrade Vorošilov - a Leader of the Red Army' (16), Biografija tovarišca Tel'mana 'Comrade [E.] Thälmann's Biography' (19), Demonstracija 'Demonstration' about a rally of workers and unemployed in Berlin (21-22), My stroim sociaističeskoe xozjajstvo 'We Are Building a Socialist Economy' (33), Russkij proletariat stroit noviju żizn' "The Russian Proletariat Is Building a New 
Life' (35), Pjatiletnij plan 'The Five Year Plan' (37), Stroim zavody $i$ èlektrostancii 'We Are Building Plants and Power Stations' (51), Cerez pjat' let 'In Five Years' (57) about the envisioned achievements in industrialization, Biografija Lenina 'Lenin's Biography' $(59-60,61,64,67,69,72)$, Sobranie '[Workers' General] Meeting [at a Plant]' (76), Biografija Rozy Ljuksemburg 'Rosa Luxemburg's Biography' (78-79), Biografija Stalina 'Stalin's Biography' (85-86), Socsorevnovanie $i$ udarničestvo 'Socialist Competition and ShockWorker Movement' (89-90), Kak vypolnjalas' pervaja pjatiletka 'How was the First Five-Year Plan Implemented' (93), MTS 'Machine and Tractor Stations' (95), Zajmy '[Government] Bonds' (96) about workers enthusiastically sponsoring industrialization. Fabrika-kuxnja 'Large-Scale Mechanized Canteen' (100), Malen'kie kommunary 'The Little Communards' (103) about child members of the Paris Commune in 1871, Statistika ekonomičeskix boev 'Statistics of the Economic Battles' (105-106) about strikes in Western Europe, Obrazcy gazetnyx telegramm 'Samples of Newspaper Telegrams' (109-112) about rallies, strikes and violence in the streets of West European cities, Sojuz Sovetskix Socialističeskix Respublik 'The Union of the Soviet Socialist Republics' (113-114), Nakanune pervogo avgusta v kapitalističeskix stranax 'On the Eve of August 1 in the Capitalist Countries' (116-117) about the pacifist movement, Antivoennyj den' pervogo avgusta $v$ kapitalističeskix stranax 'The Anti-War Day August 1 in the Capitalist Countries' (119-122). Vodjanoj gigant 'Water Giant' about the Dneproges power station (128-129, 131-133, 135-139). Cifry georiceskoj bor 'by 'Statistics of the Heroic Struggle' (141) about arrests and prosecution of revolutionaries in the Western world. [M. A.] Svetlov's Pesnja šaxtera 'A Miner's Song' (143), Za čto nenavidjat kapitalisty SSSR 'Why Capitalists Hate the USSR' (145, 147-148), Krasnaja armija 'The Red Army' (149-151), Russkie, ukraincy, nemcy, kirgizy 'Russians, Ukraininans, Germans, Kyrgyz' (153-156) about a prototypical collective farm run by people of different ethnic backgrounds. M. Gor'kij's Vstreča detej 'Welcoming the Children' (158- 
159) about mutual assistance among proletarians in Italy, Libknext i molodež '[K.] Liebknecht and the Young People' (160), Rasskaz šofera Gilja o pokušenii na Lenina 'Driver Gil's Testimony about [Fani Kaplan's] Attempt on Lenin's Life' (162, 164-166), Na kolxoznom bazare 'At the Cooperative Farmer Market' (167), Rol' kolxoznyx bazarov 'The Role of the Cooperative Farmer Markets' (169-170), Sest' uslovij tovarišča Stalina 'Comrade Stalin's Six Conditions' $(172,176)$ about the new priorities in the economy, ltogi pervoj pjatiletki The Outcome of the First Five-Year Plan' (179), Zadači vtoroj pjatiletki 'Tasks of the Second Five-Year Plan' (181-182, 184-185).

As soon as it became clear that the world revolution was not forthcoming and the Soviet state was constrained to build socialism in isolation, Communist discourse stanted to incorporate symbols of the Autocratic discourse, which could serve its purposes. It is well known that among the few monarchs of Russia in favour during Stalin's time were Ivan the Terrible and Peter I, a preference reflected in my collection of textbooks. RMLR 1947 obediently includes a story about Peter I (RMLR 1947, 312-314) and the following dialogue:

(158) - Chto smotreli?

- Dramu "Ivan Groznyj".

- Zaviduju. Ja slyšala, čto èto očen ' interesnaja p'esa. Ona idet uže davno, a bilety vse-taki dostat' trudno.

- Da, p'esa, dejstvitel'no očen' interesnaja. Pokazyvaetsja èpoxa, kogda šla bor'ba za edinoe nusskoe gosudarstvo, kogda sozdavalas' velikaja russkaja deržava. (RMLR 1947, 138)

".What did you witch?"

"The drama lvan the Terrible."

"I envy you. I have heard that this is a very interesting play. It has been on for a long time now but it is still difficult to get tickets."

"Yes, the play is very interesting indeed. It shows the period when a fight was going on for a united Russian state, when Russia was establishing itself as a great world power."

Thus, the mature (Stalinist and post-Stalinist) Communist discourse can already be seen as a synthesis, albeit of a limited nature. In its spirit, even 
Orthodox Christianity was vindicated for a while during the Second World War to make sure that the entire population was rallied to fight against the German invaders. The Communist attempt at synthesis was preceded by the synthesis achieved by the Autocratic discourse. It includes Orthodox Christianity, the essence of the Holy Rus doxa, along with autocracy and nationality, as one of its three principles, but religion is here subordinated to the needs of autocracy. The Autocratic discourse also internalized the lessons taught by the Civilized-World doxa. Its relevant territory is Russia, the group is the Russian nation, and the period starts with the beginning of Russian statehood and lasts until the moment of speaking. An idea of what the Autocratic sum total was like is provided in RS III 1898 with its readings on topics like Otkuda slavjane 'Where did the Slavs come from' (109-110); Prizvanie knjazej 'Invitation of the [Varangian] Princes' (110); Oleg 879-912 (110-111) about Prince Oleg of Novgorod, the founder of Kievan Rus; Smert' Olega 'Oleg's Death' (111); Svjataja Ol'ga 945-957 (111112) about St.Olga, the first ruler of Rus to become Christian; Krešćenie Vladimira i kievljan 'The Baptism of [Prince] Vladimir and the Kievans' (112113); Jaroslav Mudryj 1019-1054 (115-116) about Prince Jaroslav the Wise who brought Kievan Rus to its peak: Našestvie tatar 'The Tatar [Mongol] Invasion' (116); Aleksandr Nevskij (116-117) about the Novgorod Prince canonized for his victory over Germanic invaders in 1240; Kulikovskaja bitva "The Kulikovo Battle [in 1380 over the Mongols]' (117-118); Ennak i pokorenie Sibiri '[The Cossack Leader] Ermak and the Conquest of Siberia [by 1583]' (118-119); Izbranie na carstvo Mixaila Fedorovica Romanova 'Election of Mixail Fedorovic Romanov to the Throne [in 1613]' (119); Ivan Susanin (120-121) about the Russian peasant who misled the Polish army trying to abduct the Tsar and saved his life with the price of his own; Petr Velikij 1682-1725 'Peter the Great' (122-123); Kak Petr naćal ucit'sja gramote 'How Peter Started Learning the Letters' (124); Neustrašimost' Petra Velikago 'Peter the Great's Courage' (124); Istorija odnogo domika (Domik Petra I) 'The Story of a Small House (Peter I's House)' (126); 
Ekaterina II Velikaja 1762-1796 'Catherine the Great' (126-127); Lomonosov (127-129) about the great encyclopedic scholar of the eighteenth century; Suvorov (129-132) about the ever-victorious eighteenth-century general; Aleksandr Blagoslovennyj [1801-1825] i Otećestvennaja vojna 'Alexander the Blessed and the Patriotic War [against Napoleon in 1812]' (132-133); $M$. Lermontov's poem Borodino about the battle with Napoleon in Borodino (133135); Pożar Moskvy 'The Moscow Fire [during Napoleon's invasion in 1812]' (135); Velikodušnyj postupok Imperatora Aleksandra I 'Emperor Alexander I's Magnanimous Act' (136-137) tells how he saved a man from drowning; Nikolaj I i Sevastopol'skaja oborona 'Nicholas I and the Defence of Sevastopol [during the Crimean War in 1853-1856]' (137-138); Car'-Osvoboditel' 1855-1881 '[Alexander II] The Tsar Liberator', called so because of the emancipation of the serfs in 1861 (138-141); Imperator Aleksandr III 1881-1894 'Emperor Alexander II' (141-144), a story that introduces at the end Nicholas II; Gimn Russkomu Carju 'Anthem to the Russian Tsar' (144).

The orthodox discourse of our time, the Bridging discourse, aims to make the best out of everything that Russia has put forward, which transforms it into a synthesis of the non-Communist heterodox discourses of the Imperial period with the Dissident heterodox discourse of the Soviet period. It combines a critical stance of the near Communist past with anxiety provoked by the unsettling innovations of the present and enthusiasm for the Imperial past. This perspective is visible in passages like the following:

(159) Zdes' mnogo staryx zdanij. Oni ukrašajut gorod. Vot Kreml'. Kakoj on krasivyj! No zdes' est' i mnogo novyx domov i kioskov. Oni portjat vpečatlenie ot goroda, potomu čto okolo nix mnogo grjazi. Tak čto Moskva velikolepnyj i v tože vremja urodlivyj gorod. (RJaV 1995, 63)

'There are many old buildings here. They adorn the city. Here is the Kremlin. How beautiful it is! But there also are many new buildings and kiosks here. They mar the impression from the city because there is a lot of dirt around them. Thus Moscow is a magnificent and at the same time disagreeable city.' 
The Bridging discourse differs from the Slavophile discourse by its lack of religiosity and its more pronounced pro-Western orientation. But it is not identical with the Westernizer discourse either, because it shares with the Slavophile discourse its admiration for the Russian people (narod). So its territory is Russia, the relevant group is the Russian nation and the time period opens with the first records of Slavs in this territory. Out of the three principles of the Autocratic discourse, only Nationality seems to have kept its significance. Autocracy is tolerated but seen with a critical eye (see, for instance, RB 1999, 269). The fervent religiosity of the Autocratic discourse as demonstrated in (160), to (164) is contrasted in the Bridging discourse with its use of Christian symbols as signs of Russianness or spiritual revival.

(160) Tut Knjaz' Sujskij, oblityj krov'ju, sxodit s ranennago konja, uderživaet otstupajuščix, pokazyvaet im obraz Bogomateri i mošci Sv. VsevolodaGavriila, nesomyja Ierejami iz Sobornago xrama: svedav, čto Litva uže v bašnjax i na stene, oni šli s seju svjatyneju, v samyj pyl bitvy, umeret' ili spasti gorod Nebesnym vdoxnoveniem mužestva. Rossijane ukrepilis' v duxe: stali nepokolebimy... (RX 1848,7)

'At this moment Prince Šujskij, covered in blood. stepped down from the wounded horse, stopped those retreating and showed them the icon of God's Mother and the relics of St. Vsevolod-Gavniil, carried by the Hierarchs from the Cathedral. Having heard that the Lithuanians were already in the towers and on the wall, they were going with the sacred objects into the thick of the battle to die or save the city with courage inspired from Heaven. The Russians stiffened in their spirit and stand firm...'

(161) “Ax, milyj Leša, ncuželi ty dumaeš’, čto v pogrebe nikto nas ne uvidit... Razve ty ne znaeš' o Tom, Kto vidit cerez steny $i$ ot Kotorago $i$ v temnote nel'zja skryt"sja." Leša ispugalsja. "Pravda tvoja. sestrica," skazal on. "Bog nas vidit. Ne budem že nikogda delat' togo, 'ego ne sleduet." (KC I888, 3)

"..'Oh dear Leša, do you really think that no one will see us in the cellar... Don't you know of Him, Who sees through walls and from Whom you cannot hide even in the dark." Leša was scared. "You are right, sister," he said. "God sees us. Let us never do what we ought not do."

(162) Kogda ty v"ezžacš $v$ selo. čto prežde vsego tebe brosaetsja $\vee$ glaza? Cerkov'! Stoit ona vyše vsex domov, ni na odin dom ona ne poxoža. Ni v 
odin dom ne pojdut mirjane vsego sela, a $v$ cerkvi mesto dlja vsex est': $i$ staromu u malomu, i bogatomu i bednomu, i zdorovomu i bol'nomu. Vse ravno predstojat pred Gospodom. V cerkvi tebja krestili, v cerkov' tebja prinesut, kogda otdaš' dušu Bogu. Blizko cerkvi tebja poxoronjat. Slovom, čto by važnago $v$ tvoej žizni ni slučilos', vo vsem tebe pomogaet cerkov'. I ne tebe odnomu; posmotri, vokrug cerkvi ležat otcy tvoi, dedy i pradedy. Vse oni v cerkvi krestilis', żenilis', prinosili krestit' svoix detej. Vse oni tam molilis', gde ty moliš'sja. Stalo byt' cerkov' ne to, čto vsjakij drugoj dom. V inoj dom ty sam ne pojdeš', $v$ inoj tebja ne pustjat. $V$ inom dome $u$ tebja drug, $v$ inom vrag. No $v$ cerkov' Božiju vse vxodjat: i znakomye, i neznakomye, $i$ rodnye $i$ nerodnye, $i$ drugi $i$ nedrugi, $i$ často vragi, predstoja $v$ odno vremja pred prestolom Božiim, umiljajutsja serdcem i zabyvajut ob obidax. (KC $1888,36-37$ )

'When you arrive in a village, what is the first thing that strikes you? The Church! It is taller than all houses and does not look like any one of them. All village laymen won't enter any one house but there is room for all of them in the church: old and young, rich and poor, healthy and ill. All are equal before the Lord. You were christened in the church; you will be brought here when you pass away. You will be buried near the church. In one word, the church will help you in any important event of your life. And not only you. Look, your parents. grandparents and grandgrandparents are lying around the church. They all were christened in the church, wed and brought their own children to be christened. They all prayed where you are praying. This shows that the church is not like the other houses. There are houses, to which you won't go, in others you will not be allowed to go. In some houses you have friends, in others enemies. But everybody goes into God's church, acquaintances and strangers, kin and unrelated people, friends and opponents and even enemies; they all stand at the same time before God's throne and their hearts are moved and they forget their grudges.'

(163) "Skaži mne, rodnaja, otkuda vse èto beretsja: i èti derev'ja, i rečka, čto bystro tak l'etsja, i èti plody, i cvety po lugam, i pticy, i ryby, i vse, čto živet i cvetet - otkuda vse èto beretsja, skaži mne, otkuda?" - Vse èto ot Boga, moj angel idet. (RS I 1896, 87)

"Tell me, darling, where does all of this come from: these trees and the river that flows so quickly, and thesc fruits, and the flowers on the meadows, the birds and the fish and everything that lives and blossoms. Where does this all come from, tell me, where?" "All this, my angel, comes from God."'

(164) Sredi žarkago leta, po goristoj, usejannoj kamnjami doroge šel bednyj čelovek. Šel, šel, izmučilsja, porezal sebe nogi ob ostrye kamni. I vot stal roptat' na Boga, počemu on takoj bednyj, čto daže ne $v$ sostojanii kupit' sebe 
obuvi. Vdrug ètot bednjak vidit - vezut na teležke celoveka sovsem bez nog. "O, čto by ètot nesčastnyj kaleka dal," podumal bosoj bednjak, "esli-b emu vozvratili ego nogi!" i pobežal bednjak $v$ cerkov', pal na koleni i dolgo gorjač molilsja Bogu. S togo vremeni on nikogda ne roptal na Boga. (DD 1902,83 )

'A poor man was walking on a hot summer day along a hilly road scattered with stones. He was walking for a long time; he was exhausted and he had cut his feet on the jagged rocks. And here he started to grumble at God. why was he so poor that he could not even buy shoes. All of a sudden the poor man saw a man without legs carted past him. "I wonder," the poor barefoot man thought, "what would this wretched cripple give to have his legs returned to him?" Then he ran to the church, fell on his knees and for a long time prayed fervently to God. After that he never grumbled at God.'

Orthodox Christianity certainly has its staunch supporters in contemporary Russia, but they are obviously not in the business of writing second-language textbooks. The only passages known to me that are written with an authentic religious feeling and included against a pluralist religious background in a post-Soviet second-language textbook are those by Sergej Zubatov and Aleksandr Men' in LTL 1996, 153-154, 156-159. The Bridging discourse values not religiosity per se but the freedom to believe what one chooses to believe:

(165) Anton: - Maša, a ty verujušcaja?

Maša: - Verju li ja v Boga? Trudno skazat'. Skoree, net. No ja priznaju pravo každogo čeloveka vybirat' - verit' emu ili ne verit'.

Anton: - Stranno ty govoris’. Kto že eščc možet rešat' za čeloveka?

Maša: - Tebe ètogo ne ponjat'. U nas tak bylo do nedavnego vremeni. Sejčas $\vee$ Moskve živut ljudi raznyx veroispovedanij. Teper' oni mogut besprepjatsivenno ispovedovat' svoju religiju - islam, buddizm, xristianstvo. (RJaV 1995, 287-288)

"Anton: "Maša, are you a devout Christian?"

Maša: "Do I believe in God? I am not sure. Probably not. But I recognize the right of every person to choose whether to believe or not."

Anton: "What you say is odd. Who clse can decide for a person?"

Masa: "It is difficult for you to understand. That is how things were in our country until recently. People of different denominations now live in Moscow. They can practice their religion without obstruction - be it Islam, Buddhism or Christianity." 
Indeed. the Bridging discourse opposes in this regard all its predecessors except the Civilized-World doxa but most poignantly the Communist discourse, which ignores religion completely, as demonstrated in my collection of secondlanguage textbooks and beyond, if we do not take into account the occasional deliberate attempt to pit the people against the Church:

(166) Na čto šli narodnye den'gi. Do Velikoj Proletarskoj revoljucii popy imeli 2 milliona 850 tysjač gektarov zemli. Oni vladeli i doxodnymi domami. Tak, v odnoj Moskve bylo 908 cerkovnyx domov. Glavnyj pop - mitropolit Peterburgskij - polučal 289 tysjaž rublej $v$ god žalovan'ja, novgorodskij arxiepiskop - 308 tysjač rublej, moskovskij mitropolit - 81 tysjažu rublej, kievskij mitropolit - 84 tysjaci rublej. (MLR 1938, 2:76)

'What was people's money spent on? Before the Great proletarian revolution priests had 2,850,000 hectares of land. They were also renting out apartments. In Moscow alone there were 908 buildings owned by the church. The main priest, the St. Petersburg metropolitan, had an annual revenue of 289,000 roubles, the Novgorod archbishop 308.000 roubles, the Moscow metropolitan 81,000 roubles and the Kiev metropolitan 84,000 roubles.'

This silence is understandable given the discursive incompatibility of religion and Communist ideology. Here is a typical Communist statement cited maliciously by proponents of the Dissident discourse:

(167) S likvidaciej èkspluatatorskogo stroja uničtožajutsja social'nye osnovy xristianstva, a ono soxranjaetsja liš' kak perežitok prošlogo, iš̌ezajuščij v processe postroenija kommunističeskogo obక̌čestva. (AR 1980, 300)

'The social basis of Christianity is destroyed with the liquidation of the exploitatory regime. Christianity itself is preserved only as a relic of the past which gradually disappears in the process of construction of the Communist society.'

AR 1980 expresses its disagreement with the Soviet treatment of religion through the comments of Żanna, an American graduate student who attends a standard university lecture on scientific atheism. Significant is the contrast with the stance taken by her Russian friend Kolja. While Żanna is appalled, Kolja 
takes the system for granted and goes on with his life without committing himself one way or another.

The opposition to Communist discourse on the issue of religion is put up by both the Dissident and the Bridging discourse from agnostic positions. If they look at religion at all, it is from the perspective of their own priorities and not for its sake. When they come across issues that have a religious dimension, textbooks adhering to the Bridging discourse frequently de-emphasize and misinterpret it, as in (168), or completely dismiss it, as in (169):

(168) Est' starinnaja russkaja poslovica: "Poka grom ne grjanet, mužik ne perekrestitsja". Ona osnovana na predstavlenijax neobrazovannyx, no religioznyx ljudej o tom, čto kogda gremit grom, èto značit, čto prorok Il'ja grozit ljudjam, ne pomnjaščim Boga. Potomu, uslyšav grom, èti ljudi krestilis', kak by pokazyvaja, čto oni pomnjat o Boge. (RJaV 1995, 234)

-There is an old Russian proverb: "A peasant does not make the sign of the cross until it thunders". It is based on the views of uneducated but religious people that when it thunders, this means that the prophet Elija is threatening the people who have forgotten God. That is why these people were making the sign of the cross as if showing that they remembered God.'

(169) Deržavnoj mošč'ju veet ot Uspenskogo sobora, stojaščego za kremlevskoj stenoj, gde nekogda sobiralos' rostovskoe veče. I xotja èta gromada, poražajušcaja blagorodstvom linij, spokojstviem i soveršenstvom proporcij, stroilas' dlja utverždenija boga, glavnoe, čto ona voplotila v sebe, - sila duxa i bezuprečnyj vkus ljudej, tvorivšix ee. (RJaV 1995, 339-340)

'The Assumption Cathedral behind the [Rostov] Kremlin walls, where long ago the Rostov popular assembly used to meet, leaves the impression of stately might. And although this bulk of a building of staggeringly noble lines, calm and perfect proportions, was built to assert God, it first and foremost embodies the spiritual strength and the irreproachable taste of the people who created it.'

The tendency to minimalize Christianity was apparent from the transitional period to post-Communism. Even in discussing maslenica 'Shrovetide' RST 1985 manages not to mention it, examining instead in detail Shrovetide's pre-Christian roots and treating it not as a relic embraced by Christianity, but as a pagan festival in its own right. This continues to be an 
attractive approach, as demonstrated by the presentation of maslenica as a festival whose sole purpose is to see winter off (DDP 1995 8:11-13).

Further examples of synthesis are provided by the Reconciliatory discourses of the Soviet and the post-Soviet periods. They are characterized by a grudging acceptance of the status quo, which they view from the perspective of the period that has just elapsed. Their goal is to salvage as much as possible from the heritage of the previous period. This is what makes it possible to include into the syntagmatic chains symbols from two sum totals. I shall illustrate each type of Reconciliatory discourse with one textbook: CR 1948 and RB 1999.

George Znamensky, the émigré author of CR 1948, is proud of Russian high culture and the Russian language and eager to emphasize the contributions of Russians to Western culture, but he is more aware of the nineteenth-century Russian figures than of his contemporaries. He is silent on Soviet political life: Stalin is never mentioned and Lenin only to explain the new name of Petrograd. He does mention Soviet achievements in music and ballet and he is impressed with the industrialization of the country:

(170) Kogda moja sestra napišet dissertaciju, pročitaet russkix klassikov, izučit drevnie jazyki i naučitsja francuzskomu, ispanskomu i nemeckomu jazykam, a ja proslušaju kurs lekcij na medicinskom fakul'tete i polužu stepen' doktora mediciny, togda my poedem s sestroj v Rossiju, v Sovetskij Sojuz. Tam my budem ezdit' po glavnym gorodam i centram Rossii i nepremenno s"ezdim $v$ Kiev, v Rostov na Donu, $v$ Sevastopol' $i$ v Jaltu. My poedem v Sibir', na Ural, i na Kavkaz. My osmotrim zavody, gde delajutsja avtomobili, mašiny, traktory, vagony, parovozy, aèroplany ili samolety i strojatsja paroxody. My posetim te mesta, gde dobyvajutsja mineraly, metally kak naprimer: zoloto, screbro, platina, med', železo, i drugie metally. My budem znakomit'sja s transportom, s èkonomičeskim, agrikul'turnym $i$ industrial'nym ili promyšlennym razvitiem strany. (CR 1948 53)

'When my sister writes her dissertation, reads the Russian classics, learns the ancient languages, French, Spanish and German and I graduate from the Faculty of Medicine and am granted an MD, then my sister and I will go to Russia, to the Soviet Union. We will travel to the main cities and centres of Russia and we will certainly visit Kiev, Rostov on Don, Sevastopol and Yalta. We will go to Siberia, the Ural Mountains and the Caucasus. We will see the plants where cars, machines, tractors, wagons, engines, airplanes and 
steamboats are built. We will visit sites in which minerals and such metals as gold, silver, platinum, copper, iron and others are extracted. We will get acquainted with the transportation, the economic, agricultural and industrial development of the country.'

It is very characteristic that Znamensky mentions in (170) the old and the new names of the country side by side, something never done by Soviet authors. He is eclectic in his illustrations too: he shows several photos of the new industrial city Magnitogorsk, a showcase of Stalinist Russia, side by side with an icon of the Mother of God. He is fond of folk an and features down-to-earth respect for religious ritual:

(171) Russkie tak že, kak i amerikancy, pozdravljajut drug druga s prazdnikami i so dnem roždenija, a krome togo $i$ so dnem angela, vyražaja pri ètom celys rjad dobryx poželanij, a glavnoe - poželanija zdorov'ja, sčast'ja, uspexa $v$ delax $\mathrm{i}$ voobšče vsjakogo blagopolučija $v$ žizni. Pozdravljaja drug druga $s$ prazdnikami Roždestva Xristova i Novogo Goda, russkie ljudi i v pozdravite'nyx pis'max ili otkrytkax. i pri ličnoj vstreče drug $s$ drugom obyknovenno privetstvujut drug druga slovami: "S Roždestvom Xristovym!" "S Novym Godom!" Na Pasxu že, pri vstreče drug s drugom pravoslavnye russkie vosklicajut: "Xristos Voskrese!" i otvečajut: "Voistinu Voskrese!" Inogda že prosto govorjat "S prazdnikom Svjatoj Pasxi!" (CR 1948, 77-78)

'Similar to Americans, Russians congratulate each other with the holidays and birthdays as well as with the nameday, offering a whole series of wishes. and most importantly they wish each other health, happiness, success in all enterprises and in general prosperity in life. When they greet each other at Christmas and New Year in letters and cards as well as in face-to-face encounters, Russian people usually say "Congratulations on Christ's Nativity! [Merry Christmas!]" "Happy New Year!" At Easter, when they meet each other, Orthodox Russians exclaim: "Christ is risen!" and answer: "Indeed, he is risen!" Sometimes they just say: "Happy Holy Easter!"”

The differences between the Soviet Reconciliatory discourse and its contemporary Communist discourse stem from differences in chronological depth and the relevant group, which are for Znamensky much broader, as he includes all Russian émigrés regardless of ethnic background into the relevant group and 
embraces Russian history since inception. On the other hand, his presentation of Soviet symbols is selective and at best sketchy.

The post-Soviet author Julija Ovsienko (RB 1999) makes an attempt to form a hybrid of the Communist and the Bridging discourses. It is more her tone and what she omits to say than what she actually says that give her away as a representative of the Reconciliatory discourse. In tune with the Bridging discourse, she is moved by the romantic love between White Admiral Kolchak and his wife (RB 1999, 394-396) and by the restoration of Christ the Saviour Cathedral in Moscow (RB 1999, 393-394). She discusses Christmas among the holidays (RB 1999, 358) and Annunciation in connection with A. S. Puškin's poem Pticka 'Bird' (RB 1999, 261). At the same time she includes a relatively high proportion of stories with a characteristic Communist flavour, even an adaptation of M. Gor'kij's Serdce Danko 'Danko's Heart' (RB 1999, 370-371). She systematically avoids mentioning any facts that would open the readers' eyes to conflicts and difficulties that her characters may have gone through in Soviet times, as her treatment of Bulat Okudžava and Sergej Esenin shows (RB 1999, 303-305; 188-189). Thus, she disguises their achievements as a Soviet contribution to Russian culture.

The comparison between the post-Soviet Reconciliatory and the Bridging discourses shows that the difference between them stems from the different ratio of Soviet time events deemed to be relevant by these two discourses and recognized by them as Soviet. The Bridging discourse typically strives to link even indisputably Soviet achievements to their pre-Soviet roots, as this presentation of the Moscow subway demonstrates:

(172) V nacale XX veka cleny Gosudarstvennoj rossijskoj dumy ne prinjali proekt moskovskogo metro. "Pod moim domom prorojut tonnel", po kotoromu budut ezdit' i šumet' poezda? - vozmuščalis' oni. - Ėtomu ne byvat'!" $K$ idee metro vernulis' tol'ko v 30-e gody. (P 2 1996, 21-22)

'At the beginning of the twentieth century the members of the Russian State Duma voted against the project of the Moscow subway. "Dig a tunnel under 
my home through which noisy trains will be passing?" They were appalled.

"Never!" People retumed to the idea about a subway only in the 1930s."

Let us now return to the notion of valuable sum totals of concepts, as varying as they were shown to be. and their representation by a summarizing symbol. I assumed that any identity discourse would by definition place value on the whole that forms its basis since identity is affiliation of Self with Self's "own" whole defined in terms of time and space, an affiliation shared with other people who have defined their identity in a similar way. These same people populate Self's space and perform in time actions that shape the whole.

For identity purposes, time is indistinguishable from the events that take place in it. The sequence of relevant events has its own internal logic. The chronological label attached to each event only provides a different perspective on the sequence. The cult of Self's time as delineated by those events is first of all visible in the celebration of anniversaries, and particularly of the anniversary of the beginning of the relevant period. Altematively, the temporal whole may be represented by the event that forms its highest peak, which in such a case transforms into a metonymical summarizing symbol. Any event that has transformed into a summarizing symbol of Self's time will also be celebrated annually.

The importance of holidays pertaining to the whole for the identity of Self cannot be overestimated. Predictably, each identity discourse has its own set of holidays. Let us outline the sets of holidays by discourse. The Autocratic discourse recognizes holidays that come from two sources: Orthodox Christianity and events related to the personality of monarchs:

(173) Svjataja cerkov' neprestanno, pri každom bogosluženii, molitsja za Carja, Ego sem'ju i ves' Carstvujuščij dom. No krome togo est' osobye prazdniki, v kotorye soveršaetsja toržestvennoe molebstvie o Gosudare i Ego Avgustejšzj sem'e. Éti prazdniki nazyvajutsja Carskimi dnjami. $K$ čislu glavnejšix Carskix dnej otnosjatsja: dm rożdenija i tezoimenitstva Gosudarja Imperatora. Gosudaryni Imperatricy i Gosudarja Naslednika, a takže den' voš̌estvija na 
prestol Gosudarja Imperatora i den' svjaščennago koronovanija Ix Imperatorskix Veličestv Gosudarja Imperatora $i$ Gosudaryni Imperatricy. (DD 1902, 113-114; similar account in RR I 1914, 74)

'The holy church prays for the Tsar, His family and the whole ruling dynasty incessantly, at every church service. But besides that, there also are special holidays when there is a solemn liturgy about the Sovereign and His August family. These holidays are called Tsar's days. The most important Tsar's days are the birthdays and the namedays of His Majesty the Emperor, Her Majesty the Empress and His Highness the Heir to the throne. as well as the anniversary of the accession to the throne of His Majesty the Emperor and that of the coronation of their Majesties the Emperor and the Empress.'

All these holidays were abolished during Soviet times and replaced in the Communist discourse with a new set, the most prominent of which was November 7, the Day of the October Revolution. Quotation (174) gives an idea of the early, more personal approach to this holiday, which later was standardized, as shown in (175):

(174) Kak naša škola gotovilas' ko dnju godovščiny Oktjabr'skoj revoljucii. Prigotovlenija načalis' zadolgo do prazdnika. Vse v ètom dele prinjali učastie. Lučšie risoval'šciki gotovili plakaty. Mitja Ėliašvili narisoval šaxtera s kirkoju, a sboku krupno napečatal: "Trud naš otec, sčast'ja kuznec!" Otar Nemsadze izobrazil paxarja i kuzneca, a meždu nimi pomestil plakat: "Gorod s fabrikami i zavodami šlet $v$ derevnju plugi, serpy, sejalki, topory, pily, tkani raznye, a derevnja daet gorodu xleb, kartofel', maslo. Dcrevnja s gorodom idut ruka ob ruku". Za dva dnja do prazdnika i my, malyši, vdovol' potrudilis': pleli iz elovyx vetvej girljandy, vymeli lužajku vozle skoly, dorožku usypali želtym peskom. Rabotali veselo, družno, ne znali ustali. Celuju nedelju ustraivalis' spevki, čtob vse zaučili "pesn' truda". I slavno że my spelis'! (ŽS 1926, 74)

'How our school prepared for the anniversary of the October Revolution. The preparations started long before the holiday. Everybody took part in them. The best draftsmen made posters. Mitja Ėliašvili drew a miner with a pick and printed on the side with large letters "Labour is our father, the blacksmith of our happiness!" Otar Nemsadze depicted a ploughman and a blachsmith and between them the slogan: "The city with its factories and plants sends to the countryside ploughs, sickles, seeding machines, axes. saws anci various fabrics, whereas the countryside gives to the city wheat. potatscs at d butter. 
The countryside and the city go hand in hand." Two days before the festival we, the youngsters, also put up some work to our hearts' content: we twined garlands from fir branches, swept the lawn by the school and bestrewed the path with yellow sand. We worked together joyfully and tirelessly. We rehearsed for a whole week the "Song about Labour". And how wonderfully we learned to sing together!'

(175) 7 nojabrja u sovetskix ljudej bol’šoj prazdnik. Ves' sovetskij narod prazdnuct godovščinu Velikoj Oktjabr'skoj socialističeskoj revoljucii. V ėtot den' $v$ Moskve na Krasnoj ploščadi $v 10$ Casov načinaetsja voennyj parad. Posle parada - demonstracija. V demonstracii učastvujut trudjaščiesja Moskvy, sovetskie studenty i skol'niki, a takže inostrannye studenty, kotorye učatsja $\vee$ Moskve. [...] Ljudi smejalis', peli, tancevali. Igral orkestr. Na stenax domov viseli portrety, plakaty, flagi. "Miru - mir!", "Slava trudu!", "Da zdravstvuet Velikaja Oktjabr'skaja socialističeskaja revoljucija!" - čitali studenty. Vse ždali načala demonstracii... [...] Nakonec, Krasnaja ploščad'. Ljudi idut po Krasnoj ploščadi mimo Mavzoleja V. I. Lenina, privetstvujut Sovetskoe pravitel'stvo. (URJa 1969, 1:271-272)

'The Soviet people have a big holiday on November 7. The entire Soviet nation celebrates the anniversary of the Great October Socialist Revolution. A military parade begins on the Red Square on that day at ten o'clock. After the parade there is a demonstration. Moscow working people. Soviet students and schoolchildren, as well as foreign students who study in Moscow take part in the demonstration. [...] People were laughing, singing and dancing. A band was playing. On the walls of the buildings there were portraits, posters and flags. Students read: "Peace to the world!" "Glory to labour!" "Long live the Great October Socialist Revolution!" Everybody was waiting for the beginning of the demonstration... [...] At last, the Red Square. People are walking along the Red Square past Lenin's Mausoleum and greeting the Soviet Government.'

The entire list of Soviet holidays as it was at the end of the period is available in RST 1985, 218. The lists in RJaV 1995, 382-383 and the discussions in MPMR 1998, 83-85 and DGR 2000, 233-234 make it clear that the most important innovation of the Bridging discourse was a return to the Orthodox Christian holidays of the Imperial period. In other words, the patronage of saints over people. events, institutions and territories is emphasized once again. Thus, we are reminded that St. George is the patron of Moscow (P 2 1996, 6) and St. 
Tat'jana is the patron of the Moscow University (P 2 1996, 48). Christian holidays are now, however, superimposed on the Soviet holidays, all of which were preserved as statutory days off. Among them, the most emotionally charged and consensually valued holiday is May 9, Victory Day in the Second World War, known in Russia as Velikaja Otećestvennaja vojna the Great Patriotic War'. The unwavering importance of the victory in the Second World War in competing identity discourses is attested over and over again in numerous stories: for example, RTRL 1945, 69-70 (repeated in RMLR 1947, 62), 125, 145, 151152 (repeated in RMLR 1947, 154); RMLR 1947, 229, 296; RJa 1952, 64, 80-81, 88, 118; RJaSI 1970, 307-308, 314-315; DDP 1995, 8:3-4; RB 1999, 314-316.

Jubilees (and especially $100^{\text {th }}$ jubilees) stand out among annual celebrations. Thus, imperial Russia celebrated with pomp the $300^{\text {th }}$ anniversary of the Romanov dynasty in 1913, the Soviet Union the $50^{\text {th }}$ anniversary of the October Revolution in 1967 and, marking the turning point towards a new discourse, the $1000^{\text {th }}$ anniversary of Russia's Baptism in 1988. The Bridging discourse also used the $850^{\text {th }}$ anniversary of Moscow in 1997 and the $300^{\text {th }}$ anniversary of St. Petersburg in 2003 to consolidate itself. A cultural constant are the A. S. Puškin (1799-1837) jubilees, which are a feature of all periods and discourses: the years 1899, 1937 and 1999 were marked by veritable explosions of Puškin-related publications and festivities. Due to its orientation to the habitual rather than the momentary, the SLL discursive formation prefers to reflect annual holidays rather than jubilees, but note the following quotation in which the reader's attention is focused on the building of a monument that immortalizes the fleeting moment of the jubilee:

(176) Togda [i.e. v 862 godu] prišli tri brata: Rjurik, Sineus i Truvor s rodstvennikami svoimi i družinoju (vojskom) [...] $S$ tex por i ustanovilsja gosudarstvennyj porjadok $u$ našix predkov slavjan. Vot počemu načalo russkago gosudarstva sčitajut s 862 goda. V 1862 godu v Velikom Novgorode byl postavlen pamjatnik tysjačeletıju Rossii. (RS III 1907. 137)

'Three brothers. Rjurik, Sineus and Truvor, together with their kin mien and their troops came then [in 862]. [...] It was at that time that cur Slavic 
ancestors acquired a state organization. That is why the year 862 is considered to be the beginning of the Russian state. A monument to the one thousandth jubilee of Russia was erected in Great Novgorod in 1862.'

Annual holidays, anniversaries and jubilees (different for different discourses) are the metonymical summarizing symbols of Russia and the Soviet Union in time. A readily evoked metaphorical summarizing symbol of Russian time is winter, which counts both among insiders and outsiders as the most Russian time of the year:

(177) Esli sprosit' $u$ inostrancev, s čem u nix associiruetsja Rossija, to často možno uslyšat' takoj otvet: s morozami, snegom, xolodom. Ėto tradicionnoe zapadnoe predstavlenie o našej pogode. Ėto tak i ne tak odnovremenno. [...] Konečno, zimoj, esli sravnivat' s bol'šinstvom stran Evropy, $v$ Rossii xolodnec. [...] Russkie očen' ljubjat zimnee vremja, pervyj čistyj sneg. Mnogie russkie pisateli posvjaščali zime svoi lučšie liričeskie stixotvorenija. [...] Tak cto pust' vas ne pugact russkaja pogoda. Ona vo mnogom napominaet pogodu $v$ central 'nyx evropejskix stranax. No, esli vdrug vam ne povezet, i pogoda $v$ étom godu budet osobenno xolodnoj, ne rasstraivajtes'. Vernuvšis' domoj, vy smožete smelo skazat', čto znaete, čto takoe russkie xoloda. (MPMR 1998, 99)

'If one asks foreigners what they associate Russia with, one frequently hears the answer: with frosts, snow and cold. This is the traditional Westem view of our weather. This is true and untrue at the same time. [...] Of course, winter in Russia is colder than in most European countries. [...] Russians love winter very much, the first pure white snow. Many Russian writers dedicated to winter their best lyrical poems. [...] So, do not get scared of Russian winter. It is very similar to the weather in the central European countries. But if you are out of luck and the weather this year happens to be particularly cold, do not despair. When you return home, you will be able to declare proudly that now you know what Russian cold is like.'

Indecd, my collection of Russian textbooks promotes both in image and narrative a luminous, optimistic perception of winter. The beauty of winter is praised in prose and verse (e.g., RS II 1908, 68; RS III 1907, 130; RR III 1914, 121: RKG 1931, 167; MLR 1938, 2:38, 49; URJa 1973, 2:94-95; RST 1985, 47. 57). The dim outsider view, on the other hand, seems to have been reinforced by the similar winter experiences of two invading armies: that of Napoleon in 1812 
and that of Hitler during World War II. As the military historian A. I. Mixajlovskij-Danilevskij (1790-1848) bitterly remarks, the harshness of Russian winter was unfairly evoked to explain away defeat due to miscalculations and the underestimation of Russians as adversary:

(178) Siljas' otnjat' u Russkix cest' pobedy, Napoleon, a za nim vse francuzskie pisateli ložno pripisali svoi bedstvija isključitel'no svireposti stixij. Pervyj sneg vypal na drugoj den' posle vjazemskogo sraženija 23-go oktjabrja, a zima stala 25-go, okolo Dorogobuža, 18 dnej posle togo, kogda Francuzy podnjalis' iz Moskvy, kak ispugannyja vorony s orlinago gnezda. Stuža deržalas' 5 dnej, potom umen'šilas', ne prevyšaja do Krasnago $8^{\circ}$, a ot Krasnago do Orši otteplelo i bylo poperemenno do 2-x i ne bolee 4-x gradusov. No na pervyx 18-ti maršax iz Moskvy k Vjaz'me neprijatel' byl uže doveden golodom do takogo iznemoženija, čto esliby i ne zastigla ego stuža, to i v takom slučae ne mog by on bez ogromnyx poter' dojti do Orši, tem bolee, čto $v$ puti podvergalsja napadenijam sperva našix lekgix vojsk, a posle pod Vjaz'moju i Krasnym dolžen byl vyderživat' ataki celyx korpusov. Sledstvenno ne moroz, no nedostatok $v$ pišce byl pervoju pričinoju razrušenija glavnoj neprijatel'skoj armii, posledovavšago ot Moskvy do Orši i doveršennago poraženijami i xolodom. (RX 1872, 172-173)

'In an effort to rob the Russians of the honour of the victory, Napoleon and after him all French writers unfairly ascribed all his misfortunes to the rage of the elements. The first snow fell on the next day after the battle at Vjaz'ma on October 23 and the winter set in on the $25^{\text {th }}$ when the French were around Dorogobuž, eighteen days after they had taken off from Moscow like scared crows from an eagle's nest. The frost lasted for five days and then subsided, not exceeding $-8^{\circ} \mathrm{C}$ until they reached Krasnyj. From Karsnyj to Orša there was a thaw and the temperature was oscillating between $-2^{\circ} \mathrm{C}$ and $-4^{\circ} \mathrm{C}$. But on the first eighteen marches from Moscow in the direction of Vjaz'ma, the enemy was already brought by hunger to a such an exhaustion that even had the cold not caught up with him, he still would not have been able to reach Orša without huge losses, especially as he was subjected to attacks first by our light troops and afterwards near Vjaz'ma and Krasnyj by the entire corps. Therefore, not frost but food shortage was the foremost reason for the destruction of the main enemy army that took place between Moscow and Orša. which was completed by defeats and the cold weather.'

In his study of the Russian system of landscape images based on the analysis of 3700 poems by 130 Russian poets, Mikhail Épštein explores the representation of winter in Russian poetry in the nineteenth and the sentieth 
centuries (Ėpštein 1990, 169-181). He finds that the image of winter, which is three times as frequent in poetry as that of summer, displays a unique amalgamation of dimensions. Russian characteristics such as mechtatel 'nost' 'disposition towards reverie', zadumčivost' 'pensiveness' and otrešennost' 'aloofness' manifest themselves in the Russian love of winter. In the nineteenth century winter was celebrated for its radiance and light. In wintertime one can discover inside a gushing source of energy that dries up in the warmer seasons. Humans and the elements coexist in a symbiosis, where they depend on each other but each follow their own laws. Because of blizzard and frost, one feels more distinctly one's blood seethe and one's heart beat, but nature remains beyond control, mysterious and independent of humans. The twentieth century, and especially A. A. Blok's poetry, emphasizes the blizzard and creates a new vortical image of Russia.

Thus, it becomes clear that on winter insiders and outsiders are at variance. This is the kind of difference of opinion that seems to have been captured by the Russian proverb Cto nemcu smert', russkomu ničego 'What is deadly to a German is fine with a Russian', insightfully quoted in REB 1938, 72 by its German authors. ${ }^{32}$

The analysis of the temporal dimension of valuable wholes makes it clear that the Proselytizing and the Broad Common-Ground Models embrace different approaches to its presentation. The former prefers to present the temporal whole whereas the latter limits itself to the presentation of its summarizing symbols. Naturally, the summarizing symbols are present in proselytizing accounts too. but there they are accompanied by concepts of a lesser rank. The Proselytizing Model insists on telling us the whole story or as much of it as space and SLL requirements allow. The Broad Common-Ground Model declares itself satisfied if it has moved the readers. touched them emotionally with the most powerful means at its disposal: summarizing symbols.

\footnotetext{
3 In another wording the proverb is also cited in RSC 1940. 54.
} 
Let us now move to the spatial dimension of the valuable whole. Here is a typical quotation that shows the general awareness of Russians that one cannot thrive outside one's homeland:

(179) Cužezemnoe rastenie. C'to sdelalos' s toboju nyne? O milyj kust! Ty bleden stal; gde zelen', zapax tvoj? - Uvy! on otvečal: ja na čužbine. (RX 1880, 51: 1. I. Dmitriev)

'Plant from afar. What happened to you today? O dear shrub! You are pale. Where is your verdure, your fragrance? "Alas!" he answered. "I am astray."

The cult of the relevant territory, which for most modern discourses coincides with the Russian state at the time of speaking, has produced over time a long series of textbook passages (such as SRJa 1870, 9-13; KC 1888, 19, 73; RS III 1898, 100-102; RM 1901, 91; RM 1904, 183-184; LR 1960, 105; URJa 1969 1:312-313; RST 1985, 55; SLR 1993, 346) that seem to have more in common across discourse boundaries than one would expect. Textbooks of the CrossCultural Comparative Model also contribute to the genre (for instance, REB 1938, 41-43).

The vocabulary that refers to the relevant territory can be divided into two categories: absolute and relational terms. The former designate the relevant territory on the basis of its intrinsic properties, the latter in its relation to Self. The Russian absolute terms for a territorial unit are strana 'country', gosudarstvo 'state', deržava 'world power' and kraj 'land', conceptually analysed by Aleksej Judin, who concludes that strana is the most universal and versatile of these terms. Kraj evokes emotion and warmth. very much like kinship, whereas gosudarstvo has a formal ring to it and reminds of one's obligations to the state. The derivation of gosudarstvo from gosudar' 'sovereign' and its usage of the Russian empire has consolidated its association first with the monarchy and later with strong authoritarian power (Judin 2003). Despite its even more emphatic links with autocracy, derżava was rehabilitated under Stalin, as one can see in (158). 
The territory relevant for Self is designated in Russian by the relational terms rodina, lit. 'native land' < rodit'sja 'to be born' and otečestvo or otčizna, lit. 'fatherland' < otec 'father'. Anna Wierzbicka formulates the difference between these words in similar terms: "rodina is, roughly speaking, a country to which one is emotionally attached, otečestvo - a country toward which one has obligations, and otčizna - a mythical country for which one yearns" (Wierzbicka 1997, 191). In her reconstruction of the early stages of Slavic on the basis of contemporary data, Svetlana Tolstaja emphasizes that the recurrence of the root rod-in terms for the homeland. the nation and the extended family indicates that nation and homeland were viewed in the light of kinship relations. There was a link of 'homeland' both to mother and father, albeit of a different nature. The figure of the father was present through the juridic concept of 'patrimony', whereas the figure of the mother was a traditional symbolic representation of the nurturing native soil worshipped by Slavs and other early agricultural societies (Tolstaja 1993).

As the following quotations testify, the relevant territory designated by an absolute or a relational term is valuable in itself for different discourses: Autocratic (180), Communist (181) and Bridging (182).

(180) My odno ljubim. odnogo žclaem: ljubim otečestvo; želaem emu blagodenstvija ešče bolee neželi slavy; želaem, da ne izmenitsja nikogda tverdoe osnovanie našego veličija; da pravila mudrago samoderžavija i svjatoj very bolee $\mathrm{i}$ bolee ukrepljajut sojuz častcj; da cvetet Rossija po krajnej mere dolgo, - esli na zemle net ničego bcssmertnago, krome duši čelovečeskoj. (RX 1894, 112)

'We love just one thing and have one wish: we love the fatherland [otecestvo] and wish it prosperity even more than glory. We wish that the solid base of our grandeur never alters, that the rules of wise autocracy and holy faith consolidate more and more the union of the parts, that Russia flourishes at least for a very long time if [not forever, as] nothing is immortal but the human soul.'

(181) Zabota u nas prostaja/Zabota naša takaja, / Žila by strana rodnaja, / 1 netu drugix zabot (URJa 1969, 1:204-205) 
'We have a simple concem. This is our concern. We would like to make sure that our native country [strana rodnaja] lives on and we have no other concerns.'

(182) 22 ijunja 1941 goda Germanija napala na SSSR. Načalas' Velikaja Otečestvennaja vojna. Velikaja, potomu čto togda ne bylo sem'i, kotoraja ne poslala by na vojnu s nemcami muža, brata, otca. Velikaja, iz-za togo ¿to milliony lučšix synovej $\mathrm{i}$ dočerej našego naroda pogibli $\mathrm{v}$ bor'be protiv nemcev. Otečestvennaja, tak kak ves' narod zaščišcal zemlju svoix otcov, svoju Rodinu. (RREG 1992, 189)

'On June 22, 1941 Germany attacked the USSR. The Great Patriotic War began; Great because there was then no family that did not send to war with the Germans a husband, a brother or a father; Great because millions of the best sons and daughters of our nation gave their lives in the struggle with the Germans; Patriotic [lit. 'Fatherland's'] because the entire nation defended the land of its ancestors [lit. 'fathers'], its homeland [rodina].'

Seen from a semiotic perspective, not only the similar assessments but also the repetitiveness of characteristics across discourses becomes explicable. All insider parties are proud of the size of Russia and the variety of its nature:

(183) Rossijskaja imperija est' samaja obšimejšaja v mire. (SRJa I869, 38)

'The Russian Empire is the largest in the world.'

(184) Zemlja russkaja, otečestvo naše, obక̌imee i slavnee drugix zemel'. Gordis' tem i veličajsja, čto rodilsja ty russkim... Carstvo russkoe veliko: ot Finskago morja do Cemago budet sliškom tysjaca pjat'sot verst, ot Belago morja do Kaspijskago bez malago dve tysjači pjat'sot verst; a v dlinu, ot Pol'ši do samago konca Sibiri, budet bol'se dvenadcati tysjač verst. (KC 1888,19$)$

'The Russian land, our fatherland, is larger and more glorious than other lands. Take pride and honour that you were born Russian. ${ }^{33} \ldots$. The Russian tsardom is great: from the Finnish to the Black Sea there are more than fifteen hundred versts, from the White to the Caspian Sea nearly twenty-five hundred versts and at length from Poland to the end of Siberia there are more than twelve thousand versts.'

(185) Ploščad' S.S.S.R. sostavljajet odnu క̌stuju vsego zemnogo šara. 'The surface of the USSR constitutes one sixth part of the entire globe ' (NRG 1935, 156; English translation as in the original)

\footnotetext{
${ }^{33}$ The audience of this textbook is Latvian youth.
} 
(186) On [poezd "Rossija"] projdet čerez vsju stranu s zapada na vostok. Tol'ko $k$ koncu sed'myx sutok pridet on vo Vladivostok. "Moskovskoe vremja desjat' časov" - uslyšat passažiry po radio, a zdes' budet uže tri časa dnja. Sem' casovyx pojasov peresečet poezd "Rossija", 87 raz ostanovitsja on na bol'šix i malen'kix stancijax. Raznye poezda ezdjat po dorogam Sovetskogo Sojuza, no takoj odin. Ego put' ot Moskvy do Vladivostoka, vostočnoj granicy Sovetskogo Sojuza, - 9297 kilometrov. (RST 1985, 248)

'It [the train Russia] will cross the entire country from west to east. Only at the end of the seventh 24-hour period will it arrive in Vladivostok. The passengers will hear on the radio "Moscow time ten o"clock" and here it will be three o'clock p.m. The train Russia will pass through seven time zones; it will stop eighty-seven times on big and small stations. There are various trains that travel along the roads of the Soviet Union but this one is unique. Its route from Moscow to Vladivostok at the eastern border of the Soviet Union is $9,297 \mathrm{~km}$ long.'

Cultural and ethnic diversity fills the endless spaces. Insider cultural mediators take great pride in the multiculturalism of Russian society, as is obvious from illustrations (e.g., CR 1948. passim; RS III 1898, 101, 106.110: the inhabitants of Russia in folk costumes) and narratives:

(187) Krome russkix, mnogočislennejšago i gospodstvujuščago naroda $v$ Imperii, $v$ našem obšimom gosudarstve živet nebol’šoe čislo inoplemennikov, sootečestvennikov našix, govorjaščix raznymi jazykami. Jazykov svoix sootečestvennikov vsex ne uznaeš', xot' učis' celuju žizn'! (SRJa 1870, 12)

'Besides Russians, the most numerous and prevalent people (narod) in the Empire, there are in our vast state some number of other ethnic groups. our compatriots. speaking in various languages. You couldn't leam all the languages of your compatriots even if you would study them all your life.'

(188) Odnaždy Biron predložil imperatrice Anne loannovne ženit' odnogo iz pridvornyx šutov. [...] Gosudarynja ob"javila [...] svoc želanie, čtob èto toržestvo soveršilos' $v$ ledjanom dome. [...] Svadebnyj maskerad, ustroennyj po planu Volynskago, byl počti takže neobyknovenen, kak i samyj dom. [...] Iz vsex oblastej Rossii, naselennoj množestvom različnyx narodov, vypisano bylo po parc iz každago plemeni. Vse oni javilis' na ėtot maskerad $v$ bogatyx odeżdax svoego plemeni, sdelannyx na sčet kazny, vse oni pljasali po rodnoj muzyke. i daže za obedom vsem im podali to bljudo, kotoroe oni predpoctitel'no ljubili na rodine. [...] Za nimi [sc. molodyni] popamo $v$ sanjax exali gosti. No ne podumajte, čtob vse èti sani zaprjaženy byli 
lošad'mi. Net! One zaprjaženy byli raznymi životnymi i po bol'šej časti temi, na kotoryx ezdili $v$ toj strane, otkuda byla priezžaja ceta. I tak vprjaženy byli $v$ sani i oleni, i sobaki, i byki, i daže kozly i medvedi! (RX 1880, 181-182)

'Once Biron [S. I. Bühren] suggested to Empress Anna Ioannovna to marry off one of the court jesters. [...] Her Majesty expressed [...] a desire that the ceremony take place in a house made of ice. [...] The wedding masquerade organized by [A. P.] Volynskij was almost as bizarre as the house itself. [...] [Guests] from all Russian provinces inhabited with many different ethnic groups (narody) were invited, a couple from each group. All of them came to the masquerade in the rich folk costumes of their group. The outfits were made at treasury's expense. All guests were dancing to their native music and even at dinner they were served the dish that they favoured in their home region (rodina). [...] They [the newly wed] were followed by the guests, each couple in its own sleigh. But you shouldn't think that horses were hamessed to the sleighs. No! Various animals were hamessed, mostly the draft animals employed in the respective area where the couple came from. So the sleighs were drawn by reindeer and dogs and bulls and he-goats and even bears!'

(189) Načinaetsja toržestvennyj marš. Na ploščadi pojavljaetsja pervaja kolonna sportsmenov. Vperedi gigantskij gosudarstvennyj flag SSSR, potom gosudarstvennye flagi vsex respublik Sovetskogo Sojuza. Nad golovami sportsmenov ogromnyj maket ordena "Pobeda". Vse 16 respublik prislali svoi delegacii. Každuju iz nix možno uznat' po krasivym nacional'nym kostjumam. V šelkovyx vyšityx odeždax idut russkie, za nimi ukraincy i belorussy. Vysokie, strojnye, proxodjat gruziny, armjane i drugie predstaviteli narodov Kavkaza. Po zagorelym licam i bogatym vostočnym odeždam gosti uznajut uzbekov, turkmen, tadžikov. (RMLR 1947, 217-219)

'The solemn march begins. The first column of athletes appears in the square. At the head there is a giant flag of the USSR; the state flags of the Soviet republics follow suit. Above the heads of the athletes glides a huge model of the order Victory. All sixteen republics have sent their delegations. One can recognize each of them by their beautiful folk costumes. Russians are walking in silk embroidered clothes, followed by Ukrainians and Belorussians. Tall and slender, Georgians, Armenians and the other representatives of the Caucasus are passing by. The audience can distinguish the Uzbeks, Turkmens and Tajiks by their suntanned faces and rich Asian garments.'

(190) Nam kažetsja važnym dobavit' ešče odnu osobennost', s kotoroj vy možete vstretit'sja $v$ Rossii. Po tradicii inostrancy vsex graždan Rossii nazyvajut russkimi. No èto daleko ne vsegda tak; Rossija - strana mnogonacional'naja, a vot vnešne èto vyraženo ne vsegda. Poètomu vam mogut otvetit' (inogda daže s obidoj!) - ja ukrainec, ja belorus, xotja i živu v 
Rossii; ja baškir, ja tatarin i t. p. Vy možete uslyšat' i raznuju reč': v Moskve govorjat tak, a na severe - inace. (MPMR 1998, 8)

'We think it is important to mention another peculiarity that you may encounter in Russia. Traditionally foreigners call Russians all citizens of Russia. But that is far from being always the case. Russia is a multinational country but outwardly this is not always manifested. That is why one can hear in response (and sometimes even with resentment!): I am Ukrainian, I am Belorussian although I live in Russia: I am Bashkir, I am Tatar and so on. You can also hear different speech: in Moscow people speak in one way, in the North in another way.'

Despite diversity, space is seen as rigorously structured in centre (Moscow and/or St. Petersburg) and periphery. It is the centre of the relevant territory that serves as a metonymical summarizing symbol of the whole. A linguistic argument for the symbolic equation 'capital city = country' are the examples of city names (in their English versions) that have become the name of the corresponding country: Rome 'name of the Roman empire' < 'name of a city in Latium', Byzantium 'name of the Byzantine empire' < 'ancient name of Constantinople', Muscovy 'name of the Russian state from c. 1300 to c. $1700^{\prime}<$ 'name of its central city, Moscow'. A series of reading passages in the secondlanguage textbooks introduce this summarizing symbol to the readership. Moscow (KC 1888, 89-90; RAPP 1898, 31; RESW 1933, 168, 180-181; DKNJR 1938. 41-44; MPLR 1952. 141-142: URJa 1969. 1:79-81; RJaSI 1970, 231-232; RJaV 1976, 348-349; RST 1985, 261-264, 316; SLR 1993, 178, 279, 345; DDP 1995. 1:43-46; RJaV 1995, 87-89, 117, 125-126; NIR 2000, 50-51) comes up more frequently than St. Petershurg (REB 1923, 46.47: DKNJR 1938, 196-198; RMLR 1947, 293-296; RST 1985, 284; V 2 1991, 109-118; DDP 1995, 5:25-26; RB 1999, 335-336). Here are some typical presentations:

(191) "Moskva est" tretij Rim", govorjat sii povestvovateli, a cetvertago ne budet. Kapitolij založen na meste, gde najdena okrovavlennaja golova ¿elovečeskaja; Moskva takže na krovi osnovana $i k$ izumleniju vragov našix sdelalas' carstvom znamenitym. (SRJa 1869, 110) 
"Moscow is the third Rome," these narrators say, and there will be no fourth. The Capitol was founded in the place where a human head covered with blood was found. Moscow too was founded on blood and became a famous tsardom to the constemation of our enemies.'

(192) Kto ne znaet Moskvy? U kogo iz russkix ne ležit serdce k Belokamennoj? Vse my nazyvaem ee matuškoj-Moskvoj. Bol'še semi sot let prošlo s togo vremeni, kak ee postroili, i s tex por ona vse rosla i raš̌irjalas. Dlja togo, čtoby ob"ezdit' v nastojaščee vremja Moskvu s eja mnogočislennymi ulicami i pereulkami, nužno neskol'ko dnej. V Moskve mnogo drevnix cerkvej; v nekotoryx iz eja starinnyx xramov rastut daže derev'ja. Glavnaja svjatynja Moskvy - Kreml'; v ego stenax xranitsja vse dorogoe russkomu serdcu. (RAPP 1898, 31)

'Who doesn't know Moscow? What Russian has no liking for the city made of white stone? We all call it Mother Moscow. More than seven hundred years have passed since it was built and it has grown and expanded ever since. One needs now several days in order to ride all over Moscow with its many streets and lanes. There are many ancient churches in Moscow. Even trees grow in some of its old temples. The main sacred treasure of Moscow is the Kremlin. Everything that is dear to the Russian heart is kept in its walls.'

(193) Moskva - stolica SSSR. Ėto bol’šoj kul’turnyj gorod. On stoit na Moskva-reke. Obščij vid Moskvy očen' krasiv. V centre goroda naxoditsja Kreml' - starinnaja krepost'. Kremlevskie steny i bašni predstavljajut interesnyj pamjatnik arxitektury. Rjadom - Krasnaja ploščad', gde vozvyšaetsja mavzolej Lenina. Krasnaja ploščad' - to mesto, gde proisxodjat voennye parady i narodnye demonstracii. Moskva - rezidencija pravitel'stva SSSR. Zdes' naxodjatsja vysšie gosudarstvennye i partijnye organy. Moskva - centr nauki i iskusstva. Zdes' lučšie teatry, muzei, biblioteki, instituty. Zdes' starinnyj universitet i Akademija nauk. Različnye zdanija - gostinicy, vokzaly, a takže pamjatniki, mosty, sady i skvery - ukrašajut gorod. Naselenie Moskvy ljubit parki kul'tury i otdyxa. V Moskve zamečatel'noe metro. Stancii metro - krasivye i svetlye. "Moskva! Kak mnogo v ètom zvuke / Dlja serdca russkogo slilos"” (Puškin). (RTRL 1945, 142)

'Moscow is the capital of the USSR. It is a great city and a cultural centre. It is situated on the Moscow River. The panoramic view of Moscow is very beautiful. The Kremlin, an old fortess, is situated in the centre of Moscow. The Kremlin walls and towers are an interesting monument of architecture. The Red Square, where Lenin's Mausoleum rises, is by the Kremlin. The Red Square is the location where military parades and popular demonstrations take place. The government of the USSR is headquartered in Mosciow. The supreme government and party bodies are located here. Moscow is a centre of 
science and art. The best theatres, museums, libraries and academic institutes are here. An old university and the Academy of Sciences are also here. Various buildings - hotels and railroad stations - as well as monuments, bridges, parks and public gardens adom the city. Moscow residents love the parks for entertainment and relaxation. In Moscow there is a remarkable subway. The subway stations are beautiful and bright. "Moscow! A great deal is evoked by this sound in the heart of a Russian" (Puškin).'

(194) Esli vy poprosite svoego moskovskogo znakomogo pokazat' samuju "moskovskuju" čast' goroda, to možete byt' uvereny, čto on povedet vas na Arbat. Dlja moskviča bez Arbata Moskva ne Moskva. Dlja nego èto ne tol'ko nazvanie odnoj iz moskovskix ulic, no èto $i$ ležaščie rjadom $s$ nim mnogocislennye pereulki [...] Ėto čast' raspoložennogo nedaleko ot Kremlja rajona Moskvy, v kotorom poctti każdyj dom sama istorija. (RST 1985, 267268)

'If you ask a Moscow acquaintance to show you the neighbourhood most representative of Moscow, you can rest assured that he [or she] will take you to Arbat. To a Muscovite. Moscow would not be Moscow without Arbat. For him [or her] this is the name not only of one of the Moscow streets but also of the numerous adjacent lanes. $[\ldots]$ This is a pan of the city situated near the Kremlin, where almost every building is history itself.'

(195) Ja xotel by žit'i umeret' v Pariže. / Esli b ne bylo takoj zemli - Moskva. (ČRR 1997, 83: Vladimir Majakovskij, Prošćanie 'Farewell' [1925])

"I would have liked to live and die in Paris, if there were no such place like Moscow.'

There are also comparisons of the two capital cities of Russia, which since the beginning of the eighteenth century have vied for the hearts of Russians (RS III 1898, 102-105; RST 1985, 258-259). The importance of the centre as a summarizing symbol of the whole, however, goes beyond such stories in Russian second-language textbooks. Everything that happens in these textbooks is usually presented from the vantage point of this symbolic centre, as for instance in this typical dialogue with a Muscovite who has moved to the Siberian centre for academic research (Akademgorodok):

(i96) - Kak vy, Aleksandr Petrovič, ne skučaete tam? Vy ved' moskvič?

- Net. U nas est' teatr, xorošaja bibioteka, kafe... I v Akademgorodke živut očen' interesnye ljudi. (RJaV 1976, 103) 
"“So, Aleksandr Petrovič, don't you find it boring to live there? You are after all a Muscovite, aren't you?"

"No [it is not boring]. We have a theatre, a good library, a café... And besides, fascinating people live in the Akademgorodok."

Provincial Russia and the non-Russian regions and republics of the USSR have always had their place of honour in Russian second-language textbooks but as concepts of lower rank. This state of affairs agrees with the conspicuous absence of terms for the inhabitants of specific regions like the exceptional sibirjak 'inhabitant of Siberia', an absence noticed by Roman Lewicki (1993). Not coincidentally, it is in REW 2000, the textbook whose author Gulnara Useinova is a non-Russian insider, that we hear the periphery at last say its word. I shall use only one example to support my argument. The author systematically uses bazar 'marketplace', as in (197) and (198), and supplies her usage with the metalinguistic remark "they say bazar in southern Russia, rynok in northern Russia" (REW 2000, 63).

(197) Ėto magazin. V magazine mjaso, kurica, ryba, ikra. Ėto bazar (rynok). Na bazare luk, kartoška, pomidor, kapusta, jabloko, gruša, apel'sin. (REW 2000. 63).

'This is a store. There is meat, chicken, fish and caviar in the store. This is a market. There are onions, potatoes, tomato[es], cabbage, apple[s], pear[s] and orange[s] in the market.'

(198) V kabinete na stene u nas est' staryj kover. Emu tože 50 let. Moja babuška kupila ego na bazare $v$ Taškente. (Taškent - èto gorod $v$ Uzbekistane.) (REW 2000, 85)

'On the wall in our study there is an old rug. It too is fifty years old. My grandmother bought it in the market in Tashkent. (Tashkent is a city in Uzbekistan.)'

The two regional synonyms are given equal right but the preference of the author is for the provincial bazar. Many speakers of the Moscow variety of Russian feel that there is a difference between these synonymous terins even when they are used to denote the marketplace (see < www.spravka.gramuta.ru>, 
answer to question \# 39962). Rynok is a much broader term, as it is the only one used of the market economy. Besides, their connotations are completely different, which makes possible their juxtaposition as in the following newspaper title from the Internet:

(199) Šli na rynok, a popali na bazar ili èkskljuzivnaja privatizacija pokazaxstanski

'We were going to the marketplace but we ended up at an Oriental bazaar or exclusive privatization Kazakhstan style'

REW 2000 illustrates the contemporary tendency towards emancipation of the periphery through the promotion of regional identities claiming equal status with the centralized common identity, which was the norm until recently. It is too early to judge how successful this tendency will be.

The preference for the summarizing symbols of the relevant territory over the descriptions of this territory, a preference that can easily be proven by the numerical strength of the descriptions of the centre(s) in comparison of those of the whole, fits statistical data: 41 per cent of respondents associated narod (to be discussed as a valuable whole in its own right in the next section) with their own place of birth and only 25 per cent with the entire country (Levada 1995, 223). In other words, people tend to reach for the summarizing symbol of the whole rather than the whole itself. Given the fact that most textbook authors are residents of either Moscow or St. Petersburg, it becomes clear that they have more than one reason for their choice. These numbers can perhaps also throw light on the predominance of the Broad Common-Ground textbooks (whose staple is summarizing symbols) over the Proselytizing textbooks. Given a chance, most people are sensitive to Grice's quantity maxim “Make your contribution sufficiently informative for the current purposes of the conversation. Do not make your contribution more informative than is necessary" and would not assume the didactic stance, which is unavoidable if one starts to describe valuable wholes to one's audience. As there is no reason to believe the rate of dopes to be 
greater among second-language textbook authors than among the general population, one should expect the Broad Common-Ground textbooks to be the norm and search for an explanation for alternative choices, rather than treat the Proselytizing and the Broad Common-Ground Models as equally probable.

The birch tree is a metaphorical summarizing symbol that can stand for Russia as the territory relevant to Self. As a nostalgic symbol of Russia for those who are away, it first appears in prose in Puškin's correspondence (1824) and in verse in a poem by $\mathrm{P}$. A. Vjazemskij (1855?) to become later a recurring motif in the poetry of such different poets as A. A. Fet, K. D. Bal'mont, V. Majakovskij, S. A. Esenin, S. P. Sčipačev, A. A. Prokof'ev, V. N. Sokolov and A. A. Voznesenskij (Ėpštein 1990, 57-62). Actually it is the tree most frequently evoked in Russian poetry. Mikhail Ėpstein concludes that the image of the birch in Russian poetry is polysemantic. The birch's whitish bark and drooping branches make it the epitome of sadness but sadness luminous, not gloomy. Its role in the pre-Christian spring fertility rituals adds exultant gaiety to its palette and a connection to femininity.

Birches show up now and again in Russian second-language textbooks, especially in poems (ŽS 1926, 95; DKNJR 1938, 190; PFK 1995, 46; RB 1999, 245), passages of lyrical prose (RU 1902, 167; CRR 1997, 24) or illustrations (as in RJaV 1995, 249 and on the paintings by K. F. Juon The End of Winter and I. I. Levitan Golden Autumn at the end of RJaSI 1970). Sometimes birches are even the topic of conversation between characters:

(200) Anton: - A u tebja est' ljubimye derev`ja?

Maša: - Bol’łe vsego ljublju berezki. Ne starye, vysokie, a molodye - oni takie trogatel'nye, nežnye, narjadnye, strojnye. Ja $k$ nim podxožu i sprašivaju: ..Kak poživaete?‘. I kažetsja, čto oni mne otvečajut.

Anton: - Dejstvitel'no, oni krasivye.

Maša: - Ėto ešce čto! Ty by posmotrel na nix vesnoj, kogda pojavljajutsja posle zimy pervye listocki. Takoj aromat - prosto blagodat'. Vesnoj berezki plačut. Možno podstavit' kružku i nabrat' berzzovye sleż - sok. (RJaV I995, 252-253)

'Anton: And do you have favourite trees? 
Maša: I love birches best of all. Not old and tall but young. They are so touching. delicate, trim and slender. I go near them and ask: "How is life?" And it seems as if they respond.

Anton: They indeed are beautiful.

Maša: That is not everything. If you could see them in spring when the first leaves appear. What fragrance! It is simply heavenly. In spring the birches weep. One can put a mug under and fill it with birch sap - the birch's tears.'

In contrast with the Russia/USSR-based discourses, the early Communist discourse sees the Soviet Union and its capital Moscow in a different light, as illustrated in the text entitled SSSR-udamaja brigada proletariata vsex stran 'USSR - the Shock Brigade of International Proletariat':

(201) V Anglii i Amerike buržuazija - gospodstvujuščij klass. Ona zaxvatila vse bogatstva. vse orudija $i$ sredstva proizvodstva. Ona èkspluatiruet proletariat $i$ vse trudjaščeesja naselenie. Ona poraboščaet $i$ grabit narody kolonij i polukolonij. Buržuazija vsego mira - vrag Sovetskogo Sojuza. V SSSR net pomeščikov i kapitalistov, v SSSR - vlast' sovetov. V SSSR diktatura proletariata. Proletariat - avangard vsego trudjaščegosja naselenija SSSR. VKP (b) - avangard proletariata. Pod rukovodstvom partii proletariat i vse trudjaščiesja strojat novoe obščestvo - besklassovoe socialističeskoe obščestvo. Socializm - pervaja stadija kommunizma. Konečnaja cel' proletariata - postroenie kommunističeskogo obščestva. Proletarii vsex stran i ugnetennye narody Vostoka - druz'ja i sojuzniki proletariata SSSR. Sovetskij Sojuz - udamaja brigada proletariata vsex stran. Kapitalizm obrečen na gibel'. Grandioznoe socialističeskoe stroitel'stvo SSSR, približaet gibel' kapitalizma - uničtoženie neravenstva i èkspluatacii vo vsem mire. Vse na zaščitu SSSR! (RESW 1933, 162-163)

'In England and America, the bourgeoisie is the ruling class. It has seized all wealth, all implements and means of production. It exploits the proletariat and all the toiling people. It enslaves and loots the nations living in colonies and semicolonies. The world bourgeoisie is the enemy of the Suviet Union. In the USSR there are no landlords and capitalists; in the USSR there is Soviet power. In the USSR there is dictatorship of the proletariat. The proletariat is the vanguard of the entire toiling population of the USSR. The All-Union Communist Party (Bolsheviks) is the vanguard of the proletariat. Under party guidance the proletariat and all toiling people are building a new society: the classless socialist society. Socialism is the first stage of communism. The final goal of the proletariat is to build a communist society. The proletariat in all countries and the oppressed Oriental nations are friends and allies of the proletariat in the USSR. The USSR is the shock brigade of the international 
proletariat. Capitalism is doomed to ruin. The immense socialist construction in the USSR nears the end of capitalism, the liquidation of inequality and exploitation in the whole world. Everybody join in the defence of the USSR!'

In tune with this description, the passage about Moscow in the same textbook mentions not only the most important Soviet institutes of power situated in Moscow but also the international Communist organizations. Here is its beginning:

(202) Moskva - glavnyj centr SSSR i RSFSR. Zdes' sobiraetsja Vsesojuznyj s"ezd sovetov - vyš̌aja vlast' Sovetskogo Sojuza. V Moskve naxoditsja CIK SSSR, Sovnarkom SSSR, sojuznye i ob"edinennye narodnye komissariaty, a takže vysšie gosudarstvennye učreždenija RSFSR. V Moskve naxodjatsja: CK VKP(b), CK VLKSM, VCSPS. Moskva - mestoprebyvanie IKKI. V Moskve naxodjatsja drugie meždunarodnye proletarskie organizacii: Profintern, Ispolnitelnyj komitet MOPR. V centre goroda naxoditsja Kreml'. Okolo Kremlja - Krasnaja ploščad'. Na Krasnoj ploščadi - mavzolej Lenina. Moskva - krasnaja stolica pervogo $v$ mire proletarskogo gosudarstva. (RESW 1933, 168)

'Moscow is the main centre of the USSR and the Russian Soviet Federative Socialist Republic (RSFSR). The All-Union Congress of Soviets, the supreme authority in the Soviet Union, convenes here. The Central Executive Committee of the USSR, the Council of People's Commissars of the USSR, the union-level and the amalgamated people's commissariats, as well as the supreme government bodies of the RSFSR are in Moscow. In Moscow are situated the Central Committee of the All-Union Communist Party (Bolsheviks), the Central Committee of the Leninist Young Communist League of the Soviet Union, the All-Union Central Council of the Trade Unions. Moscow is the headquarters of the Executive Committee of the Communist International. Other international proletarian organizations are situated in Moscow: the Red International of the Trade Unions and the Executive Committee of the International Organization for Assistance to Revolutionaries. The Kremlin is in the centre of the city. Near the Kremlin is the Red Square. Lenin's Mausoleum is in the Red Square. Moscow is the red capital of the first in the world proletarian state.'

Although the relevant territory in this discourse is the globe and the Soviet Union is only "the Shock Brigade of Intermational Proletariat," its capital Moscow still preserves its importance as a summarizing symbol (capital of the proletarian world), but a metaphorical summarizing symbol like the bitith is out 
of place and it resurfaces in Communist discourse only later, at its mature synthetic stage.

The relevant group of people is defined by a combination of ethnic, linguistic, denominational and citizenship criteria, as in (203), or alternatively according to social class, as in (201):

(203) Ljudi, govorjaščie na odnom i tom že jazyke, sostavljajut odin narod. Meždu nekotorymi jazykami est' bol'šie sxodstvo. Tak, napr., russkij, poljak, serb, cex, mogut neskol'ko ponimat' drug druga. Narody, govorjaščie na stol' sxodnyx jazykax. sostavljajut odno plemja. Russkie, poljaki, serby i cexi prinadležat $k$ slavjanskomu plemeni; nemcy, švedy, angličane prinadležat $k$ germanskomu, a francuzy, ital'jancy $u$ ispancy $-k$ romanskomu plemeni. Vsjakij narod nepremenno ispoveduet kakuju-nibud' veru. Veroispovedanij. ili religij, očen' mnogo. No obyknovenno različajut tol'ko cetyre osnovnye veriospovedanija: xristianskoe, iudejskoe, magometanskoe i jazyčeskoe. (RM 1904, 176-177)

'The people who speak the same language represent one nation (narod). Between some languages there is a great similarity. For example. a Russian, a Pole, a Serb and a Czech can understand each other to some extent. Nations that speak in such similar languages form a family. Russians. Poles, Serbs and Czechs belong to the Slavic family; Germans, Swedes and Englishmen belong to the Germanic family: and Frenchmen. Italians and Spaniards to the Romance family. Each nation necessarily practises a religion. There are very many denominations or religions. Usually, however, only four basic denominations are distinguished: Christianity, Judaism. Islam and Paganism.'

The term employed to denote the relevant group of people regardless of definition is narod. The terminological unity veils the fact that the word is used with different meanings. It is possible to distinguish between four usages of narod: (1) The ethnicity-based narod, refers to a group of people who have a common ethnic origin and a common language and inhabit the same territory; typical collocations are narody Rossii 'the pcoples [ethnic groups] of Russia'. narody SSSR 'the peoples [ethnic groups] of the USSR', russkij narod 'the Russian people'. (2) The state-based narod 2 refers to a group of people who inhabit a country and share the same political institutions: a typical collocation is 
sovetskij narod 'the Soviet nation'. (3) The class-based narod 3 refers to those people who lack power, influence and wealth, who are experiencers rather than agents and are seen as a repository of mystical spiritual qualities; typical collocations are narod bezmolvstvuet 'the people are silent' (a popular phrase stemming from Puškin's Boris Godunov) and prostoj narod 'the simple folk'. (4) Narod, 'crowd' refers to a group of people, usually a large group, in the immediate presence of the speaker. It is a colloquial synonym of ljudi 'people'. Only narod 1 and narod 2 are explicitly connected with a territory and their spatial counterparts are kraj (relational rodina) and gosudarstvo (relational otečestvo), respectively. Any of the meanings of narod except the fourth can be associated with an identity discourse. Narod, taken on its own describes the valuable whole of people only for the Patriotic discourse. It is, however, part of the mix for such discourses as the Autocratic, the Slavophile and the Bridging one. Narod 2 has been the focus of all consecutive orthodox discourses: the Autocratic, the Communist and the Bridging. Narod $_{3}$ used to be the valuable whole of the Revolutionary discourse and continued to be relevant to Communists after they came to power. According to the Communist discourse, it is narod 3 or its typical representatives that pronounce such utterances:

(204) Prežde i teper'. Otec otdal menja k kulaku $v$ batraki. Mne togda bylo 13 let. Rabotal ja u kulaka s utra do noči. Prožil ja u nego pjat' let. Teper' ja živu $v$ kolxoze polnopravnym členom. U nas $v$ kolxoze zemlja obščaja, rabotaem mašinami. Est' u nas traktor. My ustroili obščuju stolovuju, klub. V klube est' kino, radio. (MLR 1938, 1:51)

'Before and now. Father hired me out to a kulak ['rich peasant'] as a farm labourer. I was then thirteen years old. I was working for the kulak from dawn to dusk. I lived at his farm for five years. Now I am a full-fledged member of the collective farm. The land on the farm is everybody's property. We are working with machines. We have a tractor too. We organized a canteen for general use and a club. In the club there is a movie theatre and a radio.'

(205) Ran'še žili - slezy lili. Teper' živěm - sčast'e kuem. (RJa 1952, 531 
'Our life was such that it used to provoke bitter tears. Now we are the masters of our own happiness.'

(206) Zhivi ne tuži - teper' net meži. (RJa 1952, 53)

'Enjoy your life: there are no hedges [between fields] any more.'

Today, the heterodox Communist discourse continues to prize this group. Narod $_{3}$ also participates in the Slavophile, as in (207), and, to some extent, the Bridging mix.

(207) Ja ljublju prostoj russkij narod. Ne znaju počemu - on dlja menja vsegda okružen obajaniem čego-to osobennogo, tixogo, trogatel'nogo, nemnogo pečal'nogo, kak ta priroda, sredi kotoroj on živet. Ja ljubil ego vsegda, ešče s detstva, no zdes' ja poljubil ego ešče bol'še. Nigde ja ne vidal sredi krest'jan takogo značitel'nogo procenta čestnyx, vsegda trezvyx i gluboko simpatičnyx ljudej, kak zdes', $v$ novgorodskoj gluši. Vmeste $s$ tem èto pročnyj, dolgovečnyj i krepkij narod. Kakoj-nibud' djadja Paxom živet, živet na svete $i$, nakonec, načinaet kazat'sja čem-to tainstvennym, stixijnym, čego i smert' ne beret. (DKNJR 1938. 187: Sergej Meč)

'I love the simple Russian folk. I don't know why. They have always been surrounded for me with the charm of something special, quiet and touching. a little sad like the nature in the midst of which they live. I have always loved them, ever since childhood, but here I started loving them even more. I have never encountered among peasants such a significant number of honest, always sober and deeply likeable people as here in the remote Novgorod area. At the same time these are strong. long-living and sturdy people (narod). One can encounter the likes of grandfather Paxom, who has lived for so long that he has acquired a mysterious and elemental aura that makes one believe that even death has no power over him.'

In other words, when different people say narod, they mean different things but they all love it. The data collected by a sociological survey carried out in 1994 can prove that the valuable wholes of people, events and territory are indeed linked. Moreover, space is perceived as being more important to narod than time, so much so that they can be denoted by the same word, as I mentioned above when I was discussing the early term Rus', which refers in one breath to the territory and the people that inhabit it. Another example is mir "world the 
globe with its inhabitants)', which since the Holy-Rus doxa has also been used to denote the community (of a village or town) or the parish.

Respondents to the survey were allowed to choose more than one answer as correct. According to $93 \%$ the first thing on their minds when they were thinking of their narod was territory, be it narrowly defined as one's birthplace $(41 \%)$ or broadly as one's country (25\%), or, alternatively, symbolically as the nature of one's country $(18 \%)$ or the dear graves and monuments of the native land (9\%). Conversely, $54 \%$ claimed that priority should be granted to the events in which one participates together with one's narod (according to $37 \%$ to history and according to $17 \%$ to songs, holidays and customs) (Levada 1995, 223). Based on the same survey we can identify $19 \%$ of respondents as adherents of narod, because they considered language as narod's association of utmost importance; $23 \%$ as adherents of narod $_{2}$ because $18 \%$ thought first of the state, whose citizens they were, and 5\% of this state's military might; and, finally, $30 \%$ as adherents of narod 3 because $16 \%$ of them associated the term in their minds with narod's spiritual qualities, $8 \%$ with religion and $6 \%$ with stereotypical features of national character such as industriousness.

The following quotations testify to the positive evaluation of narod in varying discourses, whether they happen to mention the word, as in (148), (175), (209), (210), (211), (217) and (247) or not, as in (208):

(208) Tjažko vzdyxali okrestnosti, i zemlja, kazalos' Łatalas' pod bremenem sražajuščxsja: francuzy metalis's dikim osterveneniem; russkie stojali s nepodvižnostiju tverdejšix sten. Odni stremilis' dorvat'sja do voždelennago konca vsem Irudam i dal'nym poxodam, zagresti sokrovišca, im obešcannyja. i nasladit’sja vsemi utexami žizni $v$ drevnej, znamenitoj stolice; drugie pomnili, cto zaslonjajut soboju siju samuju stolicu, serdce Rossii, mat' gorodov. Oskorblennaja vera, razorennyja oblasti, porugannye altary i praxi otcov, obižennye $v$ mogilax, gromko vopijali o pomošči i mužestve. Serdca russkija vnimali svjašecnnoomu voplju semu: mužestvo našix vojsk bylo neopisanno. (RX 1894, 108-109)

'The surroundings were breathing heavily and it scemed that the ground was swaying under the fighting: the French were rushing about in a wild frenzy; the Russians were standing with the immobility of the firmest widls. The 
former were striving to reach the desired end of all efforts and long marches. rake in the treasures promised to them and revel in all the pleasures of life in the ancient renowned capital; the latter remembered that they were shielding with their bodies this same capital, the hear of Russia, the mother of all cities. The hur faith, the ravaged provinces, the desecrated altars and the ashes of the ancestors insulted in their graves were wailing loudly about relief and courage. The Russian hearts were attending to this cry. The courage of our troops was indescribable.'

(209) Rabočij klass - samyj peredovoj klass. Rabocij klass vedet trudovoj narod. Trudovoj narod stroit socializm. (MPLR 1952,39)

'The working class is the most advanced class. The working class leads the toiling people. The toiling people are building socialism.'

(210) 'Esli ty $v$ samom sebe ne naxodiš' motivov dlja radosti, - pisal $v$ odnom pis'me Cajkovskij, - smotri na drugix ljudej. Stupaj v narod! Smotri kak on umeet veselit'sja..." (RMLR 1947, 288-290)

"'If you cannot find in yourself motives for joy," Cajkovskij wrote in a letter, "look at the other people. Go to the simple folk! Look how much fun they have..."

(211) Zdes's detskix let on [L. Tolstoj] videl, kak żivet prostoj narod, i ego samoj junoj ljubov'ju stal russkij mužik. (ČRR 1997, 57)

'Here L. Tolstoj watched from childhood how the simple folk were living and his first love became the Russian peasant.'

Outsiders are acutely aware of the immense value attached to narod by insiders, as a contemporary American anthropologist testifies:

There was a certain Russian word, which I could bring myself to pronounce only with difficulty in my conversations with friends and informants. This was odd, as the word was one of the most common in Russian talk, a key word, important and useful. But I always felt sheepish trying to use this word: it was like borrowing someone else's slang, or, more accurately, like saying somcone else's prayer. The word was narod: people. populace, folk. (Ries 1997, 27)

I et us see how Russian second-language textbooks flesh out narod. All the characters in a textbook are potential members of narod. What kind of people comprise the narod of a texthook? Textbook authors have the choice between 
generic and specific members of narod, the latter being further divisible into exemplary and ordinary members. This classification parallels the classification of speaking subjects into generic, exemplary and ordinary, discussed in chapter 4. Here, however, people are viewed as agents and holders of particular qualities rather than speakers. The following examples illustrate each category across identity discourses: (212), (213), (214) and (215) generic members of narod; (216), (217) and (218) exemplary members of narod; (219), (220) and (221) ordinary members of narod:

(212) Russkij čelovek dobr, uslužliv i osobenno gostepriimen. (RX 1880, 3)

'A Russian person is goodhearted, obliging and, most importantly, hospitable.'

(213) Voobšče naš soldat otnosilsja k bolgaram pokrovitel'stvenno, daže neskol'ko svysoka, často bezžalostno nad nim posmeivajas'. Naši nesravnenno dobrudušnee bolgar, čem èti i pol'zovalis'. Za to, kogda naš zametit, čto bolgarin ego naduvaet, ètomu poslednemu ploxo prixoditsja. Obrugav ego "prokljatym židom," soldat obyčno zakatyvaet emu zatreščinu... I èto delatsja bez vsjakoj zloby, bez żelanija nanesti emu vred, a kak dolžnoe zaslužennoe. (RX 1894, 28)

'As a whole, our soldier was patronizing the Bulgarians. even looking down a bit on them, frequently mercilessly mocking at them. Our people are incomparably kinder than Bulgarians, and the latter were profiting by that. In return, when our man notices that a Bulgarian is trying to dupe him, woe to the latter. Having called him "a damned kike." the soldier usually slaps him in the face... And all this is done without any malice, without the desire to harm him, just as something he deserves.'

(214) Rabočij ne xocet nosit' staruju ploxuju rubašku i zaplatannye brjuki, kak ran'še, pri kapitalistax. On xočet imet' xorošij novyj kostjum. Rabotnıa xočet nosit' xorošie tufli. Ona xočet imet' ne odno i ne dva plat'ja. Kolxozmk i kolxoznica ne xotjat xodit' $v$ laptjax, kak xodili krest'janc pri care. Oni xotjat imet' xorošie sapogi, botinki, tufli. Rastut potrebnosti rabočix i širokix trudjašcixsja mass. Spros na promyšlennye tovary šrokogo potreblenija očen' bystro rastet $v$ SSSR. Starye fabriki i zavody ne $v$ sostojanii obsiužit' ogromnoe naselenija Sojuza. Sovetskaja strana stroit novye fabriki i favody. delaet novye mašiny. (RESW 1933, 135-136) 
'A worker does not want to wear an old low-quality shirt and patched pants as before, under the capitalists. He wants to have a nice new suit. A woman worker wants to wear nice pumps. She wants to have not just one or two dresses. A collective farmer and a collective woman farmer do not want to walk in bast sandals as under the tsar. They want to have nice boots, shoes and pumps. The needs of the workers and the broad toiling masses are growing. The demand for manufactured goods for mass consumption in the USSR is growing very quickly. The old factories and plants are incapable of serving the huge population of the Union. The Soviet country is building new factories and plants, producing new machines.'

(215) Tipičnomu žitelju Rossii okolo soroka. On starše, skažem, srednego amerikanca na 7 let i prodolžaet staret'. Vpročem, èto skoree ne "on", a "ona" - na 1000 ženščin v Rossii prixoditsja 884 mužčiny. Ee familija načinaetsja na "S". Okazalos', čto imenno s ètoj bukvy u nas $v$ strane familii načinajutsja čašce, čem s drugix. Graždanka S. zamužem. (MPMR 1998, 17)

'The typical resident of Russia is about forty years old. He is older than, let us say, the average American by seven years and continues to get older. By the way, it is not a "he" but rather a "she": there are in Russia $\mathbf{8 8 4}$ men for every thousand women. Her last name starts with "S". It turns out that sumames in our country start with this letter more often than with any other. Citizen [fem.] S. is married.'

(216) Ona [Ekaterina Vtoraja] skoro i xorošo izučila russkij jazyk, oznakomilas' s russkimi obyčajami i vseju dušoju poljubila svoe novoe otečestvo. Po smerti Petra III, kotoryj carstvoval vsego okolo polugoda, Ekaterina Il vstupila na prestol i carstvovala 34 goda (ot 1762-1796 g.) s takim iskusstvom i slavoj. čto ona, podobno Petru I. zaslužila prozvanic Velikoj. (RM 1904, 203)

'She [Catherine II] quickly and thoroughly learned Russian, got acquainted with the Russian customs and came to love her new fatherland with all her heart. After the death of Peter III, who reigned for only about half a year, Catherine II ascended to the throne and reigned thiny four years (from 1762 to 1796) with such an art and glory that she like Peter I deserved to be called "the Great".'

(217) Kazn' brata potrjasla Vladimira Il'iča i vmestc s tem zastavila ser'eznee zadumat'sja nad putjami revoljucionnoj bor'by naroda. Vladimir Il'ic otrical put' terrorističeskoj bor'by, kotoryj izbral Aleksandr. "Net, my pojdem ne takim putem, - rešil on. - Ne takim putem nado idti". Nesmotrja na ċti tjaželye ispytanija Vladimir Il’ič okončil $v 1887$ godu gimnaziju s zolotoj medal'ju. (URJa 1973, 2:204). 
'His brother's execution shook Vladimir Il'ič and at the same time made him think more seriously how the people should carry on revolutionary struggle. Vladimir Il'ič rejected the method of terrorist struggle chosen by [his brother] Aleksandr. "No, we shall choose a different path," he decided. "This is not the path that one should follow." Despite these trying ordeals, Vladimir Il'ič graduated from secondary school with a gold medal.'

(218) Kogda ja dumaju o Vysockom, vspominaju ego v teatrc, na repeticijax, na gastroljax, prosto $v$ krugu druzej, s neposredstvennoj reakciej, - ja vižu ego malen'kuju skladnuju figurku, i mne ego do spazm $v$ gorle žalko. On dejstvitel'no "ne dožil", "ne doigral", "ne dopel", dejstvitel'no ne sumel voplotit'sja polnost'ju. U nego zarjad byl na bol'see. (RJaV 1995, 355: Alla Demidova)

'When I think about Vysockij, when I recall him in the theatre, at rehearsals, at tours, simply among friends with a natural reaction, I see in front of my eyes his small well-knit figure and I feel so sorry for him that I get a spasm in my throat. He indeed "did not live long enough", "did not finish playing", "did not finish singing", he indeed did not have a chance to realize himself fully. He had a greater potential."

(219) Tureckie plenniki razrabotyvali dorogu. Oni žalovalis' na pišču im vydavaemuju. Oni nikak ne mogli privyvyknut' k Russkomu černomu xlebu. Ėto napominalo mne slova moego prijatelja $S$. po vozvraščenii ego iz Pariža. "Xudo, brat, žit' v Pariže: est' nečego; černago xleba ne doprosiš'sja!" (RX 1848, 80-93: Puškin about the Caucasus in 1829)

'The Turkish prisoners of war were working on road construction. They were complaining about the food provided for them. They could not get accustomed to the Russian dark bread. This reminded me the words of my friend S. on his return from Paris. "Life in Paris stinks, brother. There is nothing to eat. You cannot make them bring you dark bread."

(220) Noč'ju Petja uslyšal krik pod oknom. On vybežal na ulicu. Po ulice bežal narod. Za kolxoznym ptičnikom viden byl dym. Gorel korovnik. Ego podožgli kulaki. Kolxozniki bystro potušili požar. Kulakov arestovali. (MLR 1938, 1:33)

'During the night Petja heard a shout under the window. He ran out into the street. People (narod) were running along the street. Behind the collective poultry yard there was smoke. The cow shed was burning. The kulaks had set it on fire. The collective farmers quickly extinguished the fire. The kulaks were arrested.' 
(221) Mama, papa, deduška i babuška očen' ljubili svoego Vovočku. Ljubili i, konečno, ocen' zabotilis': “Vova, ne begaj! Upadeš' - budet bol'no", “Vova, ne podxodi k sobake! Ukusit!". "Vova, ne davaj svoi igruški! Ix mogut slomat". No počemu-to Vovočka vyros bezvol'nym, ègoističnym, lenivym, slabym. On vsego bojalsja, ničem ne interesovalsja. U nego ne bylo ni druzej, ni vragov. (PFK 1995, 51)

'Mum, Dad, Grandfather and Grandmother loved their Vovočka very much. They loved him and of course took good care of him: "Vova, don't run! If you fall down it will hurt." "Vova don't go near the dog! It will bite you!" "Vova don't share your toys. They can get damaged." But for some reason Vovozka grew up to be spineless, egoistic, lazy and weak. He was afraid of everything and interested in nothing. He had neither friends nor enemies.'

Naturally, characters belonging to these categories are all over the place. One can encounter them in examples cited for various purposes throughout this study: generic in (86), (108), (112), (114)-(117), (118)-(122), (129), (131), (132), (140), (147), (148), (150), (162), (168), (171), (256), (177), (187), (201) and (203); exemplary in (87), (123), (124), (126), (128), (135), (136), (141) and (156): and, finally, ordinary in (78)-(85), (90), (104)-(107). (144)-(146), (151)(153), (155), (161), (164), (170), (255), (174), (196) and (198).

Obviously, textbooks outside the Narrow Common-Ground Model (for which ordinary people are enough) can hardly limit themselves to one of these categories. What we can observe is the preference for a certain mix. One can combine in the same passage generic and exemplary members of narod. generic and ordinary members, or exemplary and ordinary members. Frequently, the story owes its point to the juxtaposition of categories. In the story entitled Bylina $o$ care Petre 'A true story about Tsar Peter' we are told how tolerant and broadminded [exemplary member] Peter I was and how he once talked to a peasant [ordinary member] without letting him know who he was. When the peasant noticed that only his interlocutor and he were keeping their hats on, he asked:

(222) "Kto že car"?" Govorit emu Petr Alekseevič "Vidno, kto-nibud' iz nas car'!" (KC 1888, 47) 
"“So who is the tsar?" Petr Alekseevic says to him: "Obviously, one of us is the tsar!"”

The same combination can be found in other discourses as well. For example, (223) features Lenin and (224) Cajkovskij, who demonstrate to an old nameless hunter and the ranger Vasilij, respectively, their love for nature:

(223) Prjamo na Lenina vybežala lisica. Ėto byla krasivaja ryžaja lisa. Osobenno xoroł byl ee ogromnyj pušistyj xvost. Lisica ostanovilas' i neskol'ko sekund stojala nepodvižno. Lenin podnjal ruž'e, čtoby vystrelit', no totčas že opustil. Lisica vil'nula xvostom i isčezla za sosnami. K Leninu bežal staryj oxotnik i kričal:

- Chto že vy ne streljali, Vladimir Il'ic? Ved' ona rjadom stojala!

Lenin ulybnulsja i otvetil:

- Ne mog vystrelit'. Už očen' ona krasivaja. Pust' živet. (RTRL 1945, 185)

'A fox was running directly at Lenin. This was a beautiful red-haired fox. Especially nice was her enormous fluffy tail. The fox stopped and stood motionless for several seconds. Lenin raised the gun in order to shoot but lowered it right away. The fox wagged her tail and disappeared behind the pine trees. An old hunter ran to Lenin shouting:

"Why didn't you shoot, Vladimir Il'ic? She was standing so close to you!"

Lenin smiled and answered:

"I could not make myself shoot. She was too beautiful. Let her live."

(224) Dolgo igral kompozitor, a kogda vyšel iz kabineta, uvidel Vasilija.

- Spasi, Petr II'ič! Pomogi! Ne daj pogibnut' lesu, - vsxlipnul lesnik. On rasskazal Cajkovskomu, čto pomeščik prodal les kupcu Troščenko, a tot prikazal rubit' les. Cajkovskij poexal k gubernatoru, čtoby ob"jasnit', ctto ètot les rubit' nel'zja. [...]

- Ja ne mogu vam pomoč'. Cuvstva i želanija artista ne vsegda sovpadajud s kommerčeskim interesom, - skazal gubernator. Cajkovskij podošel k vyxodu. On rešil poexat' k Troščnko i kupit' u nego les. (RREG 1992, 97)

'The composer played [the piano] for a long time and when he came out of his study he saw Vasilij.

"Rescue Petr Il'ič! Help! Don't let the forest perish." the ranger sobbed. He told Cajkovskij that the landowner had sold the forest to the merchant Troßcenko and the latter had ordered that the forest he felled. Cajkor'skij drove to the governor to explain to him that this forest should not be felled. [...] 
"I cannot help you. The feelings and the desires of an artist do not always coincide with commercial interest," the governor said. Cajkovskij went to the exit. He decided to go to Trošenko and buy the forest from him.'

The simplicity (prostota) of the great men who are truly great is a favourite theme in Russia; no wonder it can be encountered across discourses. What easier way to foreground it than to show these great men in interaction with some ordinary representatives of narod?

Examples (225) to (228) illustrate the juxtaposition of generic and exemplary members, whereas (229) to (232) show the mechanism of weighing an ordinary member against the standards and boundaries embodied in generic members:

(225) V lice Ivana Andreevica Krylova my videli v polnom smysle Russkago celoveka, so vsemi xorošimi kačestvami i so vsemi slabostjami, isključitel'no nam svojstvennymi. Genij ego, kak basnopisca, priznannyj ne tol'ko v Rossii, no $i$ vo vsej Evrope, ne zašcitil ego ot obyknovennyx našix nerovnostej $v$ żizni, posredi kotoryx Russkie inogda sposobny vsex udivljat' pronicatel'nost'ju $i$ vernost'ju uma svoego, a inogda predajutsja neprostitel'nomu xladnokroviju $v$ delax svoix. $(R X 1848,94)$

- In the person of Ivan Andreevic Krylov we saw a Russian in the true sense of the word. with all the qualities and weaknesses that are peculiar to us exclusively. His genius as a fabulist, acknowledged not only in Russia but also across all of Europe, did not protect him from our usual unevenness in life, in the midst of which Russians are sometimes capable of surprising everybody with the perspicacity and keenness of their minds and sometimes they indulge in unpardonable lack of passion in their affairs.'

(226) Vot za čto tebja gluboko / Ja ljublju, rodnaja Rus"! / Ne bezdarna ta priroda, / Ne pogib ešce tot kraj, ; C'to vyvodit iz naroda / Stol'ko slavnyx, toi-znaj!... (RS III 1907, 159: N. A. Nekrasov)

'This is why I love you deeply, dear Russia! Rest assured that such nature is not inept and such land has not yet perished that can draw from the nation (narod) so many illustrious people.'

(227) V 1919 godu belye zaxvatili gorod Caricyn. Fto byl očen' važnyj dlja Krasnoj Armii punkt, i partija poslala tuda tovarišča Stalina. On tak organizoval delo, čto belye byli razbity. Rabočie Caricyna gordjatsja tem. čto ix gorod teper' nazyvaetsja Stalingradom. Krasnye bystro pošli k Voronežu, 
gde byli belye. Konnim korpusom komandoval Budennyj, a Vtoroj armiej Klim Vorošilov. Pod rukovodstvom vożdej Krasnaja Armija pobedila. (MLR 1938, 1:51-52)

'In 1919 the Whites conquered the city of Caricyn. This was a very important spot for the Red Army and the party sent comrade Stalin there. He organized things so that the Whites were defeated. The Caricyn workers are proud that their city is now called Stalingrad. The Reds quickly moved to Voronež where the Whites were. Budennyj was commanding the cavalry corps and Klim Vorošilov the Second army. Under the guidance of the commanders the Red Army won a victory.'

(228) Ljubov' k čeloveku, svoemu narodu, želanie osvobodit' narod ot stradanij - glavnaja mysl' vsex knig velikogo gumanista Dostoevskogo. Dostoevskij nadejalsja i veril, čto ego narod budet sčastliv. On pisal: "Ja ne xoču žit' inače, kak s veroj, čto vse naši devjanosto millionov russkix (ili skol'ko ix budet) budut vse kogda-nibud' obrazovany i sčastlivy." (RB 1999, 291)

'Love for humanity, for his nation (narod), a desire to liberate the people (narod) from suffering - this is the main idea of all the books of the great humanist Dostoevskij. He hoped and trusted that his nation (narod) would be happy. He wrote: "I can only go on living if I trust that all our ninety million Russians (or as many as there will be) will at some point be educated and happy."”

(229) Kakoj čelovek ne ljubit zanimat'sja? Lentjaj. Lentjaja neð̌ego Žalet'. Lentjai vsegda skučajut. Trud delaet čeloveka veselym i bodrym. Vsjakij trud voznagraždaetsja. Ćto vy polučaete za svoj trud? Kakoj trud, takaja plata. Vy vsegda rabotaete. Net, ne vsegda, inogda i prazdnuju. (NSRJa 1875, 31-32)

'What [kind of a] person does not like to work? A lazybones. One should not pity the lazybones. They are always bored. Work makes a person gay and cheerful. Any work is rewarded. What are you paid for your work? The remuneration depends on the work. You are always working. No, not always, sometimes I relax.'

(230) Cem bol'še i uznaval moego novogo znakomogo, tem sil'nee ja $\mathrm{k}$ nemu privjazyvalsja. Ėto byla prjamaja russkaja duša, pravdivaja, čestnaja. prostaja; on byl očen' mil i umen; ne poljubit' ego ne bylo vozmožnosti. (KRS s.a. [1890-1899?]. 74)

'The better I came to know my new acquaintance, the more attached I was to him. He was a straightforward Russian soul, upright, honest and simple. He was very kind and intelligent: it was impossible not to love him.' 
(231) Seli deti vokrug deda. A on stal im rasskazyvat' o krepkoj družbe, kotoraja svjazyvaet russkix i bolgar. Rasskazal, kak russkie osvobodili Bolgariju $i$ ot turok, $i$ ot nemcev, i ot zlodeev-bogačej; kak Sovetskij Sojuz pomog bolgaram sozdat' svoe sobst vennoe gosudarstvo i vsegda pomogaet $v$ trudnuju minutu. Stali vspominat', čto polučila Bolgarija ot Sovetskogo Sojuza: xlopok, mašiny, knigi, lekarstva - vsego ne upomniš'. A ded tol'ko sprašivaet:

- A ešče čto?

- Takaja byl' lučše vsjakoj skazki, - nakonec skazal ded. - Vsegda znaeš', čto u tebja est' nastojašcij drug, sil'nyj i vemyj zaščitnik. Sam nikogda ne obidit $i$ drugim $v$ obidu ne dast. A družba $u$ nas $s$ nim nerušimaja - ne na žizn', a na smert'. (RJa 1952, 95)

'The children sat around the old man. And he started telling them about the firm friendship that binds Russians and Bulgarians. He told them how the Russians liberated Bulgaria from the Turks and from the Germans and from the rich rascals; how the Soviet Union helped the Bulgarians create their own state and always helps them overcome difficulties. They staned recalling what Bulgaria has received from the Soviet Union: cotton, machines, books, pharmaceutical drugs, it was difficult to remember everything. But the old man went on asking:

"What else?"

"Such a true story is better than a fairy tale," the old man said at last. "You always know that you have a real friend, a powerful and loyal protector. He would never insult you and won t allow others to do it. And the friendship with him is inviolable, it will carry you through thick and thin."

(232) Mysli vernulis' $k$ tomu dalckomu vrcmeni, kogda $v$ strane buševala graždanskaja vojna $i$ on, molodoj, tridcatiletnij vrač, operiroval i krasnyx $i$ belyx: delo bylo $\vee$ Kieve, $\vee$ gospitale. Togda on mog rabotat' sutkami $i$ bol'se... Da, byl ty i ostuvalsja na zemle bespokojnym časovym, vskakival po pervomu zovu i šel, kak sejčas $v$ noč', $v$ burany i sljakot'. Vse-taki interesnaja štuka - žizn'! Trevoga za nee stala tvoej vtoroj suščnost'ju. daže vozrast i prišeď̌ij vmeste s nim opyt ne izgladili ostroty čuvstva. (CRR 1997, 23-24)

'His thoughts returned to the distant time when the civil war was raging in the country and he, a young, thiny-year-old physician would operate both on Reds and Whites. This was in Kiev in a military hospital. He could work around the clock then... Yes, you were and remained a restless guard on earth; you were ready to jump at the first call and go like now in the middle of the night through snowstorms and slush. Nevertheless, what an interesting thing life is! The anxiety for it has become your second nature, and even age 
and the experience that has come with it did not reduce the intensity of emotion.'

According to their choice, considered more as a tendency than in absolute terms, textbooks can be grouped as follows: (A) Interest in the ideal qualities of the relevant group focuses the attention on exemplary individuals presented against a background of ordinary people (RG 1750; URJa 1973; RREG 1992). (B) The ordinary is dissolved into the exemplary: there is no such thing as ordinary people. If one takes a close look at the ordinary characters, one sees that they are actually quite extraordinary: they all have their personalities (RJaV 1976; RST 1985; V 2 1991; CRR 1997 [Part 1]). (C) As the emphasis is on the typical, generic and ordinary group members are shown going hand in hand $(R X$ 1894; RR III 1914; MPMR 1998). (D) The orientation is to the everyday; therefore, the ordinary type predominates (RU 1902; NRG 1935; RJaIS 1974; AR 1980; BR 1981; NIR 2000; REW 2000). The cult of narod is compatible with all approaches except (D), but it comes through most convincingly in (B). As (A) displays the most importunate style, it fits best the Proselytizing Model. By the way, only 10 per cent of Russians in 1994 would agree that great (or, in my terminology, exemplary) personalities are the most germane representatives of narod (Levada 1995, 223). Both (B) and (C) would work for the Broad CommonGround Model. (D) is the automatic choice of the Narrow Common-Ground Model. Let us have a look at the realizations of these choices in several textbooks adhering to different identity discourses.

RR III 1914 displays a strong didactic tendency. Many of its characters are there with the explicit objective to teach readers to be better persons. The textbook acquaints its readership with the ethnic groups that inhabit Russia as well as ordinary and some extraordinary specific members of narod. Russians (velikorussy RR III 1914, 137), Ukrainians (imalorussy RR III 1914, 142), the inhabitants of the European north (RR III 1914, 143-144). Finns (RR III 1914, 146), Belorussians and Lithuanians (RR III 1914, 147), Poles (RR III I'iił. 147) 
and so on are characterized generically always in positive light, with special attention to national character, livelihood, language and religion. The majority of textbook characters, however, are ordinary members of narod presented as individuals. Charity to the poor, ill and homeless and kindness to animals are advertised insistently. Loyalty, mutual help and love between people are praised. The rulers of Russia from Rjurik to Alexander III are the extraordinary members on which a series of short essays at the end of the book focuses (RR III 1914, 155-181). Very few extraordinary members of lower rank such as the conquerer of Siberia, Ermak Timofeevic (RR III 1914, 163), or Koz'ma Minin and Dmitrij Požarskij, heroes in the war against the invading Polish army (RR III 1914, 165), are incorporated in these essays. It is noteworthy that extraordinary members of narod are set on a pedestal and separated from the mass of generic and ordinary members who constitute the bulk of textbook characters.

The series of exemplary members of society available in URJa 1973 includes Lenin (URJA 1973, 1:78-80, 114, 164, 172, 242-243; 2:204-208), the first cosmonaut Jurij Gagarin (URJa 1973, 1:72: 2, 165-170), the Soviet poet Vladimir Majakovskij (URJa 1973 1:81), the Soviet Civil War hero and writer Nikolaj Ostrovskij (URJa 1973, 2:247-248), nineteenth century authors Puškin (URJA 1973, 1:80) and Lev Tolstoj (URJa 1973, 1:100-101), eighteenth-century scholar Mixail Lomonosov (URJa 1973, 1:126: 2:178). The masses of ordinary people are represented by the village teacher Varvara Manynova (URJa 1973 2:9-14), the construction workers building the Bratsk power station (URJa 1973, $1: 152,257$ ), the farmers at the kolkhoz in the Kasino village (URJa 1973, 1:162163), steel founder Egor Gusev (URJA 1973, 1:209-210), students and farmers ploughing the virgin soil (URJa 1973, 1:273-274; 2:68-73). Soviet soldiers in Stalingrad (URJa 1973, 2:107-112) and many others whose main purpose in life is to do decently their prosaic but necessary jobs, looking up at those pcaks. They are the notorious vintiki 'screws. parts, picces' of the social machine. 
The characters in RJaV 1976 are residents of a typical apartment building in Moscow: mother-heroine Nina Nikolaevna; the talented and communityoriented architect Mixail Petrovic; the electrician Miša who plays Paganini in his spare time, crane-operator Klava who is a Member of Parliament; Sergej Frolov, the radio fan who happened to be the first to intercept the signals emitted by the Soviet sputnik; health nut Aleksej Fedorovic, who goes for a swim in winter; a bus driver studying English; the young but already famous physicist Aleksej Vasil'evič; the talented young ballerina Lena.

While these characters are fictitious, RST 1985 chooses and describes real people. It talks about Lenin; infant prodigy Kostja Slavin; linguist Lev Šcerba; physiologist Ivan Pavlov; nineteenth-century Russian writer Anton Cexov; kosmonaut Svetlana Savickaja; actress Ljudmila Savel'eva, who starred as Nataša Rostova in the War and Peace movie; doctor Leonid Rogozov, who performed on himself a successful surgery of appendicitis in the Arctic; Mixail Lomonosov, the eighteenth-century scholar; high banking official Vladimir Alximov; pedagogue Vasilij Suxomlinskij; and opera singer Elena Obrazcova.

The characters in AR 1980, on the other hand, are bereft of noisily advertised moral qualities. They are neither particularly successful by the standards of Soviet society, nor are they gray non-entities. The principal character, Kolja, can oversleep and get drunk, but he thinks on his own and harbours warm feelings.

Illustrations help carry through the image of the Russian-speaking subject endowed with the relevant identities. Some textbooks favour images of generie people who may be granted age (Illustration 31), gender (Illustration 32), ethnic (IIlustrations 33 and 34), racial (Illustration 35), religious (Illustration 36), class (Illustration 37) or professional (Illustations 38 to 42) identities. The same image can feature more than one identity. This is how we can see an old man (age + gender), a woman-painter (gender + profession) and so on. 
The generic approach to image also makes it possible to distinguish between Self and Other (Illustrations 43 and 44). Such differences have traditionally been downplayed, as Illustration 45 shows.

If a textbook shows a uniform preference for one identity, it may leave the impression that all Russian speakers are holders of that identity. Especially striking from this point of view are some Imperial textbooks addressing inorodcy (DD 1902; PKORJa 1913; RR I 1914). Their rustic pictures leave the impression that all people in Russia must be peasants. Thus, the word staruxa 'old woman' is illustrated in PKORJa 1913, 18 with a picture of an old peasant woman (Illustration 46). The only image of a non-peasant in this book is that of the teacher (Illustration 47). As inorodcy had first-hand experience of life in Russia, they knew too well that that was not the case. Obviously, the images in these textbooks do not strive to offer an encyclopedic image of Russia. They pursue a different goal: they describe the world of the audience as best they can in order to lean on the familiar images in the introduction of the new verbal signs to go with them. This visual peculiarity of some textbooks for inorodcy is one of their distinctive characteristics in comparison with the textbooks for inostrancy. My guess is that initially illustrations were not even considered an option for the foreign audience. Illustrations appear in textbooks for inorodcy because these textbooks as a rule were addressing children, whereas the typical textbook for the foreign audience was addressing adults. ${ }^{34}$ The only Imperial textbook for inosirancy I have seen that features illustrations is FSR s.a. [1918?]. Its author, J. Solomonoff, recognizes in the preface that he is indebted for many of his readings and illustrations to Russkaja reč (see RR 1914). FSR s.a. [1918?]

\footnotetext{
34 The earliest use of Illustrations for the purposes of second-language learning I know of (HK 1789) also addresses young people. It contains illustrations described in parallel Russian. French and German texts. which - as the author suggests in the preface - can be used to discuss with ycung students matters of pedagogical interest in one of these languages. The use of illustrations to prompt discussion is very similar in the future practices reflected in the SLL discursive formation. These premodern illustrations are. however, very different in character from those which were to become a part of the SLLL discursive formation.
} 
reproduced illustrations in general use in the textbooks for inorodcy published inside Russia.

Alternatively, other textbooks try to individualize their images. The easiest way to do this is to provide photos instead of drawings (Illustrations 48 and 49). This is an approach adopted as a particl or total solution in RJaV 1976, BR 1981, RST 1985, P 2 1996, MPMR 1998, RB 1999 and R 2000. Photos do not, however, automatically mean individualization as we can see in Illustrations 50 and 51. Visually individual characters were created for V 21991 (by V. Xudjakov and I. N. Ćibiljaev), RJaV 1995 (by S. Vasil'ev), PFK 1995 (by I. N. Čibiljaev and S. V. Semenov), RB 1999 (by V. Karasyov) and R 2000 (by A. N. Novikova). A characteristic of this category of illustrations is that people are presented as recognizable individuals; moreover, one can even get a feeling of the mood in which they were in the moment when the artist captured their image. For instance, in the pictorial vocabulary list that introduces the basic Russian words for human beings classified by gender and age, we find the following images (Illustration 52). Such visual signs are more informative than the verbal ones they accompany. The visual characterization of people comes in a variety of styles (Illustrations 53 and 54). Naturally, identities can also be represented in this group of illustrations but this is done now not in the minimalist manner of the generic illustrations as we can see in Illustrations 55 to 58 , where racial, ethnic and class identity is marked on specific rather than generic people. Visual individualization is one way in which images can become complementary to narrative, as Illustration 18 demonstrates.

One expects to be able to recognize the exemplary members of naroa' if they are presented in image. Most of the time it is so (Illustrations 59 and 60) but not always (Illustration 61). This tells us something about the opposition generic vs. specific in its visual embodiment. As we saw, an important characteristic of some discourses, including the Communist discourse, is that the grouf li:kes

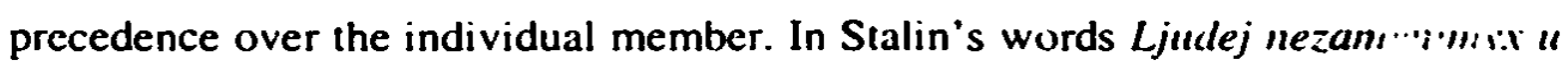


nas net 'There are no irreplaceable people in our country'. Gagarin is important only because of his symbolic role as the first human being in outer space. This is what the picture shows: a cosmonaut in full attire. The individual who actually played the role is difficult to distinguish behind the bright smile.

Having looked at the images of people that descriptive illustrations offer, one can conclude that ideally they support with visual signs the corresponding identity discourse nested in narrative form in the textbook. Generic images would not contradict a narrative presentation of narod of types (A), (C) and (D), but they will probably have to be supplemented with (individualized?) images of the exemplary members of narod. Certainly generic images are the only ones possible in category (C). Individualized images would work for (A), (B) and (D) but they are most appropriate for (A) and (B). Thus, depending on the choice between generic and individualized images types, (A) and (D) split into subtypes. Perhaps we can take it for granted that in category (A) the images of exemplary members of narod provide all the necessary individualization one may wish for. In category (D), however, the choice of images can have serious repercussions on the final impression that readers have of the speaking subject with all its identities: a schematic hat rack or a warm-blooded human being. Table 4 provides an overview of the representations of narod in image and narrative. It should be emphasized again that we arc dealing here with tendencies and not with absolute adherence to types.

\begin{tabular}{|l|l|l|l|l|}
\hline & $\begin{array}{l}\text { Narrative Type } \\
\text { (A): Exemplary } \\
\text { \& Ordinary }\end{array}$ & $\begin{array}{l}\text { Narrative Type } \\
\text { (B) Ordinary is } \\
\text { Exiraordinary }\end{array}$ & $\begin{array}{l}\text { Narralive Type } \\
\text { (C) The Typical } \\
\text { in Generic \& } \\
\text { Ordinary }\end{array}$ & $\begin{array}{l}\text { Narrative Type } \\
\text { (D) Ordinary }\end{array}$ \\
\hline Generic Images & + & - & + & + \\
\hline $\begin{array}{l}\text { Individualized } \\
\text { Images of } \\
\text { Ordinary People }\end{array}$ & + & + & - & + \\
\hline $\begin{array}{l}\text { Images of } \\
\text { Exemplary } \\
\text { Members of } \\
\text { narod }\end{array}$ & + & - & - & - \\
\hline
\end{tabular}

Table \&. Narod: Correspondences of visual and verbal signs 
V 21991 and RB 1999 are instances of type (A) individualized, whereas URJa 1969 and URJa 1973 offer visually different instances of type (A) generic. Due to their photos, RJaV 1976 and RST 1985 support with adequately individualized images their narratives of type (B). In my collection there are no illustrated textbooks of type (C). RJaV 1995 and PFK 1995 are instances of type (D) individualized, whereas PKORJa 1913 and SLR 1993 illustrate the same type in its generic modification.

Which individual members of narod are its metonymical summarizing symbols? The point of view of Autocratic discourse is clear: it is the emperor (Illustration 62). Communist discourse has oscillated over time between Lenin on his own and Lenin accompanied by Stalin, who is of course "the Lenin of today". The Bridging discourse had to look hard and reach back in search of convincing summarizing symbols. It is still experimenting with names that range from St. Sergij Radonežskij to Andrej Saxarov. Such data find confirmation beyond textbooks. For instance, Saxarov's role in history was seen in a positive light by $65 \%$ of respondents in a 1994 sociological survey, whereas only $44 \%$ continued to evaluate Lenin's role positively and $36 \%$ and $25 \%$ the roles of Nicholas II and Stalin, respectively (Levada 1995, 6). A summarizing symbol of narod in all periods and discourses has, however, been A. S. Puškin. The Autocratic discourse tries to convince us of Puškin's unswerving loyalty to autocracy, whereas later he was presented as its implacable enemy. He is reported to have said on his deathbed:

(233) Skaži Gosudarju, [...] čto mne žal' umeret'; byl by ves' Ego. Skaži, čto ja Emu želaju dolgago, dolgago carstvovanija, čto ja Emu želaju sčast'a v Ego syne, sčast'ja $\vee$ Ego Rossii. (RX 1848, 22)

'Tell His Majesty $[\ldots]$ that I regret dying; I would have remained otherwise to His service without reservations. Tell Him that I wish Him a long, long reign, good luck with His son and His Russia.'

Communist discourse holds the monarchy responsible for Puškin ` death: 
(234) Delo došlo do duèli. Pravitel'stvo ob ètom znalo, no Puškina pri dvore ne ljubili i duèli ne pomešali. (RMLR 1947, 275)

The conflict poured out into a duel. The government knew about it but Puškin was not in favour at the court and the duel was not prevented.'

The Bridging discourse does not go that far but insists that Puškin was systematically humiliated by the emperor:

(235) Car' xotel, čtoby Natal'ja Nikolaevna tancevala na pridvornyx balax, poètomu Puškinu bylo dano pridvornoe zvanie "kamer-junkera" - zvanie, kotoroe davalos' vosemnadcatiletnim junošam. Puškin byl oskorblen, no dolžen byl ezdit' na èti baly. (ČRR 1997, 56)

'As the Tsar wanted Natal'ja Nikolaevna to dance at the court balls, Puškin was conferred the court title "gentleman of the Emperor's bed chamber", title that was usually granted to eighteen year olds. Puskin was offended but he had to attend these balls.'

As a reality check, I would like to refer to a contemporary study of Puškin. Analysing the circumstances that contributed to Puškin's unprecedented glory, A. 1. Rejtblat concludes that both the extraordinary benevolence of Nicholas I and Puskin's opposition to the regime helped him win the love of his contemporaries (Rejtblat 2001, 66). Such balance and objectivity cannot. however, serve an identity discourse. which has no use for a summarizing symbol that does not fit the overall picture. This is why it adapts the symbols it has borrowed from its predecessors to its needs, leaving in them only the aspects that bolster it.

A constant characteristic of any metonymic summarizing symbol of narod is the mutual emotional bond between the symbol and the whole it represents. The Autocratic discourse even had an explicit justification: as the emperor was the Christian conscience of Russia, relations between subjects and monarch required absolute obedience by the former to the latter (Riasanovsky $1961,98)$. Thus, we are told the story of the argument that Peter I once had with the King of Denmark about the quality of their respective armies (in RX 1880 , 115-117 and RS III 1898, 125). As they could not agree whose army was 
superior, Peter proposed a test. Both monarchs were to call a soldier from their guard and order them to jump out of the window. Predictably, the Danish soldier assessed the danger and asked his king for permission to go home to say farewell to his family.

(236) Zatem Gosudar' pozval grenadera s gauptvaxty. Grenader vošel. "Zdorovo, tovarišč"” - "Zdravija želaju Vašemu Imperatorskomu Veličestvu!" - "Podojdi sjuda!" - Grenader podošel. - "Prygaj sejčas v okno, da s razbegu!" - "V kotoroe prikažete, Vałe Veličestvo, v èto?" - “Da, v èto." I grenader $v$ odin mig vskočil uže na podokonnik, perekrestilsja i rynulsja bylo golovoju vpered, tak čto Gosudar' edva uspel uxvatit' ego za nogi. Gosudar' obnjal ego, odaril i otpustil, a Korol' požal plečami i skazal: “Zaviduju Vam, Gosudar', čto u Vas takie soldaty." (RS III 1898, 125)

"Afterwards His Majesty called a grenadier from the guardroom. The grenadier came in. "Hi fellow!" "To Your Majesty's service!" "Come here!" The grenadier approached. "Run now to the window and jump out!" "Which window do you wish me to jump out of, Your Majesty, this one?" "Yes, this one." And the next moment the grenadier had already leaped on the windowsill, made the sign of the cross and was ready to dash out head on, so that the Emperor barely had time to catch him by the legs. The Emperor embraced him, gave him a present and released him, whereas the King shrugged his shoulders and said: "I envy you, Sire, that you have such soldiers."

The bond, however, goes beyond simple obedience and, significantly, is as characteristic of other discourses with their summarizing symbols. It involves harmony, mutual trust and love. Further quotations from my collection of Russian second-language textbooks, whose number could have easily been tripled, support this claim:

(237) Takoe izjavlenie obščej skorbi menja gluboko trogalo; v Russkix, kotorym doroga otečestvennaja slava, ono bylo neudivitel'no; no učastie inozemcev bylo dlja menja usladitel'noju nečajannost'ju. My terjali svoe, mudreno li, čto my gorevali? No ix čto tak trogalo? Otvečat' netrudno. Genij obšcee dobro; $v$ poklonenii geniju vse narody rodnyja: $i$ kogda on bezvremenno pokidact zemlju, vse provožajut ego s odinakoju bratskoju skorbiju. Puškin po svoemu geniju. byl sobstvennost'ju ne tol'ko Rossı, no i celoj Evropy; potomu-to i mnogie inozemcy prixodili k dicri ego s pečaliju sobstvennoju, i o našem Puškine požaleli, kak budto i svoc!n. (RX 1 \&.4S, 25) 
'Such an expression of general mourning [at Puškin's death] touched me deeply. It was not surprising in Russians who treasured the glory of the fatherland, but the empathy of foreigners was for me an unexpected delectation. We were losing our own; no wonder that we were grieving. But what moved them? It is not difficult to answer. A genius is a common good. In their worship of a genius all nations are related. And when he prematurely leaves the earth, everybody sees him off with the same brotherly sorrow. As a genius, Puškin was not only Russia's but also Europe's possession. That is why many foreigners came to his door with their own grief and moumed our Puškin as if he was their own.'

(238) Gosudareva volja svjaščenna dlja každago russkago. ( $\mathrm{RX} 1880,19)$

'The emperor's will is sacred to every Russian.'

(239) Vlast' Gosudarja velikaja; čto On prikažet, my dolžny ispolnjat' besprekoslovno. No samoderžavnyj Gosudar' naš est' i miloserdyj otec: On zabotitsja, čtoby vsem nam bylo xorošo i spokojno. (DD 1902, 113)

'The Emperor's power is great. We must carry out unquestioningly what He has ordered. But our autocratic Emperor is a charitable father: He takes care that we all feel well and at ease.'

(240) S toj pory Dom Romanovyx blagopolučno carstvuet i ponyne. Mixailu Feodoroviču $v$ to vremja bylo vsego 16 let. Nesmotrja na krajne bedstvennoe položenie gosudarstva, razorennago $v$ smutnoe vremja, molodoj car' vodvoril $\checkmark$ nem porjadok i uspokoil ego ot vragov. Narod dnužno podderžival carja $v$ ego zabotax i ničego ne ščadil dlja obščej pol’zy. (RM 1904, 197-199)

'The Romanov dynasty fias felicitously reigned ever since. Mixail Feodorovic was at that time only sixteen. Despite the extremely disastrous situation of the state destroyed during the time of troubles, the young tsar established order in it and safeguarded it against enemies. The people (narod) unanimously supported the tsar in his concerns and did not spare anything for the public well-being.

(241) Desjatki tysjač rabočix vostorženno vstrečajut svocgo voždja. Gremit "Intemacional". [...] Krugom bodrye lica. Priexal vožd'. S vostorgom i ljubov'ju vse smotrjat na Vladimira Il'iča. Vladimir II'ič - v Rossii, v revoljucionnoj Rossii, posle dolgix let izgnanija. Revoljucionnaja Rossija obrela nastojaščcgo voždja. Načinactsja novaja glava $v$ istorii meždunarodnoj proletarskoj revoljucii. (RKG 1931, 217) 
'Tens of thousands of workers enthusiastically welcome their leader. L'Intemationale is playing. [...] There are cheerful faces around. The leader has arrived. Everybody is looking at Vladimir Il'ic with delight and love. Vladimir Il'ic is in Russia, in revolutionary Russia, after many years of exile. Revolutionary Russia has found a real leader. A new chapter in the history of the international proletarian revolution is about to begin.'

(242) Mnogo pesen poet naš sovetskij narod / Nad poljami, lesami gustymi. $/ V$ každoj pesne zvučit, v každoj pesne živet / Vsenarodnoe Stalina imja. [...] Stalin - èto narod, čto $k$ pobedam idet /Po veršinam podoblačnyx sklonov. I Stalin - naši dela, Stalin - kryl'ja orla/ Stalin - volja i um millionov. (RMLR 1947, 436-437)

'Our Soviet nation (narod) sings many songs over the fields and the thick forests. Stalin's name, familiar nation-wide, lives and sounds in every song. [...] Stalin - this is the nation (narod) walking near the clouds from peak to peak towards victory. Stalin - these are our deeds. Stalin - these are eagle's wings. Stalin - this is the will and the brain of millions.'

(243) Smert' Puškina pokazala, kak on ljubim narodom: prostit'sja s poètom prišli ne tol'ko ego druz'ja, no i ljudi raznogo zvanija. Nekotorye sovremenniki govorili, čto $v$ èti dni u Puškina perebyvalo 30-50 tysjač celovek. (ČRR 1997, 56)

'Puskin's death showed how beloved he was by the people (narod). Not only his friends but also people of various rank came to bid farewell to the poet. Some contemporaries said that during those days Puškin's home was visited by thiny to fifty thousand people.'

(244) Sergij Radonežskij. Ėto imja čeloveka, kotoryj sobiralsja prožit' žizn' otక̌el'nikom, no prožil ee faktičeski vmeste s narodom i dlja naroda, stav ego duxovnym učitelem v surovye dlja Rusi gody tataro-mongol'skogo iga. (ČRR 1997, 51)

'Sergij Radonežskij. This is the name of a person who had intended to spend his life as a hermit but he spent it in fact together with the people (narod) and for the people (narod), having become their spiritual leader during the years of the Tatar-Mongol yoke that were grim for Russia.'

(245) Mnogie nazyvali Andreja Dmitrieviča Saxarova - mjagkogo, dobrogo, intelligentnogo čeloveka $i v$ to že vremja besstrašnogo, beskompromissnogo borca - sovest'ju naroda, a akademik D. S. Lixačev napisal o nem: “... On byl nastojaščij prorok. Prorok $v$ drevnem, iskonnom smysle étogo slova. to est' čelovek, prizyvajuščij svoix sovremennikov $k$ nravstvennomu 
obnovleniju radi budušcego. I kak vsjakij prorok, on ne byl ponjat $i$ byl izgnan iz svoego goroda". (CRR 1997, 77)

'Many called Andrej Dmitrievic Saxarov, who was a gentle, kind and intelligent person and at the same time a courageous and uncompromising fighter, the conscience of the people (narod). Member of the Academy D. S. Lixačev wrote about him: "... He was a true prophet; a prophet in the ancient, authentic meaning of this word, in other words, a person urging his contemporaries towards moral revival in the name of the future. And like every prophet he was misunderstood and exiled from his city.'

Lenin is the summarizing symbol of narod in the Communist discourse. Everything about Lenin is important and finds a place in textbooks of the Proselytizing Model: his biography, his role in the October Revolution and the building of the Soviet state, and, of course, his views on reading, learning and second-language acquisition. The Dissident discourse. on the other hand. accords to Lenin only a modest place in the discussion of grammatical issues such as the spatial meaning of prepositions or verbal aspect: he is treated without courtesy and denied his symbolic status (Illustration 63). The contrast between the place of Lenin in Communist discourse, as in (246) and (247), and Dissident discourse, as in (248), creates a comic effect, as intended. The Russian student Volodja asks his African friend Dialo whether he knows which square this is. Dialo of course knows. Have you been here before, Volodja asks:

(246) Net, net byl, no ja smotrel fil'm "Moskva - stolica SSSR". Ja znaju. čto èto Krasnaja ploščad'. Sleva Mavzolej Lenina, a èto Kreml'. Zdes' žil i rabotal Vladimir Il'iž Lcnin. (URJa 1973, 1: 78).

'No. I haven't. But I have seen the documentary Moscow, the capital of the USSR. I know that this is the Red Square. To the left is Lenin's Mausoleum, and this is the Kremlin. Vladimir Il'ič Lenin lived and worked here.'

(247) V zal vošel Lenin. Vse zakričali "Ura"! Vse smotreli na nego i aplodirovali emu. [...] Lenin znal, čto aplodirujut ne emu, aplodirujut socialističeskoj revoljucii, narod privetstvuet svoju velikuju pobedu [...]. Vdrug v zale stalo tixo. Lenin protjanul vpered ruku. "Tovarišci!," skazal on. "Raboče-krest'janskaja revoljucija, o ncobxodimosti kotoroj vse vremja govorili bol'ševiki, soveršilas'!" Tak načalas' novaja èra $v$ istorii vsego celovečestva (URJa 1973, 1:243). 
'Lenin entered the hall. Everybody cried "Hurray!" Everybody looked at him and applauded him. Lenin knew that they were applauding not him but the socialist revolution. The people (narod) applauded their own great victory. [...] Suddenly everybody in the hall was quiet. Lenin stretched out his hand. "Comrades!" he said. "The workers' and peasants' revolution of which Bolsheviks have been talking all along has taken place!" This is how a new era began in the history of humankind.'

(248) Kogda Lenin byl malen'kij, on ne mog s"est' pjat' tarelok supa. On mog s"est' tol'ko tri tarelki. Tol'ko v Oktjabre 1917 goda on $v$ pervyj raz smog s"est' pjat' tarelok supa. (BR 1981, 335).

'When Lenin was little, he couldn't eat five bowls of soup. He could only eat three. Only in October 1917 did he manage, for the first time, to eat five bowls of soup (tried and succeeded).'

In the Communist Broad Common-Ground Model and in the Bridging discourse (of any variety), Communist ideology is not discussed overtly and the name of Lenin is not mentioned except briefly or indirectly as a part of names of places, institutions and so on. (Biblioteka imeni Lenina, mavzolej Lenina, Leninskie gory). The reasons for that are different. The Communist discourse assumes that the audience might have other opinions on the matter and steers clear of it. It prefers to show Lenin's deeds as reflected in the thousands of mirrors of everyday life. Textbooks adhering to the Bridging discourse wish to avoid polemic with competing discourses in front of outsiders and simply offer their canon, which includes, according to RREG 1992, Puškin, Sergij Radonežskij, Andrej Rublev, Čajkovskij, Cexov and Rerix. Fourteenth-century saint Sergij Radonežskij, father of the Russian nation (otec russkoj nacii, RREG 1992, 41) is quietly substituted for Lenin, founder of the first socialist state in the world (osnovatel' pervogo v mire socialističeskogo gosudarstva, URJa 1973, 2:208). Sergij Radonežskij is the embodiment of the best qualities of a Russian person: sovestlivost', prostota, veniost' dolgu 'consciousness, simplicity, loyalty to duty' (RREG 1992, 38). He teaches people by his own example to live by the laws of conscience (učil ix žit' po zakonam sovesti ne slovami, a svoim primerom, 
RREG 1992, 39). At least one of his qualities, simplicity, has been associated with Lenin in Communist discourse. The best reflection of the Russian soul is held to be that found in Puskin's poems, Rublev's icons and Cajkovskij's music. The new name here in comparison with Communist discourse is Rublev. He and Sergij Radonežskij mark the rehabilitation of Orthodox Christianity.

This brings us to duša 'soul', the metaphorical summarizing symbol of narod. Starting with the realization that Russian duša is used more frequently than its English counterpart and in contexts in which speakers of English would rather use mind or hear, if anything, Anna Wierzbicka outlines three usages of the Russian word duša (Wierzbicka 1992, 31-63). Dušal is what distinguishes a human being from the animals. It is the invisible half of a person, the visible being a person's 'body'. Duša, belongs to the spiritual world and the body to the material world. This is the half of a person that accounts for that person's capacity for good. This folk philosophy has Christian roots. Although duša, is well documented, it never prevented declared atheists like the Russian communists, who avoided Christian concepts like grex 'sin' or satana 'Satan', from using it. Obviously, there is more to duša than duša,. Duša $a_{2}$ designates the moral and emotional core of a person, which is an organ of deeper, purer and more morally and spiritually coloured emotion than serdce 'heart'. Du.ša seat of mental life as a whole, as well as human will. One is expected to open this inscrutable and dynamic inner world to other people because what happens in it is essentially benevolent to others. Russian $d i{ }^{5} a_{\text {, }}$ and $d u s a_{2}$ are linked more closely than English soul and mind. Sometimes duša is used to denote a moral. religious and emotional complex in a way that implies overlapping of the two meanings. Such usage was indexed as $d u{ }^{\prime} a_{3}$ by Anna Wierzbicka.

It is $d u s a_{2}$ and $d u s a_{i}$ that are displayed over and over again in the actions and thoughts of generic, exemplary and ordinary members of narod. As I have noted, duša, became an extremely rare guest on the pages of Russian secondlanguage textbooks after the Imperial period, when it was represented like this: 
(249) U čeloveka est' duša i telo. Telo my vidim, a duša nevidima [...] K starosti sily celoveka načinajut slabet'; starik ploxo vidit, ploxo slyšit, skoro ustaet, kak mladenec; pamjat' u starika slabeet; - celovek približaetsja $k$ smerti. Telo ego postepenno vjanet, kak rastenie; tol'ko duša celoveka, kak sozdannaja po obrazu i podobiju Božiju, bessmertna. Žizn' naša v rukax Božiix; no my dolžny vsemi silami starat'sja izbegat' togo, čto vredit našemu zdorov'ju. (RS III 1907, 20)

"A person has a soul and a body. We see the body but the soul is invisible. [...] In one's old age a person gets weaker. An old person sees poorly, hears poorly and gets tired as quickly as a baby. An old person's memory slips away. A person nears death. His body gradually withers like a plant. Only the human soul, created after God's image and likeness, is immortal. Our life is in God's hands but we ought to do everything in our power to avoid anything that may harm our health.'

The direct mention of duša as in (230) outside the numerous set phrases in which the word participates or its detailed discussion is relatively rare, but see the story Rodnaja duša 'Kindred Spirit' about the profound loneliness of a Russian immigrant to the U.S., provoked by the scarcity of people with 'Russian souls' among his American acquaintances (LTL 1996, 228-231) or the excerpt by 1. V. Kireevskij on the two ways to be educated (RX 1872, 57-63): the European way that targets the mind alone and the Russian way that targets $d u{ }^{\prime} a_{3}$ in its complexity. One not only hears authors discuss duša but also detects it in the deeds of the holders of duša. Duša is the style of a person and one can visualize it in the art of Russian painters, whose paintings have been reproduced in textbooks, or in the contribution of graphic artists such as V. Karasyov and $A$. Alekseev. The components of Wierzbicka's definitions of duša could be illustrated with long lists of stories, of which I shall only give a few random examples. The overlap of the moral, emotional and intellectual aspects of duša that are its most striking characteristics in comparison to the West European 'mind' is the focus of the story about the schoolboy Sapožnikov (V 2 1991, 8688, 97-101). The importance of communication as a medium that enables people to see into each other's duša is shown in LTL 1996, 232-235 and CRR 1997, 2021 . The readiness to help people as a manifestation of the benevolence of duša to 
others is the theme of URJa 1969 2:110-115; RJaSI 1970, 291-292; RJaV 1976, 318; RST 1985, 340-342; CRR 1997, 22-23, 23-24, 25 and RB 1999, 222. Moreover, it is reiterated that other people's misfortune cannot serve as a basis for one's prosperity (ČRR 1997, 32-33). For RREG 1992 the laws of dusa overnule narrow ideological regulations or even everyday norms of behaviour. The examples abound: a teacher loses her job for gambling away money to a schoolboy who needed it badly but would not accept financial help from her; during the war a Russian soldier saves the life of a German boy and adopts him; a Russian woman grieves for all victims of the war and not for Russians only and gets rebuked.

Helping other people even at the risk of losing one's life serves as a proof of the vitality of one's duša. I can add some Imperial examples to the later evidence cited above. The quartermaster of a ship kept steering in spite of the fire on board the ship and saved everybody but himself (RS III 1898, 80-81; RR III 1914, 43-44). The old loyal servant Stepanyz jumped among wolves to distract them and save his master's family and was tom to pieces (RR III 1914, 40-41). While his companions were watching passively, Vasilij Marin, a peasant from the Jaroslavl' Province, saved a person in the fire of the Bolshoy Theatre in Moscow and won the recognition of people and the Emperor himself:

(250) Kogda Marin sošel na zemlju, spascnnyj užc naxodilsja na lestnice i byl vne vsjakoj opasnosti. Kak tol'ko Marin spustilsja vniz, zriteli napereryv drug pered drugom stali tesnit'sja $k$ dobromu čcloveku i prcdlagali emu den'gi, kto skol'ko mog. Sobrali mnogo dencg. - "Spasibo, molodec! daj tebe Bog zdorov'ja!" slyšalos' so vsex storon. O podvige Marina bylo dovedeno do svedenija Gosudarja Nikolaja Pavloviča. On poželal videt' lično Marina. Gosudar' obratilsja k Marinu s sledujušcimi slovami: "Spasibo za dobroe delo. Poceluj menja i rasskaži kak tebe Bog pomog!" V prostyx slovax Marin rasskazal, kak bylo delo. Blagosklonno vyslušav rasskaz, Gosudar' skazal: "stupaj s Bogom. a budet nużda, tak prixodi ko mne." Gosudar' velel nagradit' Marina medal'ju za spasenic pogibajušcix i vydat' emu denežnuju nagradu. (RS III 1898, 81-83)

'When Marin came down, the saved man was already on the ladder and was out of danger. As soon as Marin was on the ground, the witnesses surrounded 
the good man and started offering him money in eager rivalry, as much as each could afford. They collected a large sum of money. "Thank you, fine fellow! Let God give you health!" everybody was saying. The Emperor Nikolaj Pavlovič was told about Marin's brave act. He wished to meet with him personally. The Emperor addressed Marin with the following words: "Thank you for the good deed. Kiss me and tell me, how did God help you do what you did!" Marin told what had happened in simple words. Having listened to the story benevolently, His Majesty said: "Now go and let God be with you. Come to me if you encounter any problem." The Emperor ordered that Marin be given a medal for the rescue of people in danger and a money award.'

The Communist discourse adapted the duša symbol towards its goals. It declared heroic acts a necessity for the smooth flow of everyday life, or in Maksim Gor'kij's words, $V$ żizni vsegda est' mesto podvigu 'There is always room for heroic deeds in life'. This famous quotation comes from the 1895 short story Starwxa Izergil' 'Old Izergil' (Gor'kij 1968, 87). Soviet time accounts are numerous. For instance, we are told the story of Nikolaj Ostrovskij, a blind, incurably ill man who overcame suffering and became a writer (URJa 1969, 2:310-312), of a pilot with amputated legs (RJaSI 1970, 307-308, 314-315) and of a physician who operated on himself (RST 1985, 346-347). By glorifying such extraordinary heroic acts. Communist discourse was aiming to make them the norm and thus compensate for the lack of appropriate infrastructures, which would lower the need for heroism and limit it to the extraordinary situations where it belongs. Communist discourse exploited the treasures of dusa until enthusiasm started wearing thin, as the quick Internet search that supplied me with a series of ironic rephrasings of Gor'kij's adage would prove:

(251) V žizni vsegda est' mesto podvigu. No ego možno i ustupit.' (aforism.chat.ru/LZBR/izbr_gzn.htm)

'In life there always is a place for heroic deeds. But one can also yield it.'

(252) V żizni vsegda est' mesto podvigu. Nado tol'ko byt' podal'še ot ètogo mesta. (sh.udm.ru/humor/murphy.html) 
'In life there always is a place for heroic deeds. One should only be as far as possible from this place.'

(253) Ja soglasilsja by žit' na zemle celuju večnost', esli by prežde mne pokazali ugolok, gde ne vsegda est' mesto podvigu... (www.friendspartners.org/partners/rpiac/nashsovr/archive/1999/n7/bondar.htm)

'I would agree to live on earth forever if I was first shown a corner where there isn't always room for heroic deeds...'

Looking at the group of people relevant from the perspective of the Identity discursive formation, we encounter the same pattern: the Proselytizing Model likes to talk about the valuable whole itself (narod) and its generic and exemplary members, whereas the textbooks of the Broad Common-Ground Model may limit themselves just to specific people (ordinary and sometimes exemplary members), who upon closer inspection tum out to be holders of the immortal Russian duša 'soul' as befits members of narod, very much in tune with the findings of anthropologists (Pesmen 2000).

To summarize, the focus in this chapter was on the concepts of identity discourses present in the field of concomitance of the SLL discursive formation. Russian second-language textbooks give a fair idea of the valuable wholes that constitute the basis for the various identity discourses in terms of people who participate in the events that take place in a certain territory. Each whole may be represented as it is or through its metonymical or metaphorical summarizing symbols. Narratives and images work together to produce the effect at which they aim. The manner of statement favoured by a textbook depends on the model it adheres to. The subtler Broad Common-Ground Model prefers summarizing symbols, whereas the Proselytizing Model gocs for the whole package (valuable wholes and symbols). The major identity discourses that are represented are the "pure" Holy-Rus doxa, Civilized-World doxa and Communist discourse and the synthetic Autocratic, Mature Communist and Bridging discourses. 


\section{VII. 'I' and 'We': Private vs. Public}

The Russia-specific relations of individuals with the group to which they belong have been holding the attention of scholars inside and outside Russia. The consensus is that, throughout the tumultuous history of Russia, the group has prevailed over the individual. Evidence in support of this claim comes from various directions. On one hand, we are told that Russians have no equivalent for the English word privacy because "if one has nothing to hide, one does not need privacy" (Dabars with Vokhmina 1995, 61). On the other hand, it is well known that Slavophiles were praising sobornost' 'covenant', "the natural unanimity of all 'true' Russians" (Malia 1961, 287), whereas Communists considered dux kollektivizma 'team-playing spirit' a guiding principle of social life.

The move of the individual away from the limelight is achieved in Russian society by a variety of devices, including linguistic ones. Anna Wierzbicka talks about non-agentivity, "a lack of emphasis on the individual as an autonomous agent, 'achiever' and controller of events" and its expression by dative and infinitive constructions (Wierzbicka 1992, 395, 413-430). These and other Russian impersonal constructions make it possible to present events as happening to people independent of their will (Zaliznjak \& Levontina 1996; Arutjunova 1999, 793-814). Among the linguistic forms that serve this purpose one should also mention the prevalence of the nominal style over the verbal, especially in the more formal written varieties of Russian. All these are by necessity treated in Russian second-language textbooks but usually without reference to any cultural implications.

Furthermore, as the subordination of the individual's interests to those of the group has as one of its corollaries anti-commercialism and anti-materialism, scholars have wondered whether there were not "deep-rooted cultural, moral and 
psychological obstacles to market-building in Russia". In a thought-provoking article, Natalia Dinello (1998) interprets statistically interviews with sixty-one Russian bankers and comes to the conclusion that the perceptions of the Russian pioneers of money economy deviate from traditional Russian ideals and approximate those of their Western counterparts. Russian second-language textbooks provide evidence of the existence of both of Dinello's ideal types: Homo Orthodox and Homo Economicus. As expected, the former has a greater chronological depth, whereas the latter can be traced back to the Soviet period. Here again one sees clearly that the field of concomitance of SLL and the Identity discursive formations is narrower than the Identity discursive formation. During the Imperial period of Russian history there were groups that embraced the instrumental rationality and calculability of Homo Economicus. These were the groups responsible for the well-known Russian economic boom at the end of the nineteenth and the beginning of the twentieth century. The views of these groups are, however, not part of the field of concomitance. Instead, textbook readers until late in the Soviet period are exposed exclusively to opposition to the mercenary spirit stemming from group- and relationship-oriented identity discourses. I shall provide an idea of the typical representations of this area in the Autocratic, the Communist, the Dissident and the Bridging discourses.

In agreement with the value attached to narod and its summarizing symbol duša, an Imperial-time parable gives a categorical evaluation of the actions of four little boys who had never before seen peaches and to whom their father gave a peach cach. On the positive pole we have the eldest son. Sergej, who ate his peach and planted the stone in a pot and Volodja, who gave his peach to his ill friend Griła. The other two sons are seen in negative light. The youngest Vanja ate his peach and threw away the stone. He then asked his mother to give him half of her peach. His brother Vasja tasted Vanja's peach stone and found it bitter. He then sold his peach for ten copecks. His transaction is considered profiteering (baryšničat), becoming only to a torgaš 'huckster' (RR III 1914, 
16). The implication is that altruism, charity and industriousness are encouraged whereas egoism, defined so broadly as to include the entrepreneurial spirit praised so highly in the West, is condemned. The individual is subordinated to the group.

Communist discourse assumes that byt 'daily routine' presents no problem: it takes a short visit to the department store to buy a coat for Elena Petrovna and a suit for Nikolai Ivanovič. Money too is not an issue (URJa 1973 1:61). Characters praised by Communist discourse are overtly proud of their lack of practical grip, as Nikolaj Nikitic demonstrates in the short story Mečtatel'nica 'Dreamer'. He emphasizes that although he has grown flowers all his life, he has never sold a single one (RST 1985, 112).

Conversely, it is not alien to characters in Dissident discourse to think of money in a practical way, as the following heretical but realistic exchange shows: (254) Slušaj, ja davno xotel tebja sprosit' - začem ty pošel na ètot svoj filfak? Ty že kogda-to vyučilsja na šofera. Pošel by rabotat' na taksi, zarabatyval by kucu deneg, i gorja by ne znal. (AR 1980, 2)

'Listen, I have been thinking for a long time to ask you. Why did you choose to study at that Philological Faculty of yours? You have a driver's licence. Had you started working as a taxi driver, you would have eamed lots of money and lived happily.'

Many textbooks of the Bridging discourse share this realistic attitude towards money (e.g., NIR 2000, 90-91) although some inherited the disdain towards business and businessmen that, as we saw, finds justification across orhodox discourses albeit on different grounds. In V 2 1991, 45-46 the successful businessman Ėdik is presented, in contrast to other hard-working but poor characters, as someone who eats caviar, drinks cognac, has been married five times and sleeps all day because he is partying at night (see also Illustration 53). As he obviously cannot be bothered with work, the implication is that he must have obtained his wealth through illicit activity. In $R$ 2000, 66-67 readers are introduced in narrative and image to the semiliterate Vitja, who sells at the 
railroad station pirožki 'pies' baked by his sister. This is the humble beginning of private enterprise in post-Communist Russia, which by the time the textbook was published was already overcome, as becomes clear from the story itself. However, the bittemess provoked by the appearance of this group of people, called the New Russians (novye russkie), is still around. Beskorystie 'altruism' continues to be a highly valued human characteristic, but it has to prove itself today against a background of achievement-oriented positive qualities.

Viewed from the perspective of the valuable wholes of Russian identity discourses, the relationships of the individual and the group predictably appear in their temporal and spatial dimensions. Self as an individual human being has access to two temporal sequences: Self's own lifetime and the lifetime of the relevant whole. Depending on the vantage point, the relative importance attached to these sequences may be different. If Self is placed above the group, one can expect the events that comprise Self's life to take precedence over the canonic events of the group and vice versa. The Holy-Rus doxa required subordination of Self to the group and its values. This subordination manifested in the choice of the nameday as Self's annual celebration, among other things. This choice emphasizes that what matters in a person is first and foremost that person's affiliation with a patron saint. The Autocratic discourse inherited this perspective:

(255) Maminy imeniny. Včera mama byla imenninica. Ja s bratom i s sestricami pozdravili mamu. Ona byla očen' rada, kogda my propeli: Angel mamy, angel milyj,/Angel dobryj, ja molju:/ Soxrani nebesnoj siloj /Mamu miluju moju! K obedu sobralis' vse naši rodnye: deduška, babuška, tetuška i djadjuška. Oni takže pozdravili mamu so dnem angela i prinesli nam gostinca. (RM 1901, 74)

'Mum's nameday. Yesterday was Mum's nameday. My brother, my sisters and I congratulated Mum. She was very happy when we sang: "Mum's angel. dear angel, kind angel. I beg you, preserve with a heavenly power my dear Mum!" All our kin came to dinner: Grandfather, Grandmother, Aunt and Uncle. They also congratulated Mum with the day of her angel and brought us gifts.' 
As we know, until the 1917 Revolution Russians could only be given names that were included in the Orthodox Christian calendar (Comrie, Stone \& Polinsky 1996, 267-272), which means that everybody necessarily had a nameday. Mixail Zoščnko's short story Roza-Marija (1938) gives an idea of the period of transition towards a different system of naming that, even though shortlived, brought to the fore another annual celebration - the birthday (Zoshchenko 1963, 290-294). As a relic from the old system. Russians today and throughout the Soviet period have been using "incorrectly" imeniny 'nameday' and imeninnik (m.) imeninnica (f.) 'person whose nameday it is today', derivatives from imja 'name', to denote 'birthday' and 'person whose birthday it is today', respectively (Ožegov 1984, 220).

A reconciliation of nameday and birthday as a compromise between Orhodox Christian values and Westem individualism must have been characteristic of the late Imperial period. At least this is what the testimony of a Russian émigré in (171) makes us believe. Birthdays are much more salient than namedays among Soviet and post-Soviet Russians. If one is to judge by Russian second-language textbooks, birthdays are the only ones celebrated. Soviet birthday celebrations were very similar to those described for the post-Soviet period. They included a festive dinner, long conversations of the host with the guests and music (URJa 1969 1:248-249). Here is a post-Soviet account of birthday parties:

(256) $V$ restoranax obyčno otmečajut osobo važnye sobytija $v$ sem'e ili na rabote: svad'by, jubilei, tvorčeskie uspexi. Na dni roždenija, novogodnie prazniki druzej i znakomyx priglašajut domoj. Nakryvajut stol, gotovjat raznoobraznye salaty, gorjačie zakuski, pekut pirogi ili tort. Konečno, na vse prigotovlenija $k$ priemu gostej u xozjajki uxodit mnogo vremeni. No kak prijatno provesti večer $v$ krugu druzej, slušaja muzyku, tancuja ili razgovarivaja. (DGR 2000, 118)

'In restaurants one usually celebrates especially important family and jobrelated events: weddings, jubilees, professional achievements. Friends and acquaintances are invited at home to birthday and New Year parties. The table is laid, various salads and hot entrees are prepared. pies or a cake are 
baked. Of course, it takes a lot of the hostess's time to prepare for the party. But how pleasant it is to spend an evening surrounded by friends, listening to music and dancing or talking.'

Group space (one's home country, one's town, etc.) has traditionally also prevailed over individual space (one's home). Autocratic discourse subordinated one's home to the Church (God's home), as we saw in (162), to the Tsar's palace or, at the very least, to the houses that serve the community as a whole, as in the story Dobryj kupec 'The Good Merchant', from which the following excerpt comes:

(257) Dlja kakix èto žil'cov prigotovil kupec kvartiry? - sprašivajut drug druga sosedi. Kogda oba doma byli gotovy, pozval kupec $k$ sebe ne novosel'e svjašcennika, starostu cerkovnago i drugix požetnyx lic. Pomolilis' Bogu. Posle molebna kupec ob"javljaet, čto on žervuet èti dva doma dlja bednyx odinokix starikov i starux. I kapital bol'soj naznačaet dlja soderžanija bogadelen. A svoj dom naznačil $v$ Školu i prijut dlja sirot, i క̌kolu s prijutom takže kapitalom obespečil. Umer kupec, no pamjat' o nem ne umret vo veki. Zhivut stariki $v$ teple i dovol'stve, syty, odety, obuty, i moljat Boga za upokoj duši dobrago čeloveka. (RS III 1898, 87)

"What tenants has the merchant prepared these apartments for?" neighbours were asking each other. When both buildings were ready, the merchant invited the priest, the parish headman and other respected persons to a housewarming party. They prayed to God. After prayer, the merchant announced that he was donating these two buildings to the poor lonely old men and women and providing the almshouses with a generous endowment to cover their expenses. He had earmarked his own home for an orphanage and a school and also set aside funds for their maintenance. The merchant died but the memory of him will never die. The old people are keeping warm and content: they have their fill, they have clothes and shoes and they are praying to God for the repose of the good man's soul.'

Nevertheless, one's home is present as a part of the greater picture in the Autocratic discourse:

(258) Mnogo na svete mest, gde žit' privol'no, a vsjakago tjanet tuda gde rodilsja i żil s rodnymi svoimi. Tam vse emu znakomo i dorogo. Dorog emu vsjakij ugol $v$ rodnom dome; tut ešče malym rebenkom on v zybke kačalsja: vsjakij kustik v otcovskom sadu emu prijaten; mila emu rodnaja rečka, tam on s drugimi rebjatami lctom kupalsja: mil emu les. gde znaet on vsjakoe derevco, dorogo emu kladbiščc, gde sxoroneny ego dedy. (RS III 1898,100 ) 
'There are many places on earth where life is easy, but one is attracted to the place where one was bom and where one used to live with one's family. Everything is familiar and endearing there. Every corner in the house where one was born is dear to one's heart; here is the place where one's cradle had rocked; every shrub in father's garden is agreeable: the nearby river is lovely; that is where one used to swim with friends in the summer; one is fond of the forest where one knows every single tree, of the cemetery, where one's forerunners were buried.'

The Communist discourse goes further than the Autocratic discourse. Private space, as one finds it described by Svetlana Boym (1994, 121-159), is completely ignored. The assumption is that people need no real homes; they can just as well live in dormitories (as students and workers do) or in tents (as travellers and enthusiasts at the forefront of industrial development do). Nevertheless, most textbook characters live in comfortable separate apartments. Here is an early description of housing, not as it actually is (as remarked astutely in REB 1938, 4 in connection with similar self-serving descriptions of living standards) but as it should be in an ideal world, although the text seems to imply that we are shown reality as it is:

(259) V SSSR idet Široko razvemutoe žiliščnoe stroitel'stvo, stroitel'stvo domov dlja rabočix. Pri każdom zavode v SSSR vyrastajut novye doma, gde rabočie naxodjat zdorovye i kul'tumye uslovija žizni. Est' uže celye kvartaly takix novyx domov, celye novye goroda. Naš dom - odin iz takix domov. U nas est' vse udobstva: èlektrixeskoe osvešcenie, gaz, central'noe otoplenie, vanny, duš i t.d. Na každom ètaže est' balkony. Komnaty vysokie, $v$ nix bol'šie okna, na balkony vyxodjat stekljannye dveri, - vezde svet i cistyj vozdux. U nas est' kommunal'naja stolovaja i pračečnaja. Pri dome est' daže detskaja ploščadka $i$ jasli. Kogda rabotnicy uxodjat na rabotu, oni ostavljajut tam svoix detej. U nas est' nebol' ̌oj, no xorošij sad i sportploš̌adka, gde my igraem $v$ volej-bol i drugie igry. $V$ dome est' xorošij klub. $V$ klube u nas est' biblioteka, radio, komnata dlja ctenija i otdyxa, zal. Novye doma - ne tol'ko zdorovye žilišča, no i kul'tumye socialističeskie učreždenija. (RESW 1933, 75)

'In the USSR there is a broad campaign of residential building, building of homes for workers. New apartment buildings, where workers are offered healthy and decent conditions of life. grow by every plant in the USSR. There already are whole neighbourhoods of such new buildings, entire new cities. 
Ours is such a building. We have every convenience: electric light, gas, central heating, tubs, shower, etc. On every floor there is a balcony. The ceilings are high; the rooms have big windows; glass doors open to the balconies. There is light and clean air everywhere. We have a communal canteen and laundry. The building even has its own playground and kindergarten. When women workers go to work they leave their children there. We have a small but nice garden and a sports ground where we play volleyball and other games. There is a nice club in the building. In the club there is a library, a radio, a room for reading and relaxation and a hall. The new buildings are not only healthy residences but also socialist institutions of culture.'

The dichotomy between the two alternative perspectives (the individual vs. the group point of view) of varying relative weight in different societies and periods of time manifests in the treatment of the private and the public spheres of social life by that society. Erving Goffman's spatial and social separation of front and back regions in which social performances are carried out points to the possibility of keeping concealed potentially compromising features of interaction by controlling the setting (Goffman 1959; Giddens 1994, 207). Conformity to normative standards is characteristic of performances in the front regions. If we consider the valuable wholes discussed in chapter 6 from the point of view of the private/public contrast, we shall see that their spatial and the temporal dimensions easily split into private and public areas.

A second-language textbook is typically designed for use in the classroom and therefore belongs to the public sphere of life. It must, on the other hand, provide its readers with the necessary language resources to deal with private as well as public situations. This imposes on authors the necessity to deal somehow with both spheres while remaining situated in the public domain. This is the background against which descriptions of private life as if it were public appear in textbooks. This "dressing up of the private" to make it palatable in public situations is a peculiarity of the SLL discursive formation as a whole. Even though the private sphere as one encounters it in second-language textbooks is never truly private, authors may still show a wide range of variation in their definition of the boundary between private and public and of the ideal ratio 
between private and public matters in the object language portion of the textbook. As expected on the basis of the preceding discussion of the relationship of the individual and the group, one can range the orthodox discourses of our three historical periods in the order of growing openness of their respective private spheres as follows: the Communist, the Autccratic and, finally, the Bridging discourse.

Autocratic discourse represents the middle range. The allowed view of its private sphere is well rehearsed and controlled. In NSRJa 1875, for instance, the focus is on private life: people write letters; their houses burn down; they travel to Moscow to study at the university; they grieve because of the death of their loved ones; they argue and get old. They tell us that they prefer to be considered too proud rather than maintain relations with bad company. The Autocratic discourse explicitly posits the need to equate behaviour in the private and the public spheres because one is visible to God even in the most private circumstances, as quotations like (120) and (161) demonstrate.

This is the Orthodox Christian stance that befits the Holy-Rus doxa. In fact, the Civilized-World doxa was no less sure that the private sphere should be as elevated and subject to norm as the public sphere. It is not a coincidence that one of the (resented) objectives of Peter the Great was to reform Russian private life. see (92). As a synthesis of these two doxas, the Autocratic discourse could only present a vamished image of private life.

In comparison with Imperial and post-Soviet discourses, in the Soviet Communist discourse there was a particularly deep gulf between public and private, which was accompanied with bias in favour of the public. This bias is expressed to varying degrees in textbooks. Communist discourse textbooks spend most of their time praising the successes of the Soviet people in public fields as varous as the sciences, ballet, the conquest of cosmic space, the use of atomic energy for peaceful purposes and so on. As was already pointed out, Communist disiourse holds private life to be unproblematic. Here is some further evidence. 
Family dinners in the hungry years after the Second World War feature osetrina 'sturgeon', šci 'cabbage soup', kulebjaka 'meatpie', gus' 'goose', sladkij pirog 'sweet pie', moroženoe 'ice cream' and frukty 'fruit' (RMLR 1947, 234-235). Social services and health care are excellent. When Vasilij Nikolaevič feels pain in his legs, he goes to the hospital. He is delighted with his stay in the hospital: (260) Vasiliju Nikolaevicu [...] ponravilas' bol'nica. (RJaV 1976, 198)

'Vasilij Nikolaevic liked the hospital.'

Not coincidentally, this sentence was omitted in a later edition of the textbook (RJaV 1992, 356). The image of hospitals in the Dissident discourse is at variance:

(261) Glavnyj vrač rasporjadilsja o tom, čtoby Żannu položili v obsčuju palatu s pjatnadcat'ju drugimi bol'nymi. Kole ne udalos' ubedit' dežumuju medsestru, čtoby Žanne dali boleutoljajušcee, potomu čto glavnyj vrą̌ zapretil, čtoby bol'nym davali boleutoljajušcee po sredam. Kakaja-to ženščina umoljala, čtoby ej razrešili ostat'sja $v$ bol'nice s rebenkom, no glavnyj vrac byl neumolim. (AR 1980, 284)

'The head physician gave instructions that Żanna be put in a ward with fifteen other patients. Kolya didn't succeed in convincing the nurse on duty that Zanna should be given a painkiller, because the head physician banned the use of painkillers on Wednesdays. A woman was pleading to stay in the hospital with her child, but the head physician was implacable.'

In contrast to Communist discourse, the Dissident discourse elaborates on Soviet private life, introducing realistic information about living standards and everyday routine: communal apartments, queues, marketplaces, summer houses, children's daycare, quality of the roads and so on. In general, one of the most salient characteristics of the Bridging discourse is the openness of its private sphere to observation, precedented only by the Dissident discourse. We can see Russians in illustrations cheat during exams (Illustration 64), threaten their nagging wives with a fist (Illustration 65) or quarrel about access to the bathroom in a communal apartment (Illustration 66). We can also hear them use colloquial language, as in the caption to Illustration 65, something unthinkable previously. 
In Communist discourse, private time is devoted to various group activities and thus made practically indistinguishable from public time:

(262) Volodja i ego druz'ja inostrancy casto sobirajutsja vmeste. Oni zanimajutsja, slušajut muzyku ili razgovarivajut. I segodnja oni sobralis' $v$ komnate, gde živet Volodja. Snačala oni slušali po radio koncert "Pesni o mire i družbe". Vystupali sovetskie i incstrannye studenty. (URJa 1973, $1: 113)$.

'Volodja and his foreign friends often get together. They study, listen to music or talk. Today they gathered in Volodja's room. First they listened to a radio concert Songs about Peace and Friendship. Soviet and foreign students were singing.'

Students are featured in the same textbook visiting in groups various places, such as the kolkhoz Put' Il'ica 'Lenin's Path' near Moscow, or the Exhibition of the Achievements of Soviet Economy VDNX. They go for a hike in the wilderness and meet with workers from the Moscow plant Serp $i$ molot 'Sickle and Hammer'. This continues the tradition depicted in LRSDA 1933, 3031, where people divide their free time among various kružki 'study circles' in the club devoted to political literacy, radio, photography, music, theatre and - for foreigners working in the USSR - the Russian language. The characters in AR 1980 on the other hand try to avoid public activities like these as best as they can in correspondence with the usual practice of real-life Soviet citizens.

Russians in the post-Soviet textbooks have other concerns. They successfully overcome difficulties of byt 'daily routine', teaching readers in the process how to deal with such problems properly, should they arise:

(263) -Allo! Ėto gorničnaja? Zvonjat iz nomera 1265 . U menja ne rabotaet svet i net gorjacej vody.

-Zavtra budet rabozij.

-Kak zavtra? Ėto bezobrazie! Ja ne mogu celyj den' žit' bez sveta i vody! Ozen' prošu vas vse sdelat' segodnja!

-No segodnja voskresen'e. Rabocix net.

-Ešče raz povtorjaju: ja očen' prošu sdelat' vse segodnja ili pomenjat' mne nomer. Da, kstati. V nomere ožen' xolodno. Prošu vas prinesti obogrevatel'. -Ne volnujtes', ja postarajus' vse sdelat'. 
"'Hello! Is this the chambermaid? It's room 1265. There is no light and no hot water here."

"The plumber and the electrician will attend to it tomorrow."

"What d'you mean by 'tomorrow'? It's outrageous! I can't live a whole day without light and water! Please fix it today!"

"But today is Sunday. There are no people to fix it."

"I repeat again: I insist on fixing it today or else move me to another room. By the way, it is very cold in the room. Please bring me a heater."

"Don't worry. I'll do my very best."' (KK 2000, 116, English translation as in the original)

(264) -Vy poslednij $v$ moločnyj otdel?

-Da, no za mnoj zanimala (očered') devuška. Ona otošla.

-Xorošo.

Cherez pjat' minut.

-Vy (stoite) za mnoj? Ja otojdu na minutu.

-Da, konečno. (DGR 2000,69)

"'Are you the last in line for the milk section?"

"Yes, but there was a young woman, who was standing behind me. She stepped away."

"Okay."

Five minutes later.

"Are you in line behind me? I'll step away for a moment."

"Yes, of course."

The contribution of the Bridging discourse to the group/individual and public/private controversy has another dimension as well. RREG 1992 embraces emphatically the private perspective that one owes loyalty to one's closest associates and not to abstract principles or to society at large. This attitude springs from the focus on individual destinies rather than large abstract categories, that is, from giving priority to the individual and the private aspect of social life. Breach of loyalty is called predatel'stvo 'treason'. Reporting your peers to the superiors is not only morally wrong, it is also unrewarding:

(265) Nikakaja vysokaja ideja ne možet opravdat' predatel'stvo, a v osnove predatel'stva ležit malen'kaja kaplja zavisti. (RREG 1992, 159-160)

'No lofty idea can justify treason. At the base of treason lies a small drop of envy.' 
This is a stance the Bridging discourse inherited from the heterodox Dissident discourse. AR 1980's character Kolja thinks highly of his student group monitor because the latter is brave enough not to report students who have missed classes. Missing classes can lead to a temporary loss of scholarship (AR $1980,61,64)$. A Russian student visiting the Urited States is surprised to see that not only would the university administration encourage students to report on other students' plagiarism but also "snitching" would not even be stigmatized in student circles. Such behaviour is seen quite insightfully by the speaker as a manifestation of extreme individualism (LTL 1996, 51), or, as I would say rephrasing him, as a sign that American students, unlike their Russian counterparts, lack a distinct group identity. The orthodox Communist perspective on that, as illustrated by the famous story of the teenage boy Pavlik Morozov who turned his family in to the militia, prescribes similar actions. However, in the context of the Communist discourse they were always motivated by the need to place the interests of society before one's own.

Having seen the proximity of the Autocratic and the Communist discourses in regard to the public/private and the group/individual oppositions, we can start to appreciate the true proportions of the rupture between the Bridging discourse and its predecessors. If the Bridging discourse generously opens up the private lives and souls of Russians to the gaze of outsiders, there is a second-language textbook type that takes the opposite view on the appropriate ratio of public and private: the Cooped-Up Insider Model. It is exemplified by LR 1960 and SLR 1993. Characters in these textbooks are alert and buttoned up. They are concentrated and mobilized because they feel that unfriendly strangers are staring at them. Not coincidentally, one of the few clear-cut visual oppositions of Self (in this case decent and proper) and Other (in this case weird and frivolous) comes from SLR 1993 (see Illustration 43). On the other hand, they want to leave the best impression and this ambiguity makes them tightlipped. What is happening in the duša of their characters remains a mystery. 
These interchangeable characters keep as much as possible to the public sphere of life and avoid any personal touches. The buming desire to make sure that everything said remains valid under any circumstances produces generic and quasi-generic sentences like the following:

(266) Ja pojdu na koncert zavtra, esli budet pet' moj ljubimyj artist. 'I'll go to the concert tomorrow if my favourite singer will be singing.' (SLR 1993, 132, English translation as in the original)

(267) Zavtra v Moskve otkryvaetsja meždunarodnaja vystavka. (SLR 1993, 162)

'An international exhibition will open tomorrow in Moscow.'

(268) Včera v klube MGU byl izvestnyj pisatel'. Ran'še Sejla videla tol'ko portrety pisatelja. Sejla skazala pisatelju, żto ego znajut i ljubjat v Anglii. Ona sprosila pisatelja, byl li on v Anglii. Druz'ja Sejly tože poznakomilis' s pisatelem. Druz'ja dolgo potom razgovarivali o pisatele. (SLR 1993, 243 244)

'Yesterday a famous writer was at the club of the Moscow State University. Sheila had only seen portraits of the writer before. Sheila told the writer that people in England know him and like him. She asked the writer whether he had been in England. Sheila's friends also met the writer. Afterwards the friends had a long talk about the writer.'

(269) Turisty guljajut po ulicam i ploščadjam, bul'varam i parkam Moskvy. Turisty xodjat po muzejam Moskvy. Gidy rasskazyvajut turistam ob istorii stolicy. (SLR 1993, 286)

'Tourists walk along the streets, squares, boulevards and parks of Moscow. Tourists visit the Moscow museums. Guides tell the tourists the history of the capital.'

(270) Olimpijskie igry načalis' očen' toržestvenno. Na stadione pojavilsja lučšij sportsmen strany. On bežal po stadionu $s$ fakelom $v$ rukax. On nes Olimpijskij ogon'. Potom byl parad učastnikov Igr. Po stadionu šli junoši i devuški iz raznyx stran. Oni nesli flagi. Ėto byl parad molodosti, sily i krasoty. (SLR 1993, 324)

'The Olympic Games started very solemnly. The best athlete of the country appeared in the stadium. He was running with a torch in his hands. He was carrying the Olympic fire. Afterwards there was a parade of the participants 
in the games. Young men and women from different countries were walking in the stadium. They were carrying flags. This was a parade of youth, strength and beauty.'

(271) V SSSR bol'łaja zabota o studentax. Oni polučajut stipenđii, obక̌čežitija i deševoe pitanie. (LR I960, 126)

'In the USSR students are well taken care of. They receive scholarships and the right to reside in residence and buy inexpensive meals.'

This is as personal as it gets:

(272) Puškin - samyj lučšij russkij poèt. Ego stixi - moi samye ljubimye. Gor'kij - samyj izvestnyj sovetskij pisatel'. Ja očen' ljublju ego romany i rasskazy. A vy ljubite ego romany i rasskazy? (LR 1960, 91)

'Puskin is the best Russian poet. His poems are my favourite. Gor'kij is the best-known Soviet writer. I love his novels and shor stories very much. How about you? Do you like his novels and short stories?'

These mortified characters watch on TV a theatre play entitled Gorod na zare 'A City at Dawn' about the Soviet-built city Komsomol'sk, documentaries about the seven-year plan and Soviet sputniks and space ships, a musical show entitled Muzyka, pesni $i$ tancy narodov SSSR 'Music, Songs and Dances of the Peoples in the USSR', a sports show and the movie Sud 'ba celoveka 'A Person's Destiny' (LR 1960, 160). When they read the newspaper thiny years later they come across the following article titles: Novaja stancija metro otkryta 'A New Subway Station Has Been Opened', Zakončeno stroitel 'stvo ximičeskogo zavoda 'The Construction of the Chemical Plant Has Been Completed', Objazatel'stva po stroitel'stvu skol vypoleneny. 'The School Construction Projects Have Been Carried Out', Zapuščen novyj kosmičeskij korabl' 'A New Space Ship Has Been Launched'. Stroitel'stvo novogo avtomobil'nogo zavoda budet zakončeno čerez dva mesjaca 'The New Automobile Plant Will Be Ready in Two Months', Plan stroitel'stva novyx škol budet vypolenen polnost'ju 'The New School Construction Plan Will Be Implemented in Full' (SLR 1993, 366). This is evocative of the level on which information is exchanged in general. Readers are 
introduced to nondescript characters boasting as few identities as possible and pronouncing utterances of universal validity in the framework of the chosen discourse. In LR 1960 the favoured identities are citizenship, social class and profession:

(273) Inžener Žilin - graždanin SSSR. Moja sestra - graždanka SSSR. (LR $1960,44)$

'The engineer Žilin is a citizen of the USSR. My sister is a citizen of the USSR.'

(274) Ja rabočij. Vot naš cex. Zdes' cugun. (LR 1960, 47)

'I am a worker. This is our shop. There is cast iron here.'

(275) Sejčas den". Solnce svetit jarko. Kolxoz "Zarja" ubiraet urožaj. Rabotaet kombajn. Učitel’ Nikitin edet v kolxoz “Zarja”. (LR 1960, 59)

'Now it is day[time]. The sun is shining brightly. The collective farm Dawn is bringing in the harvest. A combine is working. The teacher Nikitin is going to the collective farm Dawn.'

(276) Inostrannye gosti - turisty - Casto poseščajut kolxoz "Novaja žizn". Priezd gostej-inostrancev raduet kolxoznikov. Oni pokazyvajut gostjam kolxoznye polja i fermy. Gostej interesujut kolxoznaja texnika, obrabotka zemli, kolxoznye fermy. Gosti teplo privetstvujut Geroev socialističeskogo truda. Kolxozniki s interesom besedujut s gostjami. Oni nadolgo soxranjajut pamjat' o gostjax. (LR 1960, 129)

'Foreign guests - tourists - often visit the collective farming complex New Life. The collective farmers enjoy the visits of the foreign guests. They show the collective fields and farms to the guests. The guests are interested in the farm machines, the cultivation of the land and the collective farms. The guests warmly greet the Heroes of socialist labour. ${ }^{35}$ The collective farmers animatedly converse with the guests. They will remember the guests for a long time.'

\footnotetext{
${ }^{35}$ Explained in the textbook in English as a title awarded to citizens of the USSR for outstanding deeds contributing to the development of the national economy, science or technique ${ }^{\circ}$ (LR 1960. 129).
} 
(277) Sovetskie ljudi postroili uže mnogo kanalov. Oni preobrazili mnogo pustyn'. Na meste pustyn' teper' rastet pక̌enica, ris, rastet xlopok i vinograd, $v$ sadax zelenye derev'ja. Na vetkax pojut pticy. Tam gde byli pustyni, voznikli novye goroda, sela $\mathbf{i}$ derevni, vyrosli zavody, fabriki, gidrostancii. Inžener Lukin rad, čto on tože budet stroit' kanal čerez pustynju. (LR 1960, 142)

'The Soviet people have already built many canals. They have transformed many deserts. Wheat, rice, cotton and grapes grow now in their place. In the gardens there are green trees. Birds sing in their branches. New cities, towns and villages have appeared where there used to be deserts. Plants, factories and hydroelectric power stations were built. The engineer Lukin is happy that he too will be building a canal across the desert.'

SLR 1993 allows for professional, kinship, national and gender identity. The most interesting of those is the latter. Apparently, the authors feel on safe ground here and they provide an uncensored picture of gender relations because it is indisputable to them. The presentation of gender relations is that traditional for Russia with men as the weak gender, as the following quotations and Illustration 67 demonstrate:

(278) - Moj muž teper' ne kurit.

- O! U nego sil'nyj xarakter!

- U nego? Ėto u menja sil'nyj xarakter! (SLR 1993, 107)

“"My husband quit smoking."

"Oh! He has a strong will!"

"Him? I am the one with the strong will!"

(279) - Mama, daj mne, požalujsta, pjat'desjat kopeek, - skazal syn materi.

- A mne - sto rublej, - skazala doč'.

- A mne, dorogaja, daj požalujsta, trista rublej, - skazal muž.

- C'to slucilos'? - sprosila mat'.

- Razve ty zabyla? Ved' u tebja segodnja den' roždenija. (SLR 1993, 175)

"'Mum, please give me fifty copecks," the son said to his mother.

"And to me a hundred roubles," the daughter said.

"And darling, please give me three hundred roubles," the husband said.

"What is the matter?" the mother asked.

"Have you forgotten? Today is your birthday." 
Furthermore, according to the authors one is well advised to avoid the topic of women's age if one wants to be safe (SLR 1993, 157, 297-298).

In contrast to the other second-language models, the Cooped-Up Insider Model shows preference for the generic members both in narrative and in image or, in other words, it aims to hide the individual behind the group. Moreover, these generic characters are presented as self-censored public figures with no visible duša. This model shares with others (such as the Narrow CommonGround and the Ethnocentric Outsider Models) the taste for reduced informativity, but it glosses over different, even diametrically opposed aspects.

This chapter demonstrated that the opposition of public and private, individual and group plays a significant role on two levels of this study: on the level of the SLL discursive formation and in the field of concomitance between it and the Identity discursive formation. The treatment of the group/individual and the public/private oppositions in Russian second-language textbooks provided the framework, in which one can set discursively apart the last remaining type of second-language textbook. These oppositions also highlighted one of the most distinctive features of the Bridging discourse against the background of all the others. 


\section{A Bird's-Eye View}

It is time now to return to the typology of Russian second-language textbooks presented on anthropological grounds in Table 2 and to redraw it according to discursive criteria. Now we shall look at it from the standpoint of the Identity discursive formation. In the history of Russia, identity has been structured according to several grids of specification (religion, civilization, ethnicity, citizenship, language and social class), whose salience has varied enormously from period to period. In Muscovy, religion was on the top of the hierarchy (the Holy-Rus Model of Self), to be replaced in early Imperial Russia by civilization (the Civilized-World Model of Self). The combined grids of ethnicity, citizenship and language came to the fore in late Imperial Russia and have remained a top priority ever since, despite the attempt to replace them with social class in the Soviet Union. The modem prevalence of ethnicity, citizenship and language stands out against their previous absence and serves as a ground for the delimitation of two periods: a premodem period based on silence and a modem one characterized by ethnicity-, citizenship- and language-based identity discourses in monologue. A very recent phenomenon, still in flux, is the appearance of dialogue among identity discourses, which points to the fragmentation of the grand identity narratives. This is what I called the GlobalVillage Mosaic Model of Self.

Depending on the level of intensity with which identity discourses are promoted among the outsiders represented by the readership of Russian secondlanguage textbooks, one can distinguish between a Proselytizing and a Broad Common-Ground approach. The premodern Holy-Rus and Civilized-World Models favour the Proselytizing approach. The modern models of Self may choose either, whereas the postmodern Global-Village Mosaic Model prefers the 
Broad Common-Ground approach. Thus we can see as a general tendency of the evolution of the Identity discursive formation the reduction of the fervour with which one's identity is enforced and the accompanying tolerance for alternative identities. In discursive terms the Proselytizing approach is characterized by directness and the Broad Common-Ground approach by indirectness. Directness manifests in the imperative and other forms of prescriptiveness, value judgements surfacing in the high frequency of axiological vocabulary and quasi-complete presentations of valuable wholes. The Broad Common-Ground approach avoids the didacticism immanent in the outspokenness of the Proselytizing approach by emphasizing summarizing symbols rather than valuable wholes and presenting general traits and tendencies in their reflection in individual events or persons.

Outside the Proselytizing and the Broad-Common Ground Models of Russian second-language textbooks, identity discourses get less attention. Pantial or skewed glimpses into identity discourses are provided in two types of textbooks: those subscribing to the Cross-Cultural Comparative and the CoopedUp Insider Models. The former chooses those aspects of Russian identity discourses that are meaningful from the perspective of the intended audience, while the latter limits the representation to generics in the public sphere.

Two further models, the Narrow Common-Ground and the Ethnocentric Outsider Models, are set apart in terms of the contrast between everyday talk and commentary. Both models ideally give a true picture of everyday talk combined with commentary that is deficient from the perspective of the Identity discursive formation. The former completely avoids references in the commentary to the field of concomitance between the SLL and the Identity discursive formations. The latter supplants the identity discourses of the target society with those of the author's society. 
Here we are finally at the end of the path. It is time now to look back at the landmarks that punctuate it and especially to determine its starting point and its direction.

I was playing with entitling this study Russia's Many Faces: Language and Identity in Russian Second-Language Textbooks until I realized that it was placing the wrong emphasis. It was focusing readers' attention on the multitude of images of Self that one can find in Russian second-language textbooks. But were these faces of Russia really new? Not to anybody who is acquainted with Russia. So if this book has its own word to say, it is not about the images of Self. They have been described before from different perspectives and what $I$ found in textbooks agrees with what others have found analysing other data, as it should. The most important difference between this study and ochers that have studied Russian identity is that this is a large-scale panorama that covers almost four centuries of Russian history, whereas the tendency as a rule has been to focus on identity discourses one at a time. This book can serve as an introduction to the fascinating oversized world of Russian identity discourses, but its significance lies somewhere else: it shows how the familiar images have been pieced together in a specific genre of books, and what discursive mechanisms serve to evoke these images.

My unit of analysis here was the discursive formation as defined by Michel Foucault. I looked closely at two: the SLL and the Identity discursive formations. The Identity discursive formation was explored only in the scope of its field of concomitance with the SLL discursive formation, and it is the latter's rules that predict to what extent identity discourses get included if at all. The focus on discursive formations alone justifies the attribution of this study to macropragmatics, which is the subfield of pragmatics dealing with language use in the broadest imaginable context (Mey 1998, 728-729). A plausible hypothesis that emerged in the process of empirical analysis and that needs further investigation is that discursive formations and their manifestation in commentary 
are human universals, or, in other words, that if there is a society, it necessarily has its universe of discourse. A future discipline of macropragmatic typology may be able to explore the patterns that human universes of discourse share and those that distinguish between them.

Stepping one rung down the ladder of abstraction, a blueprint for analysis on the level of the individual second-language textbook was the communicative situation as described by Roman Jakobson. The communicative situation brings together the participants in the communicative act (authors and audience) with the message (second-language textbook) and highlights their mutual interdependence.

Semiotics provided the unified framework for analysis of concepts that manifest themselves not only in narrative but also in image. The classification of signs into generic and specific with the further subdivision of the latter into marked and unmarked (exemplary and ordinary) allowed the isomorphic presentation of various levels: from the sources of authority in terms of speaking subject to the narrative and visual presentation of Self as a holder of identities in textbooks. Furthermore, the semiotic vantage point made it possible to organize the concepts of the Identity discursive formation into a hierarchy of valuable wholes and their metaphorical and metonymical summarizing symbols.

And finally, key Russian words were subjected to semantic analysis in context along the lines of the contemporary trend towards the study of the naïve "model of the world" increasingly popular in the Slavic countries.

If I am to apply the expertise obtained in the course of this study to the practice of writing Russian second-language textbooks, my recommendation to insider authors would be to choose the Broad Common-Ground Model, perhaps with a preference for the constants of Russian culture at the beginners' level and a switch to a pluralist approach at the more advanced levels. Outsider authors are stuck with the Cross-Cultural Comparative Model, in which one should perhaps strive to embed the same Russian focus: "timeless" Russianness at the early 
stages and an introduction to the range of competing opinions later on. The more the private life, dreams and musings of the Russian-speaking subject get into second-language textbooks, the better the chances that interested outsiders will be able to cross the cultural and linguistic barrier. In order to survive, today's global world needs the empathy of as many competent outsiders as possible. 


\section{Bibliography}

\section{Sources $^{1}$}

AG 1731

Alekseev 1951

AR 1980

AR 1992

BKSO
Adodurov, V. E. Anfangs-Gründe der Russischen Sprache. St. Petersburg: Gedr. in der Kayserl. Acad. der Wissenschafften Buchdruckerey, 1731 [reprinted in Unbegaun 1969].

Alekseev, M. P. “Kniga russkogo jazyka” T. Šrove $1546 \mathrm{~g}$. i ee avtor. In Pamjati akademika L'va Vladimiroviča Sčerby (1880-1944). Leningrad: Izdatel'stvo Leningradskogo gosudarstvennogo universiteta im. A. A. Żdanova, 1951, 103-112.

Nakhimovsky, Alexander and Richard Leed. Advanced Russian. Columbus, Ohio: Slavica Publishers, Inc., 1980.

Bejker, A. G. [A. G. Baker] \& A. N. Ščukin. Amerikanec v Rossii. Russkij jazyk v dialogax $i$ monologax. Moskva: Russkij jazyk, 1992.

Bol’šaja kartoteka Slovamogo otdela Instituta lingvistižcskix issledovanij RAN (St. Petersburg). The year in brackets after the name of the author refers to the edition excerpted for the dutabase, which may or may not coincide with the time of first publication.

Bolek, Chodurska, Fałowski \& Kunińska 1997

Bolek, Anna, Halina Chodurska, Adam Fałowski \& Jolanta Kunińska. "Einn Russisch Buch" Thomasa Schrouego. Slownik i rozmowki rosyjsko-niemieckie z XVI wieku. Część II. Transliteracja tckstu. Indeks

\footnotetext{
'The textbroks which I have rot had the upportunity to consult de visu are marked with an asterisk.
} 
BR 1981

*BUYR 1933

CR 1948

CRAM 1961

CRR 1997

Dal’ $1880-1882$

DD 1902

DDE் 1994

DDP 1995 wyrazów i form rosyjskich. Kraków: Wydawnictwo Bohdan Grell, 1997.

Leed, Richard, Alexander Nakhimovsky \& Alice Nakhimovsky. Beginning Russian. Vol. 1.

Columbus, Ohio: Slavica Publishers, Inc., 1981.

Semeonoff, Anna Herring. Brush up Your Russian. New York: McKay, 1933.

Znamensky, George A. Conversational Russian. Boston: Ginn and Company, 1948.

Zenkovsky, Serge A. Conversational Russian for the American Student. Englewood Cliffs, N.J.: Prentice-Hall, 1961.

Kataeva, M. B., I. A. Protopopova, Z. P. Sergienko, Ju A. Vysokov, O.A. Eremina, N. Ju. Kuzenkova \& A. F. Černičenko. Citaem o Rossii po-russki. Izdanie 2-e, ispravlennoe i dopolennoe. SanktPeterburg: Zaltoust, 1997.

Dal', V. I. Tolkovyj slovar' živogo velikorusskogo jazyka. Vtoroe izdanie, ispravlennoe i znacitel'no umnožennoe po rukopisi avtora. Moskva, S.Peterburg: M. O. Vol'f, 1880-1882 [Reprint Moskva: Russkij jazyk, 1978-1980].

Andreev, N. Detskij drug. Rukovodstvo k obučeniju russkomu jazyku v tex skolax, v kotoryx deti pri postuplenii ne umejut govorit' po-russki. C. II. Pervaja posle azbuki kniga dlja ctenija. II-oe ispravlennoe $\mathrm{i}$ dopolnennoe izdanie. Riga: Izdanie Ionk i Polievskago, 1902.

Lixačeva, O. V., N. G. Gruzdeva, E. M. Vinokurceva, A. N. Frolova, L. G. D'jakova, L. Z. Mazina \& N. S. Vlasova. Den' za dnem. Russkij jazyk. Uc̈ebnik dlja inostrannyx učašcixsja. I. Ekspress. Vyp. 1-6 + A-B Moskva: ILBI, Samarskij dom pecati, 1994.

Vlasova, N. S., N. G. Gruzdeva, O. V. Lixačeva, Ė. M. Vinokurceva, A. N. Frolova \& L. G. D'jakova. 
DGR 2000

DKNJR 1938

Dobroljubov 1962 [1859]

Doroszewski 1965

*DR 1749

DRS 1629

Duliðenko 1999

E 1938
Den' za dnem. Russkij jazyk. Učebnik dlja inostrannyx učaščixsja. II. Panorama. Vyp. 1-9. Moskva: ILBI, Samarskij dom pecati, 1995.

Glazunova, O. I. Davajte govorit' po-russki. UČebnoe posobie po russkomu jazyku dlja inostrancev. 3-e izdanie, ispravlennoe. Moskva: Russkij jazyk, 2000.

Kułakowski, S. Druga ksiqżka do nauki języka rosyjskiego. Lwów, Warszawa: Książnica Atlas, 1938.

Dobroljubov, N. A. Praktischer leitfaden zum Elriernen der russischen Sprache, berbeited von I. Pihlemann, Lehrer der russischen Sprache am Gymnasium zu Reval. Reval, 1857, in-8, $\mathrm{X}+272+58$. In Dobroljubov, N. A. Sobranie socinenij. Tom Cetvertyj. Moskva, Leningrad: Gosudarstvennoe izdatel'stvo xudožestvennoj literatury, 1962, 417-421.

Doroszewski, Witold (ed.). Slownik jezyku polskiego. T. 7. Warszawa: Państwowe wydawnictwo naukowe, 1965.

Platz, Georg Philipp. Domašnie razgovory. SanktPeterburg: Peč. pri Imp. Akad. nauk, 1749.

Günther. Erika. Das deutsch-russische Sprachbuch des Heinrich Newenburgk von 1629: Einführung, sprachliche Analysen. Text, Faksimile. Frankfurt: Peter Lang, 1999.

Duli Xenko, Aleksandr. D. Ėnosociolingvistika "Perestrojki" v SSSR. Antologija zapeciatlennogo vremeni. München: Otto Sagner, 1999. [Slavistische Beiträge, Bd. 378].

Katcer, Ju. M. et al. English. Uëebnik anglijskogo jazyka dlja vuzov $i$ vtuzov. Moskva - Leningrad: NKTP SSSR, 1938. 
ERB 1546

ERB s.a.

Falowski 1996

*FRR 1933

FSR s.a. [1918?]

G 1998-1999

GMRF 1724

Gor'kij 1968

GR 1696

GRJa 1873
Falowski, A. \& W. Witkowski. "Einn Russisch Buch" Thomasa Schrouego. Slownik i rozmówki rosyjsko-niemieckie z XVI wieku. Cz. I. Wstęp. Fotokopie. Kraków: Universitas, 1992.

Fałowski, Adam. "Ein Rusch Boeck...". Ein Russisch-deutsches anonymes Wörter-und Gesprächsbuch alis dem XVI. Jahrhundert. Köln, Weimar, Wien: Böhlau, 1994 [Bausteine zur slavischen Philologie und Kulturgeschichte. Reihe B: Editionen, Neue Folge Band 3 (18)].

Fałowski, Adam. “Ein Rusch Boeck...". Rosyjskoniemiecki anonimowy slownik i rozmówki z XVI wieku. Analiza językowa. Kraków: Universitas, 1996.

Semeonoff, Anna Herring. A First Russian Reader. London: Dent, 1933.

Solomonoff, J. First Steps in Russian. London: Kegan Paul, Trench, Trubner \& Co., Ldd., [1918?].

Robin, Richard, Joanna Robin \& Kathryn Henry. Golosa: A Basic Course in Russian. Books 1-2. Second Edition. Upper Saddle River, New Jersey: Prentice Hall, 1998-1999.

Sohier, Jean. Grammaire et Methode Russes et Françoises. 1724. Faksimil'noe izdanie pod redakciej is predisloviem B. A. Uspenskogo. I-II. München: Verlag Otto Sagner, 1987.

Gor'kij, M. Polnoe sobranie sočinenij. Xudožestvennye proizvedenija $\nu$ dvadcati pjati tomax. T. 1. Moskva: Nauka, 1968.

Unbegaun, B. O. Henrici Wilhelmi Ludolfi Grammatica Russica, Oxonii, A.D. MDCXCVI. Oxford: Clarendon Press, 1959.

[Radlov, V.] Grammatika russkogo jazyka. sostavlennaja dlja tatar vostočnoj Rossii. Cast' $I$. Etimologija. Kazan': Universitetskaja tipografija, 1873. 
GRJaI 2000

GRS 1704

GTJa 1835

HK 1789

HRGS s. a. [1916?]

HRGS s. a. [1937?]

Ihl-Behrend \& Tretjakow 1981

Wolke, Chr. Hr. Hundert Kupferstiche von dem berïhmten Künstler Daniel Chodowiecki zu Berlin gezeichnet, zur leichtern und angenehmem Enwerbung der Sprachen- und Sachen-Kenntnisse mit einer französichem deutschen und lateinischen Beschreibung, begleitet. St. Petersburg: [no publisher], 1789.

Hugo, Charles. Hugo's Russian grammar simplified; the only real self-instructor; exercises. key and vocabularies, with the pronunciation of every word exactly imitated. Philadelphia: David McKay, [1916?].

Hugo's Russian grammar simplified; the only real self-instructor; exercises, key and vocabularies, with the pronunciation of every word exactly imitated. "Standird" edition. Revised and rewritten. Philadelphia: David McKay company, [1937?].

IhI-Behrend, Luise \& Pirjo Tretjakow. Lehr- und Lemmittel für Russisten. Bibliographie und Rezensionen. Teil I. Westliche Ausgaben. Hamburg: Helmut Buske, 1981.

Ihl-Behrend \& Schwalbe 1982 
Il'minskij 1873

Il'f \& Petrov 1995a

Il'f \& Petrov 1995b

KC 1888

KČU 1878-9

KK 2000
Ihl-Behrend, Luise \& Irmgard Schwalbe. Lehr- und Lemmittel für Russisten. Bibliographie und Rezensionen. Teil 2. Östliche Ausgaben. Hamburg: Helmut Buske, 1982.

Il'minskij, N. Novyja učebnyja rukovodstva dlja Tatar-Magometan (Bilik - Xisablyk - Gramatika russkago jazyka, cilja tatar vostočnoj Rossii. Tillik. Cast' I) G. Radlova. Zhurnal Ministerstva narodnago prosveščenija, 167, 1973, otdel IV, 370374.

Il'f. Il'ja \& Evgenij Petrov. Dvenadcat' stul'ev. Sreglov, Ju. K. Kommentarii k romanu. Moskva: Panorama, 1995.

Il'f, Il'ja \& Evgenij Petrov. Zolotoj telenok. Ščglov, Ju. K. Kommentarii k romanu. Moskva: Panorama. 1995.

Meves, D. V. Kniga dlja čtenija i praktičeskix uprainenij v russkom jazyke. Rukovodstvo dlja narodnyx škol s russko-latyšskim slovarem. Izdanie vtoroe, dopolnennoe $i$ ispravlennoe. Riga: Izdanie N. Kimmelja, 1888.

Kozin, E. Kniga dlja čtenija $i$ upražnenij v russkom jazyke. C. 1-2. Mitava: Tipografija Zislaka. 18781879.

Akišina, T. E. \& T. P. Skorikova. Kontakry dlja kontraktov. Russkij jazyk v delovom obšenii. Moskva: Russkij jazyk. Kursy, 2000.

Korsak, Levitin \& Mozgunova 1994

Korsak, L. V., M. N. Levitin \& G. N. Mozgunova. Sud by nacional 'nyx men 'šinstv na Smolenšcine (1918-1938 g.g.). Dokumenty i materialy. Smolensk: Arxivnoe upravlenie Administracii Smolenskoj oblasti; Gosudarstvennyj arxiv Smolenskoj oblasti, 1994.

KRS s.a. [1890-1899?]

Munassewitsch, B. Die Kunst die Russische Sprache durch Selbstumterricht schnell und lici.lit zu erlemen. Theoretisch-praktische Sprikchlchre für 
Levašov 1997

LGMSR 1607

LR 1960

LRSDA 1933

LTL 1996

MD 1880
Deutsche auf grammatischer Grundlage und mit phonetischer Aussprachebezeichnung; mit zahlreichen Übungsaufgaben, sowie mit einer Chrestomathie mit durchgängiger Accentuation und interlinearer deutscher Übersetzung, samt einem kurzgefassten deutsch-russischen Wörterbuche.

Vierte Auflage. Wien. Pest. Leipzig: A. Hartleben's Verlag, [1890-1899?].

Levašov, E. A. Novye slova i značenija. Slovar'spravoćnik po materialam pressy i literatury 1980-x godov. Sankt-Peterburg: Dmitrij Bulanin, 1997.

Hammerich, L. L., Roman Jakobson, Elizabeth van Schoneveld, T. Starck and Ad. Stender-Petersen (eds.) Tönnies Fenne's Low German Manual of Spoken Russian. Vol. I. Facsimile Copy.

Copenhagen: Bianco Lunos Bogtrykkeri A-S, 1961; Hammerich, L. L. and Roman Jakobson (eds.). With the assistance of Karen Bente Goudsmith, Elizabeth van Schoneveld and Adolf Stender-Petersen. Tönnies Fenne's Low German Manual of Spoken Russian. Vol. II. Transliteration and Translation. Copenhagen: Royal Danish Academy of Sciences and Letters, 1970.

Potapova, Nina. Learning Russian. Moscow: Foreign Languages Publishing House, 1960.

Basiljewitsch, L. I., S. M. Frumkina \& W. N. Klujewa. Lehrbuch der russischen Sprache für deutsche Arbeiter. 1. Lehrjahr. Moskau:

Verlagsgenossenschaft ausländischer Arbeiter in der UdSSR, 1933.

Tall, Emily \& Valentina Vlasikova. Let's Talk about Life! New York - Chichester - Brisbane Toronto - Singapore: John Wiley \& Sons, Inc., 1996.

Solomonovskij, I. Material dlja diktanta $i$ drugix grammatičeskix uprażnenij, podobrannyj $i$ raspolożennyj primenitel 'no $k$ uslovijam prepodavanija russkogo jazyka v ućebnyx 
MG 1706

MLR 1811

MLR 1938

Mokienko \& Nikitina 1998

MPLR 1952

MPMR 1998

N 1996-1997

NDRG 1792

*NDU 1885 zavedenijax Varšavskogo učebnogo okrugal. Solomonovskim. Varšava: Pečatnja Paevskogo, 1880.

Kopijewitz, Elias. Manuductio on Grammaticam in Sclavonico Rosseanam seu Moscoviticam. Stolzenberg: Christianus Philippus Goltzius, 1706 [reprinted in Unbegaun 1969].

Languen, Jacques. Manuel de la langue russe, à l'usage des étrangers; suivi d'un précis historique sur la Littérature russe. A Mitau: Chez Jean Frédéric Steffenhagen et fils, Imprimeurs, 1811.

Afanasiev, A. \& I. Šapošnikov. Manual de lengua rusa. Moscú: Ediciones cooperativas de los obreros extranjeros en la U.R.S.S., I-II, 1938.

Mokienko, V. M. \& T. G. Nikitina. Tolkovyj slovar' jazyka Sovdepii. Sankt-Peterburg: Folio-Press, 1998.

Manual popular de limbă rusă pentru uzul cursurilor populare.Ciclul I. [Bucureşti]: Editura Arlus „Cartea rusă”, 1952.

Pisarčik, N. Ju. \& Ju E. Proxorov. My poxoži, no my raznye. Sankt-Peterburg: Zlatoust. 1998.

Lubensky, Sophia. Gerard L. Ervin \& Donald K. Jarvis. Nacalo. When in Russia... Books 1-2. New York: The McGraw-Hill Companies, Inc., 19961997.

Vegelin, Ioann Filipp. Novye nemeckie i rossijskie razgovory, razdelennye na 130 urokov. dlja upotreblenija junošestvu $i$ vsem nainajuščim ucit 'sja sim jazykam. Moskva: Tipografija Selivanovskago i tovarišca, 1792.

Levik, Ju. Novyj detskij učitel': naćal 'nyj učebnik russkago jazyka dlja evreev. Varšava: Jozef Unterhendler, 1885. 
Neiswender 1962

NERD 1822

NRG 1788

Nikolic 1848

NIR 2000

NORJa 1839

NPEM 1900

NRG 1935

NREL 1811
Neiswender, Rosemary. Guide to Russian Reference and Language Aids. New York: Special Libraries Association, 1962 [=SLA Bibliography No. 4].

New English and Russian Dialogues, Divided into 130 Lessons, for the Use of Youth \& of All Those That Begin to Learn the Two Languages. In the manner of J. Ph. Wegelin. Moskva: Tipografija S. Selivanovskago, 1822.

A[staxov], I[van]. Novaja rossijskaja grammatika. Sankt-Peterburg: [Tip. Mor. kadet. Korpusa], 1788.

Nikolič, I. Nečto o sovremennyx trebovanijax kasatel 'no sostavlenija xrestomatij po casti russkago jazyka dlja učilišč Ostzejskago kraja. Mitava: Tipografija I.F.Steffengagena i syna, 1848.

Anikina, M. N. Načinaem izučat' russkij. V Rossiju s ljubov'ju. Moskva: Russkij jazyk, 2000.

Rklickij, Vasilij V. Načal'nyja osnovanija Russkago jazyka dlja načinajuśčix učit 'sja poRusshi ili legčajš̀j sposob naučit 'sja čitat 'i pisat' po-Russki, i perevodit' s Russkago jazyka na Pol'skij. Izdanie vtoroe. Varšava: Tipografija M. Xmelevskago, 1839.

Alexandrow, F. A New Practical and Easy Method of Learning the Russian Language Including Rules for Pronunciation. Exercises, Reading Lessons, Lists of Useful Words, Dialogues, etc. etc. New Edition. London: Hachette and Company, 1900.

Semeonoff, Anna. A New Russian Grammar in Two Parts: Written in Accordance with the New Orhography and the Stabilised Grammar Confirmed by the Commissariat of Education of R.S.F.S.R. 1933. Reprinted with corrections. London, New York: J. M. Dent, E. P. Dutton, 1935.

Tappe, August Wilhelm. Neues Russisches Elementar-Lesebuch, für Deutsche, enthaltend: Sentenzen und Maximen. Fabeln. Anecdoten. eine 
NRG 1956

NSRJa 1875

OPUK 1835

ORTPG 1825

Ožegov 1984

P 21996

PFK 1995

PGRL 1827 geographisch-statistische Uebersicht Rußlands, eine Komedie im Auszuge und Bruchstücke aus Karamsins Schrifien. Durchaus accentuint, nebst Uebersetzungen. Wönern und Phraseologien, als zweite Abtheilung der russischen Sprachlehre. Zweite verbesserte Auflage. St. Petersburg: beim Verfasser, 1811.

Semeonoff, Anna H. A New Russian Grammar in Two Parts. Fourth (revised) edition. London, New York: E. P. Dutton \& Co. Inc., 1956.

Vanel', G. Novyj samoučitel' russkogo jazyka dlja evreev. Vilna: Tipografija M.R.Romma, 1875.

M.D.I. Opvt polnago učebnago kursa russkoj grammatiki, dija prepodavanija russkim $i$ inostrancam. Moskva: Universitetskaja tipografija, 1835.

Šliter, Karl. Opyt rossijskoj teoretičeskopraktičeskoj grammatiki s primerami dlja perevoda s nemckogo na russkij jazyk po pravilam. pomeščennym v načale każdogo paragrafa. St. Petersburg: N. Gretch, 1825.

Ožegov, S. I. Slovar' russkogo jazyka. Izdanie pjatnadcatoe, stereotipnoe. Moskva: Russkij jazyk, 1984.

Kostina, I. S., N. N. Aleksandrova, T. I.

Aleksandrova \& E. B. Bogoslovskaja. Perspektiva. Osnovnaja Cast'. Vypusk 2. Sankt-Peterburg:

Zlatoust, 1996.

Kostina, I. S., N. N. Aleksandrova, T. I.

Aleksandrova \& E. B. Bogoslovskaja. Perspektiva. Foneticeskij kurs. Sankt-Peterburg: Zlatoust, 1995.

Heard, James. A Practical Grammar of the Russian Language. St. Petersburg: Tipografija Departamenta Narodnago Prosveščenija, 1827. (= Gerd Ja.

Praktičeskaja grammatika rossijskogo jazyka dlja angličan. C. 1-2. Sankt-Peterburg: lzdill Sienskij. 1827) 
PKORJa 1913

*PKORJa 1915

*PKRJa 1847

*PL 1857

PPU 1899

PRG 1938

PRGN 1853

PRIRJa 1878

PZRJa 1868

R 2000
Mixeev, I. S. Pervaja kniga dlja obučenija russkomu jazyku v inorodčeskix školax. Devjatoe izdanie. Kazan': Central'naja tipografija, 1913.

Mixeev, I. S. Pervaja kniga dlja obučenija russkomu jazyku v inorodčeskix školax. Tokyo: Matsamura Sanshodo, 1915.

[I. S.] Praktičeskij kurs russkogo jazyka. sostavlennyj po rukovodstvam Greča, Vostokova, Plaksina. Polovcova. Ivanova i drugix dlja prepodavanija $v$ nizšix $i$ srednix učebnyx zavedenijax russkim i inostrancam. SanktPeterburg: Tipografija Akademii nauk, 1847.

Pihlemann, I. Praktischer Leitfaden zum Erlernen der russischen Sprache. Reval: F. Kluge, 1859.

Praktičeskie pervonačal 'nye uroki russkogo jazyka dlja baškir. Kazan': Tipografija V, Ključnikova, 1899.

Kolni-Balozky, J. A Progressive Russian Grammar. An Up-To-Date Grammar for General Use Having the New Orthography and the Simplified Forms of Grammar Confirmed by the Commissariat of Education of the R.S.F.S.R. London: Sir Isaac Pitman \& Sons, 1938.

Serno-Solov'evic, A. Praktičeskaja russkaja grammatika dlja nemcev. Revel': Franz Kluge, 1853.

Kozin, E. Praktičeskoe rukovodstvo dlja mladšix klassov srednix učebnyx zavedenij Pribaltijskago kraja. Libava, 1878.

Grušeckij, V. Pervonačal'noe znakomstvo s russkim jazykom. Vtoroe, uveličennoe izdanie. Varšava: Tipografija Ivana Javorskago, 1868.

Rodimkina, Alla \& Neil Landsman. Rossija 2000. Sankt-Peterburg: Zlatoust, 2000. 
RAPP 1898

RB 1999

REB 1923

REB 1938

RESW 1933

REW 2000

RES

RG 1750

*RGEM 1876
Karagadaev, I. S. Russkaja azbuka s pravilami proiznošenija dlja inorodcev voobšće i tuzemcev Kavkaza v castnosti. Cerkassy: Parovaja TipoLitografija Š. Godiodskago, 1898.

Ovsiyenko, Y. G. Russian for Beginners. Seventh edition, revised. Moscow: Russky Yazyk Publishers, 1999.

Marnitz, L. v. Russisches Elementarbuch mit Hinweisen und seine Grammatik. Siebente verbesserte Auflage. Leipzig: Verlag von Raimund Gerhard, 1923.

Marnitz, L. v. Russisches Elementarbuch. Verkürzte Nebenausgabe B in neuer Rechtschreibung. Zehnte verbesserte Auflage. Bearbeitet von Dr. Edgar Spinkler. Leipzig: Verlag von Raimund Gerhard, 1938.

Smimitsky, A. I., M. A. Solonino, P. P. Sveshnikov \& I. A. Figurovsky. Russian for English Speaking Workers. Firsi Year Course. Moscow: Co-operative Publishing Society of Foreign Workers in the USSR, 1933.

Useinova, Gulnara. Russian in an Easy Way. St. Petersburg: Zlatoust, 2000.

Proxorov, A. M. (ed.-in-chief). Rossijskij enciklopedičeskij slovar'. Kn. 1-2. Moskva:

Bol’'̌aja Rossijskaja ènciklopedija, 2000-2001.

Groening, Michael. Rossijskaja grammatika. Stockholm: Tryckt uti Konigl. Tryckerier, 1750 [reprinted in Unbegaun 1969].

Russkaja grammatika dlja evrejskix melamedov. Sostavlennaja po programme, izdannoj Ministerstvom narodnogo prosveščenija dlja želajuščix polučit' pravo i zvanie domašnix učitelej. Sankı-Peterburg: Tip. Cederbauma i Gel'denbljuma. 1876. 
RHG 1635-1648

RJa 1952

RJaIS 1974

RJaSI 1970

RJaV 1976

RJaV 1992

RJaV 1995

RKG 1898

RKG 1931

RM 1901
Sørensen, H. C. Ein Russisches Handschrifilishes Gesprächbuch aus dem 17. Jahrhundert.

København: Aarhuus Stiftsbogtrykkerie [Historiskfilosofiske Meddelelser udgivet af Det Kongelige Danske Videnskabernes Selskab, Bind 39, nr. 8], 1962.

Tagamlickaja, G. \& A. Davydova. Russkij jazyk. Ucebnik dlja V klassa srednej školy. Sofija:

Narodna prosveta, 1952.

Kostomarov, V. G., V. I. Polovnikova \& L. N. Švedova. Russkij jazyk dlja inostrannyx studentov. Moskva: Russkij jazyk, 1974.

Venediktova, N. K. \& G. G. Gorodilova. Russkij jazyk dlja studentov inostrancev. Moskva: Vysకaja skola, 1970.

Stepanova, E., Z. Ievleva \& L. Trušina. Russkij jazyk dlja vsex. Pod redakciej V. Kostomarova. 3-e izdanie. Moskva: Russkij jazyk, 1976.

Stepanova. E., Z. Ievleva, L. Trušina \& R. L. Baker. Russkij jazyk dlja vsex. Pod redakciej V.

Kostomarova. 6-oe izdanie. Moskva: Russkij jazyk, 1992.

Slavkin. V. Russkij jazyk dlja vsex. Teksty L. Kašinskoj. Moskva: Drofa - Slovo, 1995.

Fuchs, Paul. Russische Konversations-Grammatik zum Schul-, Privat- und Selbstunterricht. Dritte Auflage bearbeited von Aug. Adolf Naht. Heidelberg: J. Groos, 1898.

Fuchs, Paul. Russische Konversations-Grammatik zum Schul-, Privat- und Selbstunterricht. Zehnte Auflage neubearbeitet von Dr. Nicolai v. Bubnoff. Heidelberg: J. Groos, 1931.

Davis. I. Rodnoj mir. Kniga dlja obučenija russkomu jazyku v inorodžcskix učiliščax. Cast' 
RM 1904

RP [1978?]

RMLR 1947

RPURU 1869

RR I 1914

RR III 1914

RR 2002 pervaja. Azbuka i pervaja posle azbuki kniga dlja ctenija. Riga: Izdanie K. G. Zixmana, 1901.

Davis, I. Rodnoj mir. Kniga dlja obučenija russkomu jazyku v inoroďeskix ucilišcax. Cast' tret'ja. Tret'ja posle azbuki kniga dlja čtenija. Riga: Izdanie K. G. Zixmana, 1904.

Malyšev, G. G. Russkie padeži. Komplekt učebnyx nagljadnyx materialov. Moskva: Russkij jazyk, [1978?].

Potapova, Nina. Le russe. Manuel de la langue russe a l'usage des Français. Deuxième édition. Moscou: Éditions en langues étrangères, 1947.

Ter-Akopov, N. Rukovodstvo k praktičeskomu izučeniju russkogo jazyka. Tiflis: Tipografija Épfiadžianca, 1869.

Vol'per, M. Russkaja reč'. Učebnoe rukovodstvo, primenennoe $\mathbf{k}$ obučeniju nusskomu jazyku tex detej, kotoryja pri postuplenii $v$ skolu ne umejut govorit' po-russki. 64-e izdanie. Cast' I. Bukvar'. S. Peterburg: Parovaja Skoropecatnja M. M. Gutzaca, 1914.

Vol'per, M. Russkaja reč'. Ucebnoe rukovodstvo, primenennoe $k$ obučeniju russkomu jazyku tex detej, kotoryja pri postuplenii $v$ §kolu ne umejut govorit' po-russki. So mnogimi risunkami. Cast' III. Kniga dlja čtenija. 33-e izdanie, perepečatannoe bez peremen s 32-go, soveršenno pererabotannago i znacitel'no dopolnennago, izdanija. S. Peterburg: Parovaja Skoropecatnja M. M. Gutzaca, 1914.

Kagan, Olga, Tatiana Akishina \& Richard Robin. Russian for Russians, Bloomington, Indiana: Slavica, 2002.

Alekseyeva, Natasha, Elza Ivanova \& Natasha Defye. Russian Review and Expansion Grammur. Munir Sendich, Michigan State University, 1992. 
RRG 1827

RRJa 1877

RS I 1896

RS I 1908

RS II 1898

RS II 1908

RS III 1898

RS III 1907
Marcella, S. Rossijsko-rumynskaja grammatika. Kn. 1-2. Sanktpeterburg: Tipografija Departamenta narodnogo presveščenija, 1827.

L.S.A.D. Rukovodstvo russkogo jazyka dlja latyšskogo junošestva. sostavlennoe po konkursu L.S.A.D. Riga: Tipografija Platesa, 1877.

Grigor'ev, L. Russkoe slovo. Rukovodstvo dlja obučenija russkomu jazyku $v$ tex కkolax, $v$ kotoryx deti pri postuplenii ne umejut govorit' po-russki. Vypusk pervyj: Bukvar'. 3-'e ispravlennoe i dopolnennoe izdanie. Riga: Izdanie K. G. Zixmana, 1896.

Grigor'ev, L. Russkoe slovo. Rukovodstvo k obučeniju russkomu jazyku v tex školax, v kotoryx deti pri postuplenii ne umejut govorit' po-russki. Vypusk pervyj: Bukvar'. 18-oe izdanie. Riga: Izdanie K. G. Zixmana, 1908.

Grigor'ev, L.\& B. Olenin Russkoe slovo. Rukovodstvo dlja obučenija russkomu jazyku v tex skolax, $v$ kotoryx deti pri postuplenii ne umejut govorit' po-russki. Vypusk vtoroj. 3-'e izdanie, ispravlennoe. Riga: Izdanie K. G. Zixmana, 1898.

Grigor'ev, L.\& B. Olenin Russkoe slovo. Kniga dlja klassnago čtenija. Rukovodstvo $k$ obučeniju russkomu jazyku $v$ tex školax, $v$ kotoryx deti pri postuplenii ne umejut govorit' po-russki. Vypusk vtoroj. 14-oe izdanie. Riga: Izdanie K. G. Zixmana. 1908.

Grigor'ev, L.\& B. Olenin. Russkoe slovo. Rukovodstvo dlja obučenija russkomu jazyku $v$ tex Skolax, $v$ kotoryx deti pri postuplenii ne umejut govorit' po-russki. Vypusk tretij. 3-'e izdanie, ispravlennoe i dopolnennoe. Riga: Izdanie K. G. Zixmana, 1898.

Grigor'ev, L.\& B. Olenin. Russkoe slovo. Kniga dlja klassnago čtenija. Rukovodstvo k obučeniju 
RS 1899

RSC 1940

RSL 1773

*RSL 1789

Rodde, Jacob. Russische Sprachlehre. Riga, Lipsiae: Bey Johann Friedrich Harknoch; Ex officina Breitkopfiana, 1789.

RST 1985

Baranova, N., R. Brecht, D. Davidson \& N. Kostromina. Russian. Stage Two. Moscow: Russky Yazyk, 1985.

RT 1935

Smimitsky, A. I. \& P. P. Sveshnikov. Russian Textbook. Elementary Course. Moscow: Cooperative Publishing Society of Foreign Workers in the USSR, 1935.

RT 2000

Rodimkina, Alla, Zoya Riley \& Neil Landsman. Russia Today. 3-rd edition. St. Peteresburg: Zlatoust, 2000.

RTRL 1945

Potapova. Nina. Russian. Textbook of the Russian Language for English-Speaking People. Part I. Moscow: Foregn Languages Publishing House, 1945.

RU 1902

Berlic, M. Đ. Russkij ućebnik. Prisposobil k russkomu jazyku L. L. Beitfus. Cetvertoe izdanie. Berlin, N'ju Jork, Pariž, London, Kopengagen. S. 
RU 1909

RX 1848

RX 1872

RX 1880

${ }^{*} \mathrm{RX} 1889$

RX 1894

SLR 1993

SRPJa 1838

SRJa 1869
Peterburg, Moskva: Zigfid Kronbax, M.Berlic i $\mathrm{K}^{\circ}$, Škola Berlica, Vil'gel'm Tryde, Promyšlennoe i kommerčeskoe obščestvo M.O.Vol'f, 1902.

Berlitz, M. D. Russkij učebnik. Sed'moe izdanie. S.Peterburg, Moskva: M.O.Vol'f, 1909.

Baranovskij, St. Russkaja xrestomatija. Kniga dlja perevodov s russkago jazyka. Gel'singfors:

Tipografija Frenkelja, 1848.

Šafranov, S. \& I. Nikolič. Russkaja xrestomatija dlja upotreblenija $v$ uciliščax pribaltijskix gubernij. Cast' pervaja. Izdanie tret'e knigi peresmotrennoj i uveličennoj. Proza. Revel': Izdanie Franca Kluga, 1972.

Golotuzov, F. Russkaja xrestomatija: kniga dlja perevodov s russkago jazyka na nemeckij. Izdanie cetyrnadcatoe. Leipzig: A. Neiman (Fr. Lukas), 1880.

Golotuzov, F. Russkaja xrestomatija. Kniga dlja perevodov's russkago jazyka na nemeckij. Izdanie 20, ispr. Mitava: Tip. I. F. Šteffengagena i syna. 1889.

Markov, Aleksej. Russkaja Xrestomatija. Otryvki iz sożinenij lučšix russkix pisatelej dlja čtenija i perevodov s russkago jazyka na nemeckij. I Cast'. Tekst s udarenijami, grammatičeskimi primečanijami i priloženiem polnago slovarja. Stuttgart: Carl Malcomes, 1894.

Vasilenko, E. \& E. Lamm. Sixty Lessons in Russian. Textbook. Moscow: Company A.V.P. - Zodiac. 1993.

Tokarev, K. A. Samoučitel 'rossijskago i pol'skago jazykov. Varšava: Tipografija na Rymarskoj ulice No. 744, 1838.

Paperna. A. I. Samouciitel' russkago jazyka. Kniga grammatičesko-praktičeskaja, primenennaja $k$ 
SRJa 1870

*SRJaK 1861

Syrku 1897

Šavrov 1994

Tixomirov 1893

TNM 1994

Tolstoj 1958

Tolstoj 1964

TW 1680s obščestvennomu i kommerčeskomu bytu Evreev. S pribavleniem pisem na ranye slučai, kommerčeskix pisem, obrazcov prosenij, zaemnyx pisem, zakladnyx, kupcix krepostej, kontrakıov, doverennostej, form vekselej, rospisok i proć. Varšava: Tipografija I. Gol'dmana, 1869.

Baljasnyj, N. Samoucitel' russkogo jazyka dlja umejuščix citat' po-pol 'ski. Rukovodstvo k izučeniju jazyka bez posobija učitelja. $S$ priloženiem obrazcov literaturnogo $i$ delovogo sloga. Varšava: Pečatnja Gol'dmana, 1870.

Il'minskij, N. I. Samoučitel' russkago jazyka dlja kirgizov, Kazan', 1861.

Syrku, P. A. Dva pamjatnika živogo russkago jazyka XVI v. Izvestiija Otdelenija russkago jazyka i slovesnosti Imperatorskoj Akademii nauk, 2/4, 1897, 1058-1067.

Savrov, V. B. Istorija konstrukcij samoletov v SSSR do 1938 g. Moskva: Mašinostroenie, 1994.

Tixomirov, Nikolaj. Pamjatniki otrečennoj russkoj literatury. Tom II. Moskva: V Universitetskoj tipografii, 1893.

Zabašta, N. A., R. N. Buneev \& E. A. Žarkova. Tri nedeli v Moskve. Moskva: Ballas, 1994.

Tolstoj, A. N. Sobranie sočinenij v desjati tomax. Tom tretij. Povesti i rasskazy 1917-1924. Aèlita. Roman. Moskva: Xudožestvennaja literatura, 1958.

Tolstoj, L. N. Sobranie sočinenij v dvadcati tomax. Tom 16. Publicisticeskie proizvedenija 1855-1909 gg. Moskva: Xudožestvennaja literatura, 1964.

Lunden, Siri Sverdrup. The Trondheim RussianGerman Manuscript Vocabulary. A Contribution to $17^{\text {th }}$-Century Russian Lexicography. Oslo, Bergen, Tromsö: Universitetsforlaget, 1972. 
UGR 1977

*UR 1795

*URJ 1929

URJa 1927

URJa 1938

URJa 1945

URJa 1969

URJa 1973
Ostapenko, V. I. Učus 'govorit's po-russki. Moskva: Russkij Jazyk, 1977.

[Tret'jakov, Vasilij]. Upotrebitel'nejšie razgovory na rossijskom i prostom. ili obščenarodno nyne grekami upotrebljaemom jazyke. $V$ pol'zu rossijskago junošestva i grekov, želajuščix obuçat 'sja rossijskomu jazyku. Izdannye Moskovskoj slaveno-greko-latinskoj akademii ucitelem ierodiakonom Vladimirom. Moskva: Universitetskaja tipografija u Ridigera i Klaudija, 1795.

Seifertová-Šrutová \& Nina, Ludmila Šrutová. Učebnice ruskèho jazyka. V Praze: Státní nakladatelství, 1929.

Gorovič, Dolgov, Žižilenko, Lavrov, Sizyx \& Trušin. Učebnik russkogo jazyka dlja nacional 'nyx otdelenij voenno-učebnyx zavedenij R.K.K.A. C. 1. Leningrad: Leningradskaja pexotnaja škola im. t. Skljanskogo, 1927.

Vasil'ev, G. P. Učebnik russkogo jazyka dlja luoravetlanskoj (čukotskoj) načal 'noj školy. Kniga vtoraja. Leningrad: Učpedgiz, 1938.

Loja, Ja. V., E. P. Ozolin, I. Petrov et al. Učebnik russkogo jazyka dlja latyšskix skol vzroslyx. C. I. Riga: Grāmatu Apgāds, 1945.

Baš, E.G., E. Ju. Vladimirskij, T. M. Dorofeeva, M. N. Lebedeva, V. I. Polovnikova \& L. N. Švedova. Učebnik russkogo jazyka dlja studentovinostrancev, obučajuščixsja na podgotovitel nyx fakul 'tetax vuzov SSSR. T.1-2. Izdanie vtoroe. Moskva: Vysšaja škola, 1969.

Baš, E.G., E. Ju. Vladimirskij, T. M. Dorofeeva, M. N. Lebedeva, V. I. Polovnikova \& L. N. Švedova. Učebnik russkogo jazyka dlja studentovinostrancev, obučajuščixsja na podgotovitel 'nyx fakul 'tetax vuzov SSSR. T.1-2. Izd. 3-e, pererab. Moskva: Vysక̌aja škola, 1973. 
V 21991

Vinogradov 1957

VRG 1707

Zoshchenko 1963

ŽMRR 1991

ŽS 1926

ŻS 1929
Levina, G. M. \& E. Ju. Nikolenko. Vladimir. Cast' 2. Moskva, Sankt-Peterburg: Zlatoust / Interdialekt, 1991.

Vinogradov, V. V. (ed.-in-chief). Bibliografičeskij ukazatel' literatury po russkomu jazykoznanijus 1825 po 1880 god. Vypusk 6. Učebniki $i$ metodičeskaja literatura. Moskva: Izdatel'stvo AN SSSR, 1957.

Panzer, Baldur. A. -E. Sellius, Vocabvlarivm RvssoGermanicvm (1707) und Rvssorvm Formvlae Loqvendi. Kritische Textausgabe der Handschrift Sign. Miscell D $4^{\circ} 55$ der Ratsbücherei Lüneburg mit kyrillischer Interpretation der russischen Wörter sowie Indices der deutschen und russischen Wörter mit Stellenverweis. Frankfurt, Bern, New York, Paris: Peter Lang, 1989.

Zoshchenko, Mikhail. Nervous People and Other Stories. Edited, with an Introduction by Hugh McLean. Translated from the Russian by Maria Gordon and Hugh McLean. Bloomington: Indiana University Press, 1963.

Akišina, A. A., X. Kano, T.E. Akišina. Žesty i mimika v russkoj reči. Lingvostranoved ceskij slovar'. Moskva: Russkij jazyk, 1991.

Purčeladze, Solomon Davidovið. Živaja strujka. Ucebnik russkogo jazyka. Tiflis: Gosudarstvennoe izdatel'stvo S. S. R. Gruzii, 1926.

Purčeladze, Solomon. Živaja strujka. Naðal'nyj učebnik russkogo jazyka. Tiflis: Gosizdat Gruzii, 1929. 


\section{References}

Armstrong 1978

Arutjunova 1999

Barth 1969

Basler 1987

Belin 2000

Belova 1999

Bcnz 1954

Bermel 2000
Armstrong, John A. Ideology, Politics, and Government in the Soviet Union. Fourth Edition. New York: Praeger Publishers, 1978.

Arutjunova, N. D. Jazyk i mir čeloveka. Moskva: Jazyki russkoj kul'tury, 1999.

Barth, Fredrik. Introduction in F. Barth (ed.), Ethnic Groups and Boundaries. The Social Organization of Culture Difference. Bergen-Oslo: Universitets Forlaget, London: George Allen \& Unwin, 1969.

Basler, Franz. Russischunterricht in drei Jahrhunderten. Ein Beitrag zur Geschichte des Russischunterrichts an deutschen Schulen. Wiesbaden: Otto Harrassowitz, 1987.

Belin, Nellie. Accommodating Native Speakers in the Intermediate Russian Class. Paper presented at AATSEEL 2000, clover.slavic.pitt.edu/djb/aatseel/2000.

Belova, O. V. Inorodec. In Tolstoj, N. I. (ed.), Slavjanskic drevnosti. Étnolingvističeskij slovar: T. 2. Moskva: Meždunarodnye otnošenija, 1999, 414418.

Benz. Ernst. Dic Beziehungen des AugustHermann-Francke-Kreises zu den Ostslawen. In Vasmer. Max (ed.), Festschrift fiir Dinytro Cjżevśkyj zum 60. Geburıstag am 23. März 1954. Berlin: Osteuropa Institut, 1954, 76-99.

Bermel, Neil. Language Standards and the Written Russian of Heritage-Speaker Students. Paper presented at AATSEEL 2000. clover.slavic.pilt.edu/ djb/aatseel/2000. 
Bemhagen 1968

Bernstein 1971

Bourdieu 1995

Boym 1994

Brostom 1979

Brown \& Levinson 1987

Byram 2000

Chevalier 2000
Bemhagen, W. Jacob Rodde as Verfasser des Gesprächsbuches "Domašnie razgovory" "Gespräche von Haussachen." In Grasshoff, H. \& U. Lehmann (eds.), Studien zur Geschichte der Russischen Literatur des 18. Jahrhunderts. Berlin: Akademie Verlag, 1968, 114-121.

Bernstein, Basil Class, Codes and Control. Vol. I. Theoretical Studies towards a Sociology of Language. London: Routledge and Kegan Paul, 1971.

Bourdieu, Pierre. Outline of a Theory of Practice. Cambridge: Cambridge University Press, 1995.

Boym, Svetlana. Common Places. Mythologies of Everyday Life in Russia. Cambridge, Massachusetts and London, England: Harvard University Press, 1994.

Archpriest Avvakum. The Life Written by Himself with the study of V. V. Vinogradov. Translations, annotations, commentary and a historical introduction by Kenneth N. Brostrom. Ann Arbor: Michigan Slavic Publications, 1979.

Brown, P. \& S. C. Levinson. Politeness: Some Universals in Language Usage. Cambridge: Cambridge University Press, 1987.

Byram, Michael (ed.), Routledge Encyclopedia of Language Teaching and Learning. London and New York: Routledge, 2000.

Chevalier, Joan. The Heritage Speaker: Developing Writing Skills. Paper presented at AATSEEL 2000. clover.slavic.pitt.edu/ djb/aatseel/2000.

Comrie, Stone \& Polinsky 1996

Comrie, Bernard, Gerald Stone \& Maria Polinsky. The Russian Language in the $20^{\text {th }}$ Century. Second Edition, Revised and Expanded. Oxford: Clarendon Press, 1996. 
Čyževškyj 1939

Čyževśkyj, D. Der Kreis A. H. Franckes in Halle und seine slavistischen Studien. Zeitschrift für slavische Philologie, 16, 1939, 16-68, 153-157.

Dabars with Vokhmina 1995 Dabars. Zita with Lilia Vokhmina. The Russian Way: Aspects of Behavior. Attitudes, and Customs of the Russians. Chicago: Passport Books, 1995.

Dinello 1998

Dinello, Natalia. Russian Religious Rejections of Money and Homo Economicus: The SelfIdentifications of the "Pioneers of a Money Economy" in Post-Soviet Russia. Sociology of Religion, 59/1, 1998, 45-64.

Elias 1969

Elias, Norber. Über den Prozess der Zivilisation. Zweite, um eine Einleitung vermehrte Auflage. Bd. 1-2. Bern und München: Francke Verlag, 1969.

Ėpštein 1990

Ėpštein, M. N. Priroda, mir, tajnik vselennoj... Sistema pejzainyx obrazov v russkoj poèzii. Moskva: Vysšaja škola, 1990.

Fedotov 1967

Fedotov, G. P. Lico Rossii. Paris: YMCA Press, 1967.

Foucault 1972a

Foucault, Michel. The Archeology of Knowledge. New York: Pantheon Books, 1972.

Foucault 1972b

Foucault, Michel. The Discourse on Language. In Foucault, Michel, The Archeology of Knowledge. New York: Pantheon Books, 1972, 215-237.

Gernentz, Korol \& Rösler 1988

Gementz, Hans Joachim, Tamara Korol \& Irmtraut Rösler. Das Gesprächbuch des Tönnies Fennes in seinem sprach- und geselschafthistorischen Umfeld. Gementz, Hans Joachim (ed.), Untersuchungen zum russisch-niederdeutschen Gesprächbuch des Tönnies Fennes, Pskov 1607. Ein Beitrag zur deutschen Sprachgeschichte. Berlin: AkademieVerlag, 1988, 13-86.

Giddens 1994

Giddens, Anthony. Central Problems in Social Theory. Berkeley and Los Angeles: UCP, 1994. 
Glowiniski 1996

Goffman 1959

Gracev 1995

Greenhill 1994

Holy 1996

Ionesco 1964

Johansen 1955

Judin 2003

Jakobson 1985

Kespert 1993
Glowiński, M. "Ne puskat' prošlogo na samotek." "Kratkij kurs VKP (b)" kak mificeskoe skazanie. Novoe literaturnoe obozrenie 22, 1996, 142-160.

Goffman, Erving. The Presentation of Self in Everyday Life. New York: Doubleday, 1959.

Gračev, S.V. Pedcigogičeskaja sistema N. I. Il'minskogo i ee razvitie $v$ teorii i praktike prosveščenija nerusskix narodov Povolž'ja (vtoraja polovina XIX-načalo XX veka. AKD. Nižnij Novgorod: Nižegorodskij pedagogičeskij universitet, 1995.

Greenhill, Pauline. Ethnicity in the Mainstream: Three Studies of English Canadian Culture in Ontario. Montreal \& Kingston - London - Buffalo: McGill - Queen's University Press, 1994.

Holy, Ladislav. The Little Czech and Great Czech Nation: National Identity and the Post-Communist Transformation of Society. Cambridge: Cambridge University Press, 1996.

lonesco, Eugene. Notes and Counter-Notes.

London: John Calder, 1964.

Johansen, Paul. "Fragment eines niederdeutschrussischen Sprachführers (1551)." Zeitschrift für slavische Philologie. 23/1, 1955, 275-283.

Judin, Aleksej. Rus. Gosudarstvo/ strana/ kraj i ukr. deriaval kraïnal kraj (opyt sopostavitel'nogo konceptual'nogo analiza). In print, Lublin, 2003.

Jakobson, Roman. "Metalanguage as a Linguistic Problem," in Roman Jakobson. Selected Writings. VII.Controbutions to Comparative Mythology. Studies in Linguistics and Philology, 1972-1982. Berlin, New York, Amsterdam: Mouton Publishers. 1985, 113-121.

Keipert, H. "Nochmals zur Kopenhagener Handschrift russischer Gespräche aus dem 17. Jahrhundert. "Zeitschrift für slavische Philologie 53/1, 1993, 285-303. 
Kljukov 1984

Lakoff 1973

Lebedev 1952

Levada 1995

Lewicki 1993

Magomedova 1997

Malia 1961
Kljukov, M. V. 'Ljudi', 'nastojaščie ljudi' (k probleme istoričeskoj tipologii ètnið̌eskix samonazvanij). In Džarylgasinova, R. S. \& V. A. Nikonov (eds.), Ėničeskaja onomastika. Moskva: Nauka, 1984, 6-12.

Lakoff, George. Hedges: A Study in Meaning Criteria and the Logic of Fuzzy Concepts. Journal of Philosophical Logic 2/1973, 458-508.

Lebedev, G. E. Russkaja knižnaja illjustracija XIX v. Moskva: Iskusstvo. 1952.

Levada, Ju. A. “Celovek sovetskij" pjat' let spustja: 1989-1994 (predvaritel'nye itogi sravnitel'nogo issledovanija. In Zaslavskaja, T. I. (ed.), Kuda idet Rossija?.. Al'ternativy obščestvennogo razvitija. II. Moskva: Aspekt Press, 1995, 218-229.

Lewicki, Roman. Semantyka pojęcia ojczyzny i jego funkcjonowanie we wspólczesnym języku rosyjskim. Bartminski, Jerzy (ed.). Pojęcie ojczyzny we wspolczesnych jezzykach europejskich. Lublin: Instytut Europy Środkowo-Wschodniej, 1993, 8391.

Magomedova, D. M. Polifonija. In Tamarčenko, N.D., S. N. Brojtman \& A. Sadeckij. (eds.). Baxtinskij tesaurus. Moskva: Rossijaskij gosudarstvennyj gumanitarnyj universitet. 1997 , 164-173.

Malia. Martin. Alexander Herie'n and the Birth of Russian Socialism 1812-185.5. Cambridge. Massachusetts: Harvard University Press. 1961.

McKay, Hill \& Buckler 1995

McKuy, John P., Bennett D. Hill \& John Buckler. A History of Western Society. Volume C. From the Revolutionary Era to the Present. Boston: Houghton Mifflin Company. 1995. 
Mey 1998

Mey, Jacob L. (ed.), Concise Encyclopedia of Pragmatics. Amsterdam: Elsevier, 1998.

Mil'kov \& Smol'nikova 1989 Mil'kov, V. V. \& L. N. Smol'nikova. "Beseda trex svjatitelej" v Drevnej Rusi i ee idejnomirovozzrenceskoe soderžanie. In Delokarov K. X. (ed.-in-chief), Obščestvennaja mysl'. Issledovanija $i$ publikacii. Vyp U!. Moskva: Nauka, 1989, 149-182.

Novičkova 1994

Novickova, T. A. Gibel' bogatyrej. Puti I miraži russkoj kul'tury. Sankt-Peterburg: Severozapad, 5886.

Orner 1973

Pekarskij 1862

Ortner, Sherry B. On Key Symbols. American Anthropologist 75, 1973, 1338-1346.

Pekarskij, P. Nauka i literatura v Rossii pri Petre Velikom. Issledovanie T. 1-2. Sankt-Peterburg: T-vo "Obshchestvennaia Pol'za", 1862.

Pesmen 2000

Potebnja 1968

Rejtblat 2001

Ries 1997

Riasanovsky 1961

Solov'ev 1927

Solovjev 1954

Pesmen, Dale. Russia and Soul: A Exploration. Ithaca and London: Cornell University Press, 2000.

Potebnja. A. A. lz zapisok po russkoj grammatike. T. III. Moskva: Prosvešenie, 1968.

Rejtblat, A. I. Kak Puskin vyšel v genii. Istorikosociologičeskie očerki o knižnoj kul 'ture Puškinskoj epoxi. Moskva: Novoe literatumoe obozrenie, 2001.

Ries, Nancy. Russian Talk. Culture and Conversation during Perestroika. Ithaca and London: Cornell University Press, 1997.

Riasanovsky, Nicholas V. Nicholas I and Official Nationality in Russia, 1825-1855. Berkeley and Los Angeles: University of California Press, 1961.

Solov'ev, A. V. Svjataja Rus'. Ozerk razvitija religiozno-obšcestvennoj idei. Sbormik russkogo arxeologičeskago obščestva v Korolevstve S. H. S., 1, 1927, 77-112.

Solovjev, A. Helles Rußland - Heiliges Rußland. In Vasmer, Max (ed.), Festschrift fuir Dmytro 
Sepeleva 1980

Tołstaja 1993

Tolstoj 1993

Trubacev 1985

Unbegaun 1969

Uspenskij 1992

Vasmer 1986-1987

Vorob'eva 1986
Cyževśkyj zum 60. Geburtstag am 23. März 1954. Berlin: Osteuropa Institut, 1954, 282-289.

Šepeleva, R. D. Pervoe pečatnoe praktičeskoe posobie po russkomu jazyku dlja inostrancev. Russkij jazyk za rubeżom, 1980, 6, 122.

Tołstaja, Swetłana. Ojczyzna w ludowej tradycji słowiańskiej. In Bartmiński, Jerzy (ed.), Pojęcie ojczyzny we wspólczesnych jezykach europejskich. Lublin: Instytut Europy Srodkowo-Wschodniej, 1993, 17-22.

Tolstoj, Nikita, I. Ėtničeskoe samopoznanie i samosoznanie Nestora Letopisca, avtora "Povesti vremennyx let". In Bartmiński, Jerzy (ed.), Pojęcie ojczyzny we wspólczesnych jezykach europejskich. Lublin: Instytut Europy Środkowo-Wschodniej, 1993, 67-75.

Trubačev, O. N. Jazykoznanie i ètnogenez slavjan. Voprosy jazykoznanija, 1985, 4, 3-17.

Unbegaun, B. O. Drei russische Grammatiken des 18. Jahrhunderts. Nachdruck der Ausgaben von 1706. 1731 und 1750 mit einer Einleitung. München: Wilhelm Fink Verlag, 1969 [Slavische Propylien, Bd. 55].

Uspenskij, B. Raskol i kul'tumyj konflict XVII veka. In A. Mal'ts (ed.), Sbornik statej k semidesjatiletiju prof. Ju. M. Lotmana. Tartu: Tanuskij universitet, 1992, 90-129.

Fasmer, Maks [Vasmer, Max]. Étimologičeskıj slovar' russkogo jazyka. V cetyrex tomax. Percvod i dopolnenija $\mathrm{O}$. N. Trubačeva. Izd. vtoroe, stereotipnoe. Moskva: Progress, 1986-1987.

Vorob'eva, I. V. Sistema vizual 'nyx komponentov v ućebnike russkogo jazyka dlja inostrancev. AKD. Moskva: Institut russkogo jazyka imeni Puškina, 1986. 
Wetherell \& Potter 1988 Wetherell, Margaret \& Jonathan Potter. Discourse Analysis and the Identification of Interpretative Repertoires. In Charles Antaki (ed.), Analysing Everyday Explanation. London: Sage Publications, 1988, 168-183.

Wierzbicka 1992

Wierzbicka, Anna. Semantics, Culture and Cognition: Universal Human Concepts in CultureSpecific Configurations. New York and Oxford:

Oxford University Press, 1992.

Wierzbicka 1997

Wierzbicka, Anna. Understanding Cultures through Their Key Words: English, Russian, Polish.

German, and Japanese. New York, Oxford: Oxford University Press, 1997.

Zaliznjak \& Levontina 1996 Zaliznjak, Anna A. \& Irina B. Levontina. Otraženie nacional'nogo xaraktera $v$ leksike russkogo jazyka. Russian Linguistics, 20, 1996, 237-264. 


\section{Index}

Absolute terms, 133

Aeroplan, 67

Age, 23, 69, 161, 163

Anti-commercialism, 177

Anti-materialism, 177

Audience of textbooks, 23, 33-34, 162-163

as addressee, 23, 24, 104

Authors of textbooks, 73

anonymity, 58-59, 86

as addressers, 23-24

as bonafide guides, $28,30-32,37$

as cultural mediators, 28, 85

as gatekeepers, 28-32, 37

gender of, 57-58

sources of authority, 58-64

team authorship, 60

Autocracy, 75, 76, 78, 116, $118,126$. 165

Autocratic discourse, 75-79, 106. $109,115,116-117,126-127,134$, $147,165,174,176,178-179$. $180,182,185,189$

Autocratic Model of Russian secondlanguage textbooks, 78-79, 105

Axiological vocabulary, 32-33, 196

Barbari, 1

Bárbaroi, 1

Bazar, 141-142

Birch, 143-144, 145-146

Birthday, 181

Broad Model of Russian secondlanguage textbooks, 36, 37, 78$79,80,81,97,104,105,109$.
$132,142-143,159,171,176$, 195, 196, 198. See also

Reconciliatory Model; Pluralist Model

Bridging discourse, 80-81, 106, 109 , $117-118,121,125,128-129,134$. $135,147-148,165,171,176,194$ $178,179-180,185,186,187$. 188,189

Bridging Model of Russian secondlanguage textbooks, 81, 105

Brynza, 30

Byt, 179, 187

Byzantium, 138

Citizenship. 17, 26, 107, 146, 192. 195

Civilization, 82, 87-90, 110, 195

Civilized-World doxa, 83, 106, 109. $110,116,121,176,185,195$

Civilized-World Model of Russian second-language textbooks, 36 , $37,42,56,81-82,84,85-90,95$. $97,104,105$

Code, 23, 43, 65

Colloquial language, 186

Commentary, 65-70, 71, 79, 104 $105,196,197$ avoidance of, 69

Common-Ground Model of Russian second-language textbooks, 32 , 35-36, 97. See also Broad Common-Ground Model of Russian second-language textbooks; Narrow Common- 
Ground Model of Russian second-language textbooks

Communicative situation, 23, 198

Communist discourse, 79-80, 81 , $106,109,110-115,121,124$, $127-128,134-135,144-146,147-$ $148,163-164,165,171,175$, $176,177,178,179,183-184$, $185-186,187,189$

Communist Model of Russian second-language textbooks, 80 , 105,170

Concept, 42, 107-108, 198. See also Valuable sum totals of concepts

Contextualization, 47, 51-53

Cooped-Up Insider Model of Russian second-language textbooks, 37, 81, 97, 105, 189194,196

Cross-Cultural Comparative Model of Russian second-language textbooks, 37, 81, 95-97, 97, 105, $133,196,198$

Cross-cultural comparison, 28

cuže-, 16

Dene, 3

Derżava, 133

Deutsch, 3

Dialogue, 97, 195

Directness, 196

Discourse, 65, 71-74 competition of discourses, 73-74

Discursive formation, 42, 50, 71 , 104-105, 197

Dissident discourse, 80, 106, 117 , $121,170,178,179,186,187,189$

Dissident Model of Russian secondlanguage textbooks, 80, 105

Doctrine, 71

Doxa. 80, 82, 83

Dux kollektivizma, 177

Duša, 172-176, 178, 189, 194

Elaborated code of communication, 83

Est: 67
Ethnicity, 16, 17, 26, 107, 146, 195

ethnicity-based model of humanity, 17, 25

Ethnocentric Outsider Model of Russian second-language textbooks, 37, 70, 81, 105, 194 . 196

Everyday talk, 49, 65-70, 196

Field of concomitance. See Statement

Field of memory, 45, 75-76

First-language acquisition, 47

First Nations, 16

Gender, 98-104, 107, 193-194. See also Linguistic gender dialogic treatment of, $98,102-$ 103

monologic treatment of, 98-102

Generic sentences, 92, 190

Global-Village discourse, 85, 106, 195

Global-Village Mosaic Model of Russian second-language textbooks, 36, 37, 85, 103-104, 105

Glossaries, 40, 51, 54, 56

Gorodovoj, 67

Gosudarstvo, 133

Grex, 172

Grice's quantity maxim, 142

Group, 177-194

Hanseatic League, 40

Heterodox discursive models, 74,75 $78,80-81,83,106,117$

History, 69, 76, 80, 93, 125, 149

Holidays, 126-130

Holy-Rus doxa, 82-85, 106, 109-110, $116,149,176,180,185,195$

Holy-Rus Model of Russian secondlanguage textbooks, 36, 37, 84, 104, 105

Homo Economicus, 178

Homo Orthodox, 178

Identity, 83, 98, 106, 107

European identity of Russians, 95 
excellence in second-language acquisition as an identity marker, 91

Self's own group, 146-176 spatial dimension of, 107, 133$146,180,182$ temporal dimension of, 107, 126$132,180-182,187$

Identity discourses, 70, 71, 74-81, $107,109,176,197$

pure vs. synthetic discourses, 109 pure, 109-115, 176 synthetic, 115-117, 176

Identity discursive formation, 64, 71 , $81-82,84,109,178,194,195$ $196,197,198$ paradigmatic sets of concepts. 108 syntagmatic chains of concepts, 108 valuable sum totals of concepts, 107-108 individuals vs. the group. 177 Illustrations, 53-55, 69, 81, 124, 143 , $161-165,173,176,186,189$ descriptive, 55, 70 exemplary, 70,71 generic, 71, 161, 163-164 ordinary, 71 prescriptive, 55, 56

Imeniny and related, 181

Imperative, 196

Impersonal constructions, 177

Individual, 177-194

ino-, 16

Inorodec, 5, 12-15, 26

Inostranec, 5, 9-11, 14-15

Insider perspective, 28, 37, 95

Interpretative repertoire, 72

Izvozčik, 67

Key symbol, 72

metaphorical summarizing symbols, 130, 143, 172, 176, 198 metonymical summarizing symbols, $126,130,138,165-172$, 176, 198

paradigms of symbols, 109

summarizing symbols, 108, 109 , 126, 132, 176, 196

syntagmatic chains of symbols, 123

Kinship, 133-134, 193

Kinship terms, 30-31

Klanjat'sja, 67

Kniga dlja čtenija, 41

Kosmopolit, 4

Kraj. 133

Krest 'janin. 82-83

Kušat', 67

Language, 107, 146, 195

Lenin V. I., 46, 111-112, 114, 115, $123,128,139,145,152,155$. $160,161,165,170-172,187$

Léskhē, 29

Linguistic discursive formation, 64 , 65

Linguistic gender, 98

Loyalty, 188

Macropragmatics, 197-198

Manners, 87-90

Mari, 3

Metalanguage. 23, 42, 65

Milicija and related, 67

Mir. 148-149

Modality, 32-33

Model of the world, 198

Modemity, 37, 56, 91, 195 transition from premodernity to. 85-97

transition to postmodernity from. 97-104

Monologue, 97, 195

Monuments, 108

Moscow, 86, 95, 117, 128, 129, 131 , $136,138-140,143-146,170$

Muscovy, 1, 138

Nacmen and related, 5, 15-16, 26 
Nameday, 180-182

Names of persons, 181

Narod, 142, 146-150, 176, 178

exemplary members of, 151 , 152-153, 154, 156-165, 176 generic members of, 151-152, $154,156-165,176,194$ ordinary members of, 151,153 154, 156-165, 176

Narrow Common-Ground Model of Russian second-language textbooks, 36, 37, 66-69, 75, 81, $105,154,159,194,196$

Nastojaščij, 7-8

Nationality, 56, 75, 116, 118, 193

Negative politeness, 94

Nenets, 3

Nerusskij, 5, 8, 26

Nominal style, 177

Non-agentivity, 177

Non-discursive mode, 85, 105, 106. 195

Novye russkie, 180

Object language, 23, 43, 65, 185

Orthodox Christianity, 69, 75, 78 . $83,90,94,95,109-110,116$. $118-123,126,128,172$

Orthodox discursive models. 74,75 , $79-80,83,106$

Orthographic reform. 67

Otčizna, 134

Otečestvo, 134

Other, 2, 16, 26, 82, 189

Outsider perspective, 28, 37, 95

Painjatnik, 108

Paradigmatic aspect of language. 4748

Parole vs. langue, 71

Patriotic discourse, 81, 106, 147

Patronymics, 69, 94, 95

Pero, 67

Peter I, 39, 69, 76-77, 96, 97, 108 , $115,116,152,154,166-167,185$ Pietism, 22
Pluralist Model of Russian secondlanguage textbooks, 104, 105

Policija, 67

Posobie, 41 učebnoe posobie, 41 praktičeskoe posobie, 41

Postmodernity, 37, 85, 195 transition from modemity to, 97 104

Praktičeskaja grammatika, 41

Praktičeskij kurs, 41

Predatel'stvo, 188

Pre-discursive universe, 81, 84

Premodernity, 37, 81-85, 195 transition to modernity from. 8597

Prescriptiveness, 32, 196

Privacy, 177

Private vs. Public, 177-194

Privetstuovat', 67

Profession, 23, 161, 192, 193

Proselytizing Model of Russian second-language textbooks, 32$35,37,78-79,81,97,104,105$, $109,132,142-143,159,170$, 176, 195

Prostota, 156

Proverbs, 33-34, 39, 45, 46, 51, 54, $62,64,68,69,76,86,122,132$

Puškin A. S., 4, 14, 61, 63, 64, 68, $95,102,108,125,129,139-140$, $143,147,153,160,165-166$. $167-169,171-172,191$

Razgovory, 41-42, 47

Reading selections, 34, 41, 42, 43 , 56,110

Reconciliatory discourse Soviet-time, 98, 109, 123-125 post-Soviet, 97-98, 109, 123. 125-126

Reconciliatory Model of Russian second-language textbooks Soviet, 80, 98, 105 post-Soviet, 81, 97-98, 105 
Reference grammars, 21-22, 47, 51, 56,61

Relational terms. 133

Religion, 94, 107, 109, 146, 195

Repetition, 43-46

Restricted code of communication. 83

Revolutionary discourse. 75,106 , 147

Riddles, 39, 86 .

Rodina, 134

Rome, 138

Rossijanin and related, 5-7

Ruckka, 67

Rukovodstvo, 41 praktičeskoe rukovodstvo, 41 učebnoe rukovodstvo, 41

Rus', 2, 148

Russkij, 2, 5, 6, 8, 82

Russkojazyčnyj, 26

Rynok, 141-142

-s (particle). 65-66

Samolet. 67

Samoucitel:, 41

Satana. 172

Suxarov A. D., 165, 169-170

Second-Language Learning discursive formation, 42, 48, 53 , $55,61,64,65,71,84,98,107$. $129,176,177,184,194,196,197$

Second-language textbooks. 21

a language as object of, 42, 60-61

a speaking subject as object of, 42. 56, 60-64, 97, 105, 151, 199 as messages, $23,26,50,65$ broad vs. narrow definition, 40 42, 55

Self, 2, 15, 26, 81, 82, 126, 133, 180 , 189,195

egalitarian model of, $1,4-5$

self-centred model of, 1-4, 82

Scrace. 172

Sexism, 101-102

Sibirjak. 141
Signs

visual, 54, 164, 194, 198

verbal, 54, 164, 194, 198

marked vs. unmarked, 198

generic vs. specific, 198

Simplicity. See Prostota

Sirene, 30

Slavophile discourse, 75-76, 82, 106 , $117,118,147-148,177$

Slip of tongue, $45-46$

SLL. See Second-Language Learning discursive formation

Sobomost', 177

Social class, 107, 146, 192, 195

Social distance, 94

Social role. 73

Sovetskij celovek, 7-8

Sovok, 7

Speakers of Russian as characters of Russian secondlanguage textbooks, 26-27 exemplary, 61, 62-64, 86, 151 generic, 62, 85-86, 151 ordinary, 62-63, 151

St. Petersburg. 10-11, 66, 129, 138. 140,142

St. Sergij Radonežskij, 165, 171-172

Stalin I. V., 34, 35, 114, 115, 123, $133,156,157,163,165,169$

Statement. 50, 56 coexistencc of statements, 47 concomitance of statements, 70 , $176,178,194,196,197$ manner of, $42.53,176$

Strainci, 133

Sijataja Rus:. 82

Symbol. See Key Symbol

Syntagmatic aspect of language, 47 48

Syntagmatic-paradigmatic balance. $50-53$

Sintrophos and related, 30

Sofer. 67

Šurin. 31 
Teaching method, 59-60

Teaching routine, $43,47-53$

Textbooks of Russian, 40 earliest, 38-40

for foreigners, 33-34, 162-163

for Germans, 24-25

for heritage speakers, 17

for inorodcy, 22-23, 162-163

for non-Russians, 18

for Russians, 18

prehistory of, 84

rate of publication, 38

one-book-for-all approach, 19-21

periodization, 42-43, 55-56

Truisms, 48-49

Ty pronoun vs. $V y$ pronoun, 94

Učebnaja grammatika, 41

Učebnik, 41, 55

Universe of discourse, 83, 104, 106. 198

Valuable sum totals of concepts. 107-108, 109, 126, 176, 196, 198 events, 107, 109, 110, 113-115, $116-117,126,148$ people, 107, 109, 110, 112-113, $116,118,124,126,146,148$. 177-194

time, 107, 109, 110, 113, 116 . $118,124,126,130,132,148-149$ territory, 107, 109, 110-112, 116, $118,126,133,135-138,141-142$. 144-146, 148-149

Valuable wholes. See Valuable sum totals of concepts

Value judgements. 32, 196

Visual individualization, 163-164

Vsečelovek and related, 3-4

Westernizer discourse. 75, 76-78. $106,117,118$

Winter, 130-132

Xrestomatija, 41 


\section{Illustrations}

\section{Russian Handwriting.}

Lotroce and small Letlers.

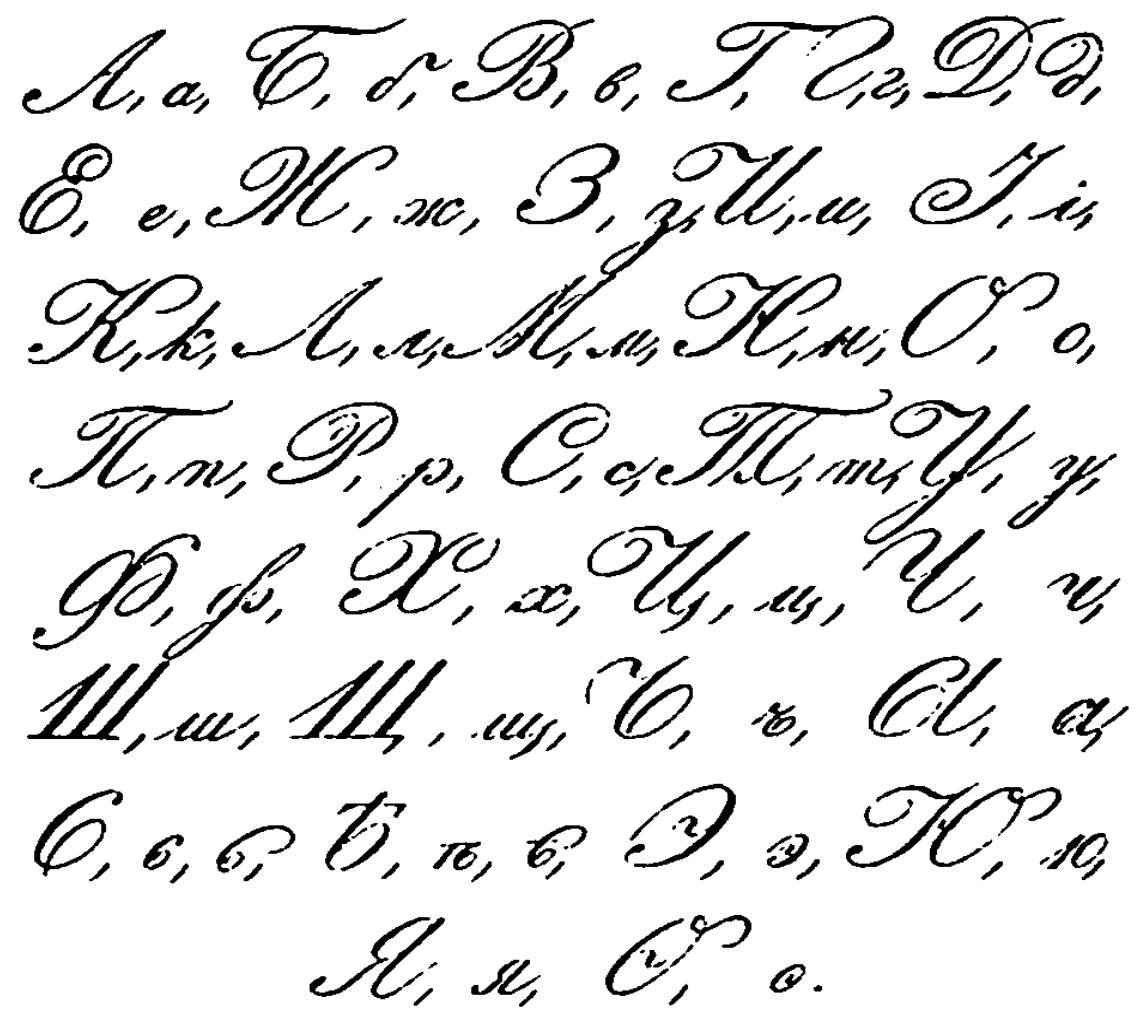

Illustration 1. The Russian alphabet during the Imperial period. Source: NPEM 1910, 7. Artist unknown. 


\section{HOW SOME RUSSIAN LETTERS ARE WRITTEN}

1. $1, \mu, s:$ céba, waq́ The letters $\mu, \mu, \Omega$ begin with a dot placed at one-fourth of the height of the letter.

2. 0 : Oscré, náce the ketter 0 is written without a joining stroke when it occurs at the beginning of a word.

3. $\kappa, \mu \therefore$ nuwó, Orató, $12 C$ The height of the letters $\mathscr{E}$. $\mathcal{L}$ is the same as that of the other letters.

4. The small letters $u, H, n, U, U, \mu, y$ have no "hook" in their upper part:

ubemór, úmyno, nawornó, nuauy

5. The letters $\mathcal{X}, x, \exists$ are joined to the preceding tetter: asc, Hosec, yse, ýso

6. Do not confuse the capital letters $\mathcal{Y}$ and $\mathcal{Z}$

7. Do not confuse the letters $y_{y}, y_{y}$ and $y$.

Illustration 2. Russian handwriting today. Source: RB 1999, 23. Artist unknown.
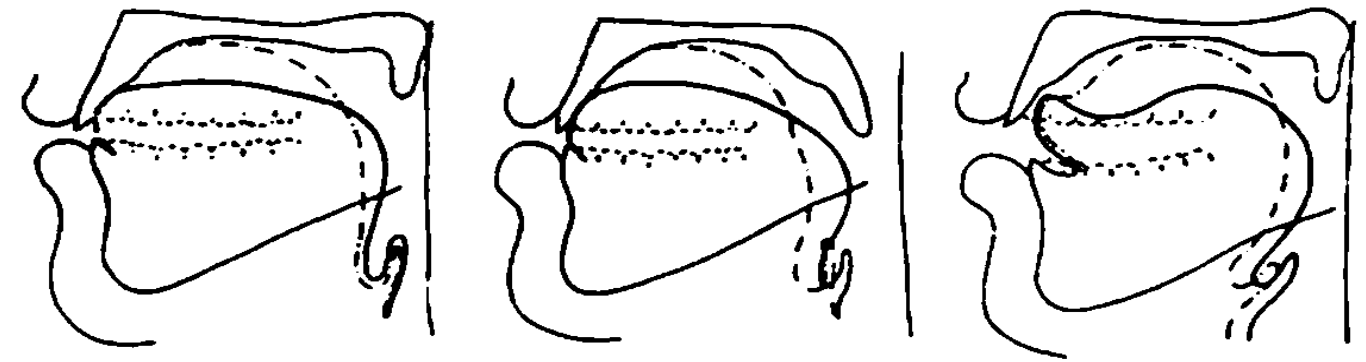

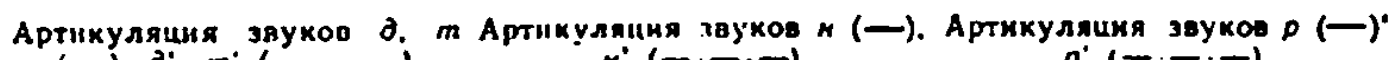

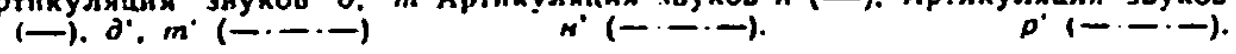

Illustration 3. Articulation of palatals in comparison with non-palatals. Source: $\mathrm{RJaSI}$ 1970, 18. Artist unknown. 


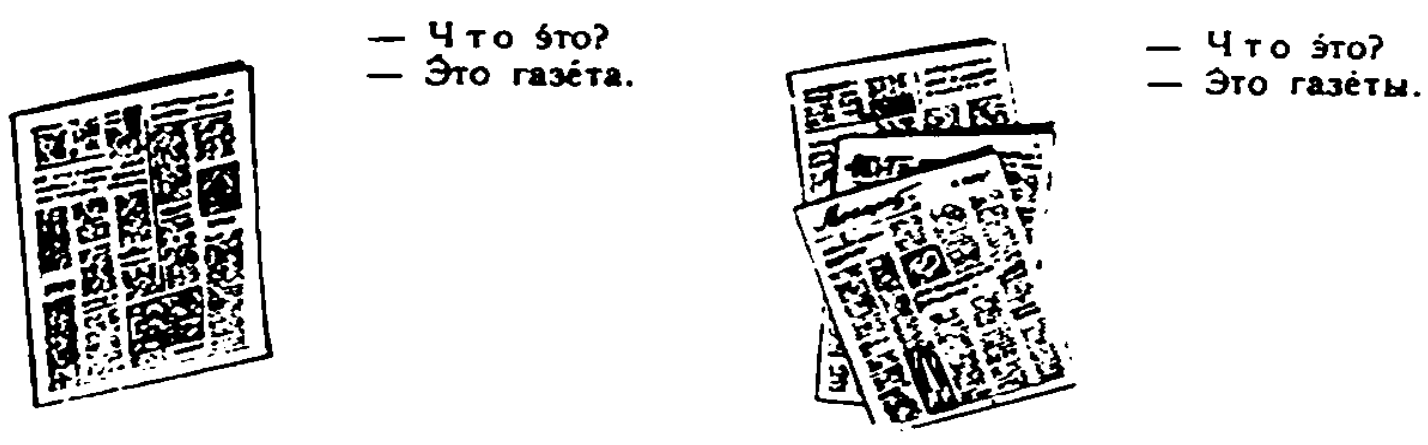

Illustration 4. Contrast of singular and plural. Source: SLR 1993, 16. Artists: E. Dorokhova and Y. Kharybin.



Illustration 5. Stationery. Source: DDÉ 1994, 4:3. Artist unknown.

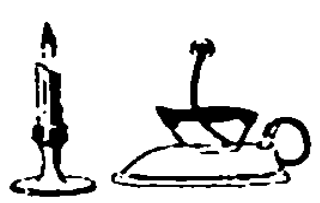

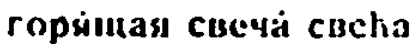
krojil ropu

I opsivurii yrkir npylsia IIC.T:1

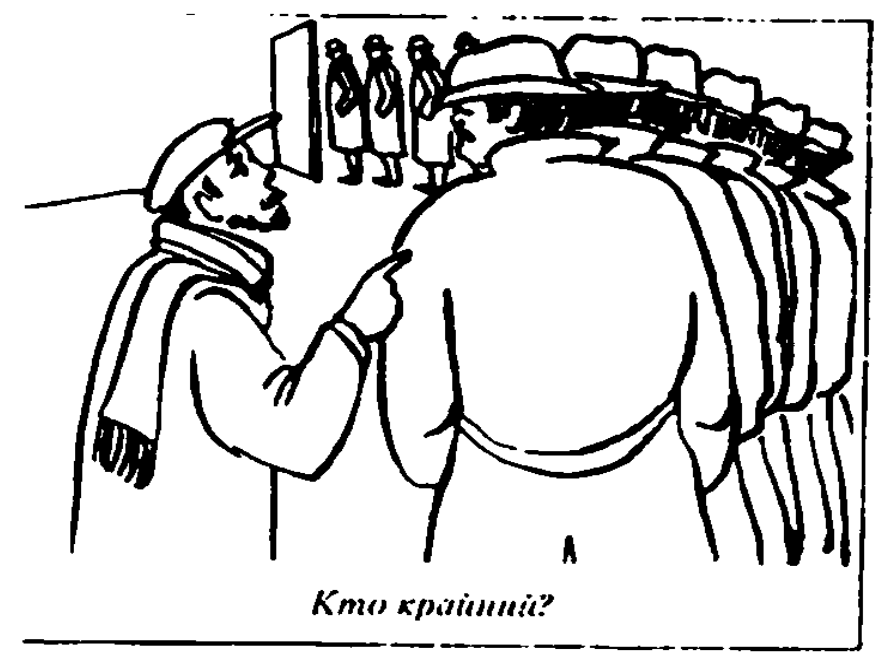

Illustration 7. 'Who is last in the line?' Source: RJaV 1995, 148. Artist: S. Vasil'cv.
Illustration 6. Contrast between gorjačč $i j$ 'burning' and gorjačij 'hot'. Source: RSČ 1940. 233. Artist unknown. 


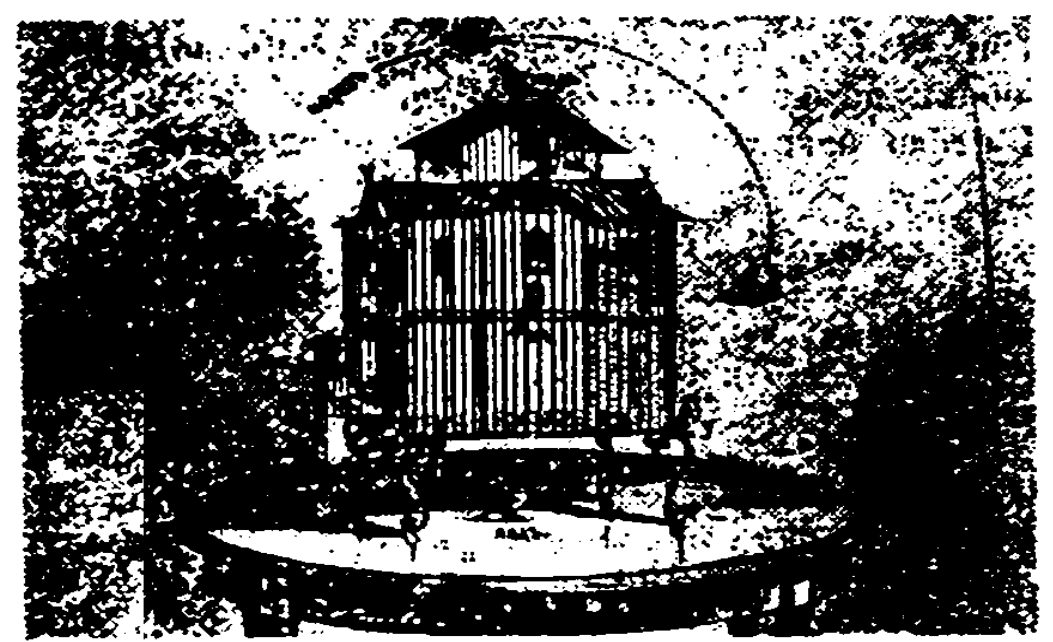

Illustration 8. Spatial meanings of the prepositions. Source: RS II 1908, 70. Artist: R. Siejn.

Krisa eesxim ma cmase.
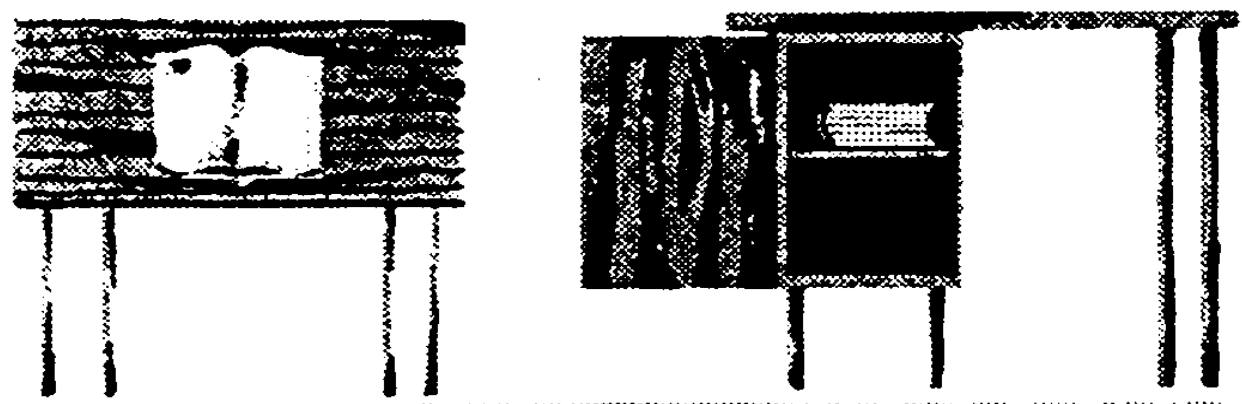

Illustration 9. Contrast of prepositions $v$ 'in' and na 'on'. Source: RJaSI 1970, 55. Artist: A. Alekseev.

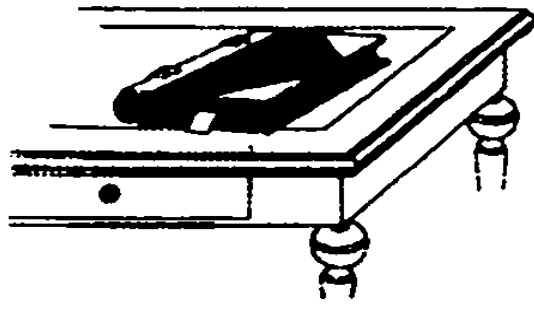

Книта на столе.

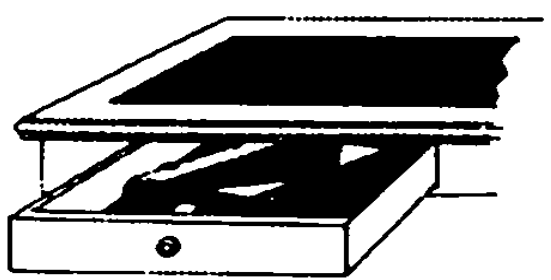

Книга в столе.

Illustration 10. Contrast of prepositions v 'in' and na 'on'. Source: RB 1999. 73. Artist: V. Karasyov. 


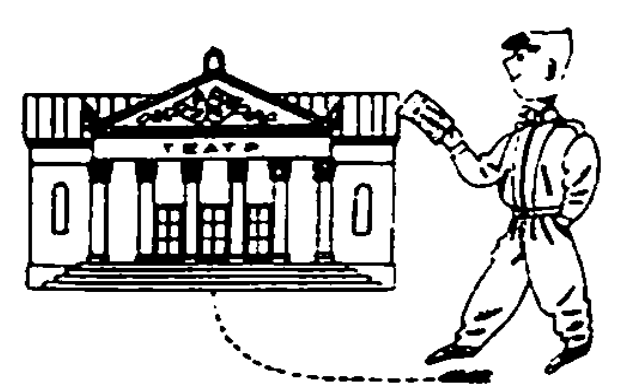

On йёт в теӓтр.

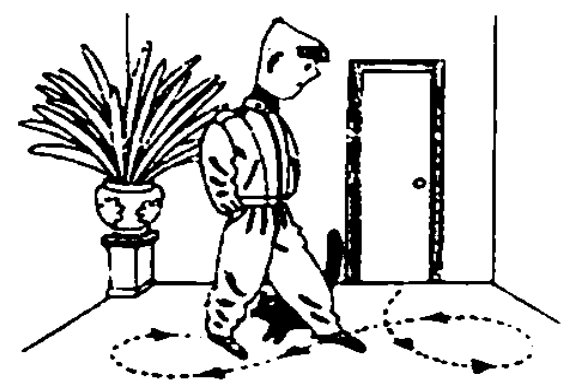

Он хо́дит по хоммнатс.

Illustration 11. Contrast of unidirectional idni 'to go' and multidirectional xodit' 'to go'. Source: RB 1999, 234. Artist: V. Karasyov.

Kyda?

KY



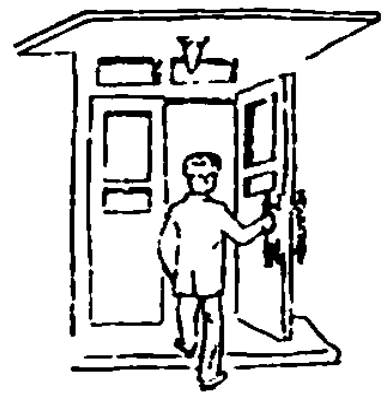

roe?

Tat ni oxizaer? Uil ónizaer jowa.

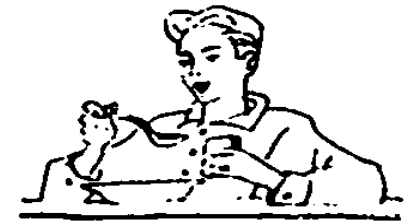

Illustration 12. Contrast of kuda 'whither' and gde 'where'. Source: URJa 1969 1: 48. Artist: I. S. Mal't.

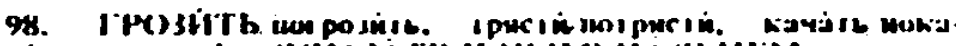


XI:CT

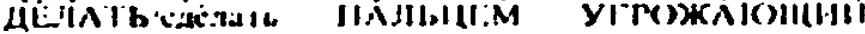

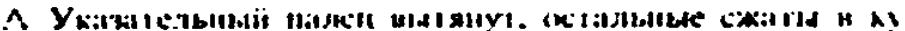

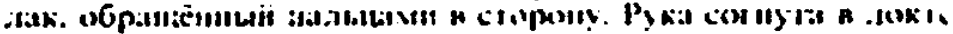

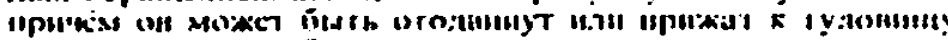

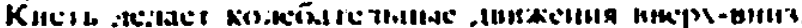

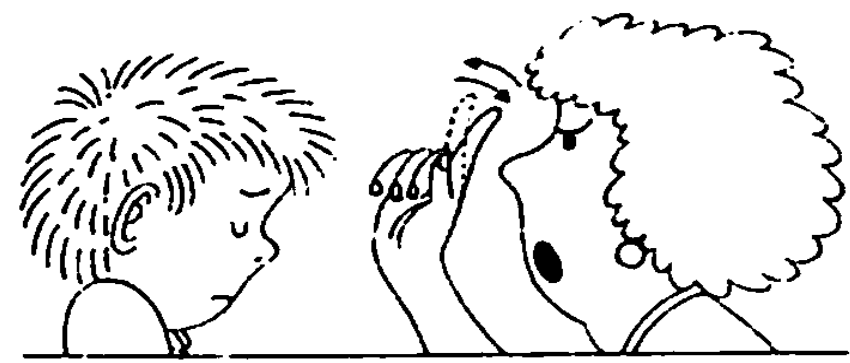

Illustration 13. 'To wag onc's finger at somebody.' Source: ŻMRR 1991, 58. Artist: V. Karasyov. 


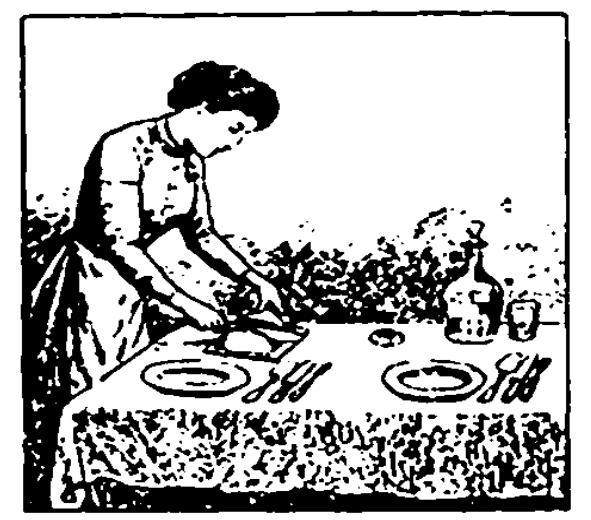

Приглу́га накрыва́еть столъ къ обБду.

Illustration 14. 'The maid-servant lays the table.' Source: FSR s.a. [1918?], 38. Artist unknown.
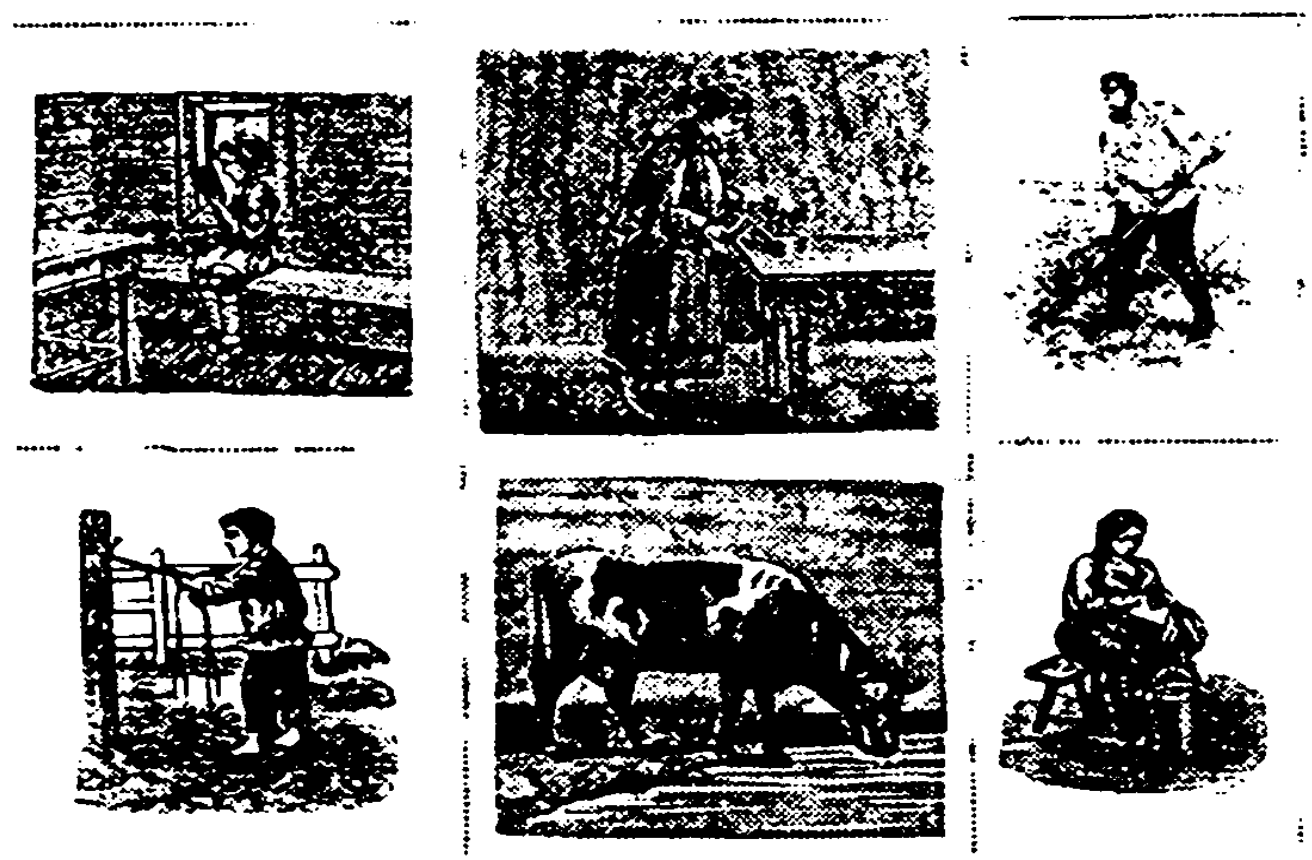

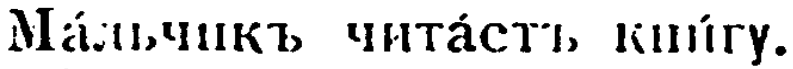

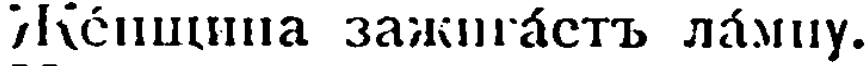
Ма́льчикъ въс்тт всрёвку.
Коса́pв ко́ситъ траву́. lípóma пьетт, вб.дy. jkénumua чи́ститъ p'liдыly.

Illustration 15. 'A boy reads a book. A woman lights a lamp. A boy braids a rope. A mower mows the grass. A cow drinks water. A woman peels a radish.' Source: PKORJa 1913, 64. Artist unknown. 

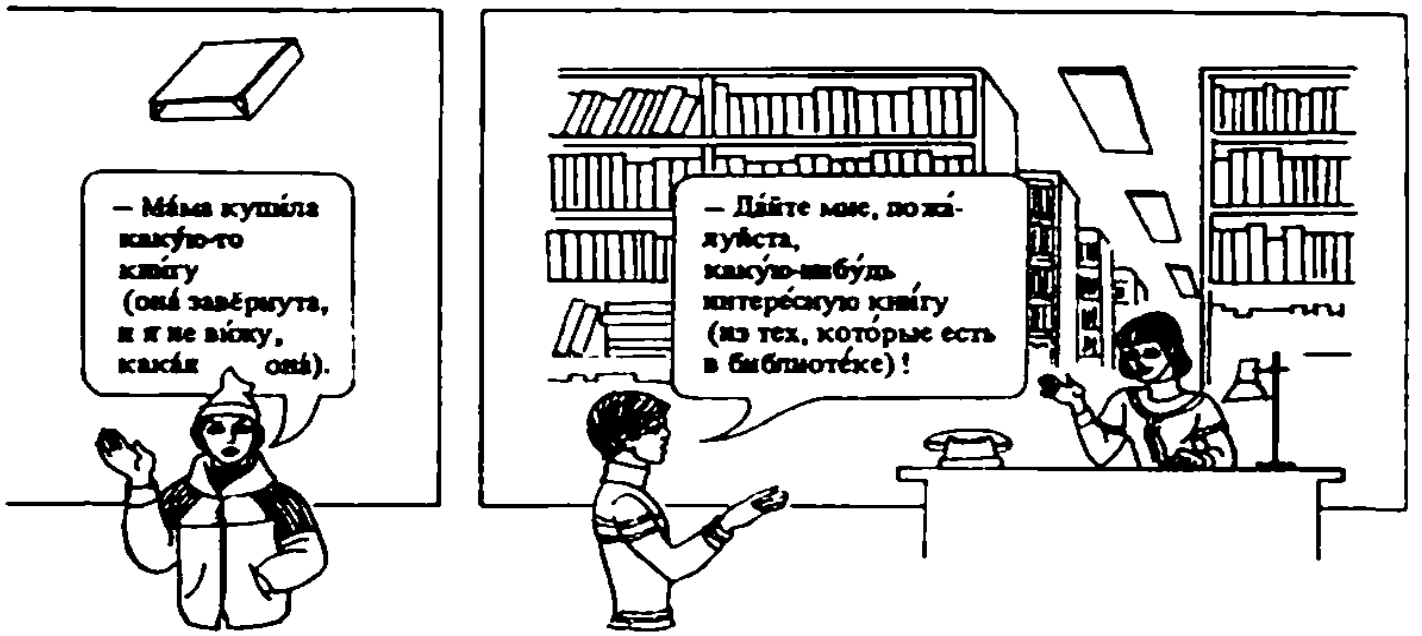

Illustration 16. 'Mum has bought a book (it is wrapped and I don't see what book it is).' 'Please give me an interesting book (out of those that the library owns).' Contrast between indefinite pronominal adjectives kakoj-lo and kakoj-nibud'. Source: GRJal 2000, 148. Artist unknown.

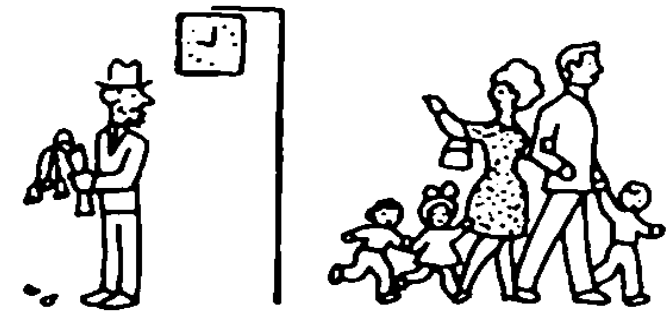

-. Ты все ещё ждёшь меня?
Illustration 17. 'A re you still waiting for me?' Source: RJaV 1976, 245. Artist: V. Alekseev.

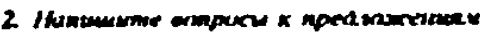

- Es rovit J laterte

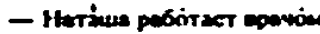

- Onci xopoubl rueopirr na-pjocror
}

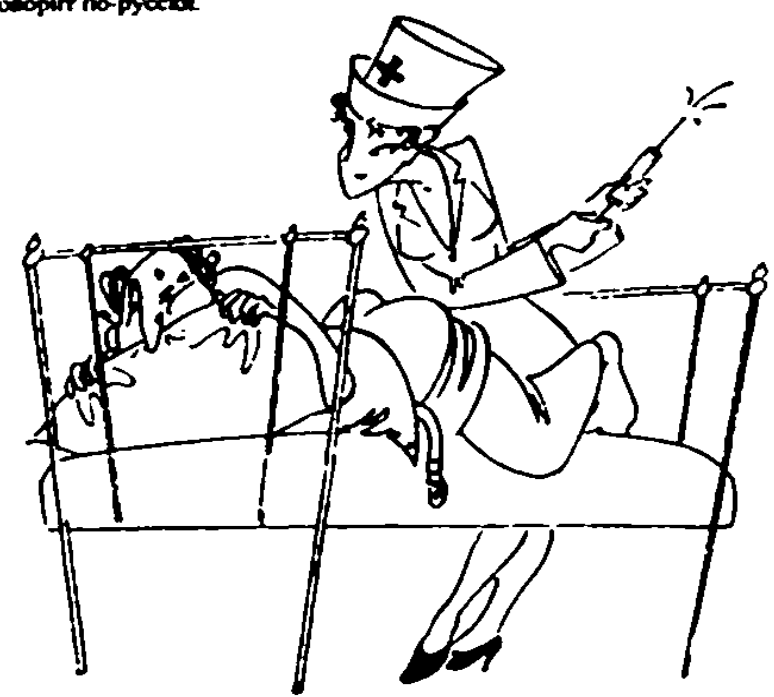

Illustration 18. 'Her name is Nataša. Nataša works as a physician. She speaks Russian well.' Source: PFK 1995, 9. Artists: I. N. Ćibiljaev and S. V. Semenov. 


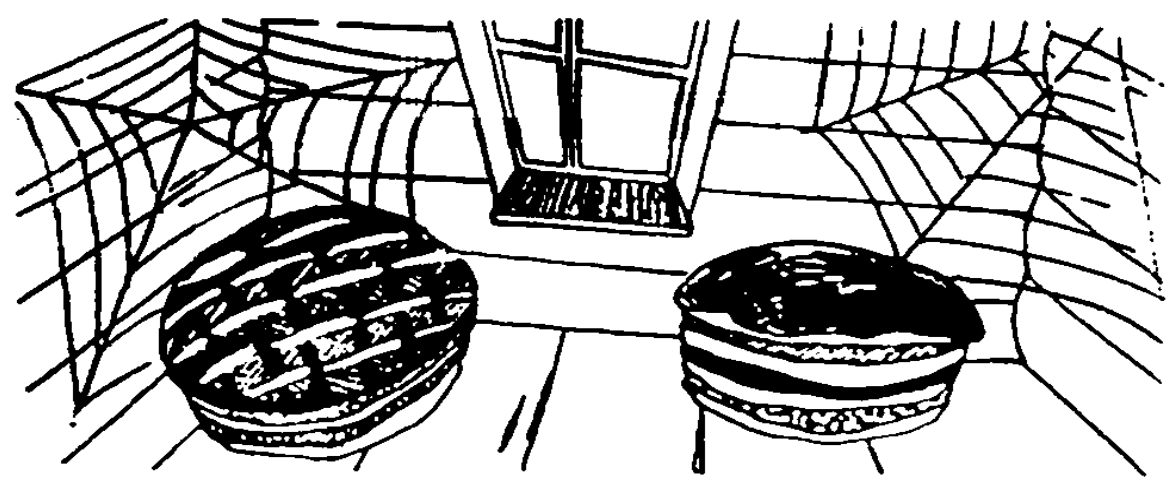

Не храсна изйа уелемие. а храсна пироха.ии

Illustration 19. Russian proverb 'What makes a hut attractive are not the corners but the pies.' RJaV 1995, 96. Artist: S. Vasil'ev.

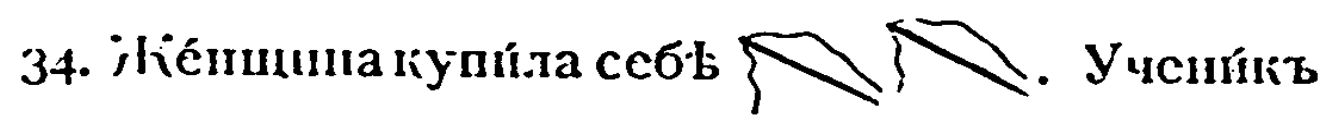

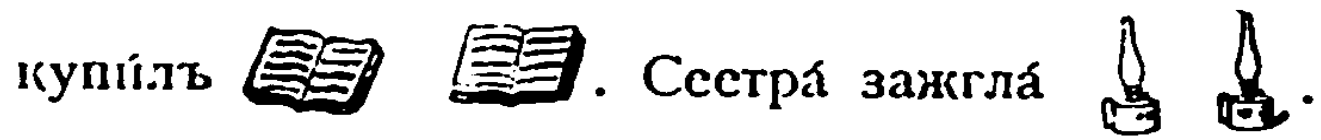
Крестьйинь сдњлаль
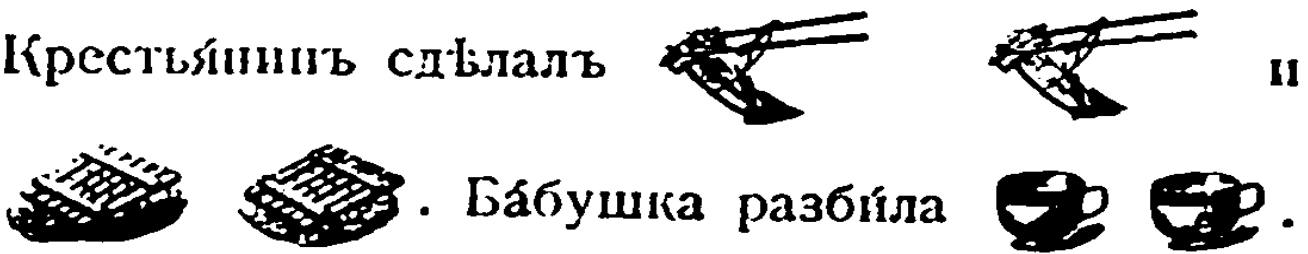

Ба́бушка разби́ла

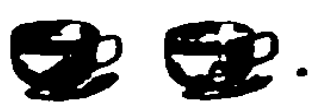


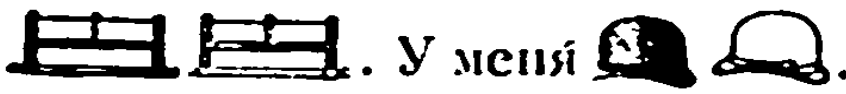

Illustration 20. Fill in the blanks with the noun corresponding to the picture. Pay attention to number. Source: PKORJ 1913, 50. Artist unknown.

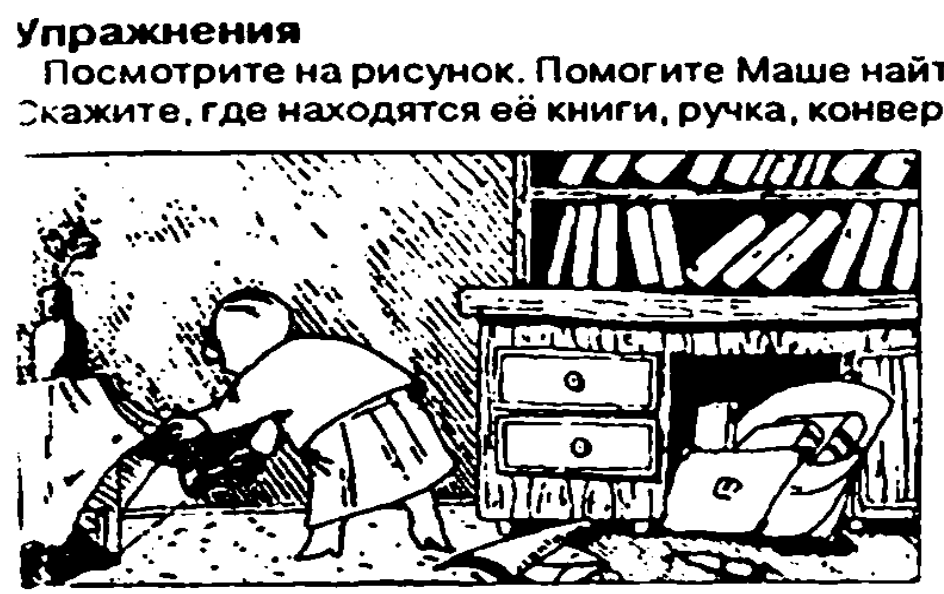

Illustration 21. 'Look at the picture. Help Maša find her things. Say wherc her books, pen, envelope and bricfcase are.' Source: TNM 1994, 33. Artist: Andrej Štapauk. 


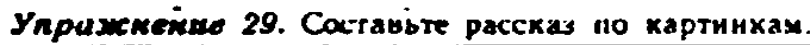

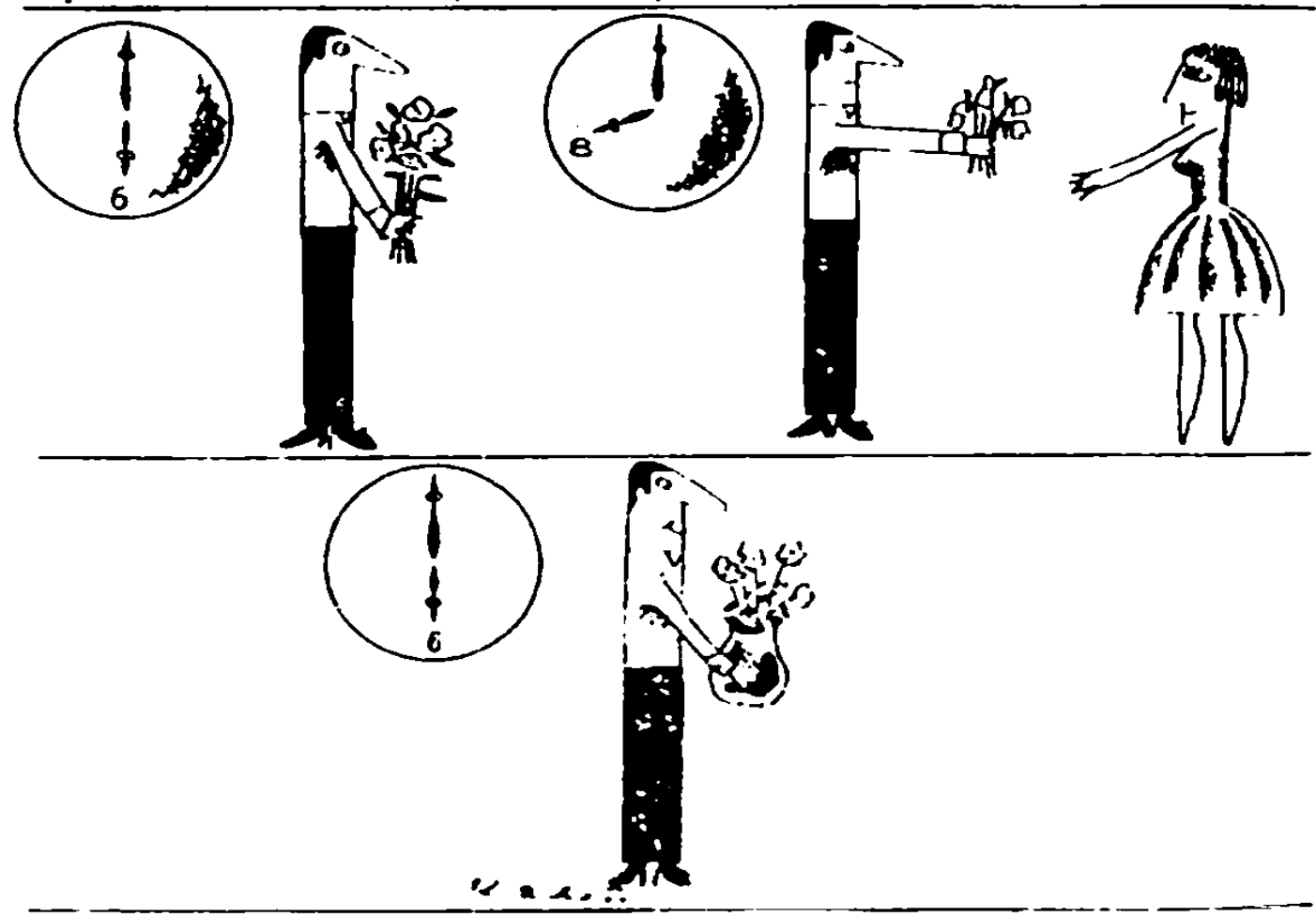

Illustration 22. 'Tell a story looking at the pictures.' Source: RJaSI 1970, 280. Artist: A. Alekseev.

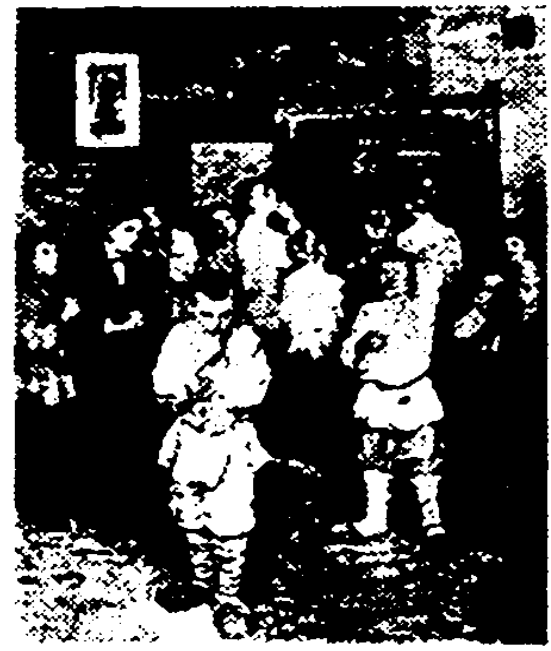

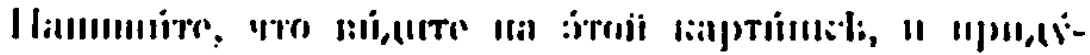

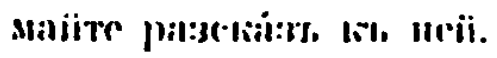

Illustration 23. 'Write what you see on this picture and think up a story to go with it." Source: FSR s.a. [1918?], 73. Artist unknown. 


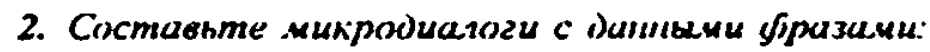

- Консчно, с удовольствисм.

- Бомось, что не смогу.

- Я тожс.

-

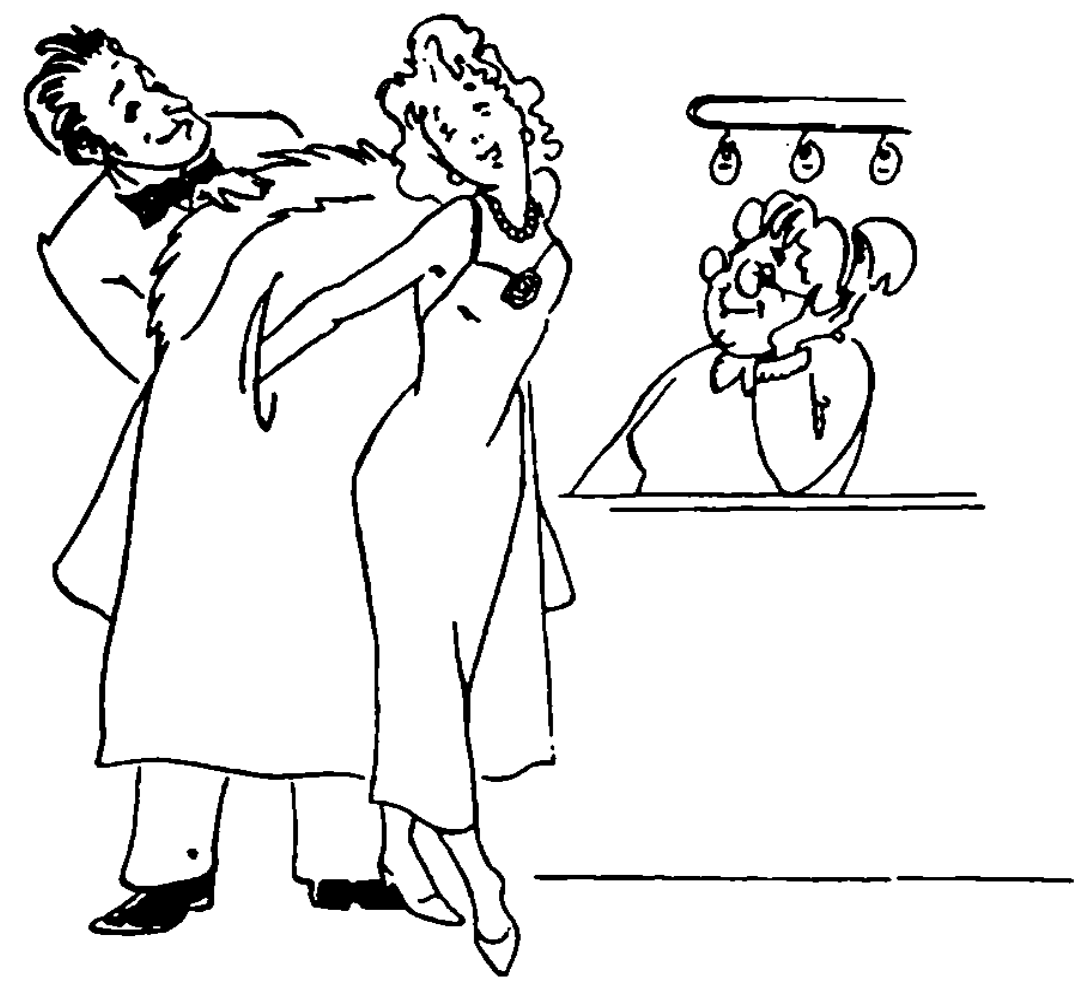

Illustration 24. "Make up a short dialogue using the following phrases: "Or course, with pleasure." "I am afraid I can't." "Me too." "Same here." Source: PFK 1995, 43. Artists: I. N. Cibiljaev and S. V. Semenov.

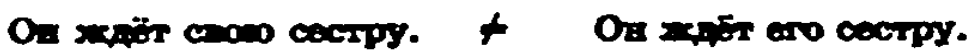
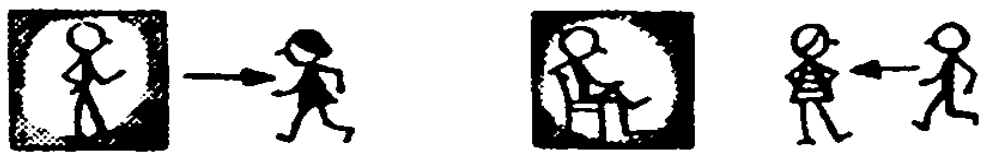

Oan zufer cooso cocespy.

Ora xuîr es ceorpy.


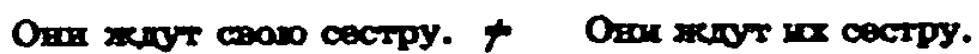
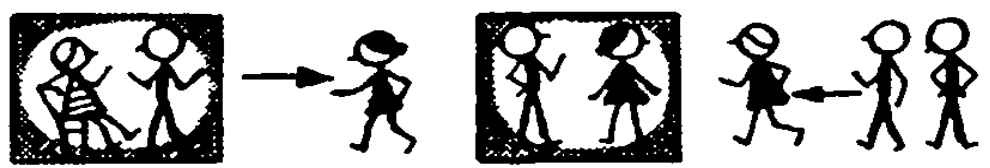

Illustration 25. Contrast of reflexive and third-person possessives. Source: DDP 1995, 2:11. Artist unknown. 

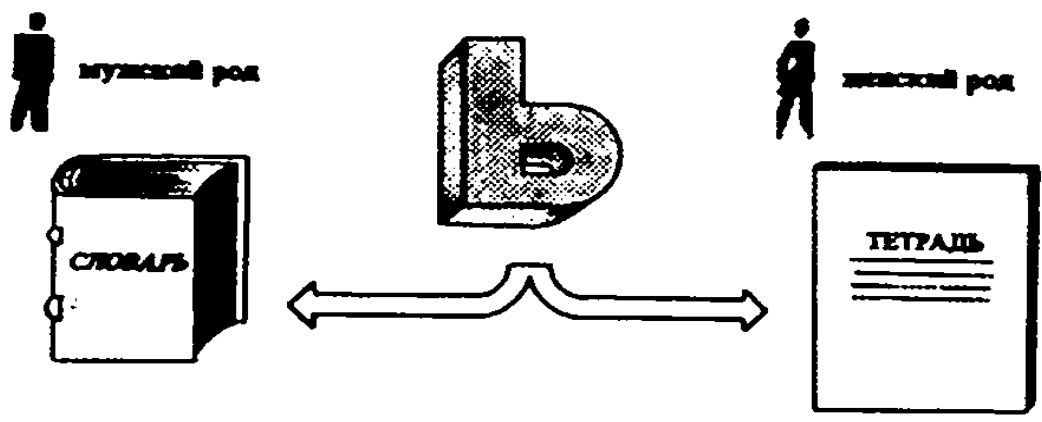

Illustration 26. Gender of the nouns ending in soft sign. Source: GRJal 2000, 16. Artist unknown.

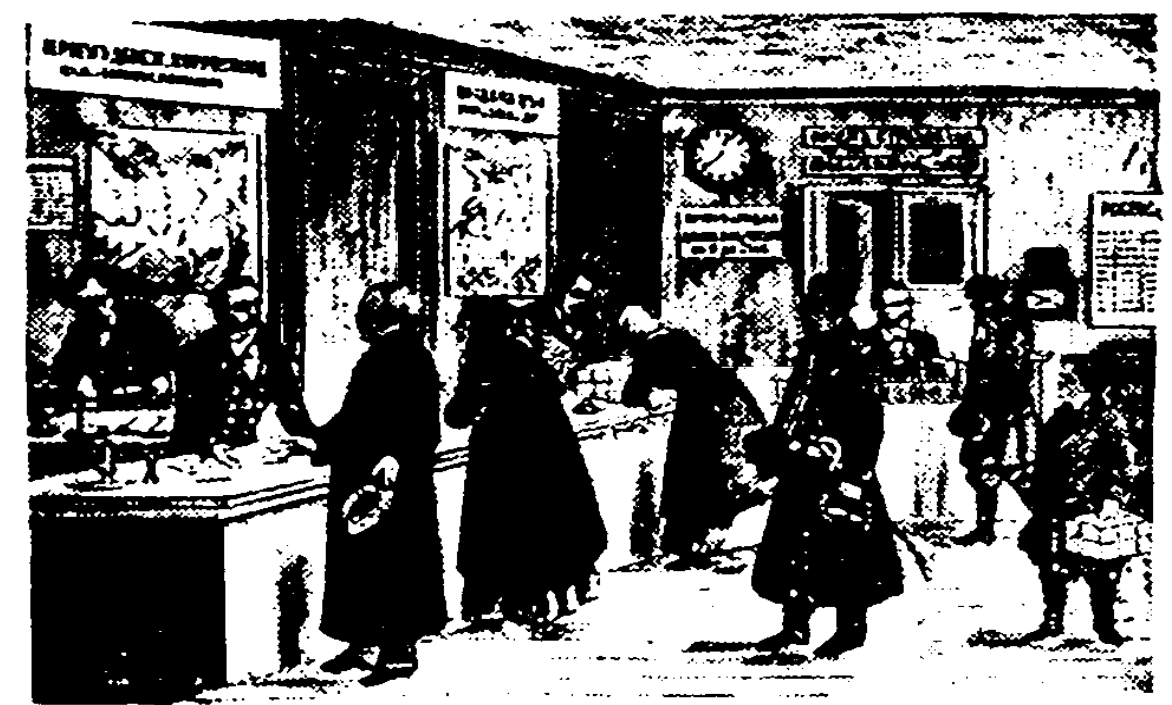

Illustration 27. V podtovoj kontore. 'At the post ofrice.' RR III 1914, 56. Artist unknown.

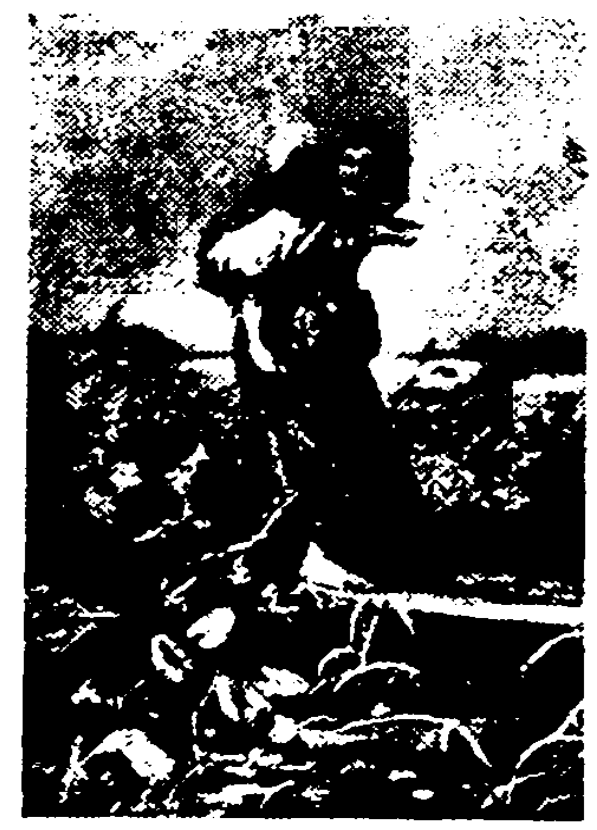

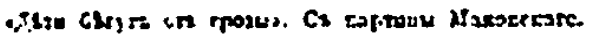

Illustration 28. Anter K. E. Makovskij's Children running away froin the storin (1872). RR III 1914, 94. 


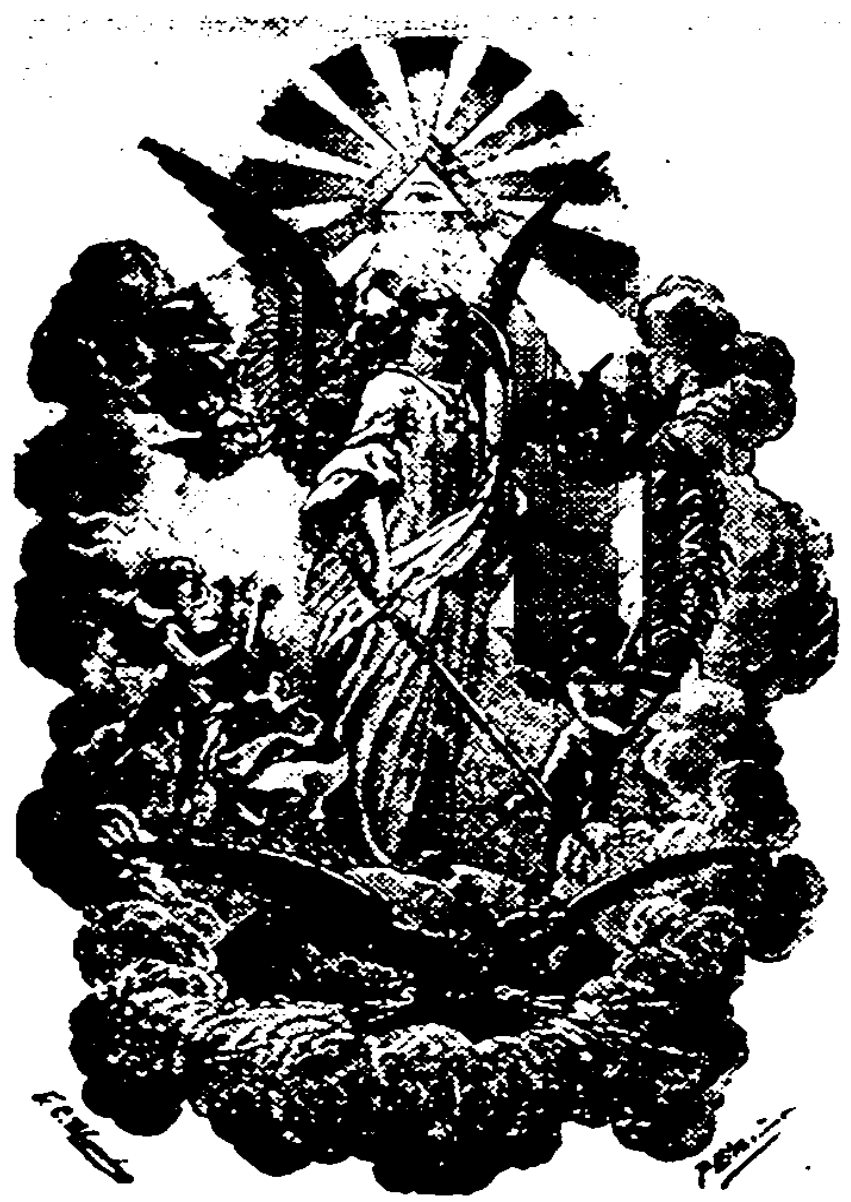

Illustration 29. Russkij narodnyj gimn. Bože Carja xrani./ Sil 'nyj, Dertavmyj, / Carstruj na slavu, (na slavu) nam. / Carsivuj na sirax vragam, / Car' pravoslavnyj! Boze Carja xrani! 'The Russian Folk Anthem. God Save the Tsar! You powerful and mighty Orthodox Tsar reign to our glory, keep in awe our enemies! God Save the Tsar!' Source: RS I 1908, 90. Artists: B. S. Ivanov and R. Stejn.

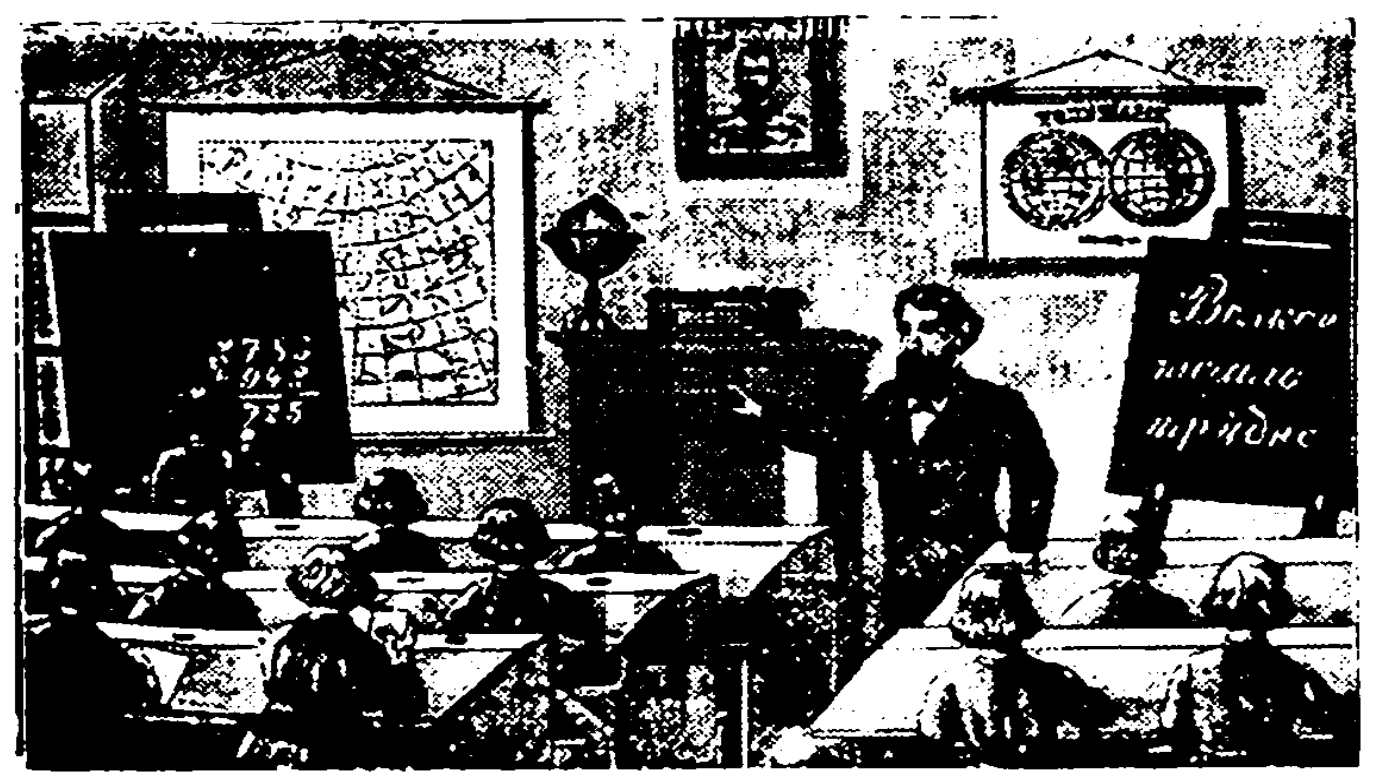

Illustration 30. School. Source: RS I 1908, 75. Artist unknown. 


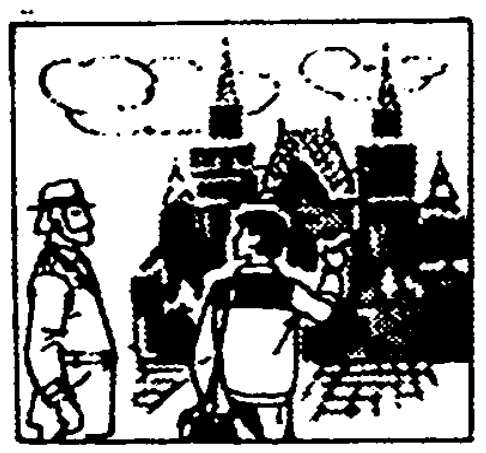

Illustration 31. Asking for directions in Mascow. Source: DDP 1995, 1:21. Artist unknown.

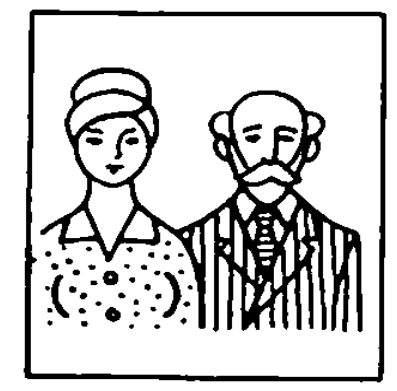

Это мояं ма̇мa. У неё есть оте́u. Он мой де́душка. Мой де́душка жи. вёт в дере́вне.

Illustration 32. 'This is my mom. She has a father. He is my grandfather. My grandfather lives in the countryside.' Source: RJaV 1976, 80. Artist: V. Alekseev.

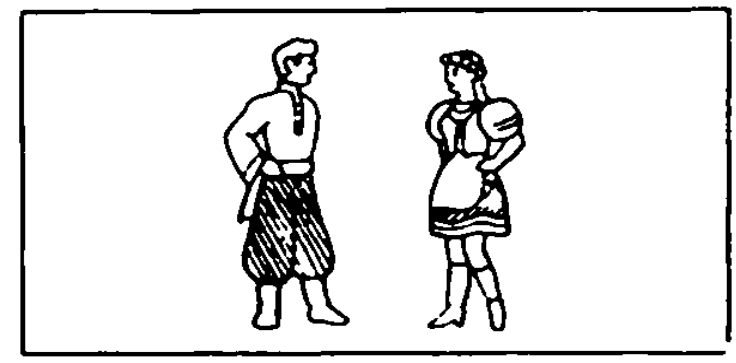

Это украйнец.

Это укран̆нка.

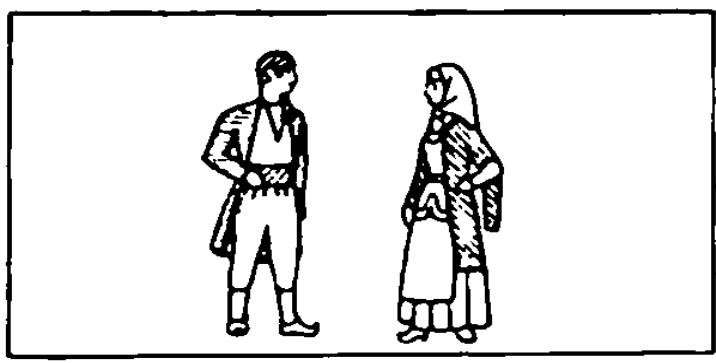

Это армяниян.

Это армяннка.

Illustration 33. 'This is a Ukrainian man. This is a Ukrainian womun. This is an Armenian man. This is an Armenian woman.' Source: RJaV 1976, 206. Artist: V. Alckseev. 


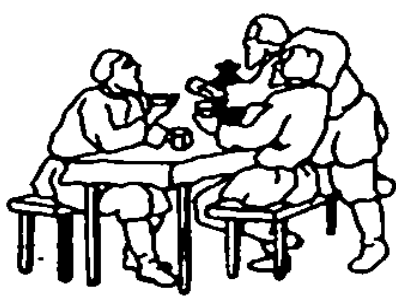

Пкть чай впрнку́ску йлн внакда́uky. Пи. ти чај грицкајуһн шећер или засла. ђен.

Illustration 34. 'To drink tea sucking small bits of sugar or sweetened'.

Source: RSČ 1940, 116. Artist unknown.
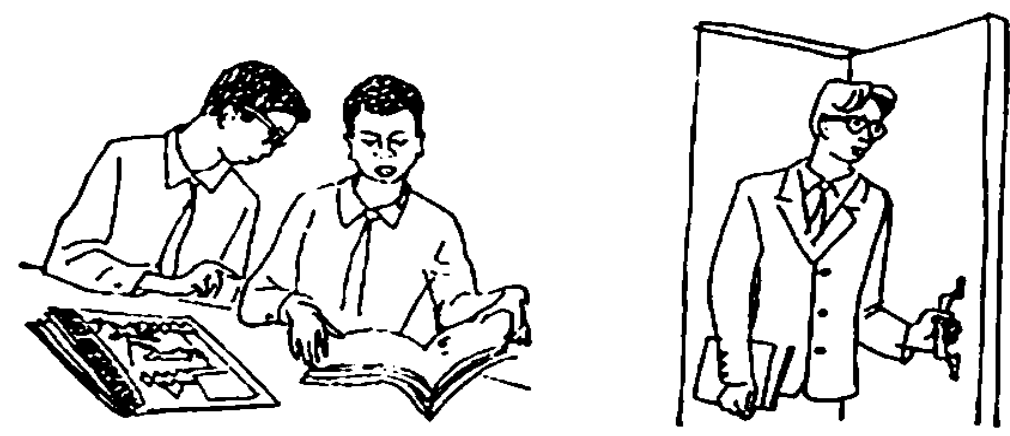

Illustration 35. Volodja and his friends Abu and Dialo from Guinea. Source: URJa 1969, 1:28. Artist: I. S. Mal't.

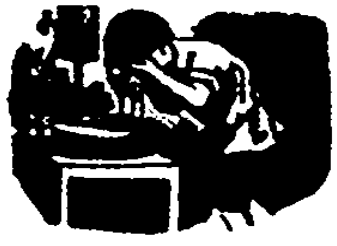

умы-ва́ç-cu

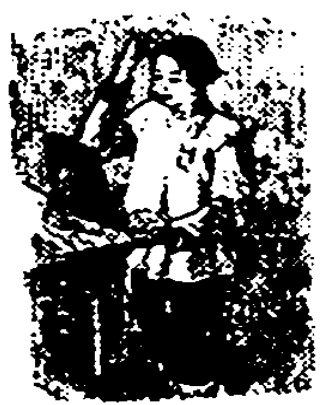

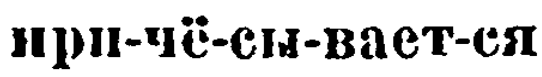

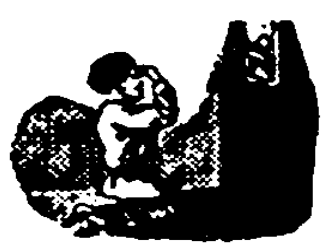

Jí-.IIIT'-8.)

Illustration 36. '[He] is washing up. [He] is combing. [He] is praying'. Source: PKORJa 1913, 19. Artist unknown. 


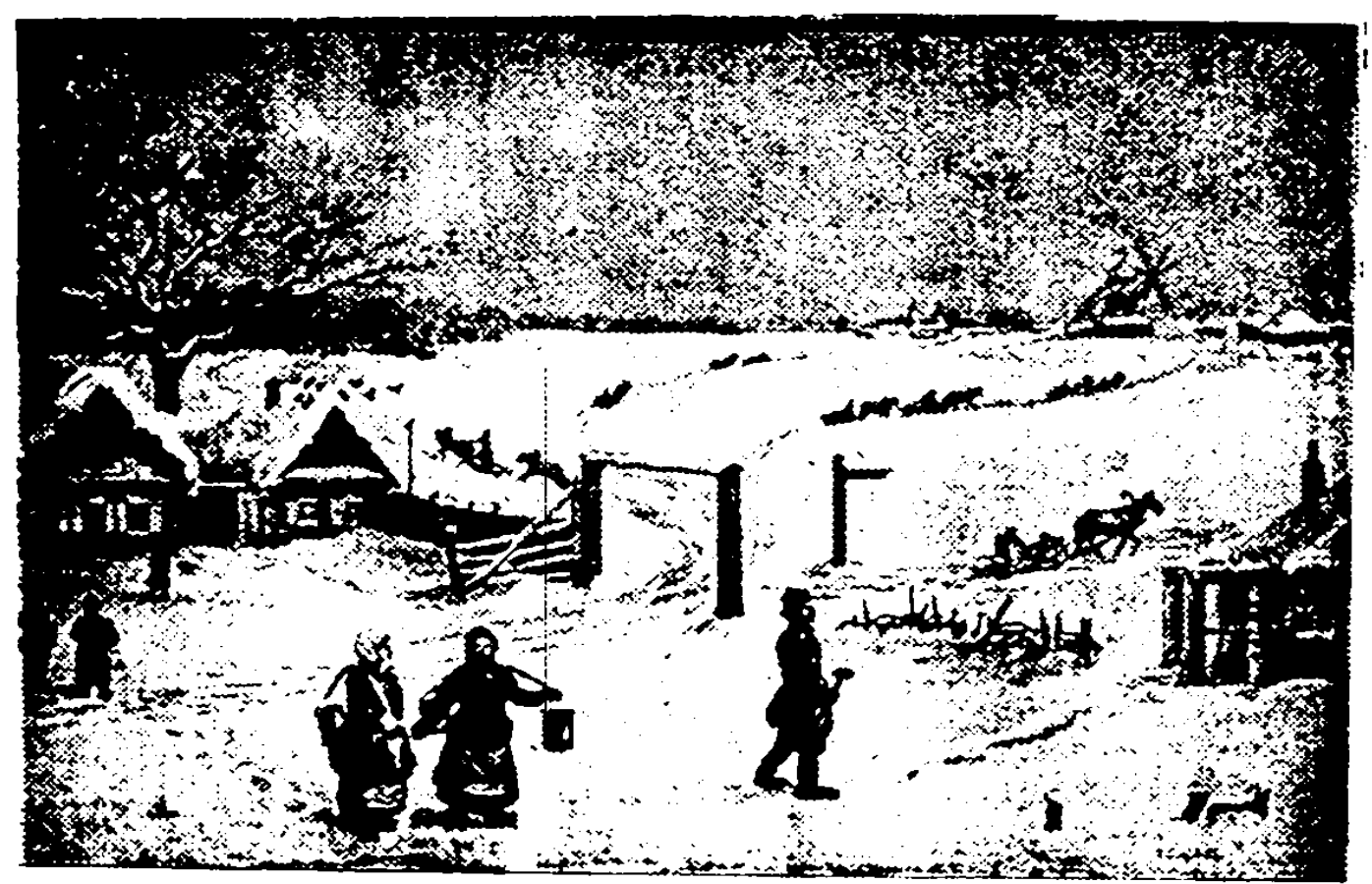

77. Hactálio у́тро. IІросиу́лись дю́ди и по-

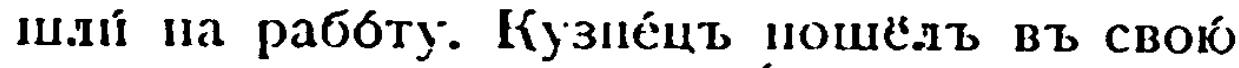

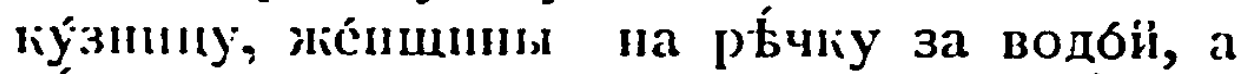

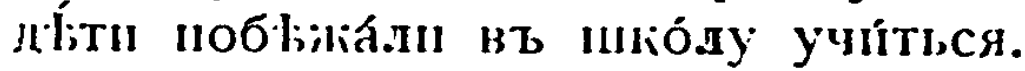

Ilactámo jópo. Просиўлись мужики́ ॥

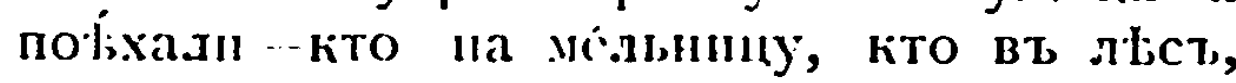

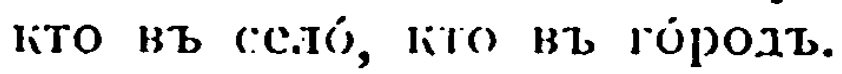

Illustration 37. 'Morning has come. People woke up and went to work. The blacksmith is going to his smithy, the women to the river for water and the children to school to study. Morning has come. The peasants woke up and left, everybody after his business: one has set off for the mill, another for the forest, one is going to the village, another to town." Source: PKORJa 1913, 68. Artist unknown.

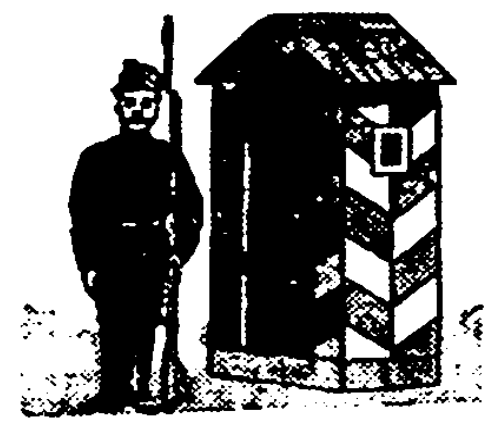

Illustration 38. Cusonioj 'Sentry'. Source: RS I 1908, 43. Artist unknown.



Illustration 39. 'Don't you know where pedestrians walk? They should use only the sidewalks.' Source: SI.R 1993, 209. Artists: E. Dorokhova and Y. Kharybin. 


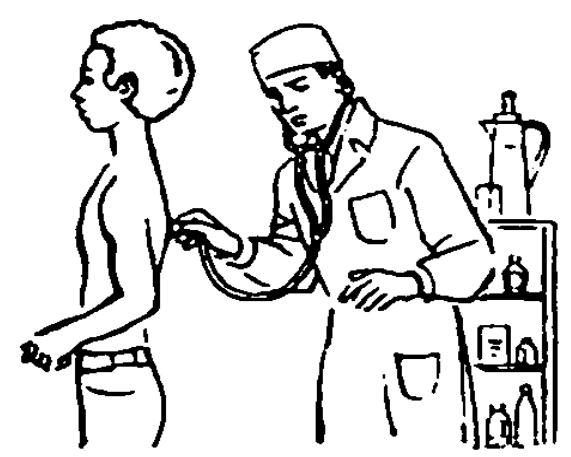

Illustration 40. Doctor's appointment. Source: UGR 1977, 92. Artist: V. G. Alekseev.

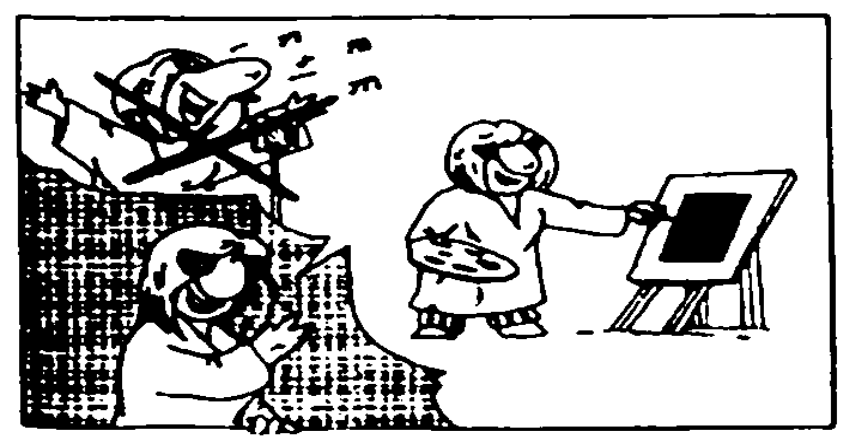

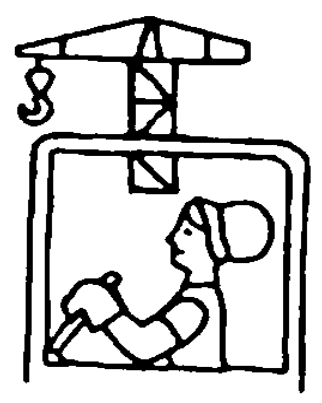

Illustration 41. 'She is a crane operator.' Source: RJaV 1976, 238. Artist: V. Alekseev.

Illustration 42. - Éto Sjuzanne?

- Da, éro Sjuzanna.

- Ona pevica?

- Net, ona ne pevica, ona

xudotnica.

'Is this Susan?' 'Yes, it is Susan.'

'Is she a singer?' 'No, she is not a singer. She is a painter.' Source: TNM 1994, 7. Artist: Andrej Stapouk.

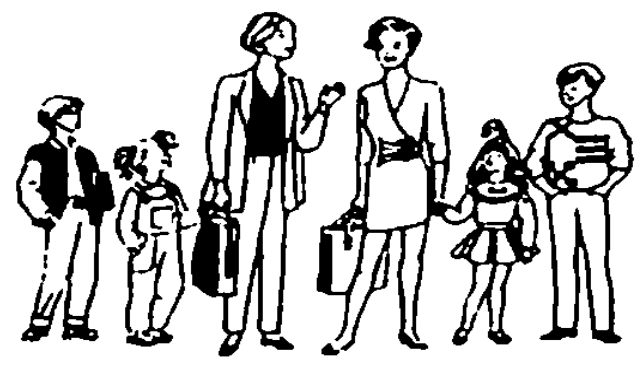

Màтери rоморйт, а сниовsі и домери c.iviuasor.

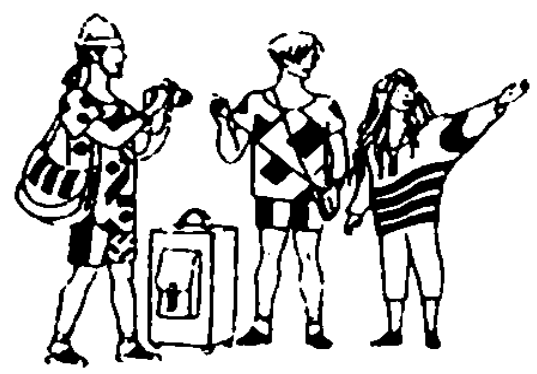

Эти тісзи - турйсзы-иностраниш.

Illustration 43. 'The nothers are talking and [their] sons and daughters are listening. These people are foreign tourists.' Source: SI.R 1993, 45. Artists: E. Dorokhova and Y. Kharybin. 


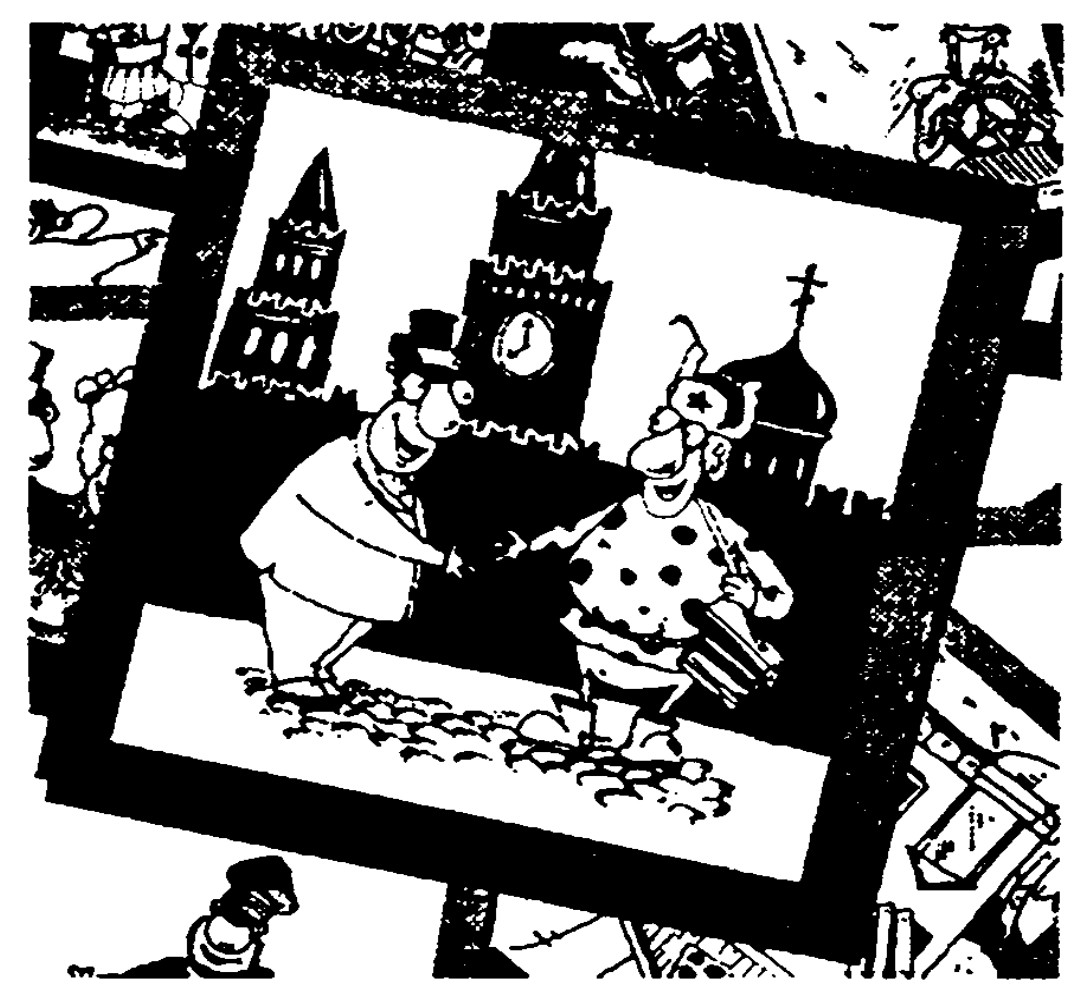

Illustration 44. Davajte poznakomimsja 'Let us get acquainted.' Source: TNM 1994, 5. Artist: Andrej Štapauk.



Illustration 45. Volodja and his foreign friends. Source: UR.Ja 1973 1:113. Artist: $\mathbb{k}$. F. Dolja.



$$
\text { cral-plét-xal }
$$

Illustration 46. 'Old woman'. Source: PKOR.Ja 1913, 18. Artist unknown.

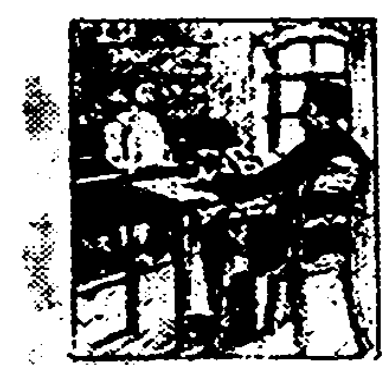

Illustration 47. The teacher is testing the schoolboy'. Source: PKORJa 1913, 61. Artist unknown. 


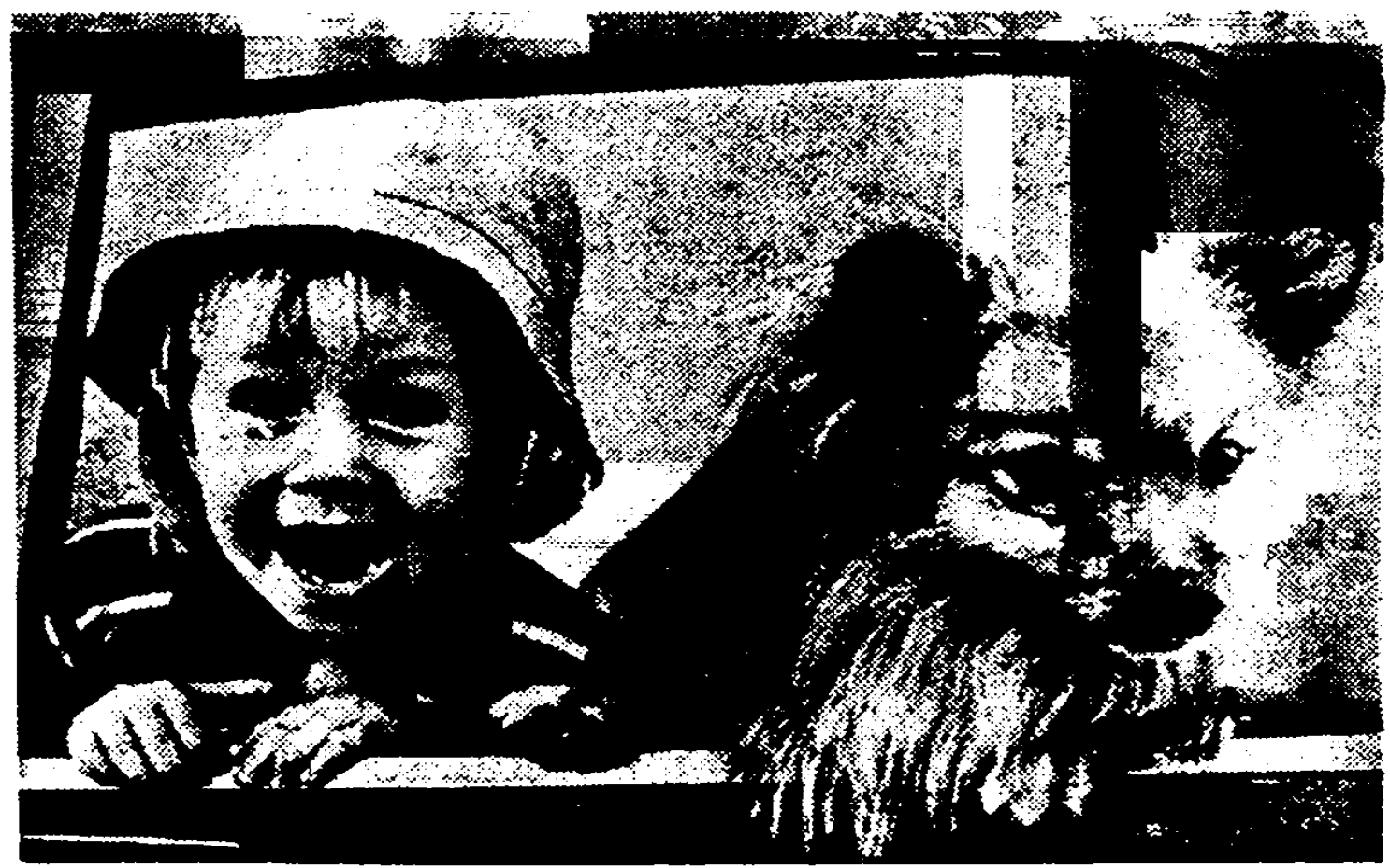

Illustration 48. 'Do you like pets? Do you have pets? If you do, tell us about them'. Source: RST 1985, 188. Photographer unknown.

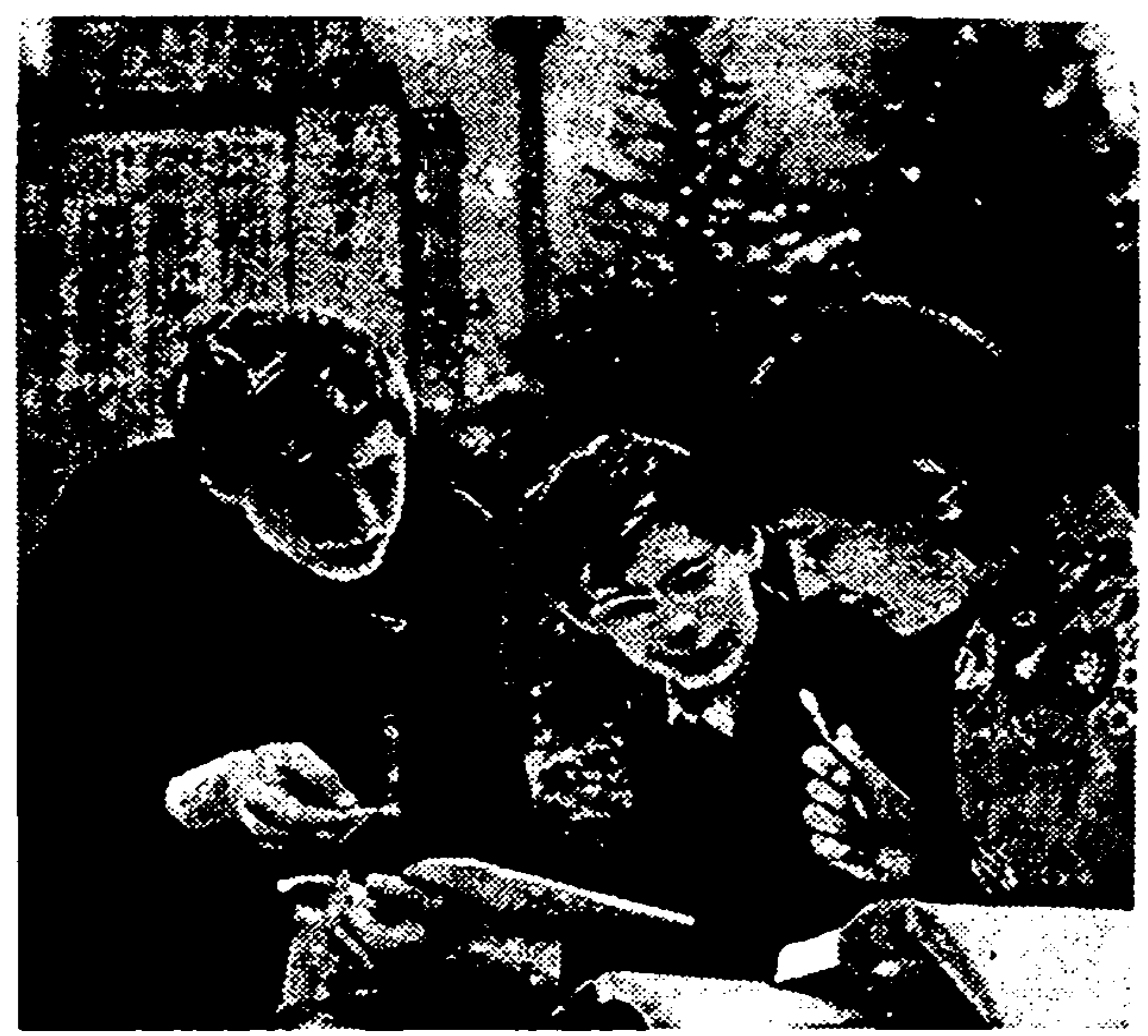

Illustration 49. Students at the Moscow State University. Source: RJaV 1976. 266. Photographer unknown. 


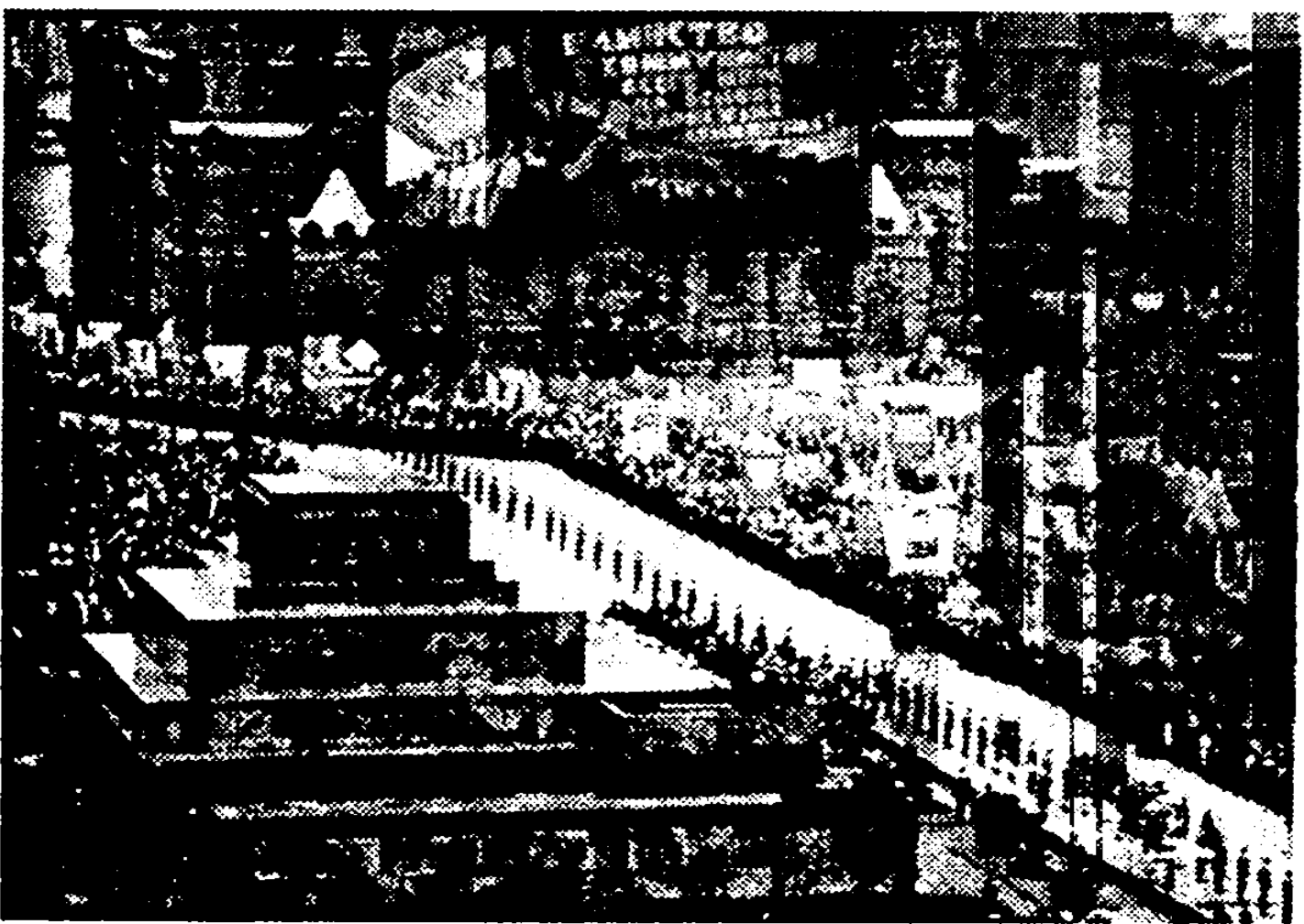

Illustration 50. Celebration of the anniversary of the Great October Revolution. Source: URJa 1973 1:239. Photographer unknown.

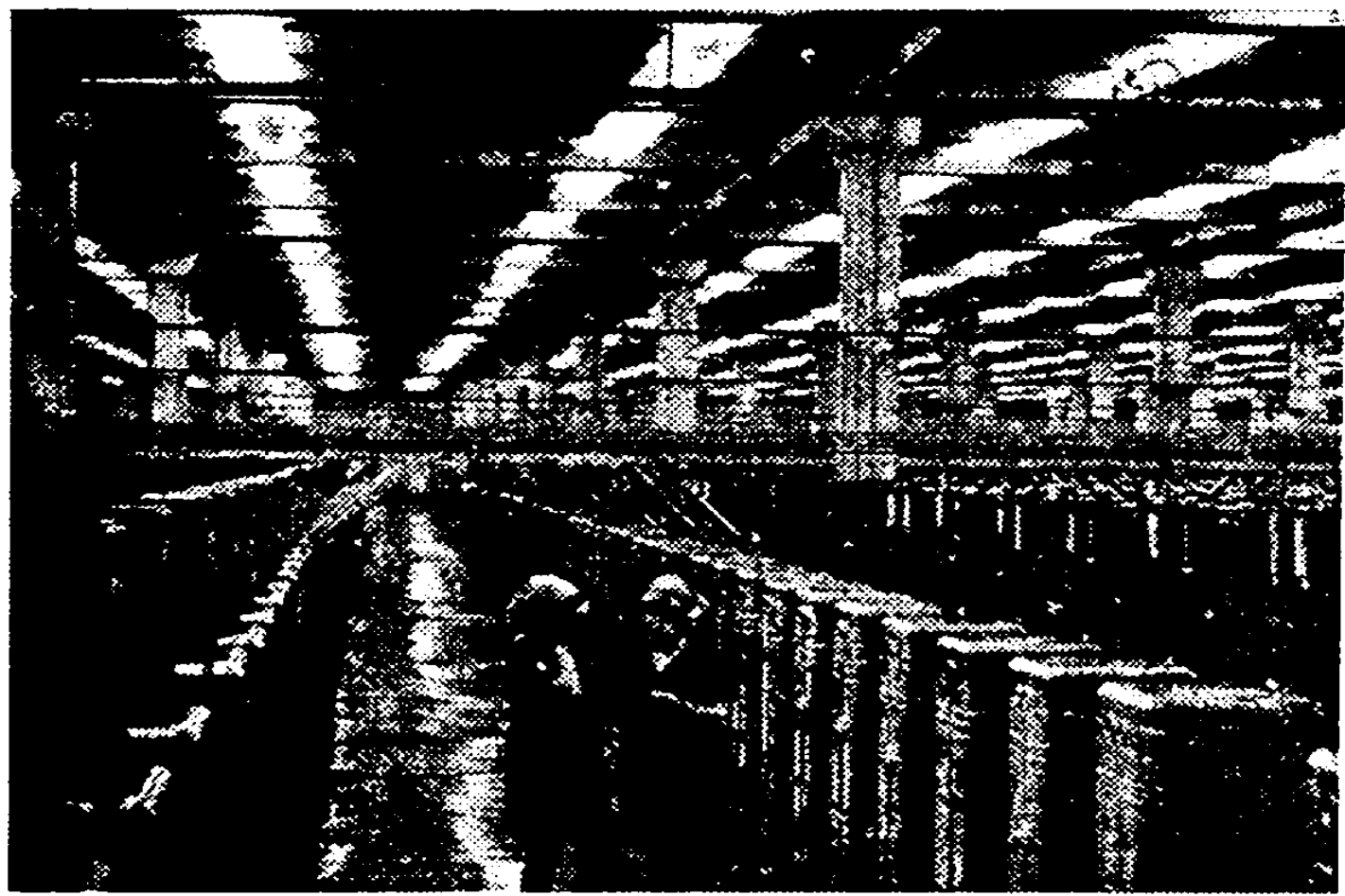

Illustration 51. Spinners. Source: URJa 1973, 2:59. Photographer unknown. 
1 гснцину иoman

2 мухчи่на man

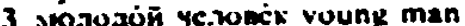

4 iceyitika pirt (in tice late tosns)

5 мi.งเunx boy

6 , jёвчка (smull) girl
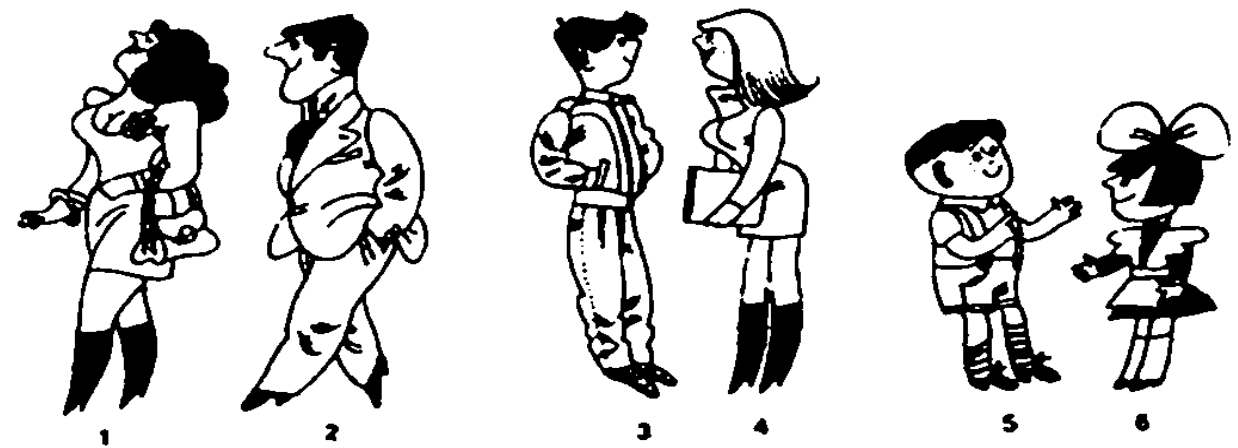

Illustration 52. Human beings. Source: RB 1999, 28. Artist: V. Karasyov.

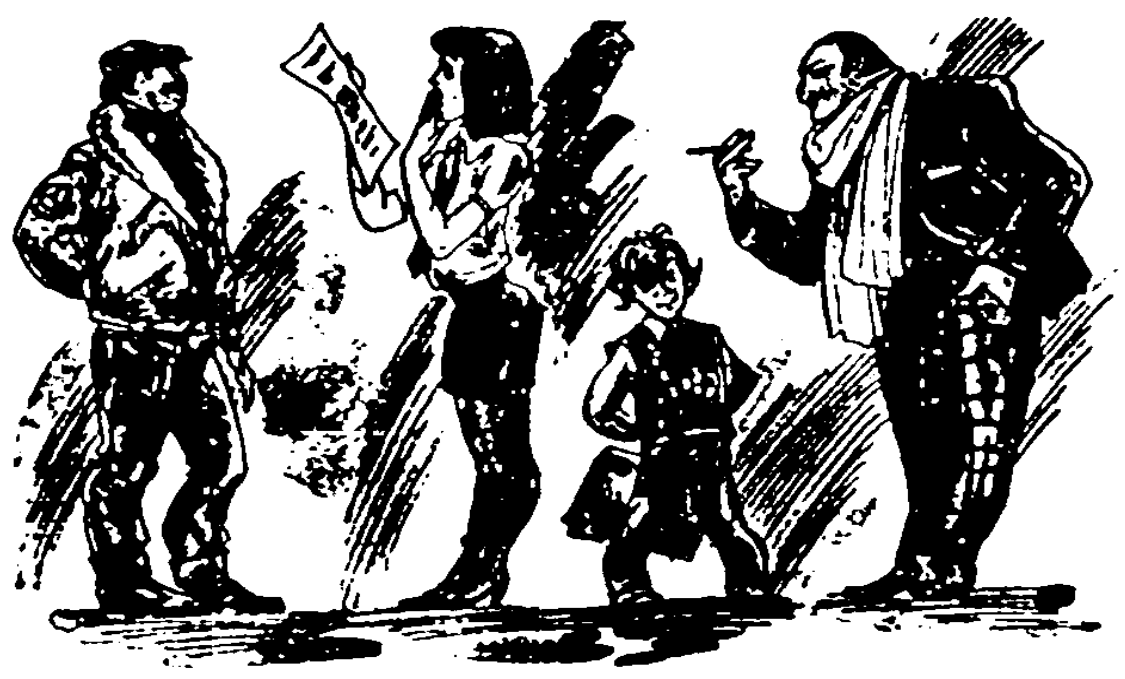

Illustration 53. Bus-driver Vova, secretary Galja, schoolboy Gleb and businessman Edik. Source: V 2 1991, 45. Artists: V. Xudjakov and I. Ćibiljaev.
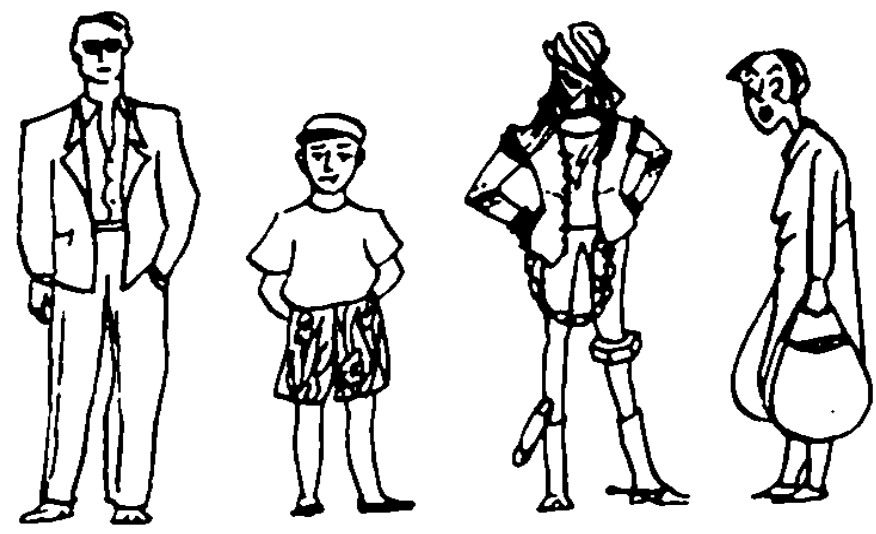

Illustration 54. 'What would be a proper gift for each of these people?' Source: RJaV 1995, 202. Artist: S. Vasil'ev. 
00055998

254

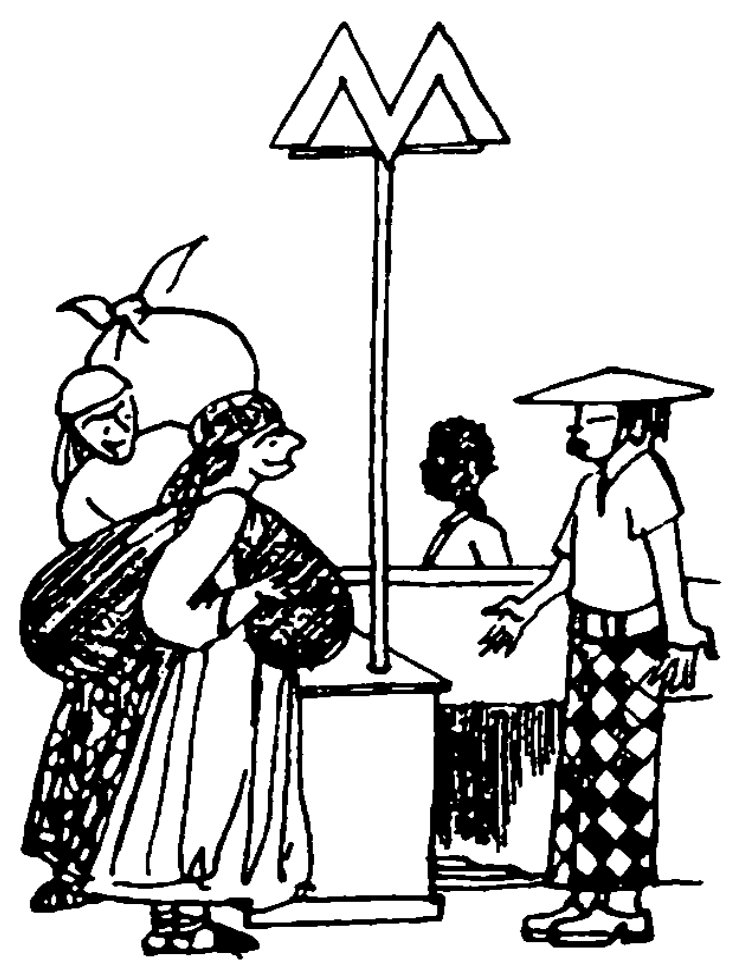

- Tor solace G.nuxaimar cimanusus mi'mplo?

- To4no ne crapy: 8 he MOCNinl

Illustration 55. 'Where is the nearest subway station?' 'I am not sure. 1 am from out of town.' Source: RJaV 1995, 175. Artist: S. Vasil'ev.

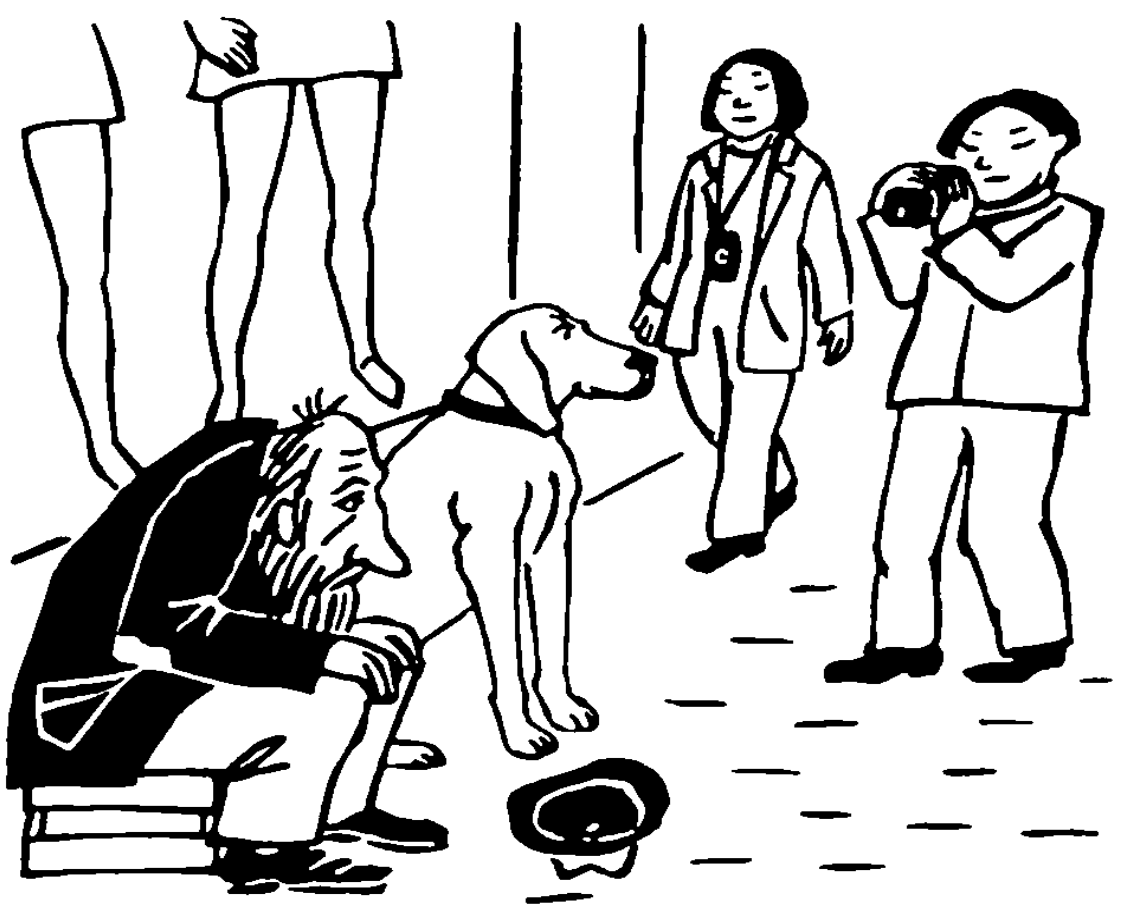

Illustration 56. The cost of living in Moscow and St. Petersburg has gone down, although not every Russian finds it easy to believe. Source: $R$ 2000, 59. Artist: $A$. N. Novikova.

Olga Mladenova - 9783954796335

Downloaded from PubFactory at 01/10/2019 02:04:08AM

via free access 


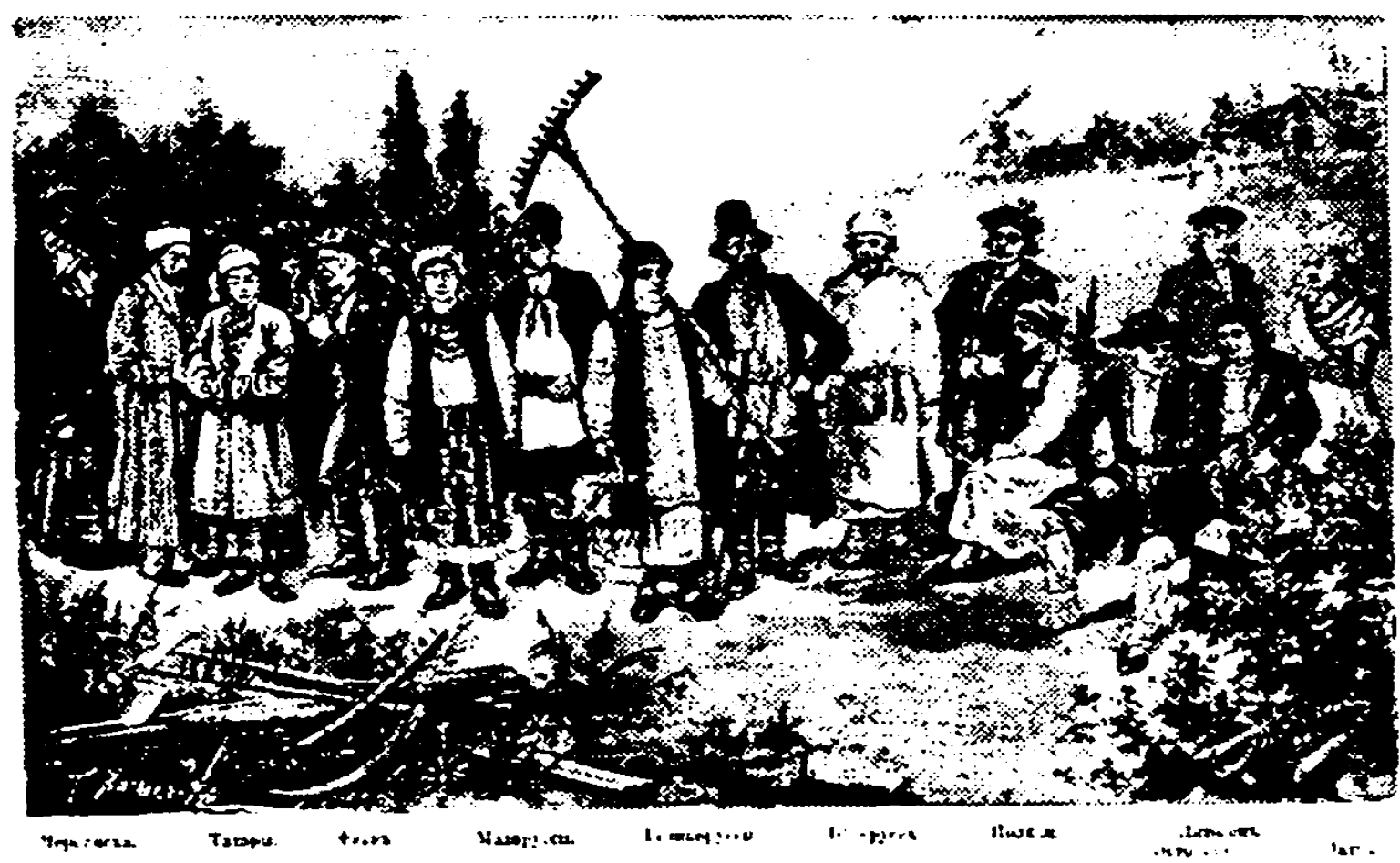

Illustration 57. Ethnic groups in the European part of Russia. Source: RS III 1907, 126. Artists: P. Visnevskij and Taburin.

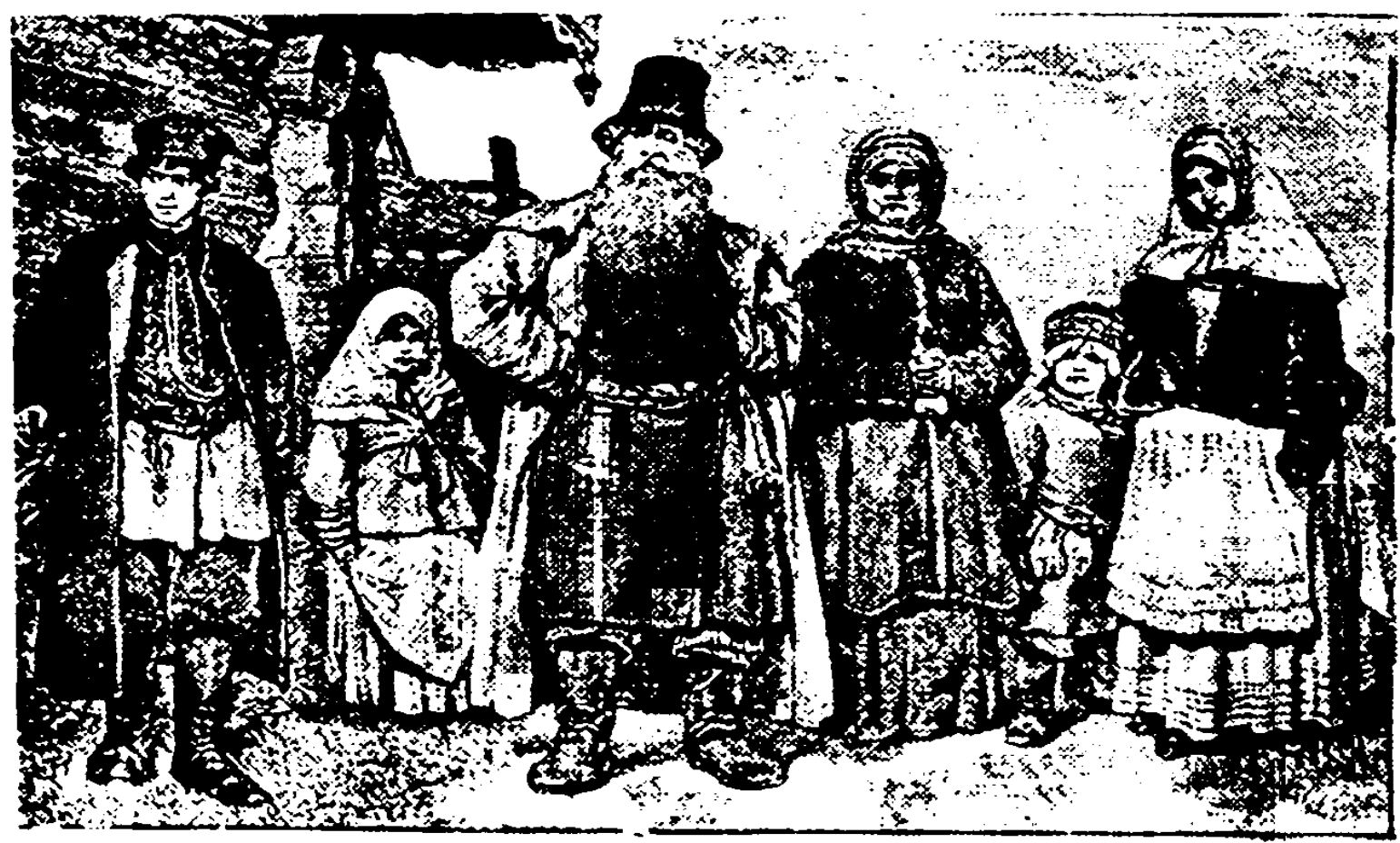

Illustration 58. Velikorussy. Vnutrennij ili Promyslennyj kraj. 'Great Russians. The Internal or the Industrial Region.' RR III 1914, 137. Artist: I. Xelmickij. 
256

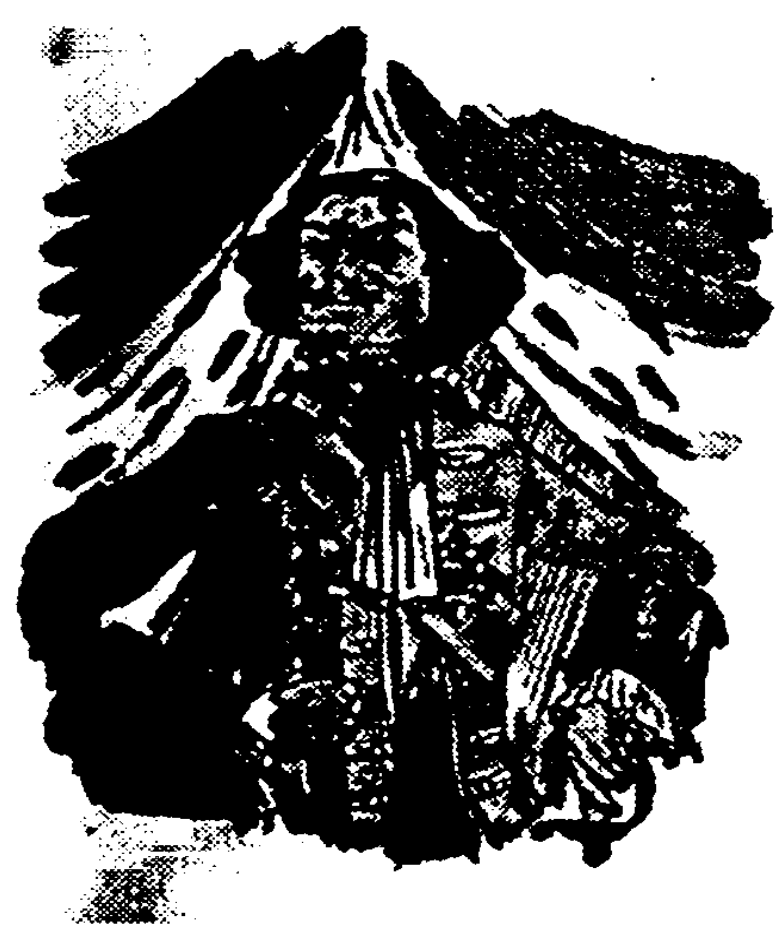

Illustration 59. Peter I. Source: V 2 1991, 29. Artists: V. Xudjakov and I. Cibiljaev.

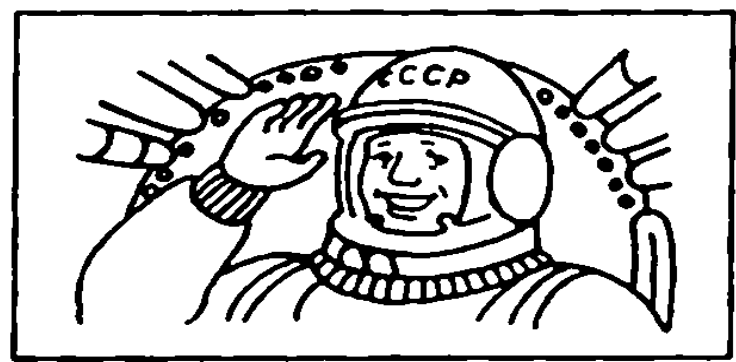

Это Юрия Гагарни. Он в космосе.

Illustration 61. 'This is Jurij Gagarin. He is in outer space.' Source: RJaV 1976, 246. Artist: V. Alekseev.

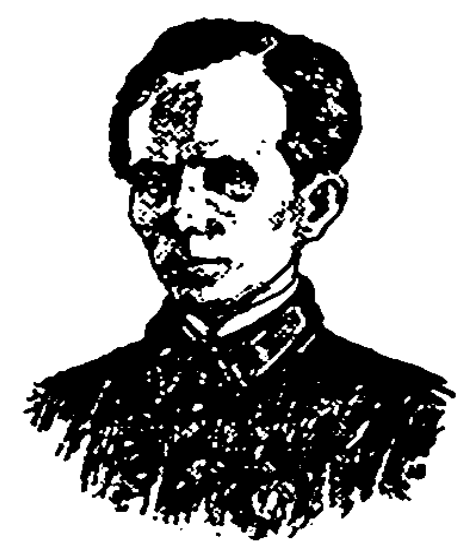

H. A. Ociponcoun (1904-1936)

Illustration 60. Proletarian writer Nikolaj

Ostrovskij. Source: URJa 1969. 2:310. Artix: I. S. Mal't.

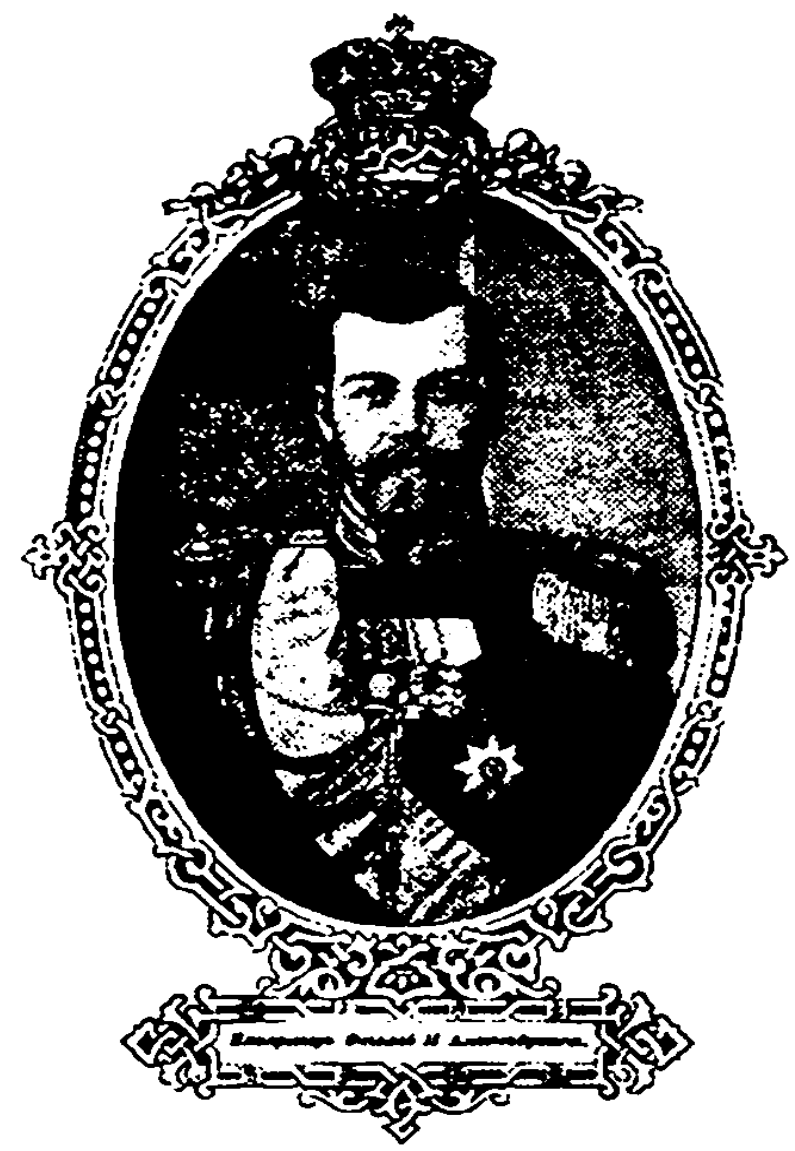

Illustration 62. Emperor Nicholas I. Source: RS III 1907, 172. Artist unknown. 

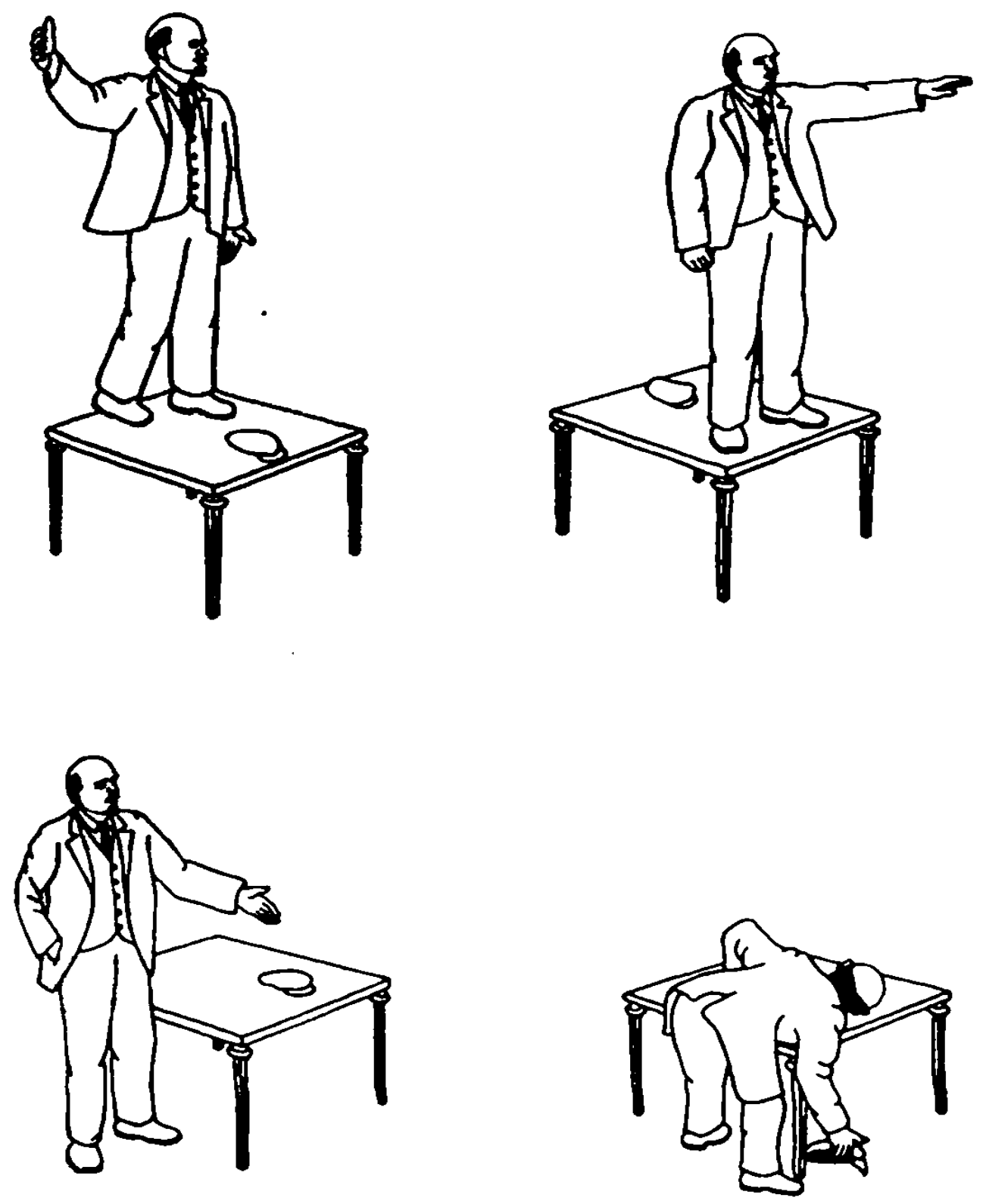

Illustration 63. Kogda Lenin prixodil na sobranie, on vstaval na stol i govoril rex'. Kepku on klal na stol rjadom s soboj. Lenin stojal na stole i govoril re ${ }^{\prime}$, a kepka ležala na stole rjadom s nim. Posle sobranlja Lenin spuskalsja so stola, bral kepku so stola i nadeval ee na golovu. Inogda Lenin klal kepku pod stol. Lenin stojal na stole i govoril rex', a kepka ležala pod stolom. No poske sobrenija Lenin po-prežnemu bral kepku izpod stola i nadeval ee na golovu

'When Lenin would come to a meeting, he would stand up on the table and deliver a speech. He would put his cap on the table by his side. After the meeting, Lenin would get off the table, take his cap from the table and put it on his head. Sometimes Lenin would put his cap under the table. Lenin would stand on the table and deliver his speech and his cap would lie under the table. But after the meeting, Lenin would as before take his cap from under the table and put it on his head.' Source: BR 1981, 307, 311. Artist unknown. 


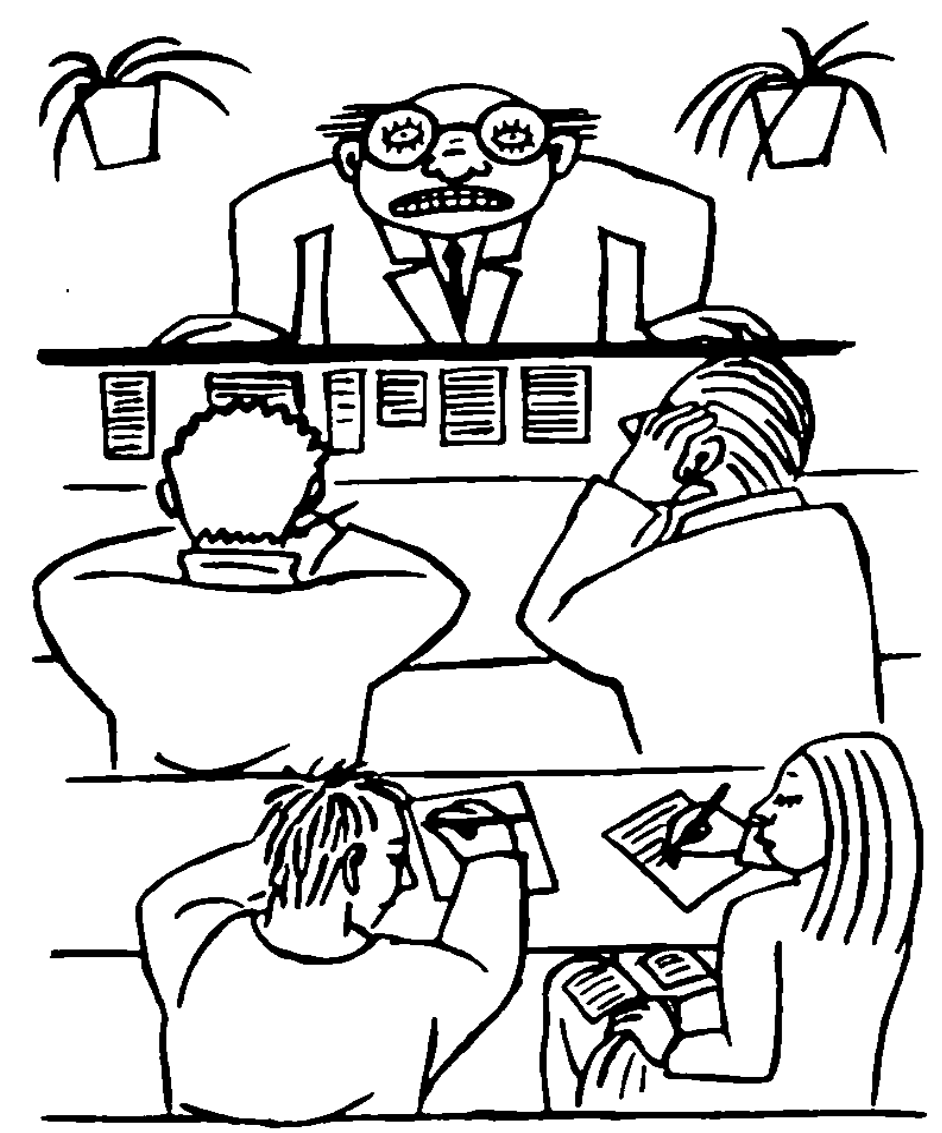

Illustration 64. Preparing for an oral exam in Russia. Source: R 2000, 117 Artist: A. N. Novikova.

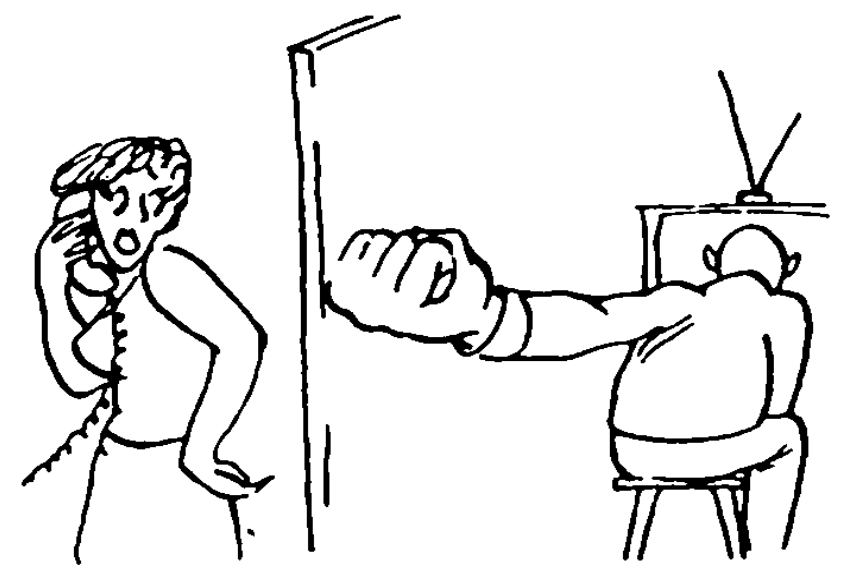

- Тебе кух помогаст по дому?

- Какос там помогаетl Придёт с раболиı,.

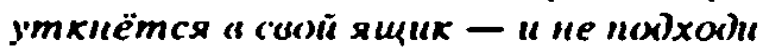

Illustration 65. 'Does your husband help you with the household chores?' 'No way. He comes from work, sits down in front of the TV and it's better not to come near him if you don't want trouble.' Source: RJaV 1995, 243. Artist: S. Vasil'ev. 
1) ванна, закрыт, занят, стучать, толкать, пускать кораблики
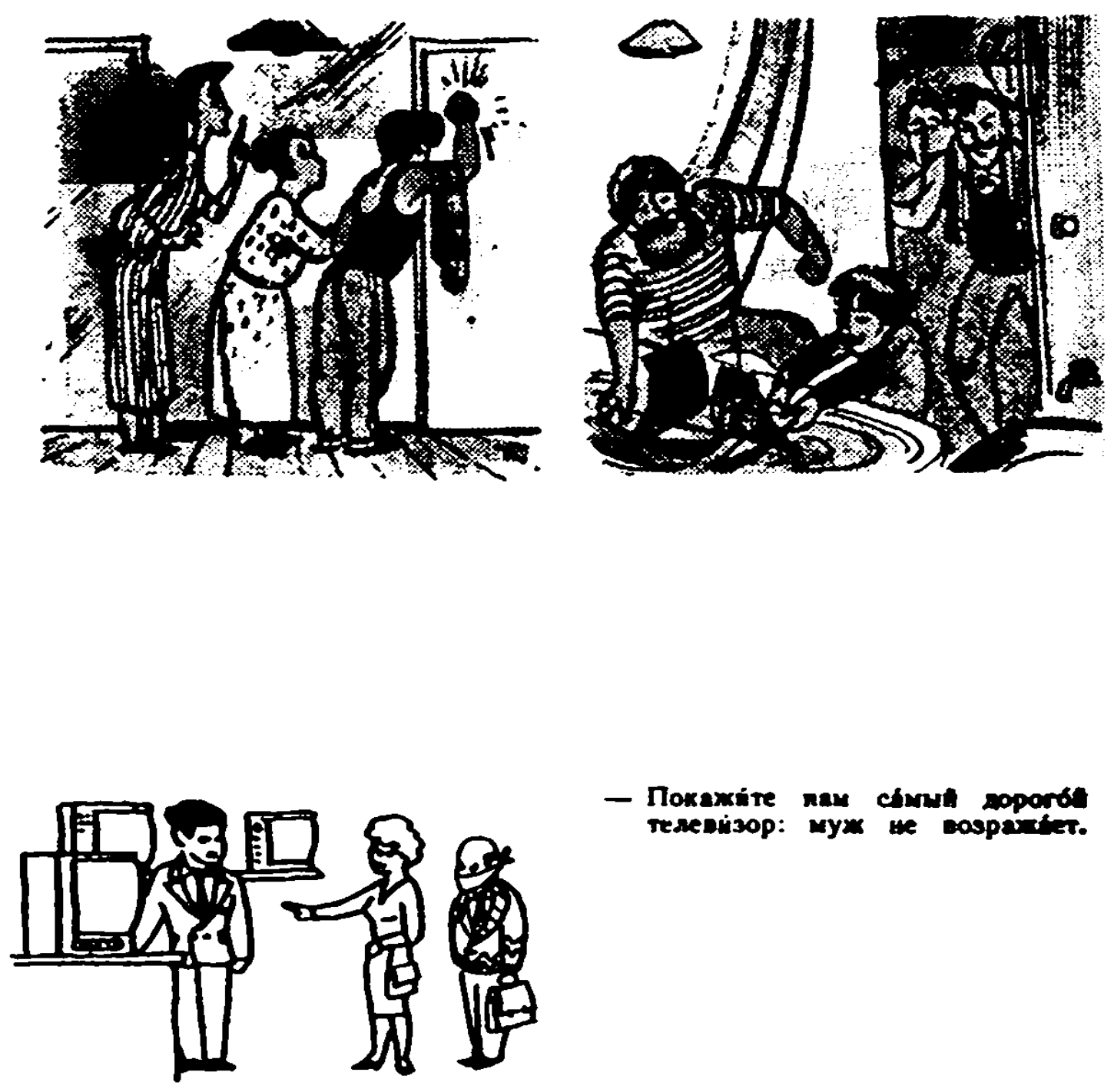

- Пoxamite nan chmul soporot телепізор: муш ие оospritit.

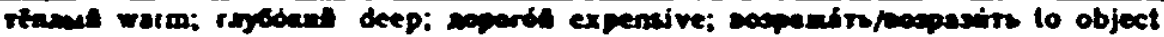




\section{Die Welt Der Slaven}

\section{Sammelbände • Сборники}

Herausgegeben von Peter Rehder und Igor Smirnov - Verlag Otto Sagner, D-80328 München

Bd. 2/4/8/12/15/20: Beiträge der Europäischen Slavistischen Linguistik (Polyslav). Herausgegeben von K. Böttger, S. Dönninghaus, M. Giger, R. Marzari, B. Wiemer.

Bd. I: 1998. Hardcover. X. 212 S. $43.97 €$. (ISBN 3-87690-705-5)

Bd. 2: 1999. Hardcover. VIII. 320 S. $57.26 €$. (ISBN 3-87690-738-1)

Bd. 3: 2000. Hardcover. X. 232 S. 48.06 E. (ISBN 3-87690-773-X)

Bd. 4: 2001. Hardcover. VIII. 292 S. 50.1I $\in$. (ISBN 3-87690-803-5)

Bd. S: 2002. Hardcover. X. 303 S. 54.00 €. (ISBN 3-87690-825-6)

Bd. 6: 2003. Hardcover. X. 281 S. 53.00 Є. (ISBN 3-87690-852-3)

Bd. 5: Festschrift für Klaus Trost zum 65. Geburtstag. Herausgegeben von Ernst Hansack, Walter Koschmal. Norbert Nübler, Radoslav Večerka.

1999. Hardcover. 355 S. 61.36 €. (ISBN 3.87690-739-X)

Bd. 6: Poetik der Metadiskursivität. Zum postmodernen Prosa-, Film- und Dramenwerk von Vladimir Sorokin. Herausgegeben von Dagmar Burkhart.

1999. Hardcover. 244 S. $49.08 \in$. (ISBN 3-87690-745-4)

Bd. 7: Kapitel zur Poetik Karel Hynek Máchas. Die tschechische Romantik im europäischen Kontext. Beiträge zum Internationalen Bohemistischen Mácha-Symposium an der Universität Potsdam 21.-22.1.1995. Herausgegeben von Herta Schmid in Zusammenarbeit mit dem Ústav pro čcskou literaturu Akademie Věd České Republiky und unter Mitwirkung von Holt Meyer und Irina Wutsdorff.

2000. Hardcover. 307 S. 61.36 €. (ISBN 3-87690-756-X)

Bd. 9: Hypertext Omчаяние / Сверхтекст Despair. Studien zu Vladimir Nabokovs Roman-Rätsel.

Herausgegeben von Igor Smirnov. Internetredaktion: Harty Raiser. Natalja Sander, Lora Schlothauer.

2000. Hardcover. 279 S. 50.1I $\in$. (ISBN 3-87690-777-2)

Bd. 10: Entgrenzte Repräsentationen // Gebrochene Realitäten. Danilo Kiš im Spannungsfeld von Ethik, Literatur und Politik. Herausgegeben von Angela Richter unter Mitwirkung von Tatjana Petzer. 200I. Hardcover. 226 S. $38.86 \in$. (ISBN 3-87690-783-7)

Bd. 11: Количественность и градуальность в естественном языке. Quantität und Graduierung in der natürlichen Sprache. Herausgegeben von Alexander Kiklcvič.

2001. Hardcover. VIII. 212 S. 34.77 €. (ISBN 3-87690-782-9)

Bd. 13: Gedächtnis und Phantasma. Festschrift für Renate Lachmann. Herausgegeben von Susi K. Frank, Erika Greber, Schamma Schahadat, Igor Smirnov.

2001. Hardcover. 634 S. 130.- €. (ISBN 3-87690-820-5)

Bd. 14: Lexical Norm and National Language. Lexicography and Language Policy in South-Slavic Languages after 1989. Herausgegeben von Radovan Lučić.

2002. Hardcover. 192 S. 36.- $€$. (ISBN 3-8769)-823-1)

Bd. 16: Itinera Slavica. Studien zu Literatur und Kultur der Slaven. Festschrift für Rolf-Dietea Kluge zum 65. Geburtstag. Herausgegeben von Heide Willich-Lederbogen. Regine Nohejl. Michach Fischer, Heinz Setzer.

2002. Hardcover. 308 S. 60.- $€$. (ISBN 3-8769)-824-8)

Bd. 17: Bühne und Öffentlichkeit. Drama und Theater im Spät- und Postsozialismus (1983-1993) Herausgegeben von Norbert Franz und Herta Schmid.

2002. Hardcover. 200 S. 46.- $€$. (ISBN 3-87690-833-7)

Bd. 18: Kapitel zur Poetik: Vrchlický und der tschechische Symbolismus. Beiträge zum Interna tionalen Bohemistischen Vrchlický-Synposium an der Universität Potsdam 4. bis 7. Dezember 1997. Herausgegeben von Herta Schmid unter Mitwirkung von Birgit Krehl und Irina Wutsdorff.

2003. Hardcover. 270 S. 54.- $€$. (ISBN 3-87690-834-5)

Bd. 19: Русистика - Славистика - Липгвистика. Festschrift für Werner Lehfeldt zum 60. (ie burtstag. Herausgegeben von Sebastian Kempgen. Ulrich Schweier. Tilman Berger.

2003. Hardcover. 532 S. 90.- $\epsilon$. (ISIBN 3-87690)-837-5) 


\section{Slavistische Beiträge}

Herausgegeben von Peter Rehder

388. Poljakov, Fedor B., Carmen Sippl: A. S. Puškin im Übersetzungswerk Henry von Heiselers (1875-1928). Ein europäischer Wirkungsraum der Petersburger Kultur. 1999. 131 S. $18.41 €$. (3-87690-753-5)

389. Betsch, Michael: Diskontinuität und Tradition im System der tschechischen Anredepronomina (1700-1850). 2000. 198 S. $21.47 \in .(3-87690-754-3)$

390. Brinkjost, Ulrike: Geschichte und Geschichten. Ästhetischer und historiographischer Diskurs bei N. M. Karamzin. 2000. 225 S. $23.52 €$. (3-87690-755-1)

391. Rajewsky, Alice: Changes in the Russian Terminology of Economic Law Since Perestroika. 2000. 208 S. $22.50 €$. (3-87690-757-8)

392. Rybakov, Alexei: Deutsche und russische Literatur an der Schwelle zur Moderne. „Wilhem Meisters Lehrjahre“ und „Eugen Onegin“. Zur Entstehung des modernen Weltbildes. 2000. 251 S. 24.54 €. (3-87690-763-2)

393. Guławska, Małgorzata: Aspektualität im Polnischen und Deutschen. Eine praktische Untersuchung am Beispiel der Übersetzungen beider Richtungen. 2000 . 219 S. 23.52 €. (3-87690764-0)

394. Кондратенко, Миханл: Лексика народной метеорологии. Опыт сравнительного анализа славянских и немецких наименований природных явлений. 2000. $117 \mathrm{~S}$. 17.38 є. (387690-765-9)

395. Ylli, Xhelal: Das slavische Lehngut im Albanischen. 2. Teil: Ortsnamen. 2000. 280 S. $24.54 €$. (3-87690-772-1) - [1. Teil: Lehnwörter, siche SB 350, 1997.]

396. Slavistische Linguistik 1999. Referate des XXV. Konstanzer Slavistischen Arbeitstreffens, Konstanz 7.-10.9.1999. Herausgegeben von Walter Breu. 2000. 314 S. 29.65 €. (3-87690774-8)

397. Сологу6, Федор: Двенадцать драм. Составитель Ульрих Нтельтнер. 2000. VIII, 366 S. 29.65 є. (3-87690-775-6) - [1. + 2. Bd.: SB 291 (1992) + 343 (1997).]

398. Drews, Peter: Deutsch-polnische Literaturbeziehungen 1800-1850. 2000. 296 S. 24.54 €. (387690-776-4)

399. Poljakov, Fedor B., Carmen Sippl: Dramen der russischen Moderne in unbekannten Übersetzungen Henry von Heiselers. 2000. $161 \mathrm{~S} .19 .43 €$. (3-87690-778-0)

4(0). Patzke, Una: Antonymische Relationen im Text. Zur Neubestimmung einer Kategorie unter funktional-kommunikativem Aspekt. 2000. 276 S. 24.54 €. (3-87690-779-9)

401. Notarp, Ulrike: Der Russische Interdiskurs und seine Entwicklung. Eine kultur- und diskurstheoretische Analyse am Material von Schulbuichern (1986-1991 und 1993-1997). 2001.621 S. $34.77 \epsilon .(3-87690-780-2)$

402. Soldat, Comelia: Urbild und Abbild. Untersuchungen zu Herrschaft und Weltbild in AltruBland, 11.-16. Jahrhundert. 2001. 265 S. 24.54 €. (3-87690-81-0)

403. Vintr, Josef: Das Tschechische. Hauptzüge seiner Sprachstruktur in Gegenwart und Geschichte. 2001. 240 S. $20.45 €$. (3-87690-796-9) (= Studienhilfen. 11.)

404. Becker, Joem-Martin: Semantische Variabilität der russischen politischen Lexik im zwanzigsten Jahrhundert. 2001. 3000 S. $24.54 €$. (3-87690-797-7)

405. Reinkowski, Ljiljana: Syntaktischer Wandel im Kroatischen am Beispiel der Enklitika. 2001. 319 S. 24.54 €. (3-87690-798-5)

406. Kolchinsky, Irene: The Revival of the Russian Avant-Garde: the Thaw Generation and Beyond. 2001. 206 S. $23.52 \in$. (3-87690-799-3)

407. Lange, Katrin: Die Glossolalie der Liebe. Geschlechterverhältnisse und Liebesdiskurse in den Texten Valerija Narbokovas. 2001. 204 S. 23.52 €. (3-87690-805-1)

408. Huterer, Andrea: Dic Wortbildungslehre in der Anweisung aur Erlermung der SlavomischRußischen Sprache (1705-1729) von Johann Werner Paus. 20()1. 327 S. 26.59 є. (3-87690805-1)

409. Vickery, Walter N.: M. lu. Lermontov: His Life and Work. 200)I. VIII. +22 S. $29.65 \in$ (.387690-813-2)

410. Slavistische Linguistik 2000. Referate des XXVI. Konstanzer Slavistischen Arbeitstreffens. Hamburg 26.-28.9.2000. Herausgegeben von Volkmar Lehmann und Jessica Scharnberg. 2001.277 S. 26.59 є. (3-87690-814-0) 
411. Berwanger, Katrin: Die szenische Poetik Božena Nexmcovás. Theatralische Medialität in ihren Briefen, Reiseskizzen und Erzählwerken. 2001. 201 S. $23.52 €$ (3-87690-815-9)

412. Swiderska, Małgorzata: Studien zur literaturwissenschaftlichen Imagologie. Das literarische Werk F.M. Dostoevskijs aus imagologischer Sicht mit besonderer Berücksichtigung der Darstellung Polens. 2001. 495 S. 29.65 €. (3-87690-816-7)

413. Widera, Steffi: Richard Weiner. Identität und Polarität im Prosafrühwerk. 2001. 296 S. 26.- $€$. (3-87690-818-3)

414. Szucsich, Luka: Nominale Adverbiale im Russischen. Syntax. Semantik und Informationsstruktur. 2002. 255 S. 24.- €. (3-87690-819-1)

415. Breuer, Astrid Yvonne: Asyndese? Zum Problem einer 'negativen' Kategorie. 2002. 291 S. 26.- $€$. $(3-87690-822-1)$

416. Townsend, Charles E., Laura A. Janda: Gemeinslavisch und Slavisch im Vergleich. Einführung in die Entwicklung von Phonologie und Flexion vom Frühurslavischen über das Spätgemeinslavische bis in die slavischen Einzelsprachen. Übersetzung und Redaktion Peter Rehder. Durchges. Nachdruck 2003 der 1. Aufl. 2002. 237 S. $10 €$. (3-87690-831-0)

417. Stegherr, Marc: Das Russinische. Kulturhistorische und soziolinguistische Aspekte. 2003. XII, 529 S. 58.- €. (3-87690-832-9)

418. Bayer, Lenka: Sprachgebrauch vs. Spracheinstellung im Tschechischen. Eine empirische und soziolinguistische Untersuchung in Westböhmen und Prag. 2003. 328 S. 26.- $€$. (3-87690-838-8)

419. Shull, Sarah: The Experience of Space. The Privileged Role of Spatial Prefixation in Czech and Russian. 2003. X, 239 S. 24.- $€$. (3-87690-839-6)

420. Hurtig, Claudia. Taccjana Ramza: Belarussische Grammatik in Tabellen und Übunbgen. Беларуска траматыка у табліцах и прахтыкаваннях. 2003. 267 S. 20.- є. (3-87690-850-7)

421. Belyavski-Frank, Masha: The Balkan Conditional in South Slavic. A Semantic and Syntactic Study. 2003. IV, X, 310 S. 26.- €. (3-87690-851-5)

422. Slavistische Linguistik 2001. Referate des XXVII. Konstanzer Slavistischen Arbeitstreffens, Frankfurt/Friedrichsdorf 11.-13.9.2001. Herausgegeben von Holger Kuße. 2003. 359 S. 28.€. (3-87690-853-1)

423. Böhler, Claudia: Das russisch-deutsche Wörterbuch von Iwan Pawlowsky - eine metalexikographische Analyse. 2003. X, 208 S. 24.- $\epsilon$. (3-87690-854-6)

424. Reese, Hella: Ein Meisterwerk im Zwielicht: Ivan Bunins narrative Kurzprosaverknüpfung Temnye allei zwischen Akzeptanz und Ablehnung - eine Genrestudie. 2003. 411 S. 30.- €. (3$87690-870-1$ )

425. Deschler, Jean-Paul: Kleines Wörterbuch der kirchenslavischen Sprache. Wortschatz der gebräuchlichsten liturgischen Texte mit deutscher Übersetzung. 2003. 347 S. 28.- $€$. (3-8769087I-X)

426. Waszink, Paul: Don't Weep a Gold Chain. Observations on Primary and Secondary Systems in Russian Classical and Romantic Art and Literature. 2003. X, 309 S., 15 Abb. 28.- $€$. (3. 87690-872-0)

427. 427. Schorlemmer, Uta: Die Magic der Annäherung und das Geheimnis der Distanz. Krystian Lupas Recherche »neuer Mythen« im Theater. 2003. X. 265 S., 10 Abb. 26.- €. (3-87690-8736)

428. Smola, Klavdia: Formen und Funktionen der Intertextualität im Prosawerk von Anton Čechov. 2004. 235 S. 24.- $\epsilon$. (3-87690-877-9)

429. Eberharter, Markus: Der poetische Formismus Tytus Czyżewskis. Ein literarischer Ansatz der frühen polnischen Avantgarde und sein mitteleuropaiischer Kontext. 2004. 243 S. 24.- €. (387690-878-7)

430. Tomelleri, Vittorio Springfield: Il Salterio commentato di Brunone di Würzburg in area slavoorientalc. Fra traduzione e tradizione. Con un appendice di testi. 2004. XVIII, 343 S. 28.- $€$. (387690-879-5)

431. Cehak, Meta: Formen des Autobiographischen bei Andrej Sinjavskij (Abram Terc). Golos iz chora, Kroška Cores und Spokojnoj noči. 2004. 252 S. 24.- €. (3-8769)-880-9)

432. Mladenova, Olga: Russian Second-Language Textbooks and Identity in the Universe of Discourse. A Contribution to Macropragmatics. 2004. X. 259 S. 25.- €. (3-87690-881-7)

\section{Verlag Otto Sagner • D-80328 München}

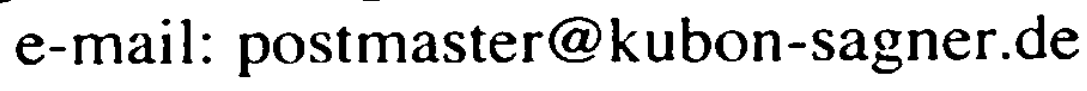

Bayerische Olga Mladenova-9783954796335

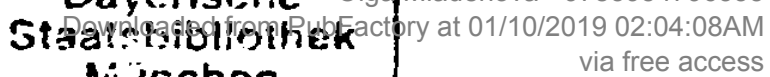

